
Digital de Imágenes para la Estimación de las Necesidades Hídricas de Lechuga (Lactuca sativa L.) en el Sureste Español

David Escarabajal Henarejos 

UNIVERSIDAD POLITÉCNICA DE CARTAGENA

Departamento de Ingeniería de Alimentos y del Equipamiento Agrícola

\title{
Aplicación de Técnicas de Tratamiento Digital de Imágenes para la Estimación de las Necesidades Hídricas de Lechuga (Lactuca sativa L.) en el Sureste Español
}

\section{Tesis Doctoral}

\author{
presentada por \\ David Escarabajal Henarejos, \\ Ingeniero Agrónomo, para optar al Grado de Doctor \\ por la Universidad Politécnica de Cartagena
}

dirigida por

Dr. José Miguel Molina Martínez

Dpto. de Ingeniería de Alimentos y del Equipamiento Agrícola

Universidad Politécnica de Cartagena codirigida por

Dr. Antonio Ruiz Canales

Dpto. de Ingeniería

Universidad Miguel Hernández de Elche 

Esta Tesis Doctoral se presenta en la modalidad de compendio de publicaciones. Los artículos que constituyen la tesis son los siguientes:

- Publicación 1: Escarabajal-Henarejos, D., Fernández-Pacheco, D.G., MolinaMartínez, J.M., Martínez-Molina, L., Ruiz-Canales, A., 2014. Selection of device to determine temperature gradients for estimating evapotranspiration using energy balance method. Agricultural Water Management; In press.

- Publicación 2: Fernández-Pacheco, D.G., Escarabajal-Henarejos, D., RuizCanales, A., Conesa, J., Molina-Martínez, J.M., 2014. A digital image-processingbased method for determining the crop coefficient of lettuce crops in the southeast of Spain. Biosystems Engineering; 117, 23 - 34.

- Publicación 3: Escarabajal-Henarejos, D., Molina-Martínez, J.M., FernándezPacheco, D.G., Cavas-Martínez, F., García-Mateos, G., 2014. Digital photography applied to irrigation management of Little Gem lettuce. Agricultural Water Management; In press.

- Publicación 4: Escarabajal-Henarejos, D., Molina-Martínez, J.M., FernándezPacheco, D.G., García-Mateos, G., 2014. Methodology for obtaining prediction models of the root depth of lettuce for its application in irrigation automation. Agricultural Water Management; In press.

- Publicación 5: García-Mateos, G., Hernández-Hernández, J.L., EscarabajalHenarejos, D., Jaén-Terrones, S., Molina-Martínez, J.M., 2014. Study and comparison of color models for automatic image analysis in irrigation management applications. Agricultural Water Management; In press. 



\section{Universidad}

Politécnica

de Cartagena

\section{CONFORMIDAD DE SOLICITUD DE AUTORIZACIÓN DE DEPÓSITO DE TESIS DOCTORAL POR EL DIRECTOR DE LA TESIS}

D. José Miguel Molina Martínez, Director de la Tesis Doctoral “Aplicación de Técnicas de Tratamiento Digital de Imágenes para la Estimación de las Necesidades Hídricas de Lechuga (Lactuca sativa L.) en el Sureste Español”.

\section{INFORMA:}

Que la referida Tesis Doctoral, ha sido realizada por D. David Escarabajal Henarejos, dentro del programa de doctorado "Técnicas Avanzadas en Investigación y Desarrollo Agrario y Alimentario", dando mi conformidad para que sea presentada ante la Comisión de Doctorado para ser autorizado su depósito.

La rama de conocimiento en la que esta tesis ha sido desarrollada es:

Ciencias

Ciencias Sociales y Jurídicas

$\bowtie$ Ingeniería y Arquitectura

En Cartagena, a 20 de octubre de 2014

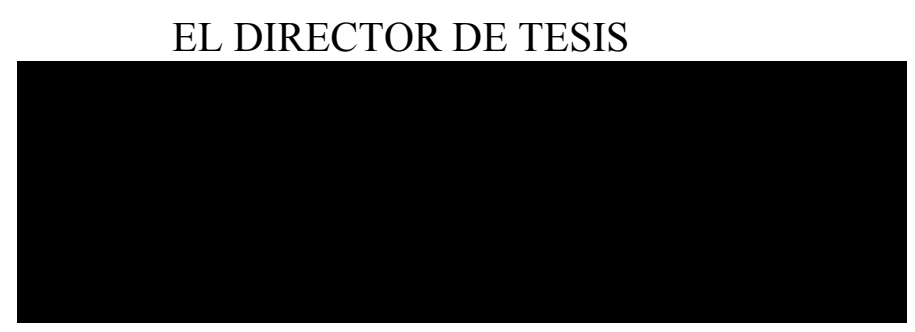

Fdo.: José Miguel Molina Martínez 



\section{CONFORMIDAD DE SOLICITUD DE AUTORIZACIÓN DE DEPÓSITO DE TESIS DOCTORAL POR EL CODIRECTOR DE LA TESIS}

D. Antonio Ruiz Canales, Codirector de la Tesis Doctoral “Aplicación de Técnicas de Tratamiento Digital de Imágenes para la Estimación de las Necesidades Hídricas de Lechuga (Lactuca sativa L.) en el Sureste Español”.

\section{INFORMA:}

Que la referida Tesis Doctoral, ha sido realizada por D. David Escarabajal Henarejos, dentro del programa de doctorado “Técnicas Avanzadas en Investigación y Desarrollo Agrario y Alimentario", dando mi conformidad para que sea presentada ante la Comisión de Doctorado para ser autorizado su depósito.

La rama de conocimiento en la que esta tesis ha sido desarrollada es:

Ciencias

$\square$ Ciencias Sociales y Jurídicas

\ Ingeniería y Arquitectura

En Cartagena, a 20 de octubre de 2014

EL CODIRECTOR DE TESIS

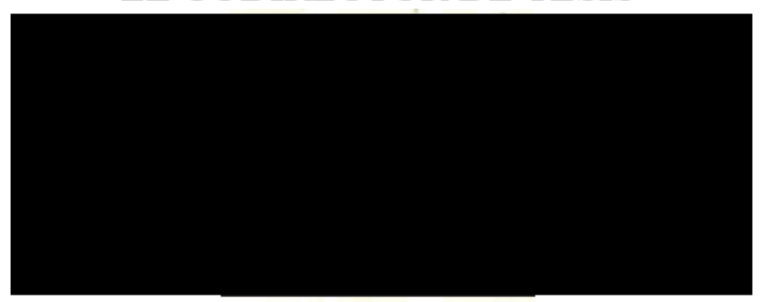

Fdo.: Antonio Ruiz Canales 



\section{Universidad}

Politécnica

de Cartagena

\section{CONFORMIDAD DE DEPÓSITO DE TESIS DOCTORAL POR LA COMISIÓN ACADÉMICA DEL PROGRAMA}

D. Francisco Artés Hernández, Presidente de la Comisión Académica del Programa "Téenicas Avanzadas en Investigación y Desarrollo Agrario y Alimentario".

\section{INFORMA:}

Que la Tesis Doctoral titulada “Aplicación de Técnicas de Tratamiento Digital de Imágenes para la Estimación de las Necesidades Hídricas de Lechuga (Lactuca sativa L.) en el Sureste Español", ha sido realizada, dentro del mencionado programa de doctorado, bajo la dirección y supervisión del Dr. José Miguel Molina Martínez y Dr. Antonio Ruiz Canales.

En reunión de la Comisión Académica de fecha 10/10/2014, visto que en la misma se acreditan los indicios de calidad correspondientes y la autorización del Director de la misma, se acordó dar la conformidad, con la finalidad de que sea autorizado su depósito por la Comisión de Doctorado.

La rama de conocimiento en la que esta tesis ha sido desarrollada es:

$\square$ Ciencias

Ciencias Sociales y Jurídicas

$\otimes$ Ingeniería y Arquitectura

En Cartagena, a 20 de octubre de 2014

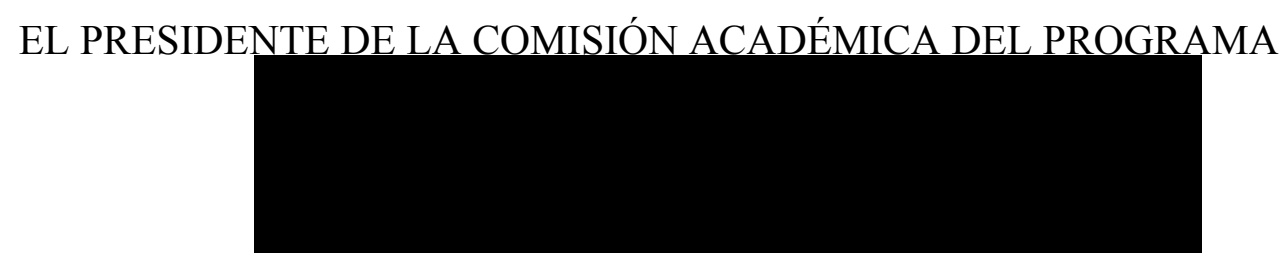

Fdo.: Francisco Artés Hernández

COMISIÓN DE DOCTORADO 

Vistos los informes favorables de los Directores de Tesis y el $\mathrm{V}^{\circ} \mathrm{B}^{\circ}$ de la Comisión Académica para la presentación de la Tesis Doctoral titulada: "Aplicación de técnicas de tratamiento digital de imágenes para la estimación de las necesidades hídricas de lechuga (Lactuca sativa $\mathbf{L}$.) en el sureste español" en la modalidad de "compendio de publicaciones" solicitada por D. David Escarabajal Henarejos, la Comisión de Doctorado de la Universidad Politécnica de Cartagena, en reunión celebrada el 28 de octubre de 2014, considerando lo dispuesto en el artículo 33 del Reglamento de Estudios Oficiales de Máster y Doctorado de la UPCT, aprobado en Consejo de Gobierno el 13 de abril de 2011 y modificado el 11 de julio de 2012,

\section{ACUERDA}

Autorizar la presentación de la Tesis Doctoral a D. David Escarabajal Henarejos en la modalidad de compendio de publicaciones.

Contra el presente acuerdo, que no agota la vía administrativa, podrá formular recurso de alzada ante el Sr. Rector-Magnífico de la Universidad Politécnica de Cartagena, en el plazo de un mes a partir de la notificación de la presente.

Cartagena, 29 de octubre de 2014

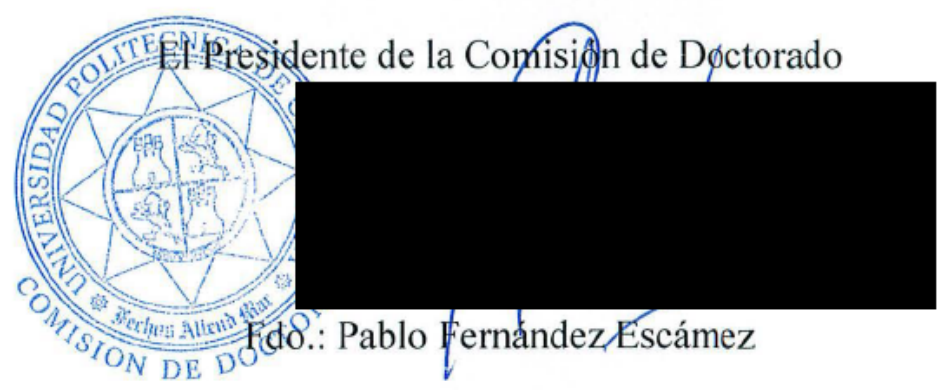





\section{Agradecimientos}

Esta Tesis Doctoral es fruto del esfuerzo y dedicación de muchas personas. Algunas han puesto a mi disposición los medios, conocimientos y tiempo necesarios; otras, ánimo y cariño y en ocasiones hasta una mano tendida para ayudarme a levantarme. Por todo ello, sirvan estas líneas para expresar mi más sincero agradecimiento a todas aquellas personas que han contribuido en el desarrollo y buen fin de esta tesis.

A los Dres. José Miguel Molina Martínez y Antonio Ruiz Canales, mis estimados directores de tesis, por brindarme la oportunidad de realizar el presente trabajo bajo su dirección, poniendo a mi disposición todos los medios humanos y materiales necesarios para llevarlo a cabo. Por sus consejos y enseñanzas, así como por su dedicación, apoyo y confianza depositada en mí desde un primer momento.

Al Dr. Daniel García Fernández-Pacheco, por encima de todo amigo y gran compañero de fatigas, por su inestimable ayuda en la elaboración, redacción y publicación de los artículos, por todas sus aportaciones y revisiones. Sin su trabajo y dedicación esta Tesis no hubiera sido una realidad, siempre será un placer trabajar contigo.

A la Fundación Séneca de la Región de Murcia, cuya financiación mediante los proyectos 08729/PI/08 y 08754/PI/08 ha permitido la realización de los trabajos de investigación enmarcados en esta Tesis Doctoral.

A las empresas Agrícola Arroyo y Marín, S.L. y Agromediterránea Hortofrutícola, S.L., por haber puesto a nuestra disposición las fincas y medios materiales necesarios para la realización de los ensayos. 
Al Instituto Técnico Agronómico Provincial (ITAP) de Albacete, y en su nombre al Dr. Ramón López Urrea, por facilitarnos de manera desinteresada el acceso a la finca Las Tiesas para la calibración de la estación Bowen. Agradecer también a Laura Martínez Molina su paciencia y dedicación para iniciarme en el manejo del software ENVI para el procesamiento digital de imágenes y por todos los datos proporcionados del lisímetro y estación agrometeorológica.

A mis grandes amigos y compañeros de la Universidad Politécnica de Cartagena, la que fue mi segunda casa durante varios años. A los componentes del Grupo de Investigación en Ingeniería Agromótica y del Mar, por tantas horas compartidas que siempre han sido placenteras. A Paco, Pedro, Pablo, María de los Ángeles, María y Esperanza, por su valiosa ayuda e impecable labor durante el periodo de adquisición y análisis de datos experimentales.

A mis amigos, por el cariño y apoyo para continuar con mis objetivos, por haber estado siempre que los he necesitado, por todos los buenos momentos vividos y por vivir, por sentirse orgullosos de mis conquistas y ayudarme a levantarme en mis derrotas, lo mejor es tenerlos y poder compartir mi vida con ellos.

A toda mi familia que, sin entender muy bien a qué me dedicaba, siempre me han arropado y animado a luchar por mis propósitos. A mis padres, que me lo han dado todo a cambio de nada, hermanos, sobrinos; y por supuesto, a toda mi querida familia política, por su constante ayuda, apoyo y preocupación por mi bienestar durante este tiempo. Y como no, a mi ahijada Berta, mi perla, a quien el tiempo le enseñará que con esfuerzo y sacrificio logrará alcanzar todas las metas que se proponga en la vida.

Y finalmente, a mi mujer, mi compañera en este proyecto de vida en común que iniciamos juntos hace años, y que tan de cerca ha vivido el proceso de realización de esta Tesis Doctoral, por su cariño, comprensión y apoyo incondicionales en todas mis andaduras, por muy disparatadas que parecieran, por sus sabios consejos y por todos los momentos robados que ha sabido llevar con paciencia y entrega, que espero poder devolverle. Por todo su amor.

A todos ellos, muchas gracias. 


\section{Producción Científica}

\section{Publicaciones Científico - Técnicas}

Escarabajal-Henarejos, D., Fernández-Pacheco, D.G., Molina-Martínez, J.M., Martínez-Molina, L., Ruiz-Canales, A., 2014. Selection of device to determine temperature gradients for estimating evapotranspiration using energy balance method. Agricultural Water Management; In press.

Fernández-Pacheco, D.G., Escarabajal-Henarejos, D., Ruiz-Canales, A., Conesa, J., Molina-Martínez, J.M., 2014. A digital image-processing-based method for determining the crop coefficient of lettuce crops in the southeast of Spain. Biosystems Engineering; 117, 23 - 34.

Escarabajal-Henarejos, D., Molina-Martínez, J.M., Fernández-Pacheco, D.G., CavasMartínez, F., García-Mateos, G., 2014. Digital photography applied to irrigation management of Little Gem lettuce. Agricultural Water Management; In press.

Escarabajal-Henarejos, D., Molina-Martínez, J.M., Fernández-Pacheco, D.G., GarcíaMateos, G., 2014. Methodology for obtaining prediction models of the root depth of lettuce for its application in irrigation automation. Agricultural Water Management; In press. 
García-Mateos, G., Hernández-Hernández, J.L., Escarabajal-Henarejos, D., JaénTerrones, S., Molina-Martínez, J.M., 2014. Study and comparison of color models for automatic image analysis in irrigation management applications. Agricultural Water Management; In press.

Escarabajal-Henarejos, D., Martínez-Garrido, P., Molina Martínez, J.M., FernándezPacheco, D.G., Ruiz-Canales, A., Martínez-Molina, L., 2012. Estudio del crecimiento de lechuga (Lactuca sativa L. cv. 'Hierro') mediante tratamiento digital de imagen. Agrícola Vergel: Fruticultura, Horticultura, Floricultura, ISSN 02112728, Año 31, No 354, 2012, págs. 63-68.

\section{Comunicaciones a Congresos}

Escarabajal-Henarejos, D., Molina-Martínez, J.M., Fernández-Pacheco, D.G., GarcíaMateos, G., Ruiz-Canales, A., 2014. Modelo de simulación del espesor de la zona radicular en lechuga (Lactuca sativa L. cv. Little Gem) para su aplicación en automatización del riego. I Symposium Nacional de Ingeniería Hortícola. La Agromótica en la Horticultura. Orihuela, España.

Escarabajal-Henarejos, D., Molina-Martínez, J.M., Fernández-Pacheco, D.G., CavasMartínez, F., García-Mateos, G., Ruiz-Canales, A., 2014. Fotografía digital y su aplicación para gestión del riego de lechuga Little Gem. Evaluación de un caso real. I Symposium Nacional de Ingeniería Hortícola. La Agromótica en la Horticultura. Orihuela, España.

García-Mateos, G., Jaén-Terrones, S., Escarabajal-Henarejos, D., HernándezHernández, J.L., Molina Martínez, J.M., 2014. Estudio y comparación de modelos de color para el análisis automático de imágenes de cultivos. I Symposium Nacional de Ingeniería Hortícola. La Agromótica en la Horticultura. Orihuela, España.

Cavas-Martínez, F., Pérez-Sánchez, C.A., Fernández-Pacheco, D.G., EscarabajalHenarejos, D., Cañavate, F.J., Nieto, J., 2014. Reconstrucción tridimensional de frutas a partir de imágenes digitales para su análisis en un entorno CAD. I Symposium Nacional de Ingeniería Hortícola. La Agromótica en la Horticultura. Orihuela, España. 
Escarabajal-Henarejos, D., Truque-Rodríguez, E., Molina-Martínez, J.M., RuizPeñalver, L., Ruiz-Canales, A., 2013. Modeling the growth of lettuce Little gem for application in irrigation management. VII Congreso Ibérico de Agroingeniería y Ciencias Hortícolas (SEAgEng-SECH 2013). Madrid, España.

Escarabajal-Henarejos, D., Truque-Rodríguez, E., Molina-Martínez, J.M., RuizPeñalver, L., Ruiz-Canales, A., 2013. Digital photography applications for agronomic solutions. VII Congreso Ibérico de Agroingeniería y Ciencias Hortícolas (SEAgEng-SECH 2013). Madrid, España.

Fernández-Pacheco, D.G., Escarabajal-Henarejos, D., López-Urrea, R., Ruiz-Canales, A., Ruiz-Peñalver, L., Molina-Martínez, J.M., 2012. Computer vision based system for growth analysis of Lactuca sativa L. cv. Hierro. International Conference of Agricultural Engineering (CIGR-AgEng2012). Valencia, España.

Fernández-Pacheco, D.G., Escarabajal-Henarejos, D., López-Urrea, R., Ruiz-Canales, A., Ruiz-Peñalver, L., Molina-Martínez, J.M., 2012. Enhancements of using RTD instead of thermocouples for estimating evapotranspiration by means of energy balance. International Conference of Agricultural Engineering (CIGRAgEng2012). Valencia, España.

Escarabajal-Henarejos, D., Martínez-Garrido, P., Molina-Martínez, J.M., FernándezPacheco, D.G., Ruiz-Canales, A., López-Urrea, R., Puerto, H., 2012. Estimación de las necesidades hídricas en colirrábano (Brassica oleracea gongylodes L.) mediante técnicas de tratamiento digital de la imagen. International Congress of Water, Waste and Energy Management. Salamanca, España.

Escarabajal-Henarejos, D., Martínez-Garrido, P., Molina-Martínez, J.M., FernándezPacheco, D.G., Puerto, H., Ruiz-Canales, A., 2012. Digital photography applied to estimate kohlrabi crop coefficients. $4^{\text {th }}$ Emuni Research Souk - The EuroMediterranean Student Reseach Multi-Conference. Murcia, España.

Escarabajal-Henarejos, D., Molina-Martínez, J.M., Fernández-Pacheco, D.G., RuizCanales, A., López-Urrea, R., 2012. Estudio comparativo del empleo de termopares y RTDs en la estimación de la evapotranspiración mediante balance de energía. XIII Congreso Nacional de Ciencias Hortícolas. Almería, España. 
Escarabajal-Henarejos, D., Molina-Martínez, J.M., Fernández-Pacheco, D.G., RuizCanales, A., 2011. Desarrollo y puesta en marcha de un equipo para la medida de la evapotranspiración real basado en la razón de Bowen. XXIX Congreso Nacional de Riegos. Córdoba, España.

Ruiz-Peñalver, L., Molina-Martínez, J.M., Escarabajal-Henarejos, D., Ruiz-Canales, A., 2011. Utilización de metodología CAD para interpolación de datos. XXIX Congreso Nacional de Riegos. Córdoba, España.

\section{Proyectos Fin de Carrera}

Martínez Garrido, P., 2012. Estimación del coeficiente de cultivo mediante la altura de la planta y fracción de cobertura del suelo determinada por fotografía digital. Proyecto Fin de Carrera. Escuela Técnica Superior de Ingeniería Agronómica. Universidad Politécnica de Cartagena.

Crespo Ródenas, P., 2012. Determinación de algoritmos de gestión de riego en Lactuca sativa L. a partir de imágenes digitales. Proyecto Fin de Carrera. Escuela Técnica Superior de Ingeniería Agronómica. Universidad Politécnica de Cartagena.

\section{Premios y Menciones}

Escarabajal-Henarejos, D., Truque-Rodríguez, E., Molina-Martínez, J.M., RuizPeñalver, L., Ruiz-Canales, A., 2013. Digital photography applications for agronomic solutions. VII Congreso Ibérico de Agroingeniería y Ciencias Hortícolas (SEAgEng-SECH 2013). Madrid, España. PREMIO al mejor trabajo presentado en la sesión de Agricultura de Precisión y Tecnologías de la Información III.

Escarabajal-Henarejos, D., Molina-Martínez, J.M., Fernández-Pacheco, D.G., GarcíaMateos, G., Ruiz-Canales, A., 2014. Modelo de simulación del espesor de la zona radicular en lechuga (Lactuca sativa L. cv. Little Gem) para su aplicación en automatización del riego. I Symposium Nacional de Ingeniería Hortícola. La Agromótica en la Horticultura. Orihuela, España. MENCIÓN DE EXCELENCIA al mejor trabajo presentado en las Sesiones Técnicas III: Automatización y Control para la Gestión de Recursos Hídricos en la Horticultura. 
Escarabajal-Henarejos, D., Molina-Martínez, J.M., Fernández-Pacheco, D.G., CavasMartínez, F., García-Mateos, G., Ruiz-Canales, A., 2014. Fotografía digital y su aplicación para gestión del riego de lechuga Little Gem. Evaluación de un caso real. I Symposium Nacional de Ingeniería Hortícola. La Agromótica en la Horticultura. Orihuela, España. MENCIÓN DE EXCELENCIA al mejor trabajo presentado en las Sesiones Técnicas VI: Visión Artificial para el Control Automático de Procesos Agroalimentarios. 

A mis padres

A Ana 



\section{Índice}

$\begin{array}{ll}\text { Resumen } & 1\end{array}$

1. Introducción 9

2. Objetivos 13

3. Antecedentes y Estado del Arte 15

4. Publicaciones que constituyen la Tesis 21

4.1. Publicación 1. Selection of device to determine temperature gradients for estimating evapotranspiration using energy balance method

4.2. Publicación 2. A digital image-processing-based method for determining the crop coefficient of lettuce crops in the southeast of Spain

4.3. Publicación 3. Digital photography applied to irrigation management of Little Gem lettuce

4.4. Publicación 4. Methodology for obtaining prediction models of the root depth of lettuce for its application in irrigation automation

4.5. Publicación 5. Study and comparison of color models for automatic image analysis in irrigation management applications

5. Conclusiones Generales

Referencias

Apéndice I. Notificaciones de Aceptación de las Publicaciones

Apéndice II. Índices de Impacto de las Publicaciones 



\section{Resumen}

En regiones áridas y semiáridas, como el sureste español, la creciente competitividad por los recursos hídricos está causando importantes problemas de abastecimiento que afectan principalmente a la agricultura. Por tanto, uno de los objetivos prioritarios en el manejo y gestión de los recursos hídricos destinados al riego, debe ser el desarrollo e incorporación de nuevas tecnologías que permitan una mayor eficiencia del uso del agua. En este contexto, y enmarcada en el concepto agricultura de precisión, la aplicación de la fotografía digital y las diversas técnicas de tratamiento informático, en la obtención de soluciones agronómicas, constituye una herramienta de fácil y rápida aplicación tanto para la investigación como para la gestión de sistemas de riego. Además, estas técnicas se han consolidado como herramientas de precisión capaces de proporcionar información en tiempo real sobre diversos parámetros relacionados con el desarrollo y estado hídrico de los cultivos.

En este trabajo y sus líneas de investigación derivadas, se empleó la fotografía digital y las técnicas de procesamiento informático de imágenes en la estimación de los requerimientos hídricos de cultivares de lechuga (Lactuca sativa L.) localizados en la zona de explotación más extensa de este cultivo en España. Concretamente, el área de estudio comprendió cultivares situados en las provincias de Albacete y Murcia. En cuanto cifras productivas, la Región de Murcia representa la principal zona productora nacional de lechuga. 
Según la metodología FAO, la estimación de los requerimientos hídricos de los cultivos se basa en el empleo del producto de la evapotranspiración del cultivo de referencia $(E T o)$ por un coeficiente de cultivo $(K c)$ y obtener la evapotranspiración del cultivo (ETc). Para determinar este coeficiente de cultivo, específico para cada cultivo y etapa de desarrollo del mismo, se estableció como primera línea de actuación de la presente Tesis Doctoral, la calibración del método Bowen basado en los gradientes de temperatura y presión de vapor de agua para la estimación de la evapotranspiración (ETo) de un cultivo de referencia (Festuca arundinacea L. cv Scheb.). El objetivo de esta actuación fue proveer a la investigación de un sistema Bowen fiable para, posteriormente, determinar in situ y con exactitud los coeficientes $K c$ de los cultivares de lechuga ensayados, adaptados a las condiciones climáticas y técnicas de manejo del cultivo específicas de la zona. Dicha calibración se llevó a cabo en el Instituto Técnico Agronómico Provincial de Albacete (ITAP), y en ella se compararon valores de ETo, estimados por balance de energía mediante el método Bowen, con medidas de ETo mediante lisimetría de pesada. Durante el ensayo se detectó la presencia de advección de calor sensible, por lo que el método Bowen mostró una subestimación generalizada de las medidas lisimétricas de ETo.

De forma simultánea a la calibración del sistema Bowen, se desarrolló un estudio comparativo de la sensibilidad del método Bowen al empleo de diferentes sensores de medida de temperatura: termopares (TMPs) y detectores de resistencia de temperatura (RTDs). El sistema Bowen usando TMPs subestimó en torno a un 22,9\% los valores de ETo medidos por lisimetría de pesada, y el mismo sistema usando RTDs, un 21,2\%. En este caso, los RTDs denotaron una mayor similitud con los valores lisimétricos de ETo, obteniéndose un coeficiente de correlación de 0,958 en comparación con los TMPs $(0,923)$. Los resultados obtenidos sugieren la posibilidad de sustituir los TMPs instalados en las actuales estaciones Bowen por RTDs, sensores que presentan además una serie de ventajas funcionales frente a los TMPs.

La segunda línea de actuación se centró en el desarrollo y validación de una metodología operativa para determinar los coeficientes de cultivo $K c$ de lechuga a lo largo del ciclo vegetativo, a partir de fotografías digitales del dosel vegetal. Dicha metodología fue desarrollada sobre un cultivar comercial de lechuga (Lactuca sativa L. cv Hierro) y se aplicaron, a escala de marco de plantación, las técnicas de fotografía digital y diversas herramientas de procesamiento de imágenes. El desarrollo de la metodología supuso monitorizar el parámetro fracción de cobertura vegetal $(P G C)$, obtenido a partir de imágenes 
digitales de la cubierta vegetal; medir el crecimiento en altura de la planta $(h)$; y determinar in situ los coeficientes de cultivo $K c$ reales mediante el método Bowen. El método desarrollado estima en primer lugar la altura de la planta $h$ a partir del parámetro $P G C, \mathrm{y}$ obtiene el término $P G C / h$, que posteriormente se correlaciona con el coeficiente $K c$. Esto permitió obtener dos ecuaciones matemáticas con las que modelar las relaciones entre estos parámetros; determinándose coeficientes de correlación de 0,993 cuando se estimó $h$ a partir de $P G C$ y de 0,979 cuando se calculó $K c$ a partir del término $P G C / h$. Ello demuestra la validez de la metodología desarrollada.

Esta metodología desarrollada y validada fue calibrada y aplicada posteriormente sobre otra variedad de lechuga (Lactuca sativa L. cv Little Gem), también para obtener con exactitud los coeficientes $K c$ reales de dicha variedad y emplearlos en la estimación de sus requerimientos hídricos, con el fin de establecer el balance hídrico y programación del riego del cultivo. El ensayo de esta variedad queda justificado por el aumento considerable en la superficie cultivada que está experimentando esta variedad, dado el creciente interés comercial por la demanda de este tipo de lechuga para el mercado nacional y exportación. La gestión del riego llevada a cabo en base a los requerimientos hídricos estimados con los coeficientes $K c$ obtenidos por dicha metodología, se comparó con la gestión del riego basada en criterios objetivos y experiencia del propio regante, con el fin de detectar deficiencias en la gestión y cuantificar el exceso de riego. El resultado fue una reducción potencial del consumo de agua de riego del 17,80\% y un aumento potencial de la productividad de uso del agua hasta $\operatorname{los} 17,33 \mathrm{~kg} \cdot \mathrm{m}^{-3}$; en consecuencia, se obtuvieron mejores rendimientos económicos del cultivo asociados a una mayor productividad y menor consumo de agua de riego.

La programación y automatización del riego de un cultivo suele llevarse a cabo aplicando procedimientos basados en la medición del contenido de agua en el suelo. En este sentido, el balance hídrico se ha consolidado como un buen indicador del crecimiento y desarrollo de los cultivos, y es muy utilizado en la actualidad en diversos sistemas de programación automática, básicamente en cultivos intensivos y en sistemas de riego por microirrigación. El balance hídrico analiza las ganancias y pérdidas de agua en un volumen limitado de suelo, representadas principalmente por los riegos y los requerimientos hídricos del cultivo, para determinar la disponibilidad de agua para el cultivo y el estado hídrico del suelo. Un parámetro de gran importancia para la aplicación de este método es la profundidad del sistema radicular de la planta $(z)$, que permite acotar el volumen de 
suelo a considerar en dicho balance. En la mayoría de los casos, no se considera la evolución real de este parámetro durante el desarrollo del cultivo, pues se recurre a utilizar valores fijos tabulados o propuestos por la literatura científica, provocando en algunos periodos temporales de su desarrollo que el perfil de suelo considerado no se corresponda con el realmente explorado por el sistema radicular, con el consecuente desajuste en el balance hídrico.

Teniendo en cuenta este hecho, se estableció una tercera línea de actuación adicional basada en el desarrollo y validación de una metodología operativa y no destructiva para obtener modelos predictivos de la profundidad radicular del cultivo a partir del parámetro $P G C$ obtenido mediante imágenes digitales, dada la buena relación observada entre ambos parámetros. Según esta observación, se desarrolló una metodología basada en fotografía digital que permitió obtener las relaciones matemáticas entre $P G C$ y $z$ para las dos estaciones de cultivo de lechuga en esta zona, primavera y otoño, obteniéndose coeficientes de correlación de 0,997 y 0,998, demostrando la validez de la metodología desarrollada. La implantación de estas relaciones en un sistema automatizado de gestión del riego permitiría la optimización del recurso agua, debido al ajuste del contenido hídrico del suelo a la zona realmente explorada por el sistema radicular.

Finalmente y con el fin de mejorar las metodologías desarrollas y validadas en los experimentos previos, se realizó un estudio completo y exhaustivo para seleccionar el espacio de color óptimo y la forma más efectiva de representar las distribuciones de color en el proceso de segmentación automática de imágenes digitales de cubiertas vegetales para la obtención del parámetro fracción de cobertura vegetal. En el estudio se evaluó una amplia gama de espacios de color: RGB, rgb, XYZ, L*a*b*, L* $\mathrm{u}^{*} \mathrm{v}^{*}, \mathrm{HSV}, \mathrm{HLS}, \mathrm{YCrCb}$, YUV, I1I2I3 y TSL. Además, se plantearon diferentes posibilidades de modelar la probabilidad de distribución de un color dado para cada espacio. Los resultados experimentales demostraron la superioridad de los modelos que separan la luminancia de la crominancia. En concreto, el canal a* en el modelo $\mathrm{L}^{*} \mathrm{a}{ }^{*} \mathrm{~b} *$ demostró estar por encima del resto en la mayoría de los casos, con una precisión del 99,2\% por sí mismo. 


\section{Abstract}

In arid and semi-arid regions such as the southeast of Spain, increasing competitiveness for water resources is causing significant problems, mainly affecting agriculture. Therefore, one of the priority objectives in the handling and management of water resources for irrigation must be the development and incorporation of new technologies to increase the efficiency of water use. In this context, framed in precision agriculture concept, the implementation of digital photography and different computer processing techniques for obtaining agronomic solutions represents a tool of easy and quick application for both research and management irrigation systems. Furthermore, these techniques have been consolidated as precision tools capable of providing real-time information about various parameters related with developments and crop water status.

In this work and its derived research lines, digital photography and techniques of computer image processing were used to estimate water requirements of cultivars of lettuce (Lactuca sativa L.) located in the more extensive farming area of this crop in Spain. Specifically, the study area included cultivars located in the provinces of Albacete and Murcia. Regarding production figures, the Region of Murcia is the main national producer of lettuce.

According to FAO methodology, estimation of crop water requirements is based on the use of reference crop evapotranspiration (ETo) multiplied by a crop coefficient $(K c)$ and crop evapotranspiration $(E T c)$. In order to determine this crop coefficient, specific for each crop and development stage, the first action line of the present Ph.D. thesis was established as calibration of the Bowen method, based on temperature and water vapour 
pressure gradients for estimating reference crop evapotranspiration (ETo) (Festuca arundinacea L. cv Scheb.). The aim of this action was to provide a reliable Bowen system for determining location and accurately crop coefficients $K c$ of tested lettuce cultivars, adapted to climatic conditions and specific crop management techniques of the area. The calibration was carried out in the Provincial Agricultural Technical Institute of Albacete and the ETo values estimated by the Bowen Ratio - Energy Balance method (BREB) and the ETo values measured by using a weighing lysimeter were compared. During the test, a phenomenon of sensible heat advection was detected, so the BREB method showed overall underestimation of lysimetric ETo measures.

Simultaneously to the Bowen method calibration, a comparative analysis of the performance of different sensors was developed with the Bowen system: thermocouples (TMCs) and resistance temperature detectors (RTDs). The use of TMCs underestimated about $22.9 \%$ the ETo values measured by the weighing lysimeter, and the same system using RTDs, a $21.2 \%$. In this case, RTDs denoted a greater similarity to lysimetric ETo values, obtaining a squared correlation coefficient of 0.958 in comparison with TMCs (0.923). The obtained results suggest that it is possible to replace the TMCs installed in the current Bowen stations with RTDs. In addition, the use of RTDs shows several functional advantages when compared with TMCs.

The second action line is focused on the development and validation of an operational methodology for determining lettuce crop coefficients $K c$ from digital photographs of the canopy throughout growing season. This methodology was developed on a commercial lettuce cultivar (Lactuca sativa L. cv Hierro), applying digital photography techniques and various image processing tools to plantation frame scale. The development of the methodology required to monitor the percentage of green cover parameter $(P G C)$ obtained from digital photographs of the canopy to measure the evolution of the plant height (h) and to determine the location of the actual crop coefficients $K c$ by using the BREB method. In contrast to other methods, plant height is estimated first from PGC parameter, and then the term $P G C / h$ is correlated with $K c$. This allows two mathematical equations to be derived with which to model the relationships between these parameters, squared correlation coefficients of 0.993 and 0.979 were obtained when estimating h from $P G C$ and when calculating $K c$ from the term $P G C / h$, respectively, demonstrating the validity of the methodology. 
Later, the developed and validated methodology was also applied to another variety of lettuce (Lactuca sativa L. cv Little Gem) to obtain accurate crop coefficients $K c$ of the lettuce variety and use them in the estimation of water requirements to establish water balance and crop irrigation scheduling. The tested lettuce variety was justified by the considerable increase in cultivated area that this variety is experiencing due to an increasing commercial interest in this type of lettuce for national market and export. The Irrigation management carried out using the crop coefficients $K c$ obtained by this method for estimating water requirements was compared with an irrigation management based on objective criteria from the person responsible for irrigation, which permitted to detect deficiencies and excesses in irrigation management. The result was a potential reduction of $17.80 \%$ in water consumption for irrigation and an increase of $17.33 \mathrm{~kg} \cdot \mathrm{m}^{-3}$ in the potential productivity. Consequently, better economic crop yields associated with higher productivity and lower water irrigation consumption were obtained.

In other respects, irrigation scheduling and automation are usually conducted using models that are based on the measurement of the soil water content. In this sense, water balance has established itself as a good indicator of the growth and development of crops and is currently used in several automatic programming systems, primarily in intensive farming and microirrigation systems. Water balance analyses the gains and losses of water in a limited volume of soil to determine the water availability for crops and the soil water status. A parameter of great importance for the application of this method is the root depth $(z)$ which limits the soil volume to be considered in the water balance. In most cases the actual evolution of this parameter during crop development is not considered, using instead fixed tabulated values or values that have been proposed in the literature. However, during some periods of crop development, the soil profile that is considered for the water balance does not correspond to the profile that is actually explored by the root system, resulting in a mismatch in the water balance.

Considering this fact, a third action line have been established based on the development and validation of an operational and non-destructive methodology for obtaining predictive models of the root depth from the $P G C$ parameter obtained from digital images of the canopy, because a good relationship was observed between both parameters. According to this observation a methodology based on digital photography to determine the mathematical relationship between $P G C$ and $z$ was established and tested for two lettuce crop seasons (spring and autumn) at this area. Squared correlation coefficients of 0.997 
(spring season) and 0.998 (autumn season) were obtained, demonstrating the validity of this methodology. The implementation of these relationships in an automated irrigation management system allowed an optimization of the water resources due to the adjustment of soil water content to the actual profile explored by the crop root system.

Finally, in order to improve the methodologies developed and validated in the previous experiments, a complete and comprehensive study to select the optimal colour space and the most effective way to represent colour distributions in the process of automatic segmentation of digital images of the canopy for obtaining the $P G C$ parameter was carried out. A wide variety of colour models were considered for the study: RGB, rgb, XYZ, L*a*b*, L*u*v*, HSV, HLS, YCrCb, YUV, I1I2I3 and TSL. Furthermore, different possibilities to model the probability distribution of a given colour space for each colour were posed. The obtained results showed that the best colour spaces are those that separate luminance from chrominance. In particular, channel $\mathrm{a}^{*}$ in $\mathrm{L} * \mathrm{a} * \mathrm{~b} *$ model is found to be the optimal election, with an accuracy of $99.2 \%$ by itself. 


\section{Introducción}

En el actual contexto social y económico, el objetivo de una explotación agrícola es obtener los máximos beneficios. Esto significa, por un lado un uso más racional de los insumos ambientales (suelo-clima-agua) y por otro, el empleo de las técnicas de riego (Goncalves et al., 2011; Oron et al., 2002) y de cultivo apropiadas. En el sureste de España, debido al clima semiárido de la región, la escasez generalizada de agua para la agricultura ha generado una notable necesidad de desarrollar estrategias que mejoren la eficiencia del uso del agua (Molina-Martinez et al., 2011).

En este contexto, las técnicas de agricultura de precisión han contribuido a la mejora del uso del agua en los sistemas productivos, entre otras propuestas tecnológicas. Específicamente, en la actualidad, la implementación de las técnicas de visión artificial y en particular, de la fotografía digital en la agricultura, se ha intensificado considerablemente en los últimos años. Se incluyen algunos ejemplos como el monitoreo de cultivos, robótica, inspección no destructiva de las propiedades del producto, clasificación en líneas de procesamiento, control de calidad y en general en la automatización de procesos. El uso en estas aplicaciones tecnológicas se debe a que los sistemas de visión artificial proporcionan información variada acerca de la naturaleza y atributos de la escena capturada.

En lo referente a la gestión eficiente del agua, la aplicación de la fotografía digital en la agricultura de precisión permite el monitoreo del crecimiento de las plantas y la obtención de parámetros vegetativos de su desarrollo. Uno de los parámetros vegetativos relacionados es el índice de área foliar. Este parámetro determina la capacidad de la planta 
para captar la energía de la luz solar o la fracción de cobertura vegetal y está directamente relacionada con la evapotranspiración a través del coeficiente de cultivo.

La presente Tesis Doctoral desarrolla la aplicación y validación de técnicas no destructivas basadas en el procesamiento informático de imágenes digitales para la programación y gestión del riego de la lechuga (Lactuca sativa L.) en cultivares de creciente interés comercial ubicados en las provincias de Murcia y Albacete. Mediante estas técnicas se pretende optimizar el manejo productivo del agua de riego y el rendimiento económico del cultivo en zonas de limitada disponibilidad hídrica. La Tesis se presenta como un compendio de cinco publicaciones de acuerdo al Reglamento de Estudios Oficiales de Máster y Doctorado de la Universidad Politécnica de Cartagena, aprobado en Consejo de Gobierno de 14 de abril de 2011. Siguiendo las indicaciones de dicho Reglamento, la Memoria de Tesis se estructura como se expone a continuación.

Inicialmente, en el epígrafe 2 , se presentan los Objetivos generales y específicos de la Tesis, con el fin de describir las distintas líneas de actuación de la Tesis. Seguidamente, en el epígrafe 3, se detallan los Antecedentes y Estado del Arte. Esta sección pretende presentar al lector información actualizada sobre aquellos temas de interés esencial para el adecuado seguimiento de la Tesis, tales como la situación actual de la aplicación de la fotografía digital a la agricultura y su implicación en la determinación de parámetros biofísicos relacionados con las necesidades hídricas de los cultivos.

En el epígrafe 4 se presentan las diferentes Publicaciones que componen la Tesis, acompañada cada una de ellas, de un extenso resumen en el que se especifica la metodología empleada, los resultados alcanzados, las aportaciones más relevantes al campo de la investigación y las principales conclusiones obtenidas. En la primera de ellas, "Selection of device to determine temperature gradients for estimating evapotranspiration using energy balance method", publicada en la revista Agricultural Water Management, se lleva a cabo la calibración del método Bowen para la determinación de los coeficientes de cultivo, al mismo tiempo que se desarrolla un estudio comparativo de la sensibilidad de dicho método al empleo de diferentes sensores de medida de temperatura. La segunda publicación, "A digital image-processing-based method for determining the crop coefficient of lettuce crops in the southeast of Spain", publicada en la revista Biosystems Engineering, presenta un nuevo método basado en visión artificial para estimar el coeficiente de cultivo $K c$ de cultivos de lechuga a partir de la fracción de cobertura vegetal obtenida a partir de fotografías digitales del dosel vegetal. Esta metodología es posteriormente 
aplicada a la programación del riego de otra variedad de lechuga en la publicación " $D i$ gital photography applied to irrigation management of Little Gem lettuce", publicada en la revista Agricultural Water Management. La cuarta publicación, “Methodology for obtaining prediction models of the root depth of lettuce for its application in irrigation automation", también publicada en la misma revista, propone una nueva metodología para la obtención de modelos predictivos de la profundidad radicular de cultivos de lechuga a partir de la fracción de cobertura vegetal, obtenida mediante procesamiento de fotografías digitales de la cubierta vegetal. Finalmente, la quinta publicación "Study and comparison of color models for automatic image analysis in irrigation management applications", publicada de nuevo en Agricultural Water Management, presenta un estudio completo y exhaustivo para seleccionar el espacio de color óptimo y la forma más efectiva de representar las distribuciones de color en el proceso de segmentación automática de imágenes digitales de cubiertas vegetales para la obtención del parámetro fracción de cobertura vegetal.

El epígrafe 5 recoge las principales Conclusiones obtenidas en cada una de las líneas de actuación de la tesis y se proponen nuevas líneas de investigación que resultan de especial interés a la vista de los resultados y conclusiones obtenidos. Por último se presentan las Referencias bibliográficas y los Apéndices I y II, donde se adjuntan las Notificaciones de Aceptación de las Publicaciones que constituyen la Tesis, y los documentos acreditativos del Índice de Impacto de las revistas donde se publicaron. 



\section{Objetivos}

El objetivo general de esta Tesis Doctoral y sus líneas de investigación derivadas es la aplicación y validación de técnicas no destructivas basadas en el procesamiento informático de imágenes digitales para la programación y gestión del riego de la lechuga (Lactuca sativa L.) en cultivares de creciente interés comercial ubicados en las provincias de Murcia y Albacete, y lograr así una optimización del manejo productivo del agua de riego y del rendimiento económico del cultivo en zonas de limitada disponibilidad hídrica.

La consecución de este objetivo requiere la cuantificación exacta de las necesidades hídricas del cultivo y de los diferentes componentes del balance hídrico; así como identificar las variables de desarrollo vegetativo implicadas en el mismo, sus interrelaciones y grado de participación en el proceso transpirativo de la planta. El logro de este objetivo general aportará nuevos métodos y algoritmos basados en la fotografía digital y su procesamiento informático, susceptibles de ser implantados en nuevos sistemas automatizados de riego inteligente basados en visión computarizada.

Este objetivo general ha sido abordado estableciendo los ensayos desarrollados en la presente Tesis Doctoral, planteados considerando los siguientes objetivos específicos:

1. Calibrar una estación climática (sistema Bowen) para determinar los coeficientes de cultivo Kc reales de los cultivares de lechuga ensayados, adaptados a las condiciones climáticas del Sureste español y técnicas de cultivo propias de la zona, para emplearlos en la formulación de modelos estimativos; y contrastar el empleo de diversos sensores. 
2. Desarrollar y validar una nueva metodología operativa de procesamiento informático de imágenes digitales de la cubierta vegetal, para estimar el coeficiente de cultivo Kc de lechuga; caracterizado, mediante funciones matemáticas, por su relación con los parámetros fracción de cobertura vegetal y altura de la planta a lo largo del periodo vegetativo del cultivo.

3. Aplicar la metodología desarrollada en el objetivo anterior a la estimación de las necesidades hídricas y programación del riego de diferentes cultivares de lechuga en el Sureste español, y evaluar su implantación mediante indicadores de productividad de uso del agua.

4. Desarrollar y validar una metodología operativa para obtener modelos predictivos del espesor de la zona radicular de cultivares de lechuga, parámetro de gran importancia para la programación del riego mediante establecimiento del balance hídrico del cultivo, basada en su relación con la fracción de cobertura vegetal obtenida mediante procesamiento informático de imágenes digitales de la cubierta vegetal.

5. Analizar los espacios de color óptimos y forma más efectiva de representar las distribuciones de color en el proceso de segmentación automática de imágenes digitales de cubiertas vegetales para la obtención del parámetro fracción de cobertura vegetal. 


\section{Antecedentes y Estado del Arte}

En el actual contexto económico, el objetivo de una explotación agrícola es obtener los máximos beneficios en un entorno social y económico. Esto significa, por un lado un uso más racional de los recursos ambientales (suelo-clima-agua) y por otro, el empleo de las técnicas de riego (Goncalves et al., 2011; Oron et al., 2002) y las técnicas de cultivo apropiadas. La escasez generalizada de agua en muchas zonas áridas y semiáridas del mundo y en especial en el Sureste español, donde además el agua disponible suele tener una calidad agronómica media-baja, obliga a estudiar y desarrollar nuevos sistemas que optimicen el uso del agua en el regadío (Molina-Martinez et al., 2011).

La mejora en la eficiencia del uso del agua en la agricultura es, por tanto, un aspecto a mejorar a nivel mundial, y muy especialmente a escala europea, donde la Directiva Marco del Agua (DMA) se convierte en la base del resto de leyes que regulan el empleo del agua, apostando por una mejora en la eficiencia de su utilización, la conservación y protección medioambiental de las masas de agua de carácter ecológico, el aprovechamiento sostenible de los acuíferos y la eliminación del riesgo de contaminación de los cauces naturales por medio del empleo excesivo de fertilizantes y plaguicidas en la agricultura. En este contexto, la agricultura de precisión ha demostrado ser una solución para la mejora del uso del agua en los sistemas productivos, potenciando la aplicación de nuevos sistemas de riego, nuevas estrategias de programación, nuevos sensores que informen de las necesidades hídricas de los cultivos, y nuevos sistemas remotos que permitan la automatización y el desarrollo sostenible de los regadíos. 
La utilización de la fotografía digital y las técnicas de procesamiento de imágenes en estudios agronómicos constituye un recurso que ha tenido aplicación creciente, de manera particular, con el desarrollo de la tecnología digital, cuya utilización permite evaluaciones de muy diversa índole sobre una base cuantitativa (Ewing y Horton, 1999; Rodríguez et al., 2000). Estas técnicas se han convertido en una de las principales fuentes de información en tiempo real sobre diversos parámetros relacionados con el desarrollo y estado hídrico de los cultivos (Blasco et al., 2009; Lorente et al., 2012).

El empleo de métodos fotográficos ha dado buenos resultados, entre otros aspectos, para cuantificar la porosidad de barreras rompevientos, discriminando el área cubierta del espacio abierto (Kenney, 1987), establecer la condición de estrés de nitrógeno en maíz (Blackmer et al., 1996), cuantificar el número de flores de un árbol (Adamsen et al., 2000) o estimar el índice de área foliar en cebolla (Corcoles et al., 2013). Ovando et al. (1999) y Rodríguez et al. (2000) emplearon fotografías digitales y técnicas de interpretación de imágenes para determinar la fracción de cobertura en patata y Purcell (2000), de igual modo, desarrolló un método para determinar la proporción de suelo cubierto por hojas verdes en soja. Además, la aplicación de la fotografía digital y las técnicas de tratamiento e interpretación de imágenes se extiende a otras disciplinas como la silvicultura; por ejemplo, Meir et al. (2000) desarrollaron un método basado en la fotografía digital para medir la distribución vertical de la densidad de área foliar en bosques y Brown et al. (2000) estimaron las dimensiones de la copa en árboles llevando a cabo el análisis digital de fotografías verticales.

En lo referente a la gestión eficiente del agua, el empleo de la fotografía digital en agricultura de precisión permite el seguimiento del crecimiento y desarrollo de los cultivos, permitiendo así determinar sus necesidades hídricas mediante la obtención de parámetros biofísicos de la cubierta vegetal que están directamente relacionados con sus requerimientos hídricos, determinados mediante fotografía digital y técnicas de tratamiento de imágenes.

Uno de estos parámetros es el LAI (Leaf Area Index) (Watson, 1947) que hace referencia a la superficie foliar fotosintéticamente activa y está directamente relacionado con la capacidad del cultivo de captar la radiación solar incidente (Monsi y Saeki, 1953); además es utilizado como una herramienta de referencia en el desarrollo del cultivo (Fortin et al., 2008). Debido a que todos los métodos directos de medición del LAI son similares, en tanto que son extremadamente laboriosos, destructivos y costosos en términos 
de tiempo y dinero, se han desarrollado otros métodos indirectos de medición del LAI que implican menos procedimientos y en consecuencia menor tiempo de ejecución (Kirk et al., 2009). Por ejemplo, Lu et al. (2004) propusieron diversos modelos para estimar el área de una hoja de taro utilizando mediciones no destructivas de longitud y anchura, y Campillo et al. (2010) desarrollaron un sencillo y económico método para estimar el LAI en cultivos hortícolas utilizando el porcentaje de cobertura del suelo extraído de imágenes digitales. Esta relación entre el $L A I$ y la cobertura del suelo también ha sido demostrada en patata por Boyd et al. (2002), quienes obtuvieron una alta correlación incluso bajo extremos niveles de competencia y diferentes tipos de gestión.

Otro parámetro biofísico directamente relacionado con el estado de desarrollo del cultivo es el PGC (Percentage of Green Cover) o FVC (Fractional Vegetation Cover), que representa la fracción de suelo cubierto por vegetación. Se trata de un parámetro ampliamente utilizado para representar distintas funciones de crecimiento y desarrollo de los cultivos (Walthall et al., 2004; Laliberte et al., 2007; Richardson et al., 2001) y que normalmente se obtiene a partir de imágenes digitales utilizando técnicas de procesamiento e interpretación de imagen, que proporcionan resultados precisos (Congling et al., 2005).

Estudios recientes han puesto de manifiesto una fuerte relación entre el parámetro PGC y otros parámetros. Por ejemplo, Giacomelli et al. $(1996,1998)$ fueron capaces de determinar el estrés de nutrientes en plantas de lechuga empleando un sistema de visión artificial que obtiene el $P G C$ de plántulas de lechuga; Ling y Ruzhitsky (1992) encontraron una fuerte correlación entre peso fresco, peso seco y $P G C$, obtenido utilizando tecnología de procesamiento de imágenes en plántulas de tomate; Blasco et al. (2002) desarrollaron un sistema robótico basado en el análisis de imágenes para eliminar las malas hierbas en campos de lechuga basado en el tamaño del área proyectada; y Story et al. (2010) diseñaron un sistema de visión artificial para detectar la deficiencia de calcio en cultivos de lechuga bajo invernadero empleando cambios morfológicos, temporales y de color en la planta.

Las necesidades hídricas de un cultivo se corresponden con su evapotranspiración $(E T)$ en un determinado ambiente y bajo un manejo concreto del mismo; dicha ET es la suma de dos procesos que se producen de manera simultánea: la evaporación $(E)$ del agua almacenada en la capa superficial del suelo, y la transpiración $(T)$ de la cubierta vegetal (Jensen et al., 1990). En este último proceso, el agua absorbida por las raíces es posteriormente liberada a la atmósfera a través de los estomas (Sharma, 1985). Hay que indicar 
que la proporción de evaporación y transpiración en un cultivo varían en función de las diferentes fases de crecimiento y desarrollo. De este modo, cuando el cultivo se encuentra en las primeras fases de desarrollo predomina el suelo desnudo, y la evaporación es el proceso mayoritario. Sin embargo, conforme el cultivo se desarrolla va cubriendo progresivamente el suelo hasta llegar a la máxima cobertura. En este momento la pérdida de agua se deberá fundamentalmente a la transpiración (Calera, 2005).

El parámetro $P G C$ permite estimar las necesidades hídricas de los cultivos al estar directamente relacionado con la evapotranspiración $(E T c)$, la cual es calculada como el producto del coeficiente de cultivo $(K c)$ y la evapotranspiración de referencia (ETo) (Allen et al., 1998; Allen et al., 2011). Diversos autores han logrado obtener resultados satisfactorios al relacionar $P G C$ con el coeficiente de cultivo $K c$ en tomates (Hanson y May, 2005), judías (de Mederios et al., 2001) y cebollas (Lopez-Urrea et al., 2009) y se han desarrollado modelos matemáticos que, involucrando otras variables como la altura del cultivo, permiten estimar el coeficiente de cultivo $K c$ a partir del parámetro $P G C$ (Allen y Pereira, 2009); sin embargo, estudios llevados a cabo en cultivos de lechuga obtuvieron malas estimaciones (Grattan et al., 1998).

Las necesidades netas de agua para el riego se estiman mediante el balance hídrico en la zona radicular del cultivo (Eilers et al., 2007, Nishat et al., 2007, Panigrahi y Panda, 2003; Shang y Mao, 2006). Este método, como tal balance, recoge unas entradas y unas salidas de agua en la parcela cultivada, que inciden directamente en el proceso de la ET del cultivo. Entre las primeras, figuran la precipitación, las reservas de agua en el perfil del suelo y el agua aportada por ascensión capilar desde las capas más profundas a la zona del perfil donde el sistema radicular es efectivo en cuanto a la absorción de agua; entre las salidas del balance, se han de cuantificar la correspondiente $E T$, la percolación de agua más allá de la profundidad efectiva de desarrollo del sistema radicular y, eventualmente, la escorrentía superficial.

En el contexto de la presente Tesis Doctoral, la fotografía digital y las técnicas de tratamiento de imágenes constituyen también una excelente herramienta de ayuda a la programación del riego, dada la relación observada entre $P G C$ y la profundidad del sistema radicular, otro parámetro importante del desarrollo vegetativo del cultivo, cuya participación en el balance hídrico viene determinada por la necesidad de conocer el perfil de suelo explorado por el sistema radicular, en el cual es necesario mantener unas condiciones óptimas de humedad para el correcto desarrollo del cultivo (Rincón, 2005). La 
profundidad radicular está relacionada directamente con la tasa de profundización de las raíces, específica de cada cultivo, y con la textura del suelo, pues ésta determina la resistencia mecánica que ofrece el suelo al desarrollo radicular (Taylor y Brar, 1991). La profundidad radicular es una variable de entrada en los sistemas de programación del riego, que suele ser hallada mediante el empleo de valores fijos tabulados o propuestos por la literatura.

El conocimiento del valor de profundidad radicular en cada momento del desarrollo del cultivo permite optimizar las metodologías existentes de programación del riego basadas en el conocimiento del estado hídrico del suelo, ya que consiguen establecer un balance hídrico ajustado únicamente a la zona de absorción radicular. Este hecho demuestra la necesidad de estudiar nuevas metodologías que permitan obtener modelos de evolución de la profundidad radicular en cada momento del desarrollo del cultivo (Sammis et al., 2012; Ma et al., 2013).

Así pues, la fotografía digital y las técnicas de tratamiento de imágenes constituyen una herramienta relevante en la obtención del parámetro $P G C$, que permite determinar las necesidades hídricas de los cultivos al estar directamente relacionado con la ET a través del coeficiente de cultivo $K c$; y establecer la programación y gestión del riego, al estar relacionado también con la profundidad radicular del cultivo. En este contexto, el análisis automático de imágenes digitales de cultivos es un campo de investigación interesante y activo, donde convergen la visión por computador y la agromótica. 



\section{Publicaciones que constituyen la Tesis}

A continuación se presentan las diferentes Publicaciones que componen la Tesis, acompañada cada una de ellas, de un extenso resumen en el que se especifica la metodología empleada, los resultados alcanzados, las aportaciones más relevantes al campo de la investigación y las principales conclusiones obtenidas. En la primera de ellas, "Selection of device to determine temperature gradients for estimating evapotranspiration using energy balance method", publicada en la revista Agricultural Water Management, se lleva a cabo la calibración del método Bowen para la determinación de los coeficientes de cultivo, al mismo tiempo que se desarrolla un estudio comparativo de la sensibilidad de dicho método al empleo de diferentes sensores de medida de temperatura. La segunda publicación, "A digital image-processing-based method for determining the crop coefficient of lettuce crops in the southeast of Spain", publicada en la revista Biosystems Engineering, presenta un nuevo método basado en visión artificial para estimar el coeficiente de cultivo $K c$ de cultivos de lechuga a partir de la fracción de cobertura vegetal obtenida a partir de fotografías digitales del dosel vegetal. Esta metodología es posteriormente aplicada a la programación del riego de otra variedad de lechuga en la publicación " $D i$ gital photography applied to irrigation management of Little Gem lettuce", publicada en la revista Agricultural Water Management. La cuarta publicación, “Methodology for obtaining prediction models of the root depth of lettuce for its application in irrigation automation", también publicada en la misma revista, propone una nueva metodología para la obtención de modelos predictivos de la profundidad radicular de cultivos de lechuga a partir de la fracción de cobertura vegetal, obtenida mediante procesamiento de fotografías 
digitales de la cubierta vegetal. Finalmente, la quinta publicación "Study and comparison of color models for automatic image analysis in irrigation management applications", publicada de nuevo en Agricultural Water Management, presenta un estudio completo y exhaustivo para seleccionar el espacio de color óptimo y la forma más efectiva de representar las distribuciones de color en el proceso de segmentación automática de imágenes digitales de cubiertas vegetales para la obtención del parámetro fracción de cobertura vegetal. 


\subsection{Publicación 1}

\section{Selection of device to determine temperature gradients for estimating evapotranspiration using energy balance method}

D. Escarabajal-Henarejos ${ }^{1}$, D.G. Fernández-Pacheco², J.M. Molina-Martínez ${ }^{1}$, L. Martínez-Molina ${ }^{3}$, A. Ruiz-Canales ${ }^{4}$

${ }^{1}$ Grupo de Investigación en Ingeniería Agromótica y del Mar. Universidad Politécnica de Cartagena, $\mathrm{P}^{\mathrm{o}}$ Alfonso XIII 52, 30203 Cartagena, Murcia.

${ }^{2}$ Departamento de Expresión Gráfica. Universidad Politécnica de Cartagena, Campus de la Muralla del Mar, C/ Doctor Fleming s/n, 30202 Cartagena, Murcia.

${ }^{3}$ Instituto Técnico Agronómico Provincial. Avda. Gregorio Arcos s/n, 02080 Albacete.

${ }^{4}$ Departamento de Ingeniería. Universidad Miguel Hernández de Elche, Ctra. de Beniel km 3.2, 03312 Orihuela, Alicante.

\section{RESUMEN}

Entre las metodologías que estudian el intercambio de energía y masa durante el proceso de evapotranspiración, los métodos micrometeorológicos proporcionan una de las mejores herramientas para elaborar modelos y comprender el proceso de interacción entre el cultivo y el ambiente. Concretamente, el método de la Razón de Bowen-Balance de Energía (RBBE) ha sido empleado por varios autores de la literatura para estimar la evapotranspiración de los cultivos en tiempo real, obteniendo resultados precisos. Para el 
cálculo de la evapotranspiración, este método requiere obtener los gradientes de temperatura media sobre la cubierta vegetal, los cuales son medidos en los equipos comerciales empleados con la ayuda de termopares (TMPs). Sin embargo, una alternativa al empleo de este tipo de sondas termométricas son los detectores de resistencias metálicas (RTDs). Estos sensores presentan ventajas de exactitud, tolerancia y estabilidad, entre otras, frente a los TMPs. El presente artículo evalúa el empleo de ambas sondas termométricas (TMPs y RTDs) en la estimación de la evapotranspiración a partir del método RBBE. Para este propósito, se determinó la evapotranspiración de un cultivo de referencia (Festuca arundinacea L. cv. Schereb.) mediante un lisímetro de pesada y fue estimada empleando la ecuación de Penman-Monteith FAO-56 y el método RBBE, utilizando en éste último tanto TMP como RTD para obtener los gradientes medios de temperatura. Los resultados del análisis comparativo entre los valores de ET medidos por el lisímetro y los valores obtenidos usando el método RBBE denotan una mayor similitud, obteniendo un coeficiente de correlación de 0,958 cuando se emplean RTDs y de 0,923 con TMPs. Los valores de ET calculados empleando TMPs y RTDs también fueron comparados entre sí para estimar el grado de similitud entre ambos. Los resultados no mostraron diferencias significativas, obteniéndose para todos los días analizados un coeficiente de correlación superior a 0,985 .

\section{INTRODUCCIÓN}

La evapotranspiración (ET) puede definirse como el proceso por el cual el agua se transfiere desde la superficie terrestre hacia la atmósfera (Doorenbos y Pruitt, 1977). Esta evapotranspiración comprende tanto la evaporación de agua líquida o sólida directamente desde el suelo, láminas de agua o superficies vegetales, como la pérdida de agua debida a la transpiración, que es el proceso físico y biológico llevado a cabo por los estomas de las hojas de las plantas (Jensen et al., 1990). Ambos procesos suponen el cambio de estado del agua de líquido a vapor. En lo que concierne a la evaporación, ésta depende esencialmente de las características climáticas. Sin embargo, la transpiración es un proceso más complejo, pudiendo estar influenciada por factores de índole fisiológico y aerodinámico, asociados a las diferentes especies vegetales, y puede estar limitada por las disponibilidades hídricas (Fernández García, 1995).

En la naturaleza, ambos procesos tienen lugar simultáneamente, y no es fácil estimar qué cantidad de vapor de agua se pierde a través de cada uno de ellos. Por este motivo se introduce el concepto de evapotranspiración, considerada como una pérdida 
conjunta de un sistema particular (Allen et al., 1998, 2007). La ET es un fenómeno de gran interés en diversas disciplinas y uno de los más difíciles de cuantificar y medir experimentalmente (Cui y Zornberg, 2008), lo que ha llevado al desarrollo de multitud de métodos, técnicas y ecuaciones empíricas, capaces de obtener estimaciones exactas y precisas (Cancela et al., 2006; Gocic y Trajkovic, 2010, 2011; Fernández-Pacheco et al., 2014). Esta cuantificación de la evapotranspiración es importante para la programación y gestión del riego (Aydin, 2008; Fandiño et al., 2012).

Los avances en la estimación de la evapotranspiración, derivaron de la introducción, por parte de Penman (1948) y Thornthwaite (1948), del concepto de evapotranspiración potencial $(E T P)$. Este concepto expresa de forma más exacta la tasa máxima de transferencia hídrica entre la superficie terrestre y la atmósfera. El método de cálculo de Thornthwaite, ha sido ampliamente utilizado por su sencillez, así como por requerir datos disponibles de manera rutinaria en las estaciones meteorológicas convencionales. Sin embargo, se ha comprobado que subestima la ET en zonas áridas y la sobreestima en climas húmedos (Ahmadi y Foodladmand, 2008). Además, el método requiere ser calibrado al cambiar de clima (Al-Ghobari, 2000). Varias décadas después, Doorenbos y Pruitt (1977) definen un nuevo concepto de evapotranspiración, de referencia, exponiendo los nuevos objetivos a cubrir en las líneas de investigación.

Existe una amplia variedad de métodos para estimar la ET (Itier, 1996; Rana y Katerji, 2000; Allen et al., 2011a,b), y el empleo de un método u otro depende de la precisión requerida y los costes de las medidas. Con el fin de resumir los diferentes métodos para la estimación de $E T$, varios autores distinguen entre métodos directos y de estimación (Maidment, 1992). Otras clasificaciones propuestas por Jensen et al. (1990), Martín de Santa Olalla y de Juan (1993) y Rosenberg et al. (1983), los clasifican en métodos basados en el balance hídrico del suelo, en parámetros climátológicos, o parámetros micrometeorológicos, respectivamente.

Los métodos directos están basados en el control de las entradas y salidas de agua en el suelo, calculando la ET para un intervalo temporal determinado, como la diferencia entre las aportaciones de agua por precipitación o riego y el drenaje, usando para ello lisímetros (Kirkham et al., 1991). Un resumen detallado del empleo de lisímetros para el cálculo de ET puede encontrarse en las publicaciones de Harrold et al. (1966), Aboukhaled et al. (1982), Howell et al. (1985), Marek et al. (1988), y Pruitt y Lourence (1985). Los lisímetros han sido ampliamente utilizados como referencia para el 
desarrollo, calibración y validación de otros métodos de estimación de ET (Makkink, 1957; Jensen, 1974; Doorenbos y Pruitt, 1977; Wright, 1981, 1982; Allen et al., 1989; Jensen et al., 1990; Unlu et al., 2010).

Aunque varios autores han propuesto diferentes métodos para estimar la ET, aún no existe un consenso universal acerca de cuál es el más adecuado para cada clima, requiriendo además de rigurosas calibraciones locales (DehghaniSanij et al., 2004; Ahmadi y Foodlandmand, 2008). La clasificación propuesta por Rosenberg et al. (1983) incluye un grupo llamado "micrometeorológicos" en el que se estima la ET en cortos intervalos de tiempo (menores de 30 minutos), por lo que permite estimar este parámetro en tiempo real. Entre estos métodos micrometeorológicos están los siguientes: Eddy covarianza (EC) (Shaw et al., 2003; Meyers y Baldocchi, 2005), método aerodinámico (Rana et al., 1990), escintilometría (Hartogensis et al., 2003; De Bruin, 2008), y el método del Ratio de Bowen-Balance de Energía (RBBE) (Bowen, 1926). Concretamente, el método RBBE permite obtener buenas estimaciones de evapotranspiración de los cultivos en tiempo real y requiere de un equipamiento que puede ser fácilmente obtenido en comparación con otros métodos existentes como la Eddy covarianza (Uddin et al., 2013) o la lisimetría (Dicken et al., 2013). El método permite estimar la evapotranspiración como una componente del balance de energía, forzando su cierre mediante la utilización del ratio de Bowen (Bowen, 1926), basada en gradientes de temperatura del aire y presión de vapor de agua. Es un método no destructivo, que no requiere datos aerodinámicos y que puede ser automatizado utilizando un sistema Bowen-Campbell (Campbell Scientific, 1998).

El método RBBE ha sido ampliamente utilizado para estimar el flujo de vapor de agua sobre superficies evaporantes (Savage et al., 2009; Elsawwaf et al., 2010; Potter et al., 2011; Andreas et al., 2013; Peake et al., 2013) y ha sido aplicado para calibrar y validar los modelos de evapotranspiración de referencia, también a escala regional (Xing et al., 2008; Zeggaf et al., 2008; Unlu et al., 2010; Bezerra et al., 2012; Uddin et al., 2013), incluso bajo condiciones advectivas (Gavilán y Berengena, 2007). BalbontinNesvara et al. (2011) evaluaron y compararon el método EC y RBBE para la estimación de la ET diaria en un viñedo regado situado en la localidad semiárida de Tarazona de la Mancha (España), obteniendo valores muy similares, con subestimaciones prácticamente despreciables de ET por parte del RBBE en relación al método EC, justificando así la validez y precisión del método RBBE. 
Los equipos comerciales empleados actualmente en investigación y basados en el método RBBE determinan los gradientes de temperatura mediante el uso de termopares (p.e. Cromo-Constantan). Estos termopares (TMPs) están protegidos de la radiación directa y de agentes externos por tubos aspirados que hacen circular un flujo constante de aire a través de ellos. Los gradientes de presión de vapor son determinados por un higrómetro de alta precisión (p.e. un higrómetro de espejo de punto de rocío), alimentado mediante una bomba aspirante. Estos componentes tienen un elevado coste de adquisición y requieren un mantenimiento y conservación constantes para garantizar la fiabilidad de las medidas obtenidas. Sin embargo, la existencia en el mercado de sondas combinadas de temperatura y humedad, consistentes en un sensor termométrico con resistencia metálica (RTD) y una sonda capacitiva de humedad, permiten obtener los gradientes requeridos por la razón de Bowen mediante un dispositivo más simplificado, robusto y que requiere un menor mantenimiento (Fritschen y Simpson, 1982). Además, este tipo de sondas presentan ciertas ventajas frente a los convencionales TMPs, tales como su alta precisión y mejor estabilidad y linealidad, así como su bajo coste (Savage, 2010).

En este artículo, se determinó la evapotranspiración de un cultivo de referencia (Festuca arundinacea L. cv. Schreb.) utilizando un lisímetro de pesada, la ecuación de Penman-Monteith FAO-56 y el método RBBE, comparando posteriormente los valores obtenidos por cada método. Además, se desarrolló una evaluación y análisis comparativo del comportamiento de ambos sistemas (TMPs y RTDs) para la determinación de los gradientes de temperatura requeridos por el método de la razón de Bowen. Los resultados obtenidos fueron comparados con los valores proporcionados por el lisímetro de pesada, demostrando la idoneidad de los RTDs para ser empleados en sistemas basados en el ratio de Bowen para medir los gradientes de temperatura en sustitución de los tradicionales TMPs.

\section{MATERIALES Y MÉTODOS}

Se han aplicado de forma paralela tres métodos diferentes para determinar la evapotranspiración de un cultivo de referencia (Festuca arundinacea L. cv. Schreb.): lisimetría, ecuación de Penman-Monteith FAO-56 y método RBBE. En particular para el método RBBE, se han empleado dos instrumentos diferentes (TMPs y RTDs) para medir los gradientes de temperatura. En los siguientes párrafos se realiza una descripción más detallada del estudio. 


\subsection{Zona experimental}

El trabajo experimental fue realizado durante un periodo de 40 días desde septiembre a octubre de 2011 en la finca experimental 'Las Tiesas' (latitud 39³ '37' ' $\mathrm{N}$, longitud 2 ${ }^{\circ} 6^{\prime} \mathrm{O}$ y altitud $695 \mathrm{~m}$ ) ubicada en Albacete (España), y gestionada por el Instituto Técnico Agronómico Provincial de Albacete (ITAP).

El clima de la zona es semiárido, caracterizado por una pronunciada variación estacional que se corresponde a su naturaleza continental, con una temperatura media de $4,5^{\circ} \mathrm{C}$ en el mes más frío (enero) y de $24-26^{\circ} \mathrm{C}$ en el mes más caluroso (julio). La temperatura media anual es aproximadamente de $13,7^{\circ} \mathrm{C}$ y la precipitación media anual es $320 \mathrm{~mm}$, principalmente concentrada en primavera y otoño. Una descripción más detallada del clima de la zona la proporciona López-Urrea et al. (2006a). La clasificación agroclimática de Thornthwaite (Thornthwaite, 1948) caracteriza el clima local como semiárido (D), mesotérmico (B'2), con una total falta de condiciones de humedad (d), y con una concentración moderada de la demanda de agua en verano (b'3).

El suelo se clasifica como "Petrocalcic Calcixerepts" (Baillie, 2001) y tiene una profundidad media de $50 \mathrm{~cm}$, limitada por la existencia de un horizonte petrocálcico más o menos fragmentado. La textura es franco-arcillo-arenosa (Arena: 13,4\%, Limo: 48,9\% y Arcilla: 37,7\%). El suelo tiene $\mathrm{pH}$ básico y es pobre en materia orgánica y en nitrógeno total y con un alto contenido en caliza activa y potasio.

El estudio se realizó sobre en parcela de 1,1 ha $(99,0 \mathrm{~m}$ x 112,5 m) nivelada de césped (Festuca arundinacea L. cv. Schreb.), la cual es usada como superficie de referencia para la medida de ET. La parcela estaba periódicamente segada y regada con un sistema automatizado de riego por aspersión mediante cobertura total enterrada, evitando con ello cualquier tipo de restricción hídrica. Durante el estudio, la altura del césped estuvo siempre entre 10 y $15 \mathrm{~cm}$, no existiendo agua extra en el dosel.

La parcela estaba también provista de un lisímetro de pesada continua con registro electrónico de datos, que permitió llevar a cabo medidas de evapotranspiración de referencia, y una estación agroclimática situada a $10 \mathrm{~m}$ del lisímetro, la cual permitió determinar la ET empleando la metodología FAO-56. Además, una estación Bowen ubicada dentro de la parcela permitió registrar las variables climáticas requeridas por el método RBBE. La Fig. 5.1 muestra la localización de los equipos en la parcela experimental. 


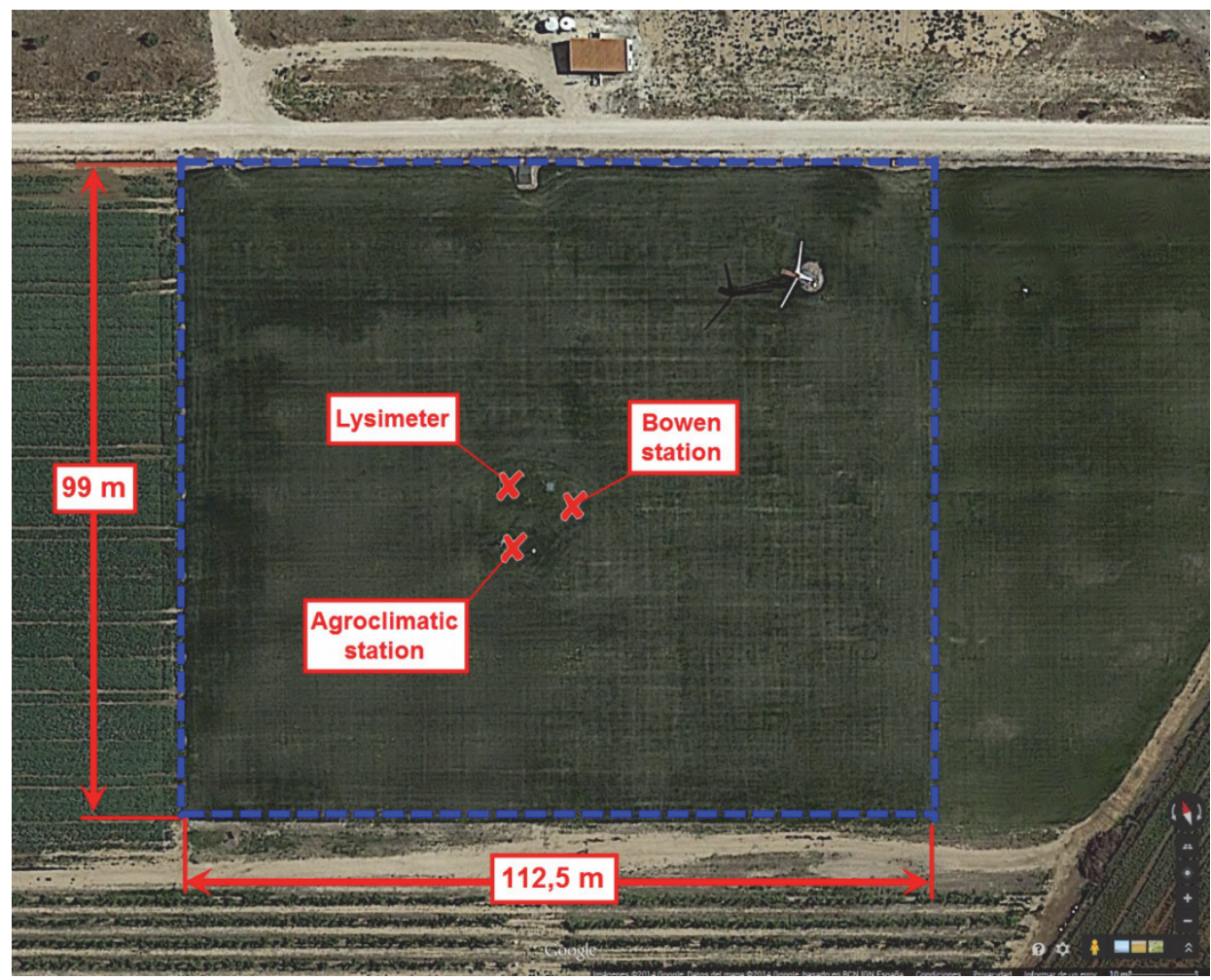

Fig. 5.1. Localización del lisímetro, estación agroclimática y estación Bowen en la parcela experimental.

Las condiciones climáticas fueron muy regulares durante el periodo de estudio, con valores de diarios de radiación neta en torno a $25 \mathrm{MJ} \cdot \mathrm{m}^{-2} \cdot \mathrm{d}^{-1}$ al inicio del estudio y 20 $\mathrm{MJ} \cdot \mathrm{m}^{-2} \cdot \mathrm{d}^{-1}$ en los últimos días. Únicamente se presentaron episodios de nubosidad los días 261, 266, 267, 268, 272, 273274 y 280. Durante el periodo se registró una temperatura máxima media de $23,4^{\circ} \mathrm{C}$ y una temperatura mínima media de $12,3^{\circ} \mathrm{C}$. La velocidad media diaria del viento, medida a $2 \mathrm{~m}$ sobre el nivel del suelo, varió entre 1,04 y $3,98 \mathrm{~m} \cdot \mathrm{s}^{-1}$. Durante el estudio, la lluvia estuvo prácticamente ausente. Sólo se presentó un episodio de precipitación, el cual aportó 8,85 mm. La ET acumulada fue de 163,27 $\mathrm{mm}$, obteniéndose un valor medio de $4,71 \mathrm{~mm} \cdot \mathrm{d}^{-1}$ durante la primera mitad del periodo $\mathrm{y}$ de $3,45 \mathrm{~mm} \cdot \mathrm{d}^{-1}$ durante el segundo periodo (Fig. 5.2). Esta ET fue principalmente compensada por el riego, que supuso un aporte total de agua de $164,87 \mathrm{~mm}$ durante el estudio.

\subsection{Lisímetro de pesada}

Para obtener medidas reales de evapotranspiración, se empleó un lisímetro de pesada continua con registro electrónico de datos. Este sistema también fue empleado con éxito por López-Urrea et al. (2006a, 2009a,b). El lisímetro está ubicado en el centro de la 
parcela (Fig. 5.1). Las dimensiones del recipiente eran $2,7 \mathrm{~m} \mathrm{x} 2,3 \mathrm{~m}$, con una profundidad de 1,7 m y una masa total aproximada de 14,5 t, y estaba cultivado con la misma especie (F. arundinacea L. cv. Schreb.) de modo que las plantas situadas dentro del recipiente descrito están en las condiciones lo más parecidas posibles a un cultivo normal que realice cualquier agricultor.
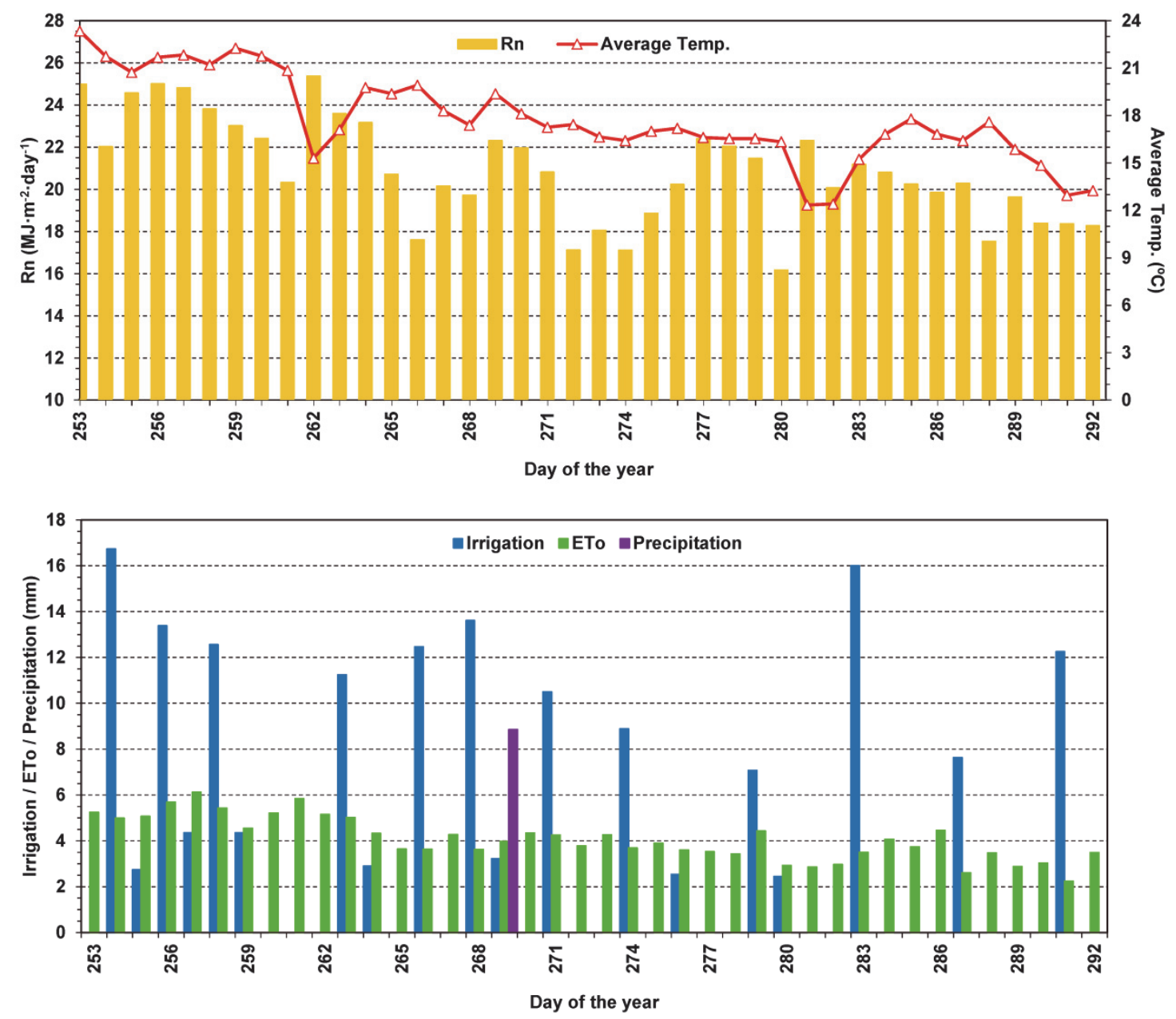

Fig. 5.2. Datos diarios registrados de radiación neta $\left(R_{n}\right)$, temperatura media, riego, evapotranspiración de referencia $(E T o)$ y precipitación durante el ensayo.

El recipiente del lisímetro estaba situado sobre un sistema de balanzas y un contrapeso, que contrarresta la carga muerta del suelo y el recipiente. El factor de desmultiplicación del sistema es de 1000:1. El sistema de balanzas incluía una célula de carga (modelo SB2, Epelsa Ind., S.L., Madrid, España), con una capacidad nominal de $50 \mathrm{~kg}$ y un rango de salida de $2 \mathrm{mV} \cdot \mathrm{V}^{-1}$ de excitación, y una alimentación de $5 \mathrm{~V}$ a plena carga. La célula de carga está conectada a un visor electrónico (modelo SMART, UTILCELL, Barcelona, España), con una resolución de 250 g, lo que equivale a 0,040 $\mathrm{mm}$ de ET. Por tanto, el lisímetro dispone del equipamiento necesario para realizar un 
balance hídrico completo y evaluar con precisión tanto los aportes (lluvia y riego) como las pérdidas (evapotranspiración y drenaje profundo).

Los datos de peso generados por el lisímetro y registrados en el visor, fueron almacenados en un datalogger CR10X (Campbell Scientific Spain Inc., CSI. Logan, UT, EE.UU.), que estaba programado para efectuar lecturas de peso cada segundo y generar registros cada 15 min durante todo el periodo de estudio. Por ejemplo, se produjeron algunas pérdidas de datos ocurridas durante el riego y precipitación, calibración, y cuando se llevó a cabo la siembra en el interior del tanque del lisímetro. Los datos resultantes se recopilaron para obtener una medición directa y precisa de ETo en las condiciones climáticas de la zona.

\subsection{Ecuación de Penman-Monteith FAO-56}

Además de los datos proporcionados por el lisímetro, la evapotranspiracón también fue calculada empleando la ecuación de Penman-Monteith FAO-56 (Allen et al., 1998):

$$
\text { ETo }=\frac{0,408 \Delta\left(R_{n}-G\right)+\gamma \frac{37}{T_{a}+273} u_{2}\left(e_{s}-e_{a}\right)}{\Delta+\gamma\left(1+0,34 u_{2}\right)}
$$

donde ETo representa la evapotranspiración de referencia horaria $\left(\mathrm{mm}^{\mathrm{h}} \mathrm{h}^{-1}\right) ; \Delta$ representa la pendiente de la curva de presión de vapor en saturación frente a la temperatura $\left(\mathrm{kPa}^{\circ}{ }^{\circ} \mathrm{C}^{-}\right.$ $\left.{ }^{1}\right) ; R_{n}$ es la radiación neta en la superficie del cultivo $\left(\mathrm{MJ} \cdot \mathrm{m}^{-2} \cdot \mathrm{h}^{-1}\right) ; G$ indica la densidad del flujo de calor hacia el suelo $\left(\mathrm{MJ} \cdot \mathrm{m}^{-2} \cdot \mathrm{h}^{-1}\right) ; \gamma$ es la constante psicrométrica $\left(\mathrm{kPa}^{\circ} \mathrm{C}^{-1}\right)$; $T_{a}$ es la temperatura media del aire medida a $2 \mathrm{~m}$ de altura $\left({ }^{\circ} \mathrm{C}\right) ; u_{2}$ es la velocidad media horaria del viento medida a $2 \mathrm{~m}$ de altura $\left(\mathrm{m} \cdot \mathrm{s}^{-1}\right) ; e_{s}$ define la presión de saturación de vapor a temperatura del aire $T_{a}(\mathrm{kPa})$ y $e_{a}$ indica la presión real de vapor $(\mathrm{kPa})$.

Todos los datos meteorológicos fueron recogidos por una estación meteorológica situada sobre el cultivo de referencia a unos $10 \mathrm{~m}$ del lisímetro (Fig. 5.1). La estación estaba equipada con un datalogger CR10X (Campbell Scientific Spain Inc., CSI. Logan, UT, EE.UU.) y sensores para medida de temperatura y humedad relativa del aire (sonda MP100, Campbell Scientific, Logan, UT, EE.UU.), radiación solar (piranómetro CM14, KIPP\&ZONEN Delft, Holanda), velocidad y dirección del viento (anemómetro A100R y veleta W200P, Vector Instruments Ltd., R.U.) y precipitación (pluviómetro ARG100, Campbell Scientific, Logan, UT, EE.UU.). En cuanto a la sonda de humedad y 
temperatura, ésta se situó a 1,5 m de altura sobre la superficie, mientras que los sensores de viento se colocaron a $2 \mathrm{~m}$ de altura.

\subsection{Método de la Razón de Bowen-Balance de Energía}

El método RBBE fue el tercer método elegido para estimar la $E T$ en el estudio. En este método, basado en los gradientes de temperatura y presión de vapor de agua sobre la superficie del cultivo, se emplearon dos dispositivos para las medidas de temperatura: TMPs y RTDs. Se llevó a cabo un análisis comparativo de los resultados proporcionados por ambos procedimientos. Se determinó cada uno de los componentes del balance de energía sobre la superficie de referencia empleando la ecuación:

$$
R_{n}-G=\lambda E+H
$$

donde $R_{n}$ es la irradiancia neta $\left(\mathrm{W} \cdot \mathrm{m}^{-2}\right), G$ define el flujo de calor en el suelo $\left(\mathrm{W} \cdot \mathrm{m}^{-2}\right), \lambda E$ representa el flujo de calor latente $\left(\mathrm{W} \cdot \mathrm{m}^{-2}\right)$, es decir, la evapotranspiración, y $H$ indica el flujo de calor sensible $\left(\mathrm{W} \cdot \mathrm{m}^{-2}\right)$. Todas las variables climáticas y meteorológicas implicadas en el método RBBE fueron registradas y procesadas por un equipo alimentado por panel solar y batería, y situado en la parcela experimental a unos $15 \mathrm{~m}$ del lisímetro (Fig. 5.1).

La ubicación tanto del lisímetro como de la estación Bowen debe cumplir con los requerimientos de 'fetch' para permitir la formación del perfil logarítmico de velocidad del viento. Esos requerimientos son: i) que la superficie sembrada por el cultivo sea lo suficientemente extensa, sobre todo en la dirección del viento dominante; ii) que durante el periodo de estudio se presenten condiciones de estabilidad neutral, que permitan que los coeficientes de transporte turbulento en dirección vertical sean iguales para el caso del transporte del vapor de agua y calor sensible; y iii) que los instrumentos utilizados sean lo suficientemente sensibles como para detectar diferencias en temperatura, humedad y velocidad del viento a dos alturas. La localización empleada tanto para el lisímetro como para la estación Bowen en la parcela experimental (Fig. 5.1) permitió mantener un 'fetch' superior a 49,5 m independientemente de la dirección de los vientos dominantes. Este 'fetch' se estimó suficiente para la realización de las medidas, pues cualquiera que fuera la dirección del viento éste fue mayor que 20 veces la altura a la que se situaron los brazos del equipo (Heilman et al., 1989).

La radiación neta $\left(R_{n}\right)$ fue medida por medio de un radiómetro neto (NR-LITE, Campbell Scientific Spain Inc., CSI. Logan, UT, EE.UU.), ubicado a 2 m sobre el suelo. 
Los valores de flujo de calor en el suelo $(G)$ se midieron en un lugar representativo del suelo, y los valores se calcularon con el método combinado (Payero et al., 2003), el cual corrige los flujos térmicos medidos por platos de flujo de calor enterrados, evaluando la capacidad térmica del suelo superficial midiendo el cambio en su temperatura en el tiempo y el efecto del contenido de humedad en el suelo. Para ello se ubicaron dos platos HFP01 (Hukseflux, Holanda) enterrados a $8 \mathrm{~cm}$ y separados $1 \mathrm{~m}$, y cuatro termopares $(2+2)$ de cromo-constantan (TCAV, Tipo E) instalados sobre la vertical de los platos térmicos, a 2 y $6 \mathrm{~cm}$ de profundidad, junto a un reflectómetro de humedad volumétrica CS616 (Campbell Scientific Spain Inc., CSI. Logan, UT, EE.UU.).

Además de calcular la energía disponible $\left(R_{n}-G\right)$, el método RBBE también requiere determinar los gradientes de temperatura y humedad sobre el cultivo de referencia. Ambos gradientes fueron medidos con sensores instalados en dos brazos metálicos a diferentes alturas: 0,55 m y 1,19 m. El gradiente de temperatura se evaluó con dos termopares de hilo fino tipo E (cromo-constantan) de $76 \mu \mathrm{m}$ de diámetro, aspirados y protegidos de la radiación directa. A su vez, el gradiente de humedad se comprobó mediante un higrómetro de espejo de punto de rocío (ALMEMO, Ahlborn Mess. Und R., Alemania), compartido por ambos brazos y alimentado alternativamente desde cada altura mediante dos bombas independientes. Paralelamente, y con el objetivo de obtener medidas comparativas, también se evaluaron ambos gradientes por medio de dos sensores CS215 (Campbell Scientific Spain Inc., CSI. Logan, UT, EE.UU.), instalados en cada uno de los brazos del equipo RBBE. Estos sensores están equipados cada uno de ellos con una sonda termométrica para la medida de la temperatura del aire, constituida por una resistencia metálica de platino de $1000 \Omega$, y un sensor capacitivo de humedad relativa, basado en cambios de la capacitancia eléctrica del aire.

La estación (Fig. 5.3) además está equipado con un pluviómetro RAIN-O-MATIC (Campbell Scientific Spain Inc., CSI. Logan, UT, EE.UU.) y un anemómetro de cazoletas A100 (Campbell Scientific, Logan, UT) que permite corregir los valores de $R_{n}$ en función de la velocidad del viento siguiendo las recomendaciones del fabricante del radiómetro.

El equipo RBBE se programó para leer cada una de las variables climáticas con una frecuencia de $1 \mathrm{~Hz}$. Cada dos minutos se alternaba la toma de aire para el higrómetro, dando un margen de $40 \mathrm{~s}$ para la estabilización de las medidas. Los datos de todas las variables se registraron cada segundo, almacenándose los valores medios cada 5, 20 y 60 
minutos en un datalogger CR1000 (Campbell Scientific Spain Inc., CSI. Logan, UT, EE.UU.).

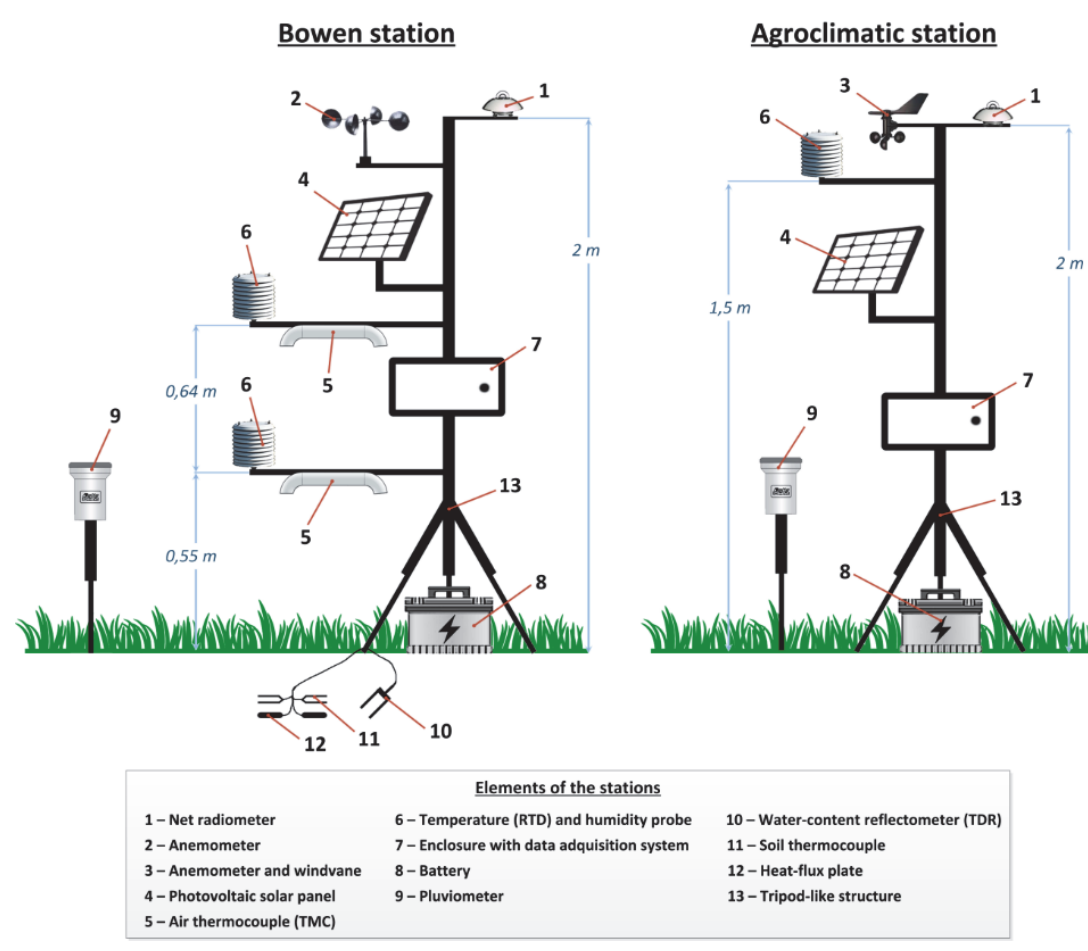

Fig. 5.3. Diseño y componentes de la estación Bowen y estación agroclimática empleadas en el ensayo.

Las medidas de las diferencias de temperatura $\left(\Delta T=T_{1}-T_{2}\right)$ y presión de vapor $\left(\Delta e=e_{1}-e_{2}\right)$ entre las $\operatorname{cotas} z_{1}=0,55$ y $z_{2}=1,19$ fueron utilizadas para calcular el ratio de Bowen $(\beta)$ de acuerdo a la siguiente ecuación:

$$
\beta=\frac{H}{\lambda E}=\gamma \frac{\Delta T}{\Delta e}
$$

donde $\beta$ es el ratio de Bowen, $H$ es el flujo de calor sensible $\left(\mathrm{W} \cdot \mathrm{m}^{-2}\right), \lambda E$ es el flujo de calor latente $\left(\mathrm{W} \cdot \mathrm{m}^{-2}\right), \gamma$ es la constante psicrométrica $\left(\mathrm{kPa} \cdot{ }^{\circ} \mathrm{C}-1\right), \Delta T$ es el gradiente de temperatura del aire $\left({ }^{\circ} \mathrm{C}\right)$ entre dos alturas sobre la superficie, y $\Delta e$ es el gradiente de presión de vapor $(\mathrm{kPa})$ entre las mismas alturas que $\Delta T$. Posteriormente, el ratio de Bowen $(\beta)$ fue utilizado en la Ec. 4 para obtener los valores medios de flujo de calor latente $(\lambda E)$, es decir, la evapotranspiración, para cada periodo horario:

$$
\lambda E=\frac{\left(R_{n}-G\right)}{1+\beta}
$$

En la Ec. 4, $\lambda E$ representa la $E T$ expresada en términos de energía $\left(\mathrm{W} \cdot \mathrm{m}^{-2}\right), R_{n}$ es la irradiancia neta $\left(\mathrm{W} \cdot \mathrm{m}^{-2}\right), G$ indica el flujo de calor en el suelo $\left(\mathrm{W} \cdot \mathrm{m}^{-2}\right)$ y $\beta$ representa el ratio de Bowen. 
Una limitación del método RBBE que cabe mencionar es su inestabilidad y pérdida de precisión cuando los flujos $H$ y $\lambda E$ se hacen aproximadamente iguales y de signo contrario. En ese caso $\beta$ tiende a $-1(\beta=H / \lambda E)$, y la Ec. 4 tiende a infinito, lo que obliga a descartar a efectos de cálculo los periodos en que esto sucede. Este hecho generalmente ocurre en momentos del día cuando los flujos $H$ y $\lambda E$ suelen ser pequeños y de signo contrario (al amanecer, a la caída del sol y durante la noche). Para obviar el problema y descartar aquellos periodos en los que esto sucede, se puede recurrir a excluir aquellos valores de $\beta$ comprendidos en un intervalo fijo $(\beta<-0,75$ ó bien $-1,3<\beta<-0,7)$ independientemente de los errores cometidos en la medida de las variables que la definen (Ortega-Farias et al., 1996; Unland et al., 1996). No obstante, en este trabajo se ha preferido seguir a Pérez et al. (1999) quienes, definen un intervalo de exclusión variable de $\beta$ en función de la exactitud de las medidas.

\subsection{Condiciones advectivas durante el ensayo}

Un fenómeno observado en superficies agrícolas de zonas áridas, principalmente en cultivos y superficies vegetales de porte bajo es la advección local en la tasa de evapotranspiración (Priestley y Taylor, 1972; Leite et al., 1990; Jiyane y ZermeñoGonzález, 2003). Este fenómeno es resultado de un desplazamiento de masas de aire caliente y seco de los alrededores (superficies secas y calientes) hacia el interior de la parcela y que afecta al flujo de ET (Tolk et al., 2006). Lee et al. (2004) mencionan que el flujo de $E T$ de cultivos bien regados puede exceder la radiación neta, por el exceso de energía, proporcionado por una advección de calor sensible proveniente de campos adyacentes secos. Esto conlleva que cuando en una determinada localidad exista un efecto de advección local en la tasa de $E T$, el flujo de calor latente debe ser multiplicado por un factor de advección que permita la evapotranspiración real (Priestley y Taylor, 1972; Pérez y Castellví, 2002; Jiyane y Zermeño-González, 2003). Figuerola y Berliner (2005) proporcionan en su estudio una descripción más detallada del proceso de evapotranspiración bajo condiciones advectivas, y Gavilán y Berengena (2007) analizan la influencia de este fenómeno en la precisión del método RBBE para medir la $E T$ en climas advectivos semiáridos.

Pese a que difiere del objetivo principal del estudio, el análisis de este fenómeno resulta necesario para comprender las diferencias de los flujos de $\lambda E$ proporcionados por la metodología FAO-56 y el método RBBE respecto al lisímetro. La intensidad de advección se cuantificó mediante el empleo de un coeficiente de fracción de evaporación 
o 'Índice de Advección' (AI), que se calculó como la relación entre $\lambda E$ y $\left(R_{n}-G\right)$ (Todd et al., 2000), siendo $\lambda E$ el flujo de calor latente medido por el lisímetro y expresado en términos de energía $\left(\mathrm{W} \cdot \mathrm{m}^{-2}\right), R_{n}$ la radiación neta $\left(\mathrm{W} \cdot \mathrm{m}^{-2}\right)$ y $G$ el flujo de calor en el suelo $\left(\mathrm{W} \cdot \mathrm{m}^{-2}\right)$. La presencia del fenómeno de advección se evidencia con un índice de advección superior a la unidad (Priestley y Taylor, 1972), y cuanto mayor sea su valor, mayor será el aporte de calor sensible que contribuye a aumentar el flujo de ET.
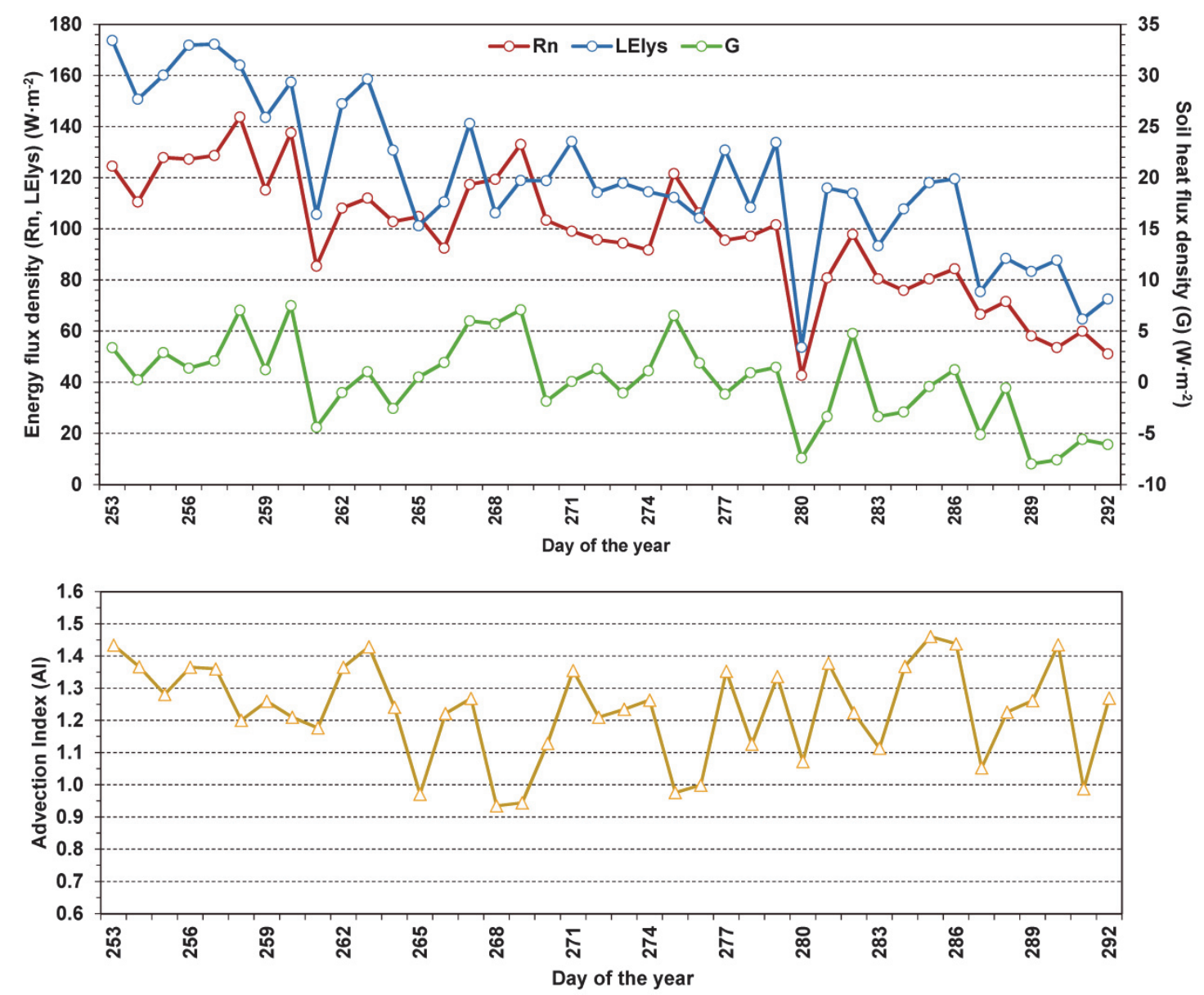

Fig. 5.4. Componentes del balance de energía e índice de advección durante el ensayo: radiación neta $\left(R_{n}\right)$, flujo de calor en el suelo $(G)$, evapotranspiración del lisímetro $\left(L E_{l y s}\right)$, e índice de advección $(\mathrm{AI})[\mathrm{AI}=$ $\left.L E_{l y s} /\left(R_{n}-G\right)\right]$.

\section{RESULTADOS Y DISCUSIÓN}

\subsection{Cuantificación de la advección de calor sensible}

La Fig. 5.4 muestra los componentes del balance de energía en la superficie. Para detectar la presencia de advección local, se ha incluido el 'Índice de Advección' (AI) medio diario. El análisis del balance de energía evidenció un proceso de advección de calor sensible, el cual se produjo casi a diario. Del total de los 40 días de estudio, 34 días ( $85 \%$ del periodo 
de estudio) resultaron ser advectivos, obteniéndose valores del AI superiores a 1,20 en 27 días. Este fenómeno fue más severo en los días 253, 263, 285, 286 y 290, con valores obtenidos superiores a 1,40 (Fig. 5.5). Esto significa que, aproximadamente, el 40\% de la energía utilizada para la evaporación es aportada por el calor advectivo. Debido a que el lisímetro estaba situado en el centro de la parcela, el 'fetch' fue superior a 49,5 m independientemente de la dirección del viento. Por consiguiente, es razonable suponer que el proceso advectivo predominantes es de naturaleza regional.
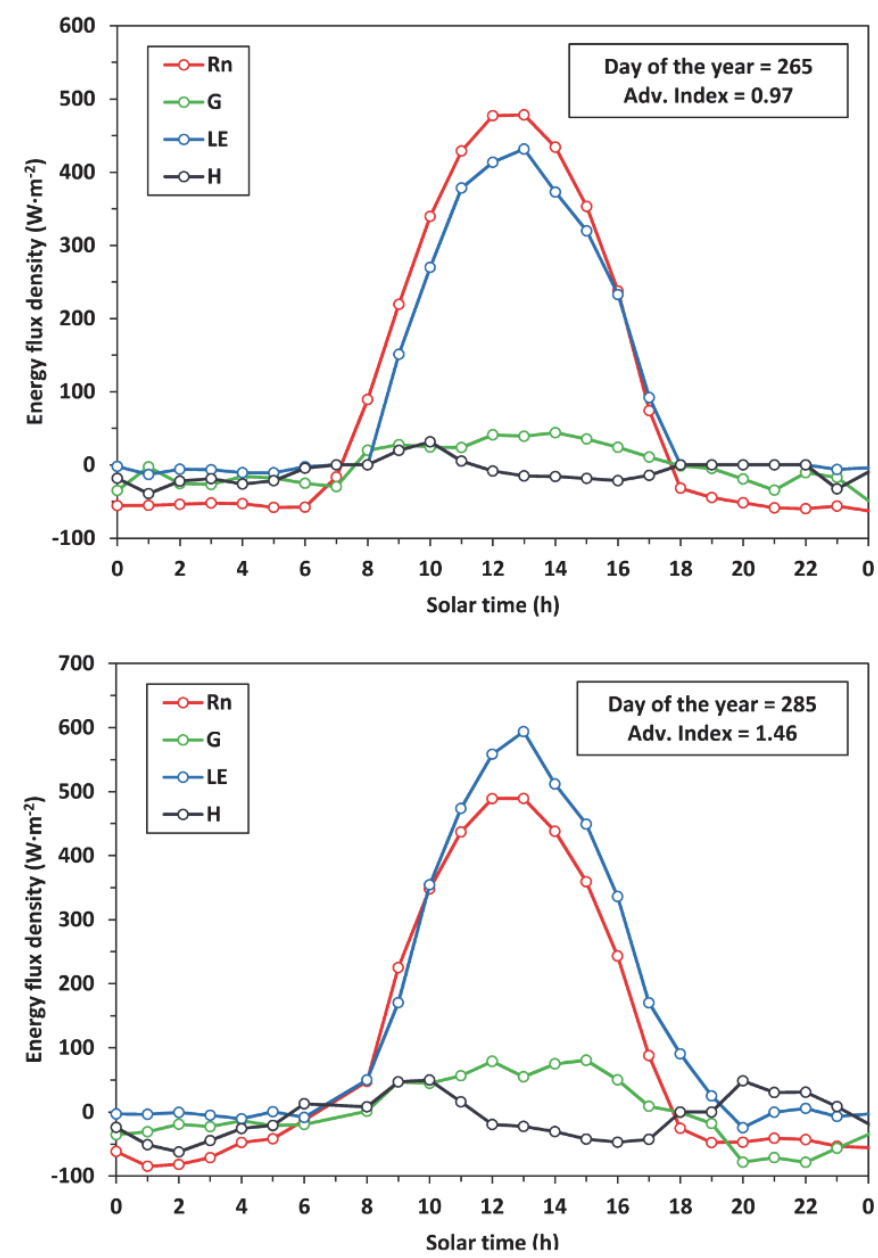

Fig. 5.5. Componentes del balance de energía durante 2 días del ensayo: radiación neta $\left(R_{n}\right)$, flujo de calor en el suelo $(G)$, flujo de calor latente $(L E)$, y flujo de calor sensible $(H)$.

\subsection{Definición de periodos rechazados}

De acuerdo con el procedimiento descrito por Pérez et al. (1999), la Fig. 5.6 muestra las frecuencias de rechazo de cada uno de los periodos horarios durante los 40 días de ensayo, para cada uno de los dispositivos empleados para calcular los gradientes de temperatura requeridos por el métodos RBBE (TMPs y RTDs). En ambos casos, durante el periodo 
de horas centrales del día (en el que se produce la mayor parte de la evapotranspiración) la frecuencia de horas rechazadas es prácticamente nula.

Como puede observarse en la Fig. 5.6, a partir de las 18:00 (hora solar) coincidiendo con el atardecer, la frecuencia de rechazo empieza a aumentar para situarse en un máximo de 0,58 para los TMPs y 0,70 para los RTDs a las 20:00 (hora solar), y luego osciló durante la noche. El cómputo acumulado de las horas excluidas supone un 21,7\% para el caso de los TMPs y un 20,5\% para los RTDs, obteniéndose un 9,8\% y 9,3\% para los valores diurnos y un $30,2 \%$ y $28,6 \%$ para los valores nocturnos, respectivamente. Estos valores son muy similares en ambos casos, y tienen un patrón de distribución muy similar.
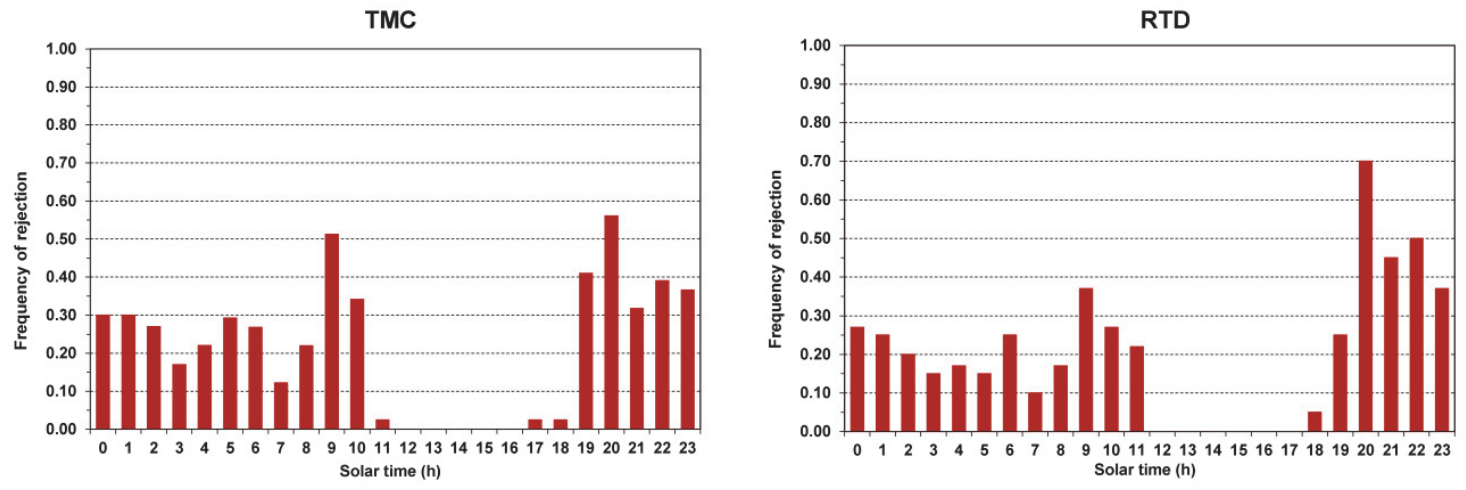

Fig. 5.6. Frecuencias de rechazo para diferentes horas del día y para ambos dispositivos empleados en el método RBBE.

En ambos casos, la frecuencia de rechazo comienzan al atardecer (18:00-19:00), prolongándose a lo largo de la noche hasta el amanecer (7:00-8:00). Estos resultados demuestran que la imprecisión del método RBBE es independiente del dispositivo de medida de temperatura empleado en la determinación de $\beta$, ya que en ambos casos tiene lugar el mismo fenómeno.

\subsection{Comparación de los valores de $E T$ entre el lisímetro y la ecuación FAO-56 y el método RBBE}

Considerando que las medidas del lisímetro de pesada corresponden exclusivamente a ganancias o pérdidas de agua, éste se utilizó como patrón para evaluar los valores de $E T$ estimados por la ecuación FAO-56 y los obtenidos con el sistema RBBE, usando tanto TMPs como RTDs. Las comparaciones se realizaron para periodos horarios, pues las limitaciones derivadas de la resolución del lisímetro aconsejaron no utilizar intervalos más cortos. La Fig. 5.7 muestra, a modo de ilustración, la evolución de los valores horarios de ET medidos por el lisímetro (ETLYS), estimados por la metodología FAO-56 


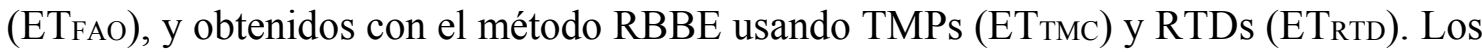
días mostrados en la figura fueron seleccionados como representativos del periodo de estudio en función del 'Índice de Advección'. El resto de días analizados mostraron un patrón similar.
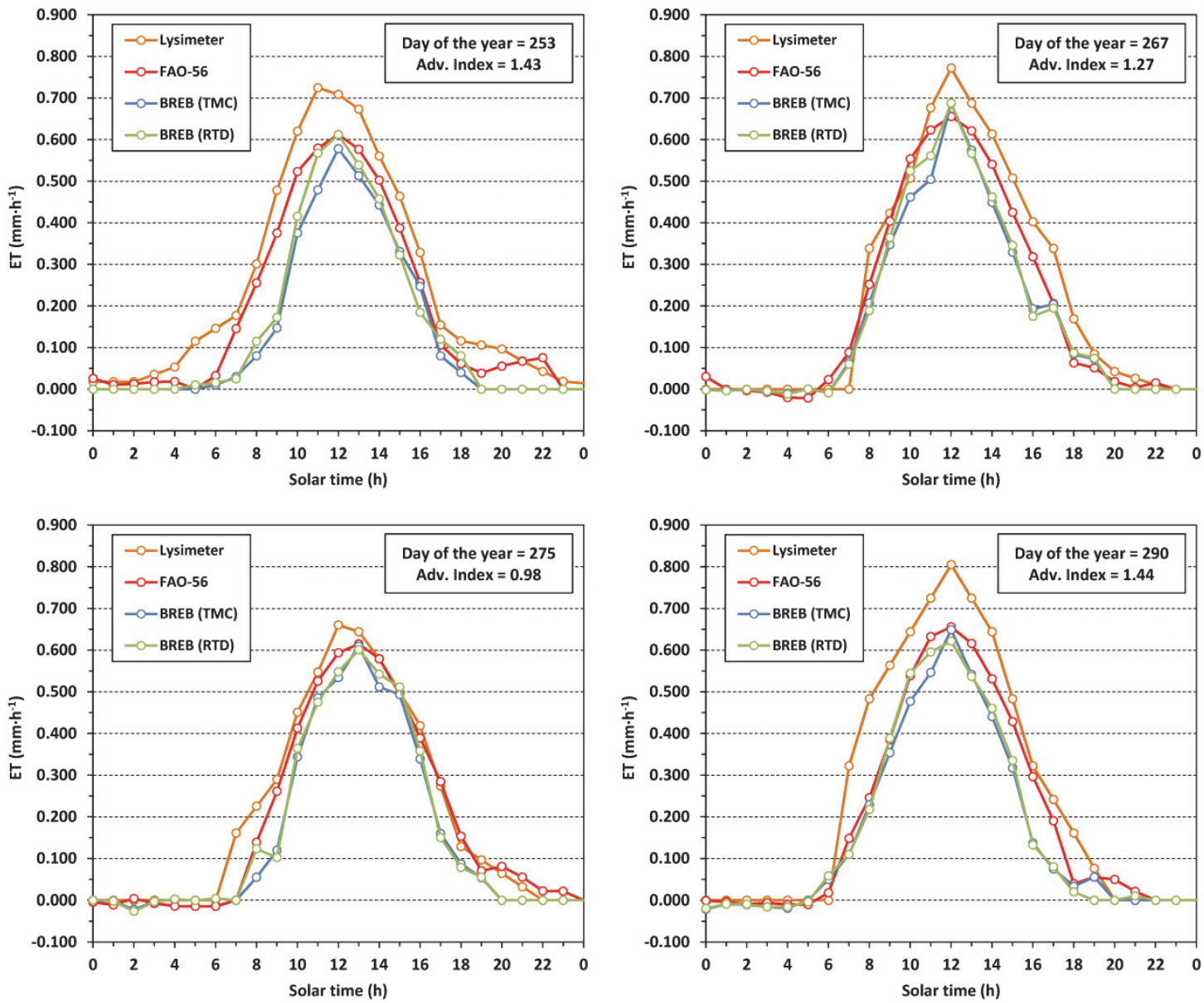

Fig. 5.7. Evolución de los valores horarios de ET durante 4 días representativos del ensayo, medidos por el lisímetro, estimados por la metodología FAO-56, y calculados con el método RBBE usando TMPs y RTDs.

En un primer análisis (Fig. 5.8), se compararon los valores horarios de ET estimados por la metodología FAO-56 y los obtenidos por el método RBBE usando TMPs y RTDs con los valores de ET medidos por el lisímetro. El análisis de regresión lineal realizado entre los valores horarios de ET estimados por la metodología FAO-56 (ETFAO) y los valores de ET medidos por el lisímetro (ETLYS) mostró que la ecuación de PenmanMonteith FAO-56 tendió a subestimar la evapotranspiración un 13,1\%, como se evidenció por la pendiente de la recta de regresión lineal igual a 0,869 (Fig. 5.8a). Resultados similares fueron obtenidos para cebada por López-Urrea et al. (2006b), quienes encontraron que la metodología FAO-56 subestimó un 14\% la evapotranspiración del cultivo medida por el lisímetro. Esta subestimación fue mayor para valores superiores 
a $0,300 \mathrm{~mm} \cdot \mathrm{h}^{-1}$ (Fig. 5.8a). El coeficiente de correlación obtenido no resultó significativamente diferente de la unidad $(0,960)$, y la ordenada en el origen no lo fue de cero $(0,013)$. La raíz del error cuadrático medio (RMSE) fue de $0,043 \mathrm{~mm} \cdot \mathrm{h}^{-1}$, resultando ser superior que la resolución del lisímetro $\left(0,040 \mathrm{~mm} \cdot \mathrm{h}^{-1}\right)$.
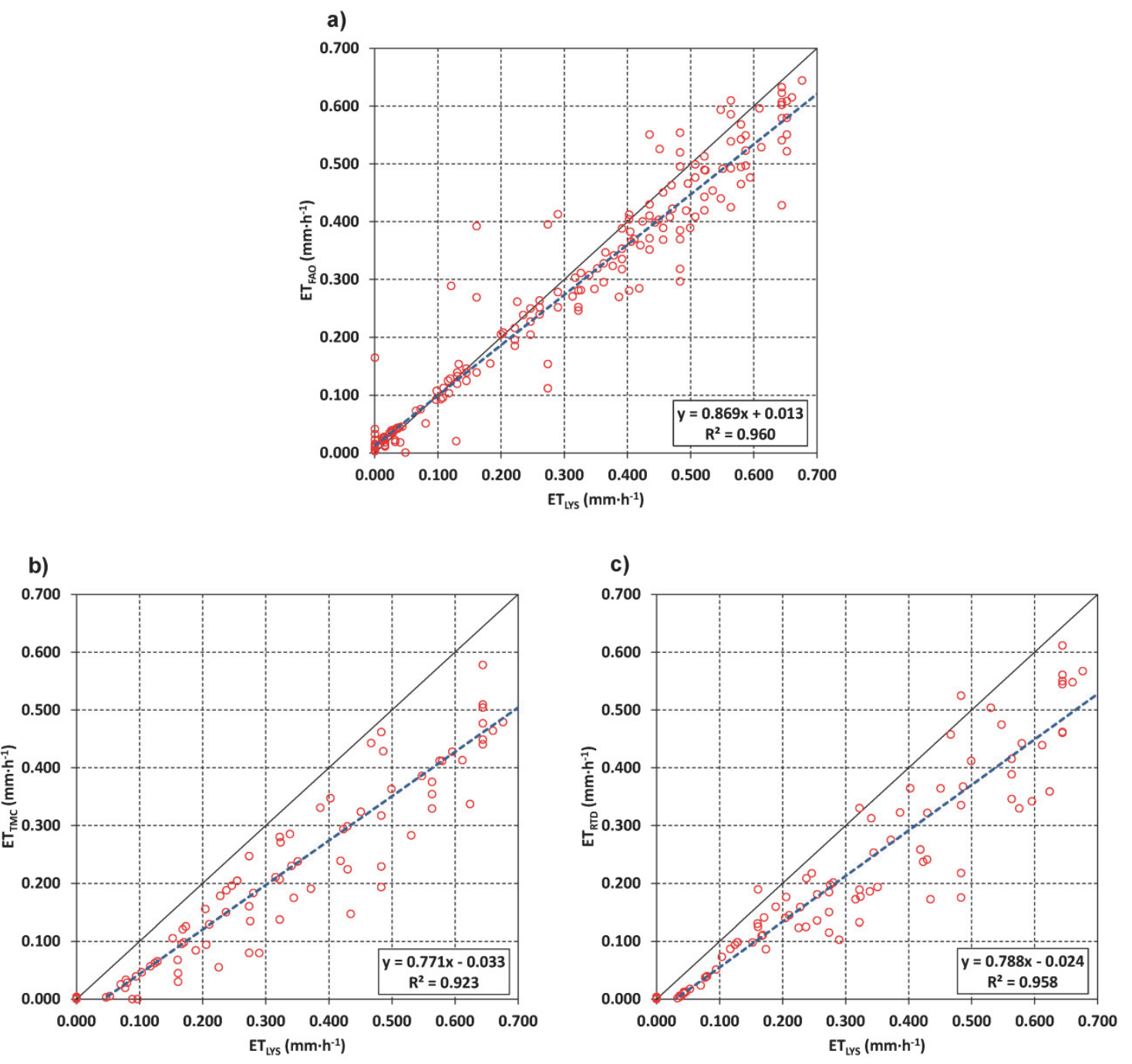

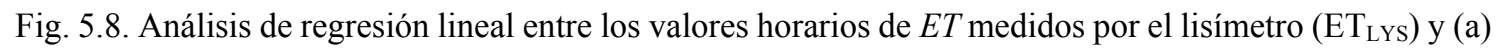
los valores horarios de ET estimados aplicando la ecuación de Penman-Monteith FAO-56 (ET FAO), (b) los valores horarios de $E T$ obtenidos con el método RBBE usando TMPs (ET $\mathrm{TMC}_{\mathrm{TMC}}$ ), y (c) los valores horarios de ET obtenidos con el método RBBE usando RTDs (ET $\left.\mathrm{RTD}_{\mathrm{R}}\right) . R^{2}$ representa el coeficiente de correlación.

Se ha demostrado que la similitud entre los valores de ET obtenidos por el lisímetro y los valores de ET calculados con la ecuación de Penman-Monteith FAO-56 (Allen et $a l ., 1998)$ disminuye a medida que aumenta la velocidad del viento (Lecina y MartínezCob, 2000). En condiciones de alta demanda evaporativa (en su mayoría los días de sol durante el verano), se espera que las tasas de ET aumenten aún más en condiciones de mucho viento. En estas situaciones, la ecuación de Penman-Monteith con un valor fijo de 
resistencia de la cubierta vegetal $\left(r_{c}=70 \mathrm{~s} \cdot \mathrm{m}^{-1}\right)$ resultó incapaz de representar adecuadamente el flujo de vapor de agua desde los cultivos a la atmósfera y tendió a subestimar la ET (Rana et al., 1994; Steduto et al., 1996; Pereira et al., 1999; Todorovic, 1999; Ventura et al., 1999; Lecina et al., 2003).

Se realizó un análisis de regresión lineal entre los valores horarios de ET medidos por el lisímetro (ETLYS) y los valores de ET obtenidos por el método RBBE (ETTMP y

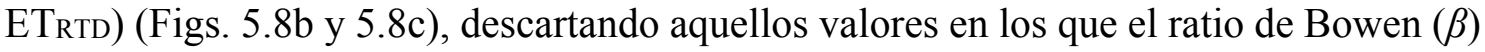
entró en el intervalo de exclusión. Los resultados indican una evolución similar de los valores calculados por ambos sistemas (TMPs y RTDs). El análisis mostró que ETLYs fue claramente subestimada por el método RBBE durante todos los días analizados, especialmente en aquellos en los que el fenómeno de advección fue más severo y durante las últimas horas de la tarde (patrones similares se observaron en el resto de días analizados). Estos resultados coinciden con los obtenidos por Dunin et al. (1991) y Prueger et al. (1997), quienes encontraron que el método RBBE tiende a subestimar las medidas lisimétricas de ET bajo condiciones advectivas.

Los valores horarios de $E T$ obtenidos por el método RBBE usando TMPs (ETTMC) también subestimaron un 22,9\% los valores de ET medidos por el lisímetro, como se evidenció por la pendiente de la recta de regresión lineal igual a 0,771 (Fig. 5.8b). Esta subestimación fue ligeramente inferior para las RTDs (21,2\%), obteniéndose una pendiente de la recta de regresión lineal igual a 0,788 (Fig. 5.8c). Los coeficientes de correlación obtenidos fueron 0,923 para los TMPs y 0,958 para los RTDs. En ambos casos, la ordenada en el origen (-0,033 para TMPs y $-0,024$ para RTDs) no resultó significativamente diferente de cero. La raíz del error cuadrático medio obtenida fue $0,042 \mathrm{~mm} \cdot \mathrm{h}^{-1}$ para los TMPs y $0,045 \mathrm{~mm} \cdot \mathrm{h}^{-1}$ para los RTDs. No obstante, el empleo de RTDs mostró mejores resultados que los TMPs en la estimación de ET con el método RBBE, atribuible a la mayor precisión y estabilidad de los RTDs (casi diez veces mayor).

\subsection{Comparación de los valores de ET entre TMP y RTD}

Los valores de ET obtenidos por el método RBBE usando TMPs (ETTMC) y RTDs (ETRTD) fueron comparados para demostrar la posibilidad de sustituir los TMPs instalados en las actuales estaciones Bowen por RTDs. La Fig. 5.9 muestra el análisis de regresión lineal realizado entre los valores horarios de $E T$ obtenidos por el método RBBE usando TMPs y RTDs para varios días representativos del ensayo. El análisis realizado mostró la gran 
similitud entre los valores estimados, sin tener en cuenta la sonda de temperatura empleado en el sistema Bowen. En todos los casos, los coeficientes de correlación fueron superiores a 0,985 y los valores de RMSE oscilaron en el intervalo 0,016-0,023 $\mathrm{mm} \cdot \mathrm{h}^{-1}$. Sin embargo, ETтмC subestimó ligeramente a ETRTD en todos los días analizados, como evidenció la pendiente de la recta de regresión lineal diferente a la unidad (Fig.5.9). ET TMC subestimó una medio del 4,4\% los valores de ET RTD, y subestima aún más las medidas lisimétricas de $E T$ (Figs. $5.8 \mathrm{~b}$ y $5.8 \mathrm{c}$ ).
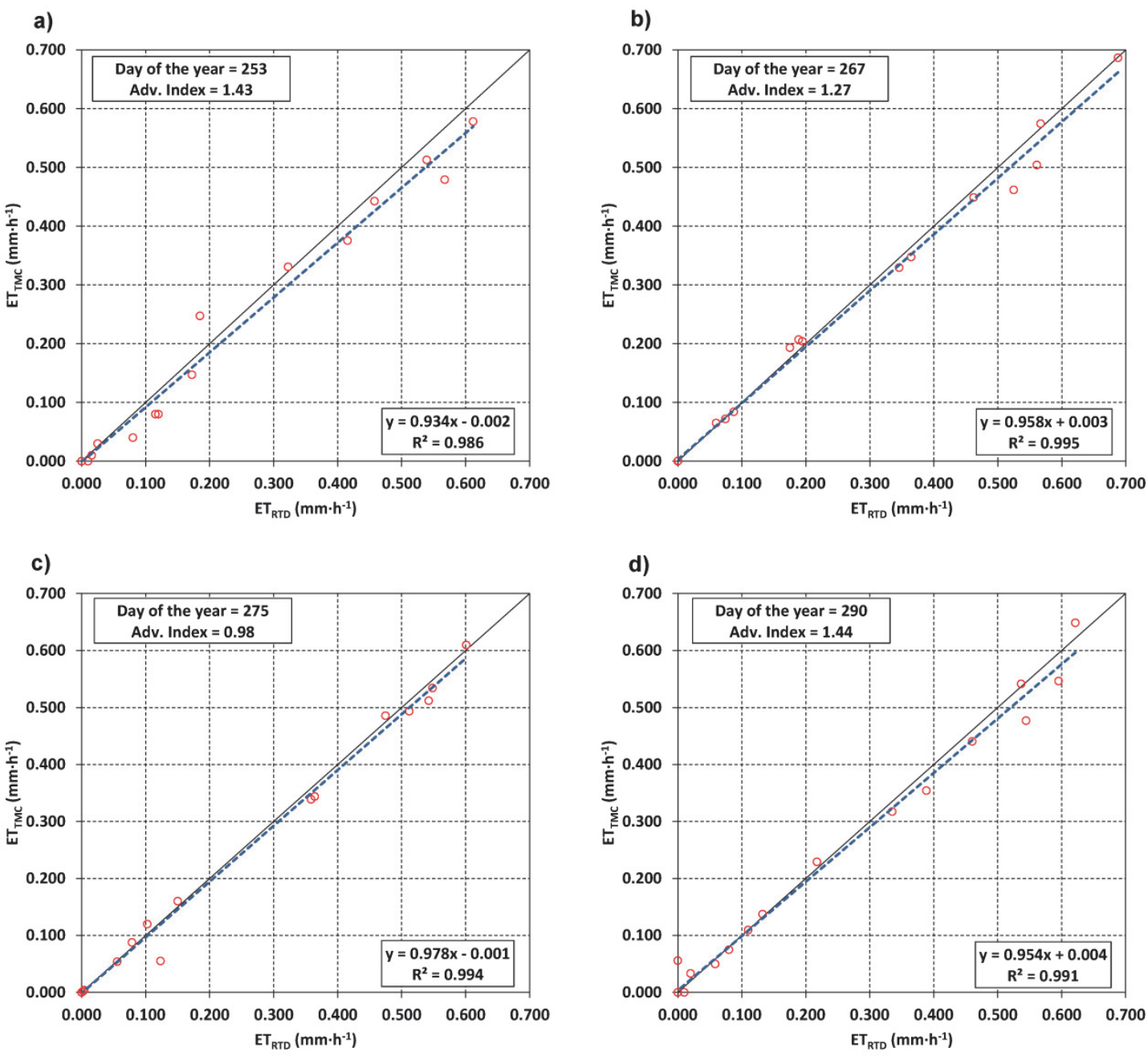

Fig. 5.9. Análisis de regresión lineal para 4 días representativos del ensayo entre los valores horarios de $E T$ estimados con el método RBBE usando TMPs (ET $\mathrm{TMC}_{\mathrm{TMC}}$ y RTDs (ET $\left.\mathrm{RTD}_{\mathrm{RT}}\right) R^{2}$ representa el coeficiente de correlación.

Por tanto, el sistema Bowen utilizando RTDs proporcionó el mejor ajuste a los valores de ET medidos por el lisímetro (Fig. 5.8c), lo que justifica la mayor idoneidad de los RTDs para su empleo en los sistemas Bowen para estimar la evapotranspiración. Sin embargo, la mayor limitación de los resultados obtenidos es el corto periodo de tiempo 
registrado (sólo 40 días al final de verano, cuando la ET es relativamente baja), por lo que se recomienda ampliar el periodo comparativo para asegurar la calidad de los resultados, incluyendo periodos de mayor demanda evaporativa de la atmósfera.

\section{CONCLUSIONES}

El estudio realizado en este artículo permitió determinar la evapotranspiración de un cultivo de referencia empleando tres metodologías diferentes: lisimetría, ecuación de Penman-Monteith FAO-56 y método RBBE. Además, el método RBBE fue aplicado empleando un sistema Bowen equipado con diferentes sensores para la medida de los gradientes de temperatura (TMPs y RTDs). Basado en los análisis y comparaciones realizados en este estudio, los valores de ET medidos por el lisímetro fueron subestimados en torno a un $13,1 \%$ por la ecuación de Penman-Monteith; este comportamiento puede atribuirse al error introducido suponiendo un valor fijo de resistencia de la cubierta vegetal $\left(r_{c}=70 \mathrm{~s} \cdot \mathrm{m}^{-1}\right)$ a lo largo de todo el día. Sin embargo, la metodología FAO-56 proporcionó el mejor ajuste a los valores de ET proporcionados por el lisímetro, obteniéndose un coeficiente de correlación de 0,960.

El método RBBE también subestimó los valores de ET del lisímetro, debido al fenómeno de advección detectado que anula la hipótesis de similitud entre los coeficientes de transporte turbulento. Aunque la comparación entre el método RBBE usando TMPs y RTDs no proporcionó diferencias significativas entre los dos dispositivos, como mostraron los coeficientes de correlación superiores a 0,985 , los TMPs proporcionaron una ligera subestimación de los valores de ET medidos por el método RBBE usando RTDs (4,4\%). El sistema Bowen usando TMPs subestimó en torno a un 22,9\% los valores de ET medidos por el lisímetro, y el mismo sistema usando RTDs, un 21,2\%. En este caso, los RTDs denotaron una mayor similitud con los valores lisimétricos de ET, obteniéndose un coeficiente de correlación de 0,958 en comparación con los TMPs $(0,923)$. No se observaron pérdidas de precisión como consecuencia del autocalentamiento de los RTDs.

Los resultados presentados en este trabajo sugieren la posibilidad de sustituir los TMPs instalados en las actuales estaciones Bowen por RTDs. En adición a lo expuesto, los RTDs presentan una serie de ventajas funcionales frente a los TMPs. Por ejemplo, los RTDs presentan una mayor simplicidad de instalación, así como un menor coste de mantenimiento a largo plazo, pues se presentan como un instrumento más robusto que 
apenas requiere mantenimiento. En cambio, los TMPs requieren una mayor frecuencia de mantenimiento e inspección para comprobar el correcto funcionamiento de los ventiladores (que hacen circular un flujo continuo de aire a través del tubo donde suelen ir instalados los termopares) y grado de limpieza de los filtros instalados en los tubos. Además, los RTDs son dispositivos más robustos y duraderos, mientras que la extremada delgadez y fragilidad de los TMPs los hacen susceptibles a la rotura y obliga a protegerlos de agentes externos. 


G Model
AGWAT-4001; No.of Pages 12

Agricultural Water Management xxx (2014) xxx-xxx

Contents lists available at ScienceDirect

Agricultural Water Management

journal homepage: www.elsevier.com/locate/agwat

\title{
Selection of device to determine temperature gradients for estimating evapotranspiration using energy balance method
}

\author{
D. Escarabajal-Henarejos ${ }^{\text {a,*, D.G. Fernández-Pacheco }}{ }^{\text {b }}$, J.M. Molina-Martínez ${ }^{\text {a }}$,
} L. Martínez-Molina ${ }^{\mathrm{c}}, \mathrm{A}^{\text {. Ruiz-Canales }}{ }^{\mathrm{d}}$

a Research Group in Agromotic Engineering and the Sea, Technical University of Cartagena, Cartagena 30203, Spain ${ }^{\mathrm{b}}$ Graphical Expression Department, Technical University of Cartagena, Cartagena 30202, Spain

c Provincial Technical Institute of Agriculture in Albacete (ITAP), Albacete 02080, Spain

¿ Engineering Department, Miguel Hernández University of Elche, Orihuela 03312, Spain

A R T I C L E I N F O

\section{Article history:}

Received 4 April 2014

Received in revised form 7 September 2014 Accepted 9 September 2014

Available online $\mathrm{xxx}$

Keywords:

Bowen-ratio system

Bowen-ratios

Penman-Monteith equation

Local advection

\begin{abstract}
A B S T R A C T
Among the methodologies that analyze the energy and mass exchange during the evapotranspiration process, the micrometeorological methods provide one of the best tools to elaborate models and to understand the interaction process between crop and environment. Concretely, the Bowen ratio-energy balance (BREB) method has been used by several authors in the literature to estimate crop evapotranspiration in real time, obtaining accurate results. In order to calculate evapotranspiration, this method requires obtaining average temperature gradients over vegetation cover, which are measured in commercial equipment by the aid of thermocouples (TMCs). However, an alternative to the use of these thermometric gauges is the utilization of resistance temperature detectors (RTDs). These sensors present improvements of accuracy, tolerance and stability, among others, against TMCs. The present paper assess the employment of both thermometric gauges (TMCs and RTDs) when estimating evapotranspiration by using the BREB method. For this purpose, the evapotranspiration of a reference crop (Festuca arundinacea $\mathrm{L}$. cv Schreb.) was determined by means of a weighing lysimeter and estimated with FAO-56 Penman-Monteith equation and BREB method, using for this last both TMC and RTD sensors for obtaining average temperature gradients. The results of the comparative analysis between the ET values measured by the lysimeter and the ET values obtained using the BREB method denote a greater similarity, obtaining a correlation coefficient of 0.958 when using RTDs and of 0.923 with TMCs. The ET values calculated using TMCs and RTDs were also compared with each other to estimate the degree of similarity between them. The results did not show significant differences, obtaining for all analyzed days a squared correlation coefficient above 0.985 .

(c) 2014 Elsevier B.V. All rights reserved.
\end{abstract}

\section{Introduction}

Evapotranspiration (ET) can be defined as the process in which water is transferred from terrestrial surface to the atmosphere (Doorenbos and Pruitt, 1977). ET not only includes the liquid or solid water evaporation process directly from soil, water layers or plant surfaces, but also takes into account the water losses due to the physical and biological transpiration process carried out in stomata of plant leaves (Jensen et al., 1990). Both processes consider the state change from liquid to vapor. With regard to the evaporation process, it depends essentially on climatic conditions. However,

\footnotetext{
* Corresponding author. Tel.: +34 9683259 29; fax: +34 968327031.

E-mail address: david.escarabajal@gmail.com (D. Escarabajal-Henarejos).

http://dx.doi.org/10.1016/j.agwat.2014.09.011

0378-3774/O 2014 Elsevier B.V. All rights reserved.
}

transpiration is a more complex process which can be influenced by factors of a physiological and aerodynamic nature associated to different vegetal species, and can be limited by water availability (Fernández García, 1995).

In nature, both processes occur simultaneously and it is not easy to estimate how much water vapor is lost in each of them. For this reason the concept of evapotranspiration is used instead, considering it as a whole loss of a particular system (Allen et al., $1998,2007)$. Evapotranspiration is a phenomenon of great interest in several disciplines and one of the most difficult to quantify and to measure experimentally (Cui and Zornberg, 2008), what has led to the development of multitude of methods, techniques and empirical equations for obtaining more exact and precise estimations (Cancela et al., 2006; Gocic and Trajkovic, 2010, 2011; Fernández-Pacheco et al., 2014). This quantification of 


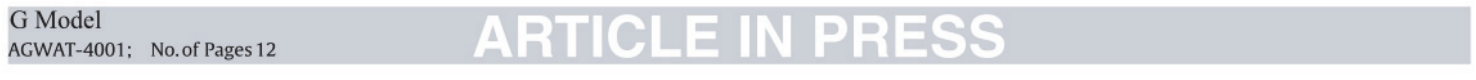

evapotranspiration is important for irrigation management or irrigation scheduling (Aydin, 2008; Fandiño et al., 2012).

Advances in evapotranspiration estimation are derived from the introduction of the concept of potential evapotranspiration (PET) by Penman (1948) and Thornthwaite (1948). This concept expresses more precisely the maximum water transfer ratio between the terrestrial surface and the atmosphere. The Thornthwaite's calculation method has been widely used because of its simplicity and the use of data easily obtained from conventional weather stations. Nevertheless, this method has been demonstrated to underestimate ET in arid zones and overestimate it in humid climates (Ahmadi and Fooladmand, 2008). Moreover, the method requires to be recalibrated if climatic conditions change (Al-Ghobari, 2000). Various decades later, Doorenbos and Pruitt (1977) defined a new concept of 'reference evapotranspiration', establishing new objectives to be covered in the new researching lines.

There exists a wide variety of methods for estimating ET (Itier, 1996; Rana and Katerji, 2000; Allen et al., 2011a,b), and the use of one method or another depends on the accuracy requested and the cost of the measurements. In order to summarize the different methods for estimating ET, several authors distinguish between direct and estimation methods (Maidment, 1992). Other classifications are proposed by Jensen et al. (1990), Martin de Santa Olalla and de Juan (1993) and Rosenberg et al. (1983), who make a classification based on the soil water balance, climatological parameters, or micrometeorological parameters, respectively.

Direct methods are water-based and calculate ET for a determined time interval as the difference between the contribution of water by precipitation or irrigation and the amount of water drained, which can be measured using lysimeters (Kirkham et al., 1991). A detailed summary of the use of lysimeters for ET calculation can be found in publications by Harrold et al. (1966), Aboukhaled et al. (1982), Howell et al. (1985), Marek et al. (1988), and Pruitt and Lourence (1985). Lysimeters have been extensively used to provide baseline information for development, calibration, and validation of ET methods (Makkink, 1957; Jensen, 1974; Doorenbos and Pruitt, 1977; Wright, 1981, 1982; Allen et al., 1989; Jensen et al., 1990; Unlu et al., 2010).

Although different methods for estimating ET have been proposed by several authors, there is still no consensus about which method is the most appropriated for each climate, also requiring strict local calibrations (DehghaniSanij et al., 2004; Ahmadi and Fooladmand, 2008). The classification proposed by Rosenberg et al. (1983) included a group named "micrometeorological" in which ET was estimated in short time intervals (less than $30 \mathrm{~min}$ ), what allowed to calculate this parameter in real time. Among these micrometeorological methods are the following: Eddy covariance (EC) (Shaw et al., 2003; Meyers and Baldocchi, 2005), aerodynamic method (Rana et al., 1990), scintillometry (Hartogensis et al., 2003; De Bruin, 2008), and Bowen ratio-energy balance (BREB) method (Bowen, 1926). Concretely, the BREB method permits to obtain good results in estimation of crop evapotranspiration in real time and requires equipment than can be easily obtained in comparison with other existing methods as Eddy covariance (Uddin et al., 2013) or lysimetry (Dicken et al., 2013). The method allows estimating evapotranspiration as a component of the energy balance by means of the Bowen-ratio (Bowen, 1926), which is based on air temperature and vapor-pressure gradients. It is a non-destructive method that does not require aerodynamic data and that can be automated using a Bowen-Campbell scientific system (Campbell Scientific, 1998).

The BREB method has been widely used to estimate water vapor flux on evaporation surfaces (Savage et al., 2009; Elsawwaf et al., 2010; Potter et al., 2011; Andreas et al., 2013; Peake et al., 2013) and has been applied to calibrate and validate the reference evaporation models, also at regional level (Xing et al., 2008; Zeggaf et al., 2008; Unlu et al., 2010; Bezerra et al., 2012; Uddin et al., 2013) and under advective conditions (Gavilan and Berengena, 2007). Balbontin-Nesvara et al. (2011) evaluated and compared the EC and BREB methods to estimate the daily ET in an irrigated vineyard located in the semiarid region of Tarazona de la Mancha (Spain), obtaining very similar values with practically negligible underestimations of the ET calculated using the BREB method against the EC method, what demonstrated the validity and accuracy of the BREB method.

The commercial equipment based on the BREB method that is currently used in research determines the temperature gradients by means of thermocouples (e.g. Cromo-Constatan). These thermocouples (TMCs) are protected against direct radiation and externa agents by means of aspirated pipes through which a constant air flux circulates. With regard to vapor pressure gradients, they are determined by a high precision hygrometer (e.g. mirror dew point hygrometer), which is supplied by an aspiration pump. These components have a high acquisition cost and require both constant maintenance and conservation procedures in order to ensure the reliability of the obtained measures. However, the existence in the market of gauges endowed with a metallic resistance temperature detector (RTD) and a capacitive humidity sensor allows obtaining the gradients required by the Bowen-ratio system utilizing a simplified, robust and low maintenance device (Fritschen and Simpson, 1982). Moreover, these temperature-humidity gauges present several advantages in comparison with conventional TMCs, such as low cost, high precision and better stability and linearity (Savage, 2010).

In this paper, a weighing lysimeter, FAO-56 Penman-Monteith equation and BREB method were used to determine evapotranspiration of a reference crop (Festuca arundinacea L. cv Schreb.), comparing later the values obtained by each method. Besides, a comparative analysis and evaluation of the performance of both systems (TMCs and RTDs) for determining the temperature gradients required by the Bowen-ratio method is developed in this article. The obtained results were compared with the values provided by the weighing lysimeter, demonstrating the suitability of RTDs to be used in the Bowen-ratio systems for measuring temperature gradients instead of the traditional TMCs.

\section{Materials and methods}

Three different methods were carried out in parallel to determine evapotranspiration from a reference crop (F. arundinacea $\mathrm{L}$. cv Schreb.): lysimetry, FAO-56 Penman-Monteith equation and BREB technique. And in particular for the BREB method, two different instruments (TMCs and RTDs) were employed to measure temperature gradients. In the following paragraphs a more detailed description of the study is accomplished.

\subsection{Experimental site}

Experimental work was conducted during a period of 40 days from September to October of 2011 in an experimental station at 'Las Tiesas' farm (latitude $39^{\circ} 3^{\prime} 37^{\prime \prime} \mathrm{N}$, longitude $2^{\circ} 6^{\prime} \mathrm{W}$ and altitude $695 \mathrm{~m}$ ) located in Albacete (Spain), and managed by the Provincial Technical Institute of Agriculture in Albacete (ITAP).

The climate of the zone is semi-arid, characterized by pronounced seasonal variation corresponding to its continental nature, with an average temperature of $4.5^{\circ} \mathrm{C}$ in the coldest month (January) and of $24-26^{\circ} \mathrm{C}$ in the hottest month (July). The mean annual temperature is approximately $13.7^{\circ} \mathrm{C}$ and the average annual rainfall is $320 \mathrm{~mm}$, mostly concentrated in the spring and fall. A more detailed description of the climate of the area is 


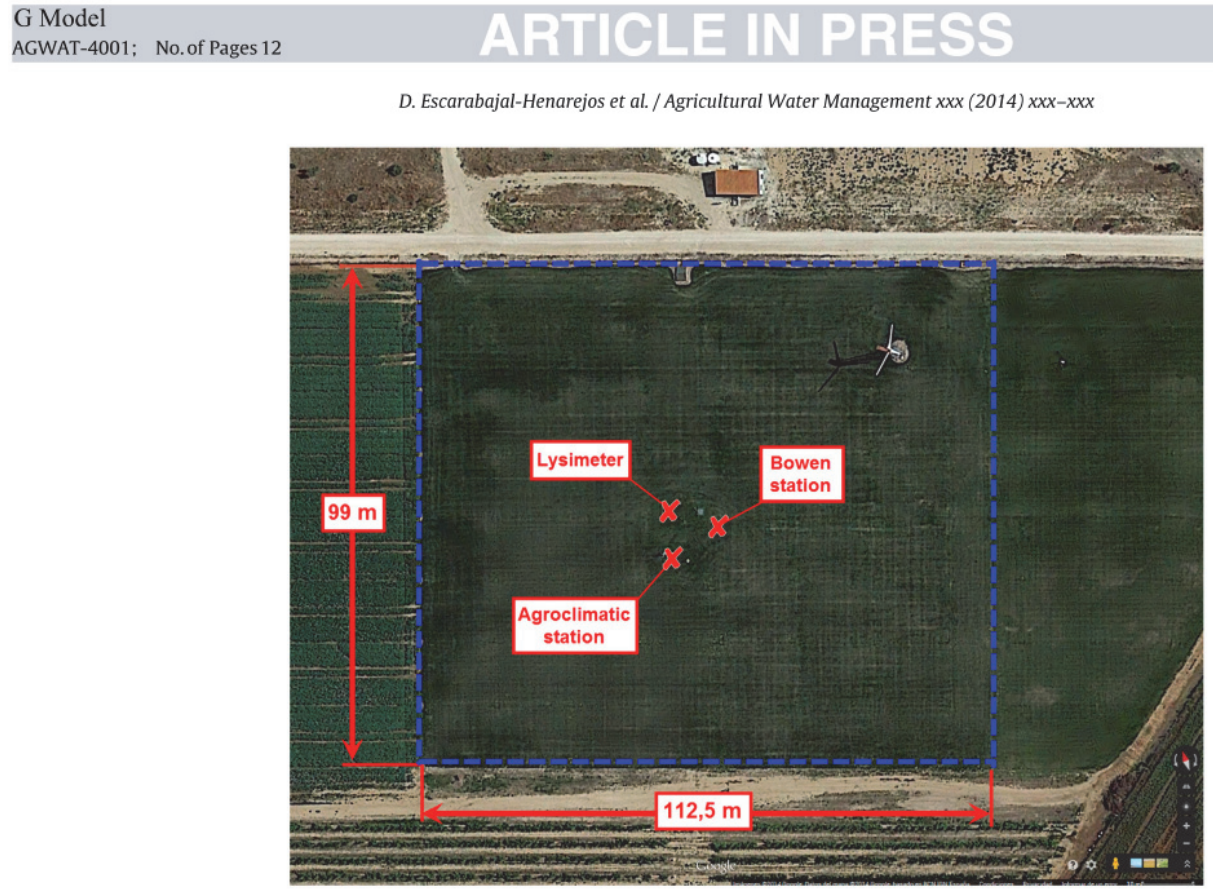

Fig. 1. Location of the lysimeter, the agroclimatic station and the Bowen station in the experimental plot.

provided by López-Urrea et al. (2006a). The Thornthwaite's agroclimatic classification (Thornthwaite, 1948) characterizes the local climate as semiarid (D), mesothermic (B'2), with a total lack of humidity (d), and with a moderate concentration of water demand in summer $\left(b^{\prime} 3\right)$

The soil is classified as "Petrocalcic Calcixerepts" (Baillie, 2001) and has an average depth of approximately $50 \mathrm{~cm}$, which is limited by the existence of a petrocalcic horizon that is more or less fragmented. The predominant texture is silty-clay-loam (sand: $13.4 \%$ silt: $48.9 \%$ and clay: $37.7 \%$ ). The soil has a basic $\mathrm{PH}$ and is poor in organic matter and nitrogen, having a high content of active limestone and potassium.

The study was performed on a 1.1 ha $(99.0 \mathrm{~m} \times 112.5 \mathrm{~m})$ leveled grass plot (F. arundinacea L. cv Schreb.), which is used as a reference surface for ET measurements. The plot was frequently mowed and sprinkler irrigated to meet the specifications of crop height and water status given for the reference crop. During the study, the height of the grass was always between 10 and $15 \mathrm{~cm}$, and there was no extra water on the canopy.

The plot was endowed with a weighing lysimeter with continuous electronic data recording, which permitted to execute reference evapotranspiration measurements, and an agroclimatic station placed about $10 \mathrm{~m}$ from the lysimeter, which permitted to determine ET by using FAO-56 methodology. Besides, a Bowen ratio station, which enabled to register the climate variables required for the BREB method, was placed inside the parcel. Fig. 1 shows the location of equipment in the experimental plot.

Climate conditions were very regular during the study period, with daily values of net radiation around $25 \mathrm{MJ} \mathrm{m}^{-2}$ day $^{-1}$ in the initial days of the study and $20 \mathrm{MJ} \mathrm{m}^{-2}$ day $^{-1}$ in the last days. Only days $261,266,267,268,272,273,274$ and 280 were cloudy. An average maximum temperature of $23.4^{\circ} \mathrm{C}$ and an average minimum temperature of $12.3^{\circ} \mathrm{C}$ were registered during the period. The mean daily wind speed, which was measured at $2 \mathrm{~m}$ from the ground level, varied between 1.04 and $3.98 \mathrm{~m} \mathrm{~s}^{-1}$. During the study, rainfalls were practically non-existent. Only a precipitation episode which supplied $8.85 \mathrm{~mm}$, was presented. The ET accumulated was of $163.27 \mathrm{~mm}$, obtaining an average value of $4.71 \mathrm{~mm} \mathrm{day}^{-1}$ during the first half of the period and of $3.45 \mathrm{~mm} \mathrm{day}^{-1}$ during the second half (see Fig. 2). This ET was mainly compensated with irrigation, which supposed a total water supply of $164.87 \mathrm{~mm}$ during the study.

\subsection{Weighing lysimeter}

In order to obtain the actual evapotranspiration measurements a weighing lysimeter with continuous electronic data recording was employed during the study. This system was also used with success by López-Urrea et al. (2006a, 2009a,b). The lysimeter was located in the center of the plot (see Fig. 1). The dimensions of the lysimeter tank were $2.7 \mathrm{~m} \times 2.3 \mathrm{~m}$, with a depth of $1.7 \mathrm{~m}$ and an approximate total weight of $14.5 \mathrm{t}$, and it was cultivated with the same specie $(F$. arundinacea $\mathrm{L}$. cv Schreb). The crop inside the lysimeter was kept at the same growth rate as the crop on the outside in order to minimize edge effects.

The lysimeter tank sits on a system of beams that reduces the load by 1000:1 and has a counterweight that offsets the weight of the soil and the tank. The balance system includes a steel load cell (model SB2, Epelsa Ind., S.L., Madrid, Spain) with a nominal capacity of $50 \mathrm{~kg}$, an excitation output range of $2 \mathrm{mVV}^{-1}$ and a power supply of $5 \mathrm{~V}$ at full load. This load cell was connected to an electronic monitor model SMART (UTILCELL, Barcelona, Spain) with a resolution of $250 \mathrm{~g}$, which is equivalent to $0.040 \mathrm{~mm}$ of ET. Hence, the lysimeter was provided with the necessary equipment to perform a complete water balance and to asses with accuracy both water supplies (rainfall and irrigation) and losses (evapotranspiration and deep drainage).

Weight data generated by the lysimeter and showed in the monitor were also stored in a CR10X datalogger (Campbell Scientific Spain Inc., CSI. Logan, UT, USA), which was programed to take readings every second and generate registers every 15 min during all the study period. Lysimeter readings were checked daily to identify individual readings that could not be explained by natural processes of water inputs and losses. For instance, some data losses occurred during irrigation and precipitation events, weight and calibration verifications, and when the cultivation of the soil inside 
G Model
AGWAT-4001; No.of Pages 12

4 D. Escarabajal-Henarejos et al. / Agricultural Water Management $x x x$ (2014) $x x x-x x x$
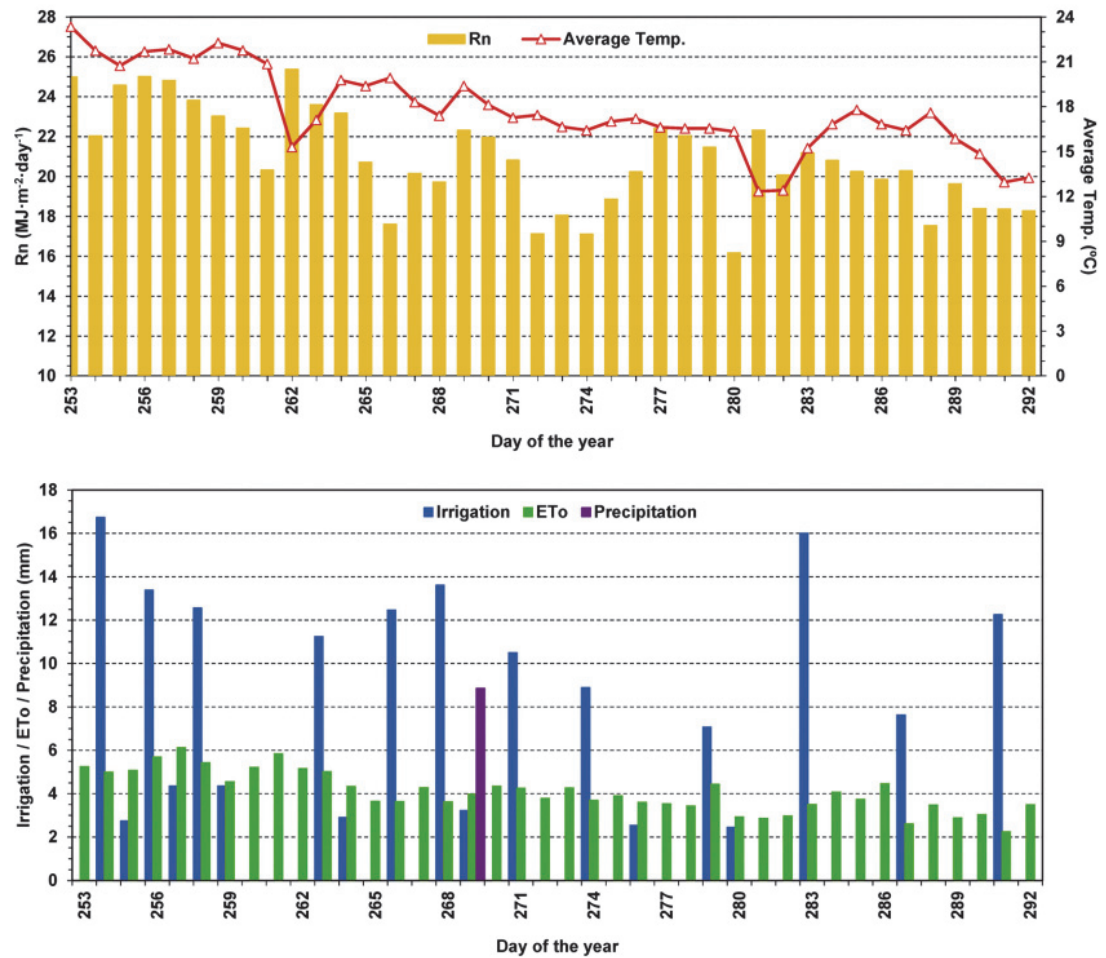

Fig. 2. Daily data recorded for net radiation $\left(R_{n}\right)$, average temperature, irrigation, reference evapotranspiration $\left(\mathrm{ET}_{0}\right)$ and precipitation during the experiment.

the lysimeter tank was performed. The resulting data was compiled to obtain a direct and precise measurement of $\mathrm{ET}_{0}$ under the climatic conditions of the area.

\subsection{FAO-56 Penman-Monteith equation}

In addition to the data provided by the lysimeter, evapotranspiration was also calculated using the FAO-56 Penman-Monteith equation (Allen et al., 1998):

$\mathrm{ET}_{0}=\frac{0.408 \Delta\left(R_{n}-G\right)+\gamma\left(37 /\left(T_{a}+273\right)\right) u_{2}\left(e_{s}-e_{a}\right)}{\Delta+\gamma\left(1+0.34 u_{2}\right)}$

where $\mathrm{ET}_{0}$ represents the hourly reference evapotranspiration $\left(\mathrm{mm} \mathrm{h}^{-1}\right), \Delta$ represents the slope vapor pressure curve $\left(\mathrm{kPa}^{\circ} \mathrm{C}^{-1}\right)$, $R_{n}$ is the net radiation at the crop surface $\left(\mathrm{MJ} \mathrm{m}^{-2} \mathrm{~h}^{-1}\right), G$ indicates the soil heat flux density $\left(\mathrm{MJ} \mathrm{m}^{-2} \mathrm{~h}^{-1}\right), \gamma$ is the psychrometric constant $\left(\mathrm{kPa}^{\circ} \mathrm{C}^{-1}\right), T_{a}$ is the mean air temperature at $2 \mathrm{~m}$ height $\left({ }^{\circ} \mathrm{C}\right)$, $u_{2}$ is the mean hourly wind speed at $2 \mathrm{~m}$ height $\left(\mathrm{m} \mathrm{s}^{-1}\right), e_{s}$ defines the saturation vapor pressure at air temperature $T_{a}(\mathrm{kPa})$ and $e_{a}$ indicates the actual vapor pressure $(\mathrm{kPa})$.

All meteorological data required by the equation were collected by the aid of a weather station that was placed on the reference crop and about $10 \mathrm{~m}$ from the lysimeter (see Fig. 1). The station was equipped with a CR10X datalogger (Campbell Scientific Spain Inc. CSI. Logan, UT, USA) and sensors for temperature and relative air humidity (MP100 probe, Campbell Scientific, Logan, UT, USA), solar radiation (CM14 pyranometer, KIPP\&ZONEN Delft, Holland), wind speed and direction (A100R anemometer and W200P windvane, Vector Instruments Ltd., UK), and rainfall (ARG100 pluviometer, Campbell Scientific Spain Inc., CSI. Logan, UT, USA). Concerning the temperature and humidity probe, it was placed at $1.5 \mathrm{~m}$ above ground level, while the wind sensors where located at $2.0 \mathrm{~m}$ height (see Fig. 3).

\subsection{Bowen ratio-energy balance method}

The BREB method was the third method chosen for estimating ET in this study. In this method, which is based on water vapor pressure and temperature gradients above the crop surface, two devices were used to determine temperatures: TMCs and RTDs. A comparative analysis of the results provided by both proceedings was performed. Every component of the energy balance at reference surface was determined using the following equation:

$R_{n}-G=\lambda E+H$

where $R_{n}$ is the net irradiance $\left(\mathrm{W} \mathrm{m}^{-2}\right), G$ is defined as the soil heat flux $\left(\mathrm{W} \mathrm{m}^{-2}\right), \lambda E$ represents the latent-heat flux $\left(\mathrm{W} \mathrm{m}^{-2}\right)$, that's to say, evapotranspiration, and $H$ indicates the sensible-heat flux $\left(\mathrm{W} \mathrm{m}^{-2}\right)$. All climate and weather variables implicated in the BREB method were registered and processed by an equipment powered by solar panels and a battery, and placed in the experimental plot about $15 \mathrm{~m}$ from the lysimeter (see Fig. 1).

The location of both lysimeter and Bowen station must meet the 'fetch' requirements to allow the formation of a logarithmic profile of the wind speed. These requirements are: (i) the cultivated surface is sufficiently extensive, mainly in the dominant wind direction; (ii) during the study period neutral stability conditions are presented, what allows vertical turbulent transport coefficients to be similar in the case of transporting water vapor and sensible heat; and (iii) the utilized instruments are sensitive enough for detecting 
G Model
AGWAT-4001; No. of Pages 12

D. Escarabajal-Henarejos et al. / Agricultural Water Management xxx (2014) $x x x-x x x$

Bowen station

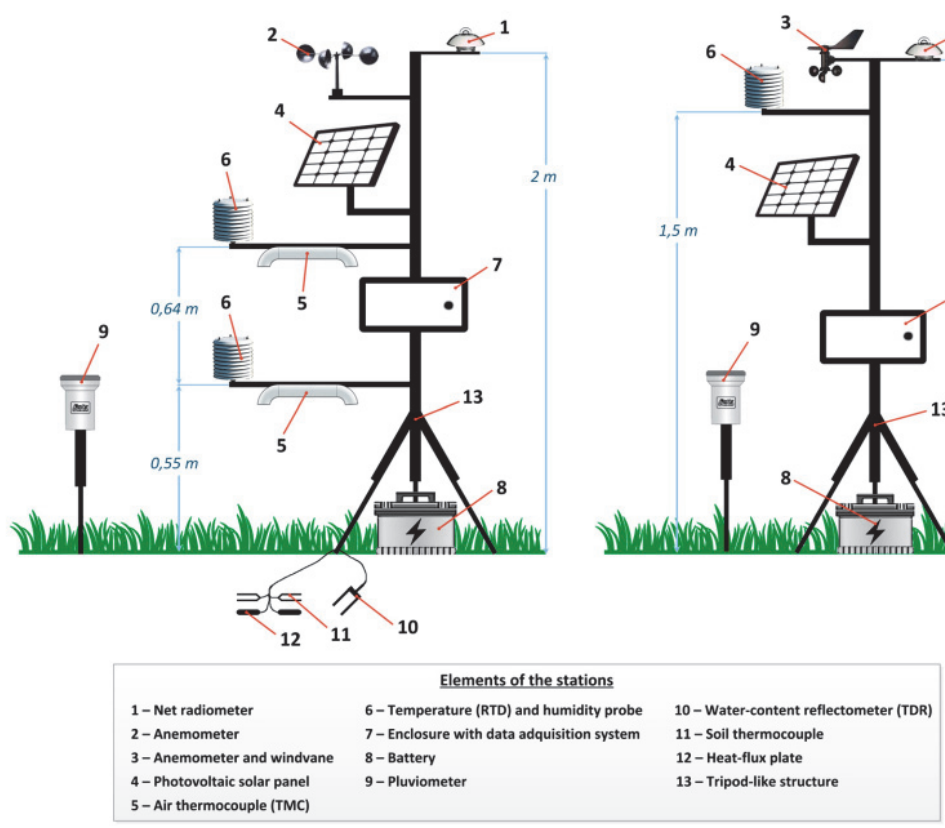

Agroclimatic station

1 1<smiles>C1CC2CCC1C2</smiles>

Fig. 3. Design and components of both the Bowen and the agroclimatic stations used in the experiment.

differences in temperature, humidity and wind speed at two heights. The location used for both the lysimeter and the Bowen station into the experimental plot (see. Fig. 1) permitted to maintain a fetch higher than $49.5 \mathrm{~m}$ regardless of the direction of the prevailing winds. This fetch was enough to perform the measurements because, regardless of the wind direction, it was 20 times higher than the height at which the measurement equipment was placed (Heilman et al., 1989).

With regard to net irradiance $\left(R_{n}\right)$, it was measured using a net radiometer (NR-LITE, Campbell Scientific Spain Inc., CSI. Logan, UT, USA), placed at $2 \mathrm{~m}$ above ground level. The soil heat flux values $(G)$ were taken from a representative soil, and then were calculated using the combined method (Payero et al., 2003). This method corrects the thermal flows measured with the aid of buried heat flux plates by evaluating the soil thermal capacity and by measuring temperature changes over time and the effect of soil moisture content. To this end, two HFP01 soil heat flow plates (Hukseflux, Holland) were buried to a depth of $8 \mathrm{~cm}$ and separated $1 \mathrm{~m}$, and four thermocouples $(2+2)$ made of chromium-constantan (TCAV, Type E) were installed vertically over the thermal plates at a depth of $2-6 \mathrm{~cm}$ with a CS616 water content reflectometer (Campbell Scientific Spain Inc., CSI. Logan, UT, USA) (Fig. 3).

In addition to the calculation of the available energy $\left(R_{n}-G\right)$, the BREB method also requires to determine the temperature and humidity gradients above the reference surface. Both gradients were measured with sensors installed on two metal arms at different heights: $0.55 \mathrm{~m}$ and $1.19 \mathrm{~m}$. The temperature gradient was assessed by using two E-type fine-wire thermocouples (chromeconstantan) with a diameter of $76 \mu \mathrm{m}$, which were aspirated using a circulation fan system and protected from direct solar radiation. In turn, the humidity gradient was checked using a mirror dew-point hygrometer (ALMEMO, Ahlborn Mess. Und R. Germany), which was fed alternatively by two independent pumps, one in each arm. With the objective of obtaining comparative measurements, both gradients were also evaluated by using two CS215 sensors (Campbell Scientific Spain Inc., CSI. Logan, UT, USA), which were also installed on each arm of the BREB system. These CS215 sensors are equipped with a thermometric probe to measure air temperature, which integrates a platinum resistance of $1000 \Omega$ and a capacitive relative humidity probe, which is based on changes of electrical capacitance of the air.

The station (see Fig. 3) was also equipped with a RAIN-O-MATIC pluviometer (Campbell Sci. Inst., USA) and an A100 cup anemometer (Campbell Scientific Spain Inc., CSI. Logan, UT, USA), which permitted to correct the $R_{n}$ values according to wind speed by following the recommendations of the radiometer manufacturer.

The BREB system was programed to read each climate variable with a frequency of $1 \mathrm{~Hz}$. Air intakes of the hygrometer were alternated every $2 \mathrm{~min}$, giving a delay of 40 s to stabilize measurements. Data for all variables were registered every second, storing the mean values every 5, 20 and $60 \mathrm{~min}$ in a CR1000 datalogger (Campbell Scientific Spain Inc., CSI. Logan, UT, USA).

The measurements of the differences in temperature ( $\left.\Delta T=T_{1}-T_{2}\right)$ and vapor pressure $\left(\Delta e=e_{1}-e_{2}\right)$ obtained between heights $z_{1}=0.55 \mathrm{~m}$ and $z_{2}=1.19 \mathrm{~m}$, were used to calculate the Bowen-ratio coefficient $(\beta)$ according to the following equation:

$\beta=\frac{H}{\lambda E}=\gamma \frac{\Delta T}{\Delta e}$

where $\beta$ is the Bowen-ratio, $H$ is the sensible heat flux $\left(\mathrm{Wm}^{-2}\right)$, $\lambda E$ is the latent heat flux $\left(\mathrm{W} \mathrm{m}^{-2}\right), \gamma$ is the psychrometric constant $\left(\mathrm{kPa}{ }^{\circ} \mathrm{C}^{-1}\right), \Delta T$ is the air temperature gradient $\left({ }^{\circ} \mathrm{C}\right)$ between two heights above the surface, and $\Delta e$ is the gradient of vapor pressure $(\mathrm{kPa})$ at the same two heights than $\Delta T$. The Bowen-ratio coefficient 
G Model
AGWAT-4001; No. of Pages 12
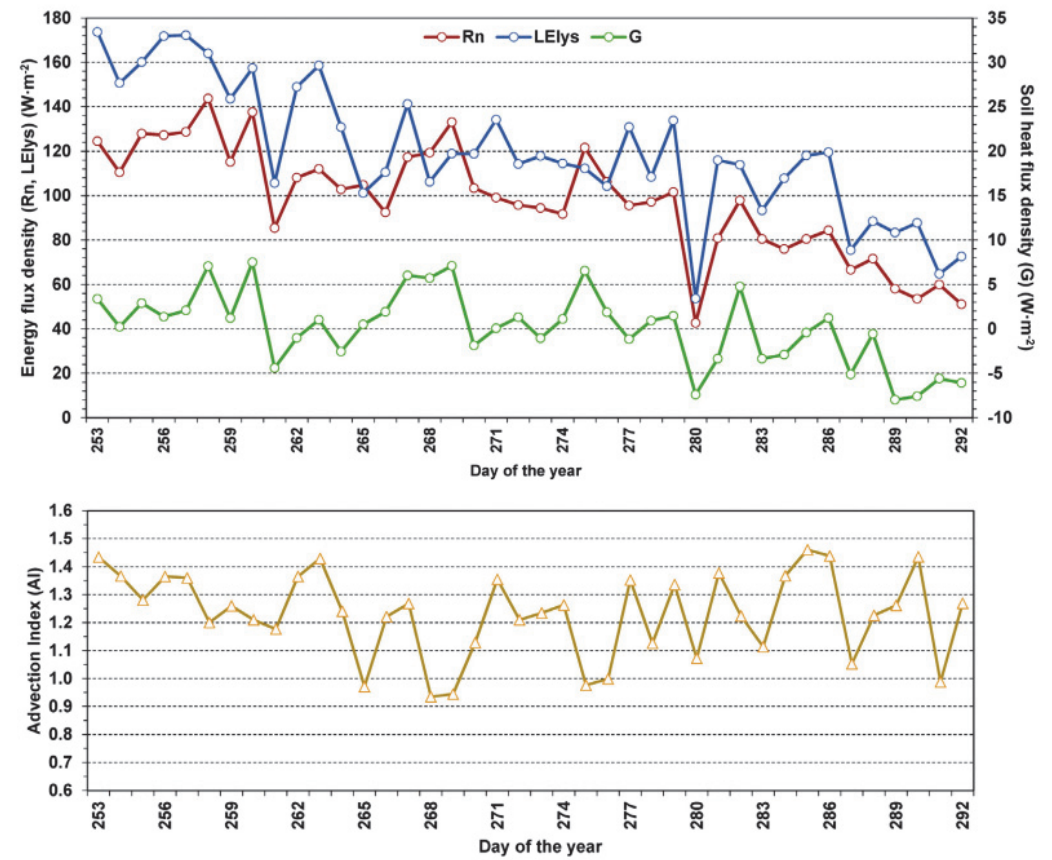

Fig. 4. Energy balance components and advection index during the experiment: net irradiance $\left(R_{n}\right)$, soil heat flux $(G)$, lysimeter evapotranspiration ( $\left.\mathrm{LE}_{\mathrm{lys}}\right)$, and advection index $(\mathrm{AI})\left[\mathrm{AI}=\mathrm{LE}_{\mathrm{lys}} /\left(R_{n}-G\right)\right]$.

$(\beta)$ was then used in Eq. (4) to obtain the mean values of the latent heat flux $(\lambda E)$, that is, evapotranspiration, for each hourly period:

$\lambda E=\frac{\left(R_{n}-G\right)}{1+\beta}$

In Eq. (4), $\lambda E$ represents the ET expressed in terms of energy $\left(\mathrm{W} \mathrm{m}^{-2}\right), R_{n}$ is the net irradiance $\left(\mathrm{W} \mathrm{m}^{-2}\right), G$ indicates the soil heat flux density into the ground $\left(\mathrm{W} \mathrm{m}^{-2}\right)$ and $\beta$ represents the Bowenratio.

A limitation of the BREB method that must be mentioned is its instability and loss of accuracy when $H$ and $\lambda E$ fluxes are approximately equal but with opposite sign. In this case $\beta$ tends to -1 $(\beta=\lambda E / H)$, and Eq. (4) tends to infinity, what requires to discard the periods in which this happens. This fact generally occurs at day times when $\lambda E$ and $H$ fluxes are usually small and opposite (at sunrise, at sunset and overnight). To overcome the problem and discard the periods in which this happens, the $\beta$ values included in a fixed range $(\beta<-0.75$ or $-1.3<\beta<-0.7)$ can be excluded, regardless of the mistakes committed during the measurement of the variables that define it (Ortega-Farias et al., 1996; Unland et al., 1996). Nevertheless, this study has followed the indications by Perez et al. (1999), who define a variable exclusion range of $\beta$ depending on the measurement accuracy.

\subsection{Advective conditions during the test}

A phenomenon observed in arid agricultural areas, mainly in crops and surfaces with low-growing plants, is local advection on evapotranspiration rate (Priestley and Taylor, 1972; Leite et al., 1990; Jiyane and Zermeño-González, 2003). This phenomenon is the result of a displacement of heat and dry air masses from the surroundings (dry and hot surfaces) into the plot, what affects to ET flux (Tolk et al., 2006). Lee et al. (2004) demonstrated that ET flux on well-irrigated crops may exceed net radiation due to an energy excess supplied by a sensible heat advection from adjacent dry fields. This means that when a determined location is affected by local advection on ET rate, latent heat flux must be multiplied by an advection factor which permits to obtain real evapotranspiration (Priestley and Taylor, 1972; Pérez and Castellví, 2002; Jiyane and Zermeño-González, 2003). Figuerola and Berliner (2005) provide in their study a more detailed description of the evapotranspiration process under advective conditions, and Gavilan and Berengena (2007) analyze the influence of this phenomenon in the accuracy of the BREB method to measure evapotranspiration in advective semi-arid climates.

Although this differs from the main objective of the study, the analysis of this phenomenon is required to understand the differences of $\lambda E$ fluxes that the FAO-56 methodology and the BREB method provide with respect to the lysimeter. The advection intensity was quantified by using an evaporation fraction coefficient or 'Advection Index' (AI), which is calculated as the ratio between $\lambda E$ and $\left(R_{n}-G\right)$ (Todd et al., 2000), being $\lambda E$ the latent-heat flux measured by the lysimeter and expressed in terms of energy $\left(\mathrm{W} \mathrm{m}^{-2}\right)$ $R_{n}$ the net radiation $\left(\mathrm{W} \mathrm{m}^{-2}\right.$ ) and $G$ the soil heat flux density into the ground $\left(\mathrm{W} \mathrm{m}^{-2}\right)$. The presence of advection is evidenced by an advection index greater than unity (Priestley and Taylor, 1972), and the higher its value is, the greater the contribution of sensible heat that increases ET flux is.

\section{Results and discussion}

\subsection{Quantification of sensible-heat advection}

The energy balance components at the surface are shown in Fig. 4. In order to detect the presence of local advection, the average daily 'Advection Index' (AI) has been included. The analysis of 
G Model AGWAT-4001; No. of Pages 12 ARTICLE IN PRESS

D. Escarabajal-Henarejos et al. / Agricultural Water Management $x x x$ (2014) $x x x-x x x$
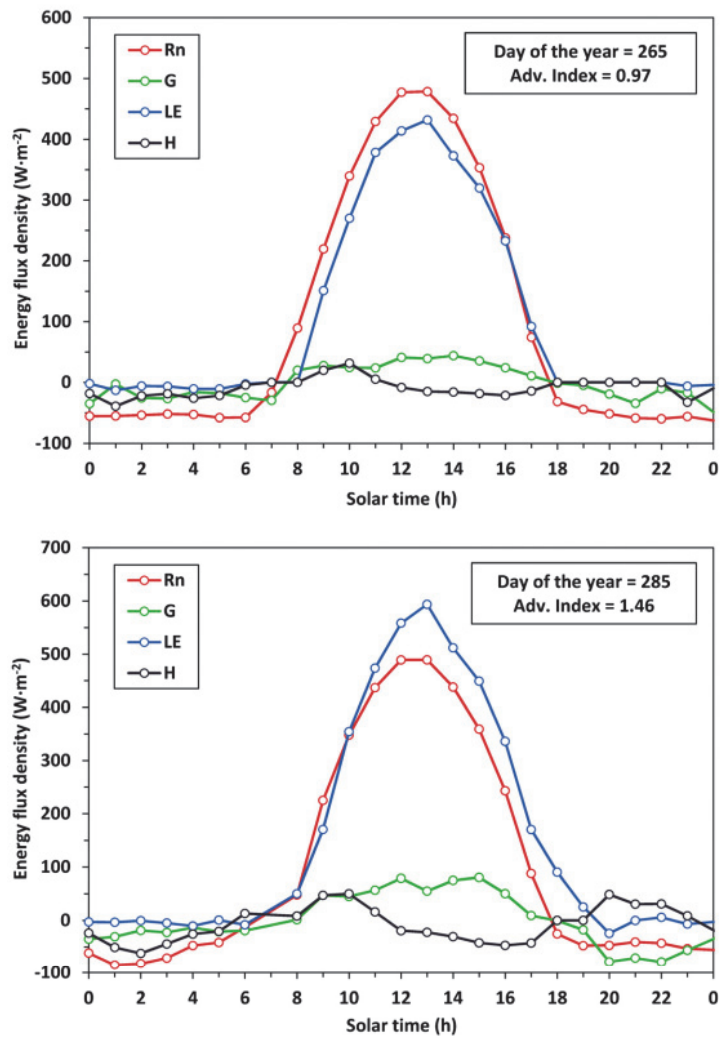

Fig. 5. Energy balance components during 2 days of the experiment: net irradiance $\left(R_{\mathrm{n}}\right)$, soil heat flux $(G)$, latent heat flux (LE), and sensible heat flux $(H)$.

the energy balance showed a process of sensible-heat advection, which occurred almost daily. 34 days from the total of 40 days of the study ( $85 \%$ of the study period) were found to be advective, obtaining AI values higher than 1.20 during 27 days. This phenomenon was rather severe on days 253,263, 285, 286 and 290, with indices reaching values greater than 1.40 (Fig. 5). This means that about $40 \%$ of the energy used to evaporate water was supplied by advective heat. Due to the lysimeter is placed at the center of the parcel the fetch was around $49.5 \mathrm{~m}$ regardless the wind direction. Thence, it is reasonable to assume that the predominant advective process is of regional nature.

\subsection{Definition of rejected periods}

According to the procedure described by Perez et al. (1999), Fig. 6 shows the rejection frequency for hourly periods during the 40 days of the study, and for each one of the devices used for calculating the temperature gradients required by the BREB method (TMCs and RTDs). In both cases, the frequency of rejected hours is practically zero during the middle of the day (in which most of the evapotranspiration takes place).

As can be seen in Fig. 6, from 18:00 (solar time) coinciding with the sunset, the frequency of rejection increased until it reached a maximum of 0.58 for TMCs and 0.70 for RTDs at 20:00 (solar time), and then it oscillated through all the night. Accumulated computation of excluded hours represents the $21.7 \%$ in the case of TMCs and the $20.5 \%$ for RTDs, obtaining $9.8 \%$ and $9.3 \%$ for daylight hours and
$30.2 \%$ and $28.6 \%$ for nighttime, respectively. These values are very similar in both cases, and have a very similar distribution pattern.

In both cases, frequency of rejection starts at sunset (18:00-19:00), extending through the night until sunrise (7:00-8:00). These results demonstrate that the imprecision of the BREB method is independent of the temperature measurement instrument used in the determination of $\beta$, since in both cases the same phenomenon takes place.

3.3. Comparison of ET values between lysimeter and FAO-56 equation and BREB method

Due to measurements from the weighing lysimeter correspond exclusively to water losses or gains, this device was used as a reference to assess the values of ET estimated by the FAO-56 equation and obtained with the BREB system, using both TMCs and RTDs. The comparisons were performed for hourly periods, since the limitations imposed by the resolution of the lysimeter did not permit to use shorter intervals. Fig. 7 shows, by way of illustration, the evolution of the hourly ET values measured by the lysimeter (ET $\mathrm{ETS}_{\mathrm{YY}}$ ), estimated by the FAO-56 methodology $\left(\mathrm{ET}_{\mathrm{FAO}}\right)$, and obtained with the BREB method using TMCs $\left(\mathrm{ET}_{\mathrm{TMC}}\right)$ and RTDs $\left(\mathrm{ET}_{\mathrm{RTD}}\right)$. The days showed in the figure were selected as representative of the study period in function of the advection index. The rest of the analyzed days showed similar patterns.

In a first analysis (Fig. 8), the hourly ET values estimated by the FAO-56 methodology and the hourly ET values obtained by the BREB method using TMCs and RTDs were compared with the ET values measured by the lysimeter. The lineal regression analysis performed between the hourly ET values estimated by the FAO-56 methodology ( $\mathrm{ET}_{\mathrm{FAO}}$ ) and the ET values measured by the lysimeter $\left(\mathrm{ET}_{\mathrm{LYS}}\right)$ showed that the FAO-56 Penman-Monteith equation trends to underestimate the evapotranspiration about $13.1 \%$, as it is evidenced by the slope of the linear regression line equal to 0.869 (see Fig. 8a). Similar results were obtained for barley by LópezUrrea et al. (2006b), who found that the FAO-56 methodology underestimated about $14 \%$ the values of crop evapotranspiration measured by the lysimeter. This underestimation was higher for values greater than $0.300 \mathrm{~mm} \mathrm{~h}^{-1}$ (see Fig. 8a). The squared correlation coefficient obtained was not significantly different to unity $(0.960)$, and the ordinate at the origin was not distant from zero (0.013). The root mean square error (RMSE) was $0.043 \mathrm{~mm} \mathrm{~h}^{-1}$, which resulted to be higher than the resolution of the lysimeter $\left(0.040 \mathrm{~mm} \mathrm{~h}^{-1}\right)$.

It has been demonstrated that the similarity between the ET values obtained by the lysimeter and the ET values calculated with the FAO-56 Penman-Monteith equation (Allen et al., 1998) decreases as wind speed increases (Lecina and Martínez-Cob, 2000). Under high evaporative demand conditions (mostly sunny days during summer), the ET rates are expected to further increase under windy conditions. In these situations, the Penman-Monteith equation with a fixed value of plant cover resistance $\left(r_{c}=70 \mathrm{~s} \mathrm{~m}^{-1}\right)$ seemed unable to adequately represent the water vapor flux from crops to the atmosphere and led to underestimate ET (Rana et al., 1994; Steduto et al., 1996; Pereira et al., 1999; Todorovic, 1999; Ventura et al., 1999; Lecina et al., 2003).

A linear regression analysis between hourly ET values measured by lysimeter ( $\mathrm{ET}_{\mathrm{LYS}}$ ) and ET values obtained by BREB method ( $\mathrm{ET}_{\mathrm{TMC}}$ and $\mathrm{ET}_{\mathrm{RTD}}$ ) was also performed (see Figs. 8 b and $\mathrm{c}$ ), discarding those values in which the Bowen-ratio $(\beta)$ entered in the exclusion range. The results indicated a similar evolution of the values calculated by both systems (TMCs and RTDs). The analysis showed that ET $\mathrm{LYS}_{\mathrm{S}}$ was clearly underestimated by the Bowen-ratio system during all analyzed days, especially in those days in which the advection phenomenon was more severe and during the early afternoon (similar 
G Model AGWAT-4001; No. of Pages 12

\section{ARTICLE IN PRESS}

D. Escarabajal-Henarejos et al. / Agricultural Water Management $x x x$ (2014) $x x x-x x x$
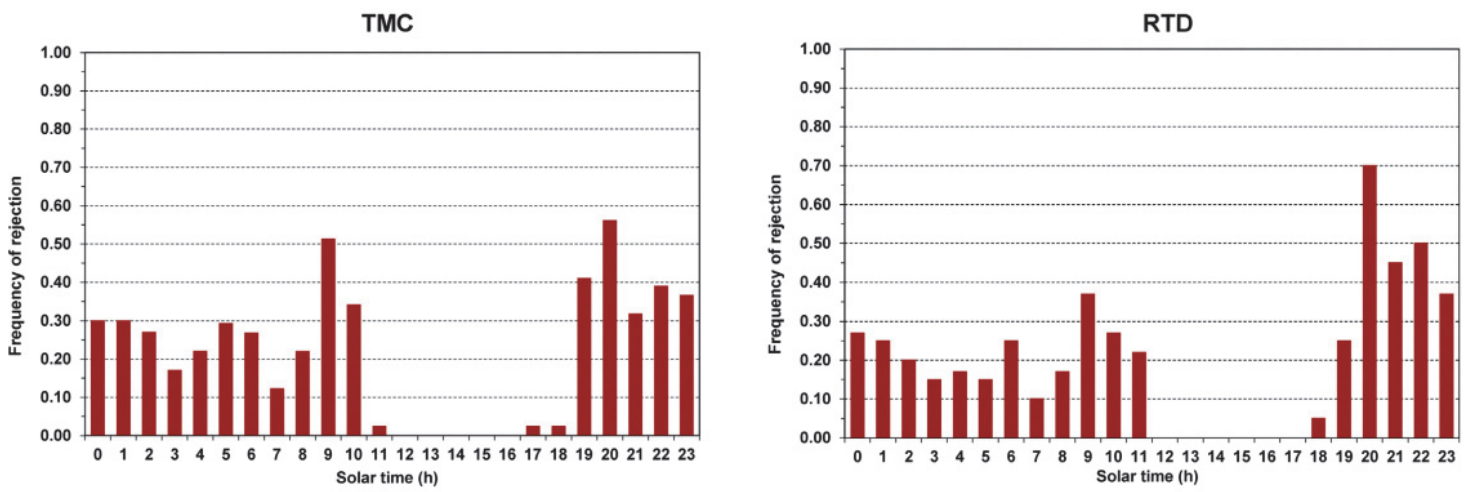

Fig. 6. Rejection frequencies for different hours of the day and for both devices used in the BREB method.
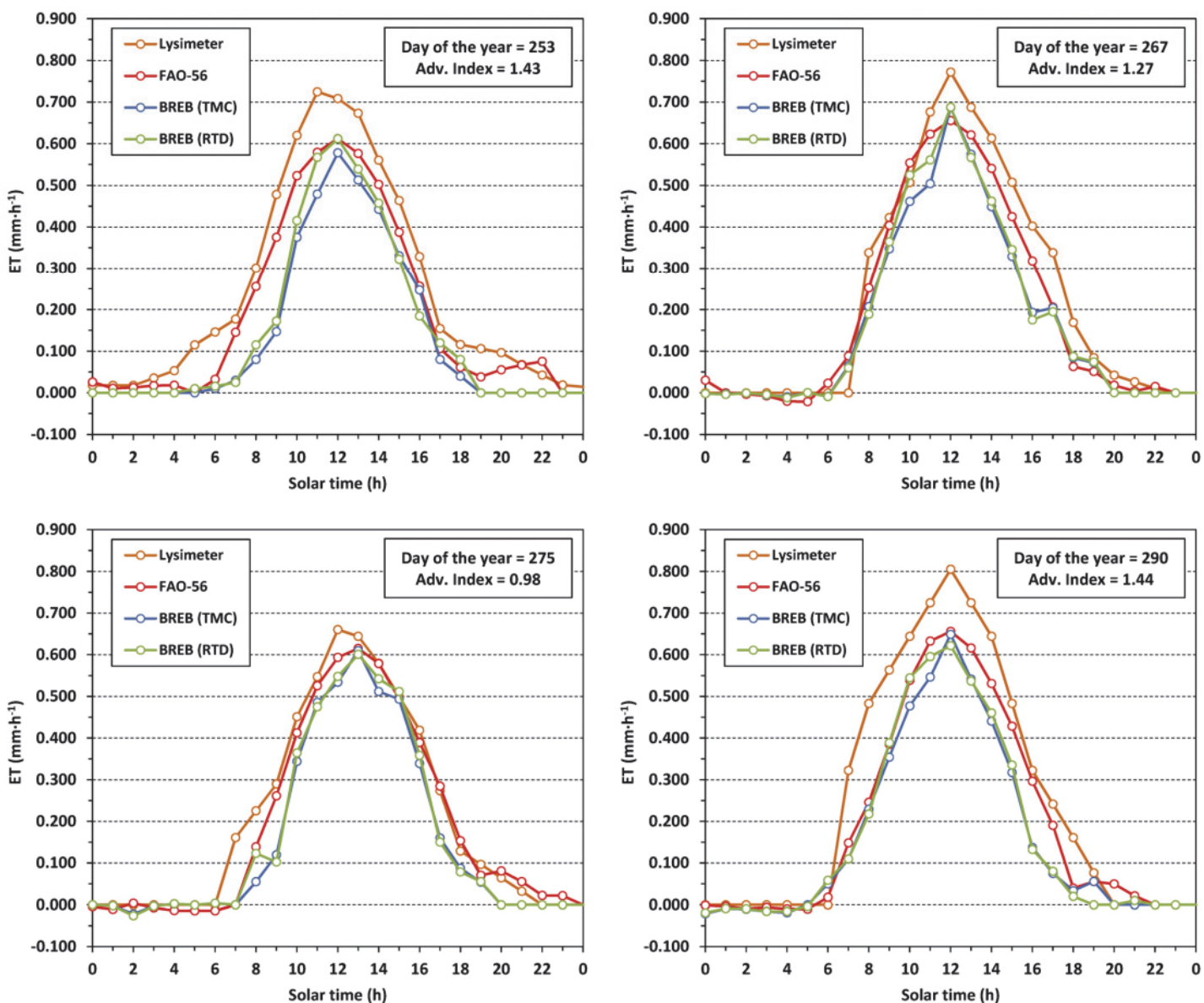

Fig. 7. Evolution of the hourly ET values during 4 representative days of the experiment, measured by the lysimeter, estimated by the FAO-56 methodology, and calculated with the BREB method using TMCs and RTDs.

Please cite this article in press as: Escarabajal-Henarejos, D., et al., Selection of device to determine temperature gradients for estimating evapotranspiration using energy balance method. Agric. Water Manage. (2014), http://dx.doi.org/10.1016/j.agwat.2014.09.011 

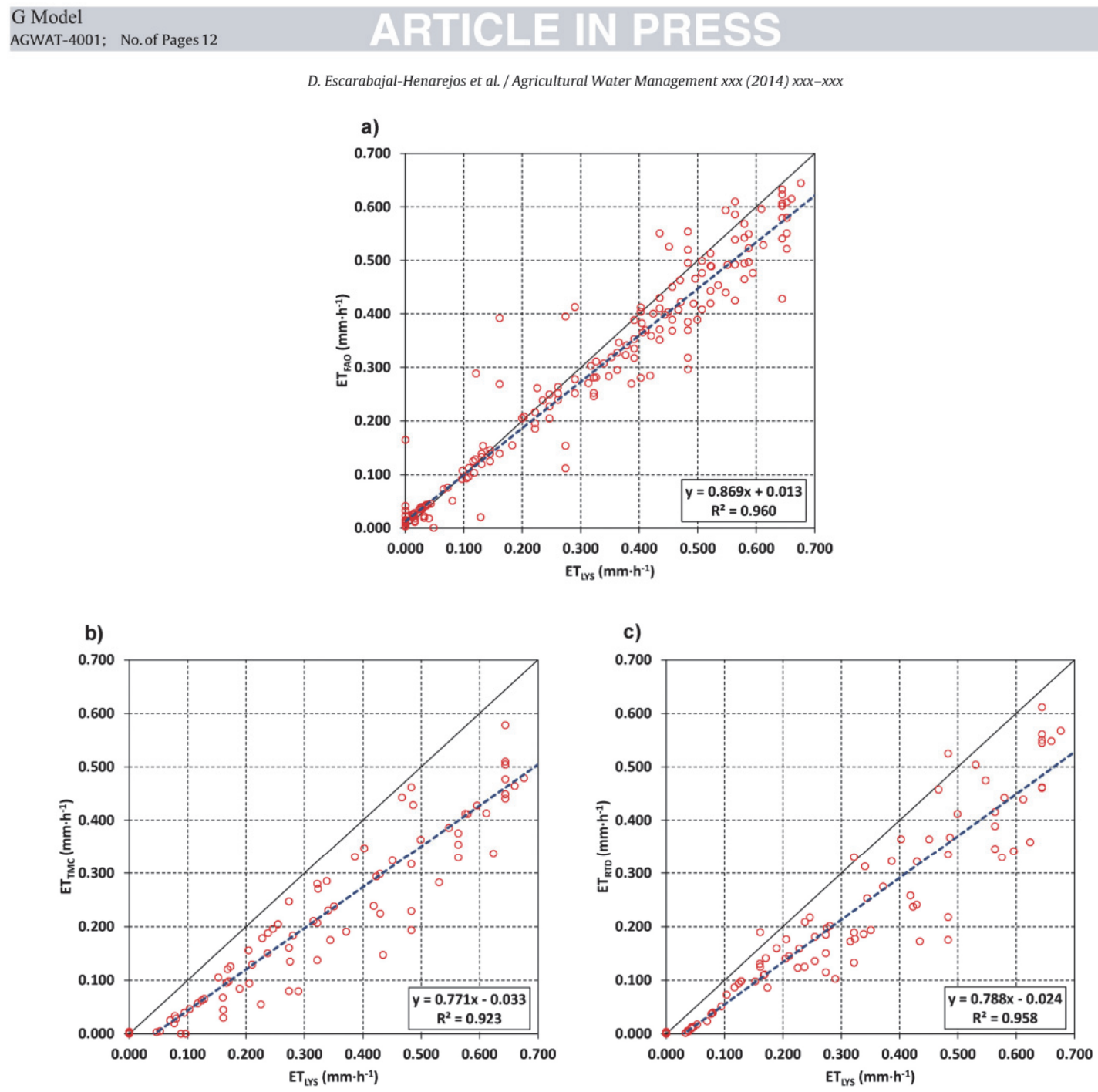

Fig. 8. Linear regression analysis between the hourly ET values measured by the lysimeter (ET $\mathrm{ET}_{\mathrm{LYS}}$ ) and (a) the hourly ET values estimated applying the FAO-56 Penman-Monteith equation (ET $\mathrm{E}_{\mathrm{FAO}}$ ), (b) the hourly ET values obtained with the Bowen-ratio system using TMCs (ET $\mathrm{TMC}_{\mathrm{TMC}}$, and (c) the hourly ET values obtained with the Bowen-ratio system using RTDs $\left(\mathrm{ET}_{\mathrm{RTD}}\right) \cdot R^{2}$ represents the squared correlation coefficient.

patterns were observed in the remaining days). These results agree with those obtained by Dunin et al. (1991) and Prueger et al. (1997), who found that the BREB method tends to underestimate lysimetric ET measurements under advective conditions.

Hourly ET values obtained by Bowen-ratio system using TMCs (ET $\mathrm{EMC}_{\mathrm{TMC}}$ ) also underestimated about $22.9 \%$ the ET values measured by the lysimeter, as evidenced by the slope of the linear regression line equal to 0.771 (see Fig. 8b). This underestimation was slightly minor for RTDs (21.2\%), obtaining a slope of the linear regression line equal to 0.788 (see Fig. 8c). The squared correlation coefficients obtained were 0.923 for TMCs and 0.958 for RTDs. In both cases, the ordinate at the origin $(-0.033$ for TMCs and -0.024 for RTDs) was not significantly different from zero. The obtained root mean square error (RMSE) was $0.042 \mathrm{~mm} \mathrm{~h}^{-1}$ for TMCs and $0.045 \mathrm{~mm} \mathrm{~h}^{-1}$ for RTDs. The evaluation results are shown in Table 1 . Therefore, the use of RTDs showed better results than TMCs when estimating ET with a Bowen-ratio system, attributable to the higher accuracy and stability of RTDs (almost ten times higher).

Table 1

Results of the linear regression analysis between the hourly ET values measured by lysimeter ( $\mathrm{ET}_{\mathrm{LYS}}$ ) and hourly ET values estimated by FAO-56 methodology (ET $\mathrm{EAO}$ ), and between ET $\mathrm{T}_{\mathrm{LYS}}$ and hourly ET values obtained by BREB method using TMCS (ET TMC) and RTDs (ET $\mathrm{ET}_{\text {RTD }}$ ).

\begin{tabular}{|c|c|c|c|c|c|c|c|}
\hline Figure number & $X$-axis & $Y$-axis & Sample size & Slope & Interception & $R^{2}$ & $\operatorname{RMSE}\left(\mathrm{mm} \mathrm{h}^{-1}\right)$ \\
\hline $8 a$ & $\mathrm{ET}_{\text {LYS }}$ & $\mathrm{ET}_{\mathrm{FAO}}$ & 816 & 0.869 & 0.013 & 0.960 & 0.043 \\
\hline $8 \mathrm{~b}$ & $\mathrm{ET}_{\text {LYS }}$ & $\mathrm{ET}_{\mathrm{TMC}}$ & 704 & 0.771 & -0.033 & 0.923 & 0.042 \\
\hline $8 \mathrm{c}$ & $\mathrm{ET}_{\text {LYS }}$ & $\mathrm{ET}_{\mathrm{RTD}}$ & 723 & 0.788 & -0.024 & 0.958 & 0.045 \\
\hline
\end{tabular}


G Model AGWAT-4001; No. of Pages 12

10 ARTICLE IN PRESS

a)

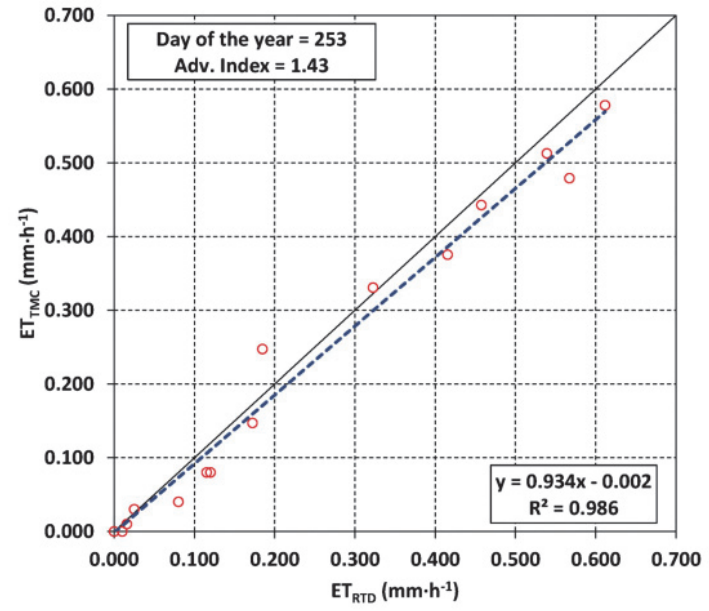

c)

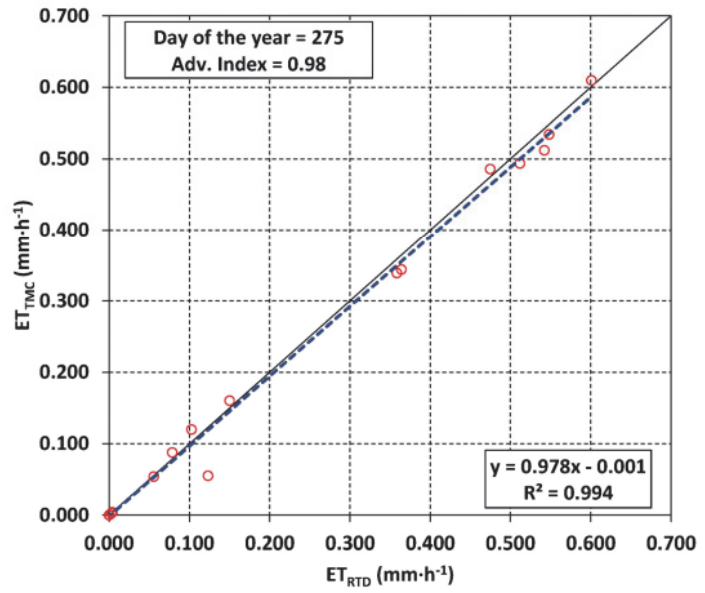

b)

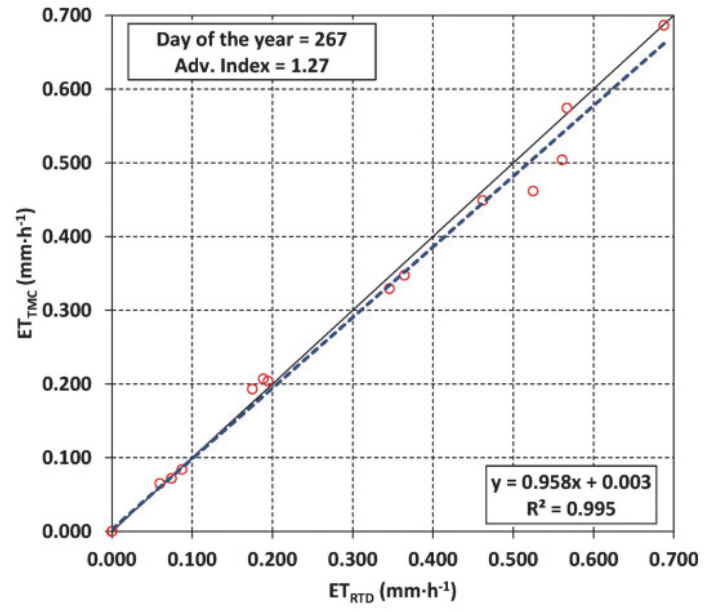

d)

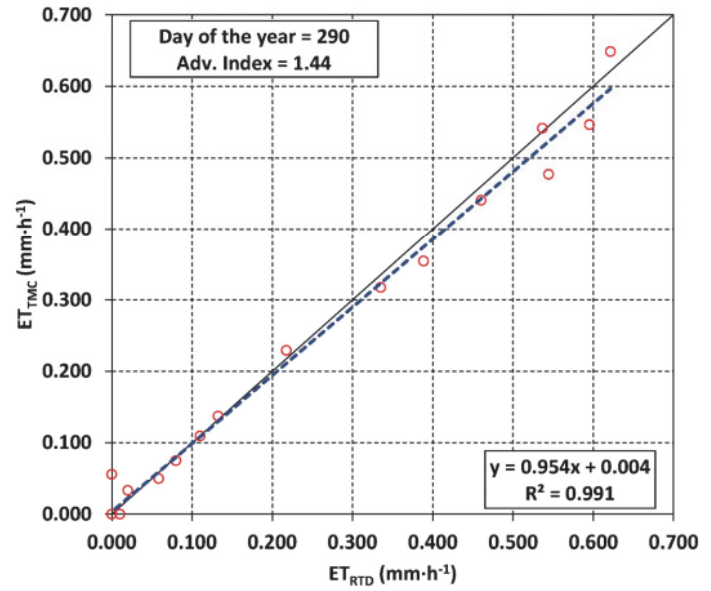

Fig. 9. Linear regression analysis for 4 representative days of the experiment between the hourly ET values estimated with the BREB method using TMCs (ET TMC) and RTDs $\left(\mathrm{ET}_{\mathrm{RTD}}\right) \cdot R^{2}$ represents the squared correlation coefficient.

\subsection{Comparison of ET values between TMC and RTD}

The ET values obtained by the Bowen-ratio system using TMCs (ET $\mathrm{TMC}_{\mathrm{TC}}$ ) and RTDs (ET $\mathrm{RTD}_{\mathrm{D}}$ ) were compared in order to demonstrate the possibility of replacing the TMCs installed in the current Bowen stations with RTDs. Fig. 9 shows a lineal regression analysis between the hourly ET values obtained by the BREB method using TMCs and RTDs for some representative sample days (see Table 2). The performed analysis shows the great similarity between the estimated ET values, regardless of the temperature probe used in the Bowen-ratio system. In all cases, the correlation coefficients were higher than 0.985 and the RMSE values were in the range $0.016-0.023 \mathrm{~mm} \mathrm{~h}^{-1}$. Nevertheless, $\mathrm{ET}_{\mathrm{TMC}}$ underestimated slightly $\mathrm{ET}_{\mathrm{RTD}}$ in all analyzed days, as evidenced by the slope of the linear regression line different to unity (see Fig. 9). $\mathrm{ET}_{\mathrm{TMC}}$ underestimated an average of $4.4 \%$ the $\mathrm{ET}_{\mathrm{RTD}}$ values, as it further underestimated the ET lysimetric values (see Figs. 8b and $\mathrm{c}$ ).

Table 2

Results of the linear regression analysis between the hourly ET values calculated with the BREB method using TMCs (ET $\mathrm{ETMC}_{\mathrm{TMC}}$ ) and RTDs (ET $\mathrm{ETD}_{\mathrm{RT}}$ ).

\begin{tabular}{|c|c|c|c|c|c|c|c|}
\hline Figure number & $X$-axis & $Y$-axis & Sample size & Slope & Interception & $R^{2}$ & $\operatorname{RMSE}\left(\mathrm{mm} \mathrm{h}^{-1}\right)$ \\
\hline 9a & $\mathrm{ET}_{\text {RTD }}$ & $\mathrm{ET}_{\text {TMC }}$ & 14 & 0.934 & -0.002 & 0.986 & 0.023 \\
\hline $9 \mathrm{~b}$ & $\mathrm{ET}_{\text {RTD }}$ & $\mathrm{ET}_{\text {TMC }}$ & 17 & 0.958 & 0.003 & 0.995 & 0.016 \\
\hline $9 c$ & $\mathrm{ET}_{\text {RTD }}$ & $\mathrm{ET}_{\text {TMC }}$ & 16 & 0.978 & -0.001 & 0.994 & 0.017 \\
\hline $9 d$ & $\mathrm{ET}_{\text {RTD }}$ & $\mathrm{ET}_{\text {TMC }}$ & 15 & 0.954 & 0.004 & 0.991 & 0.021 \\
\hline
\end{tabular}




G Model
AGWAT-4001; No. of Pages 12

Thus, the Bowen-ratio system using RTDs provided the best fit to the ET values measured by the lysimeter (see Fig. 8c), what justifies the great suitability of using RTDs in the Bowen-ratio systems to estimate evapotranspiration. However, the main limitation of the obtained results is the short time period registered (only 40 days at the end of summer when ET is relatively low), so it is recommended to extend the comparative period in order to ensure quality of results, including periods of high evaporative demand of the atmosphere.

\section{Conclusions}

The study developed in this paper allowed to determine the evapotranspiration of a reference crop using three different methodologies: lysimetry, FAO-56 Penman-Monteith equation and BREB method. Furthermore, BREB method was applied using a Bowen-ratio system equipped with different sensors for measuring temperature gradients (TMCs and RTDs). Based on the analysis and comparisons performed in this study, the ET values measured by the lysimeter were underestimated around $13.1 \%$ by Penman-Monteith equation; this behavior can be attributed to the error introduced by assuming a fixed value of plant cover resistance $\left(r_{c}=70 \mathrm{~s} \mathrm{~m}^{-1}\right)$ through all day. However, FAO-56 methodology was the best fit to the ET values provided by the lysimeter, obtaining a squared correlation coefficient of 0.960 .

The BREB method also underestimated the ET values of the lysimeter, due to the detected advection phenomenon that nullifies the hypothesis of similarity between turbulent transport coefficients. Although the comparison between the BREB method using TMCs and RTDs yielded no significant differences between the two devices, as evidenced by the squared correlation coefficients higher than 0.985 , TMCs provided a slightly underestimation of the ET values measured by the BREB method using RTDs (4.4\%). Bowen-ratio system using TMCs underestimated about $22.9 \%$ the ET values measured by the lysimeter, and the same system using RTDs, a $21.2 \%$. In this case, RTDs denoted a greater similarity to lysimetric ET values, obtaining a squared correlation coefficient of 0.958 in comparison with TMCs (0.923). No loss of accuracy as result of self-heating in RTDs was observed.

The results presented in this paper suggest that is possible to replace the TMCs installed in the current Bowen stations with RTDs. In addition to the above, the use of RTDs presents several functiona advantages when compared with TMCs. For example, RTDs have a simpler installation and lower long-term maintenance costs. By contrast, TMCs require a more frequent maintenance and inspections to verify proper operation of the fans (they must circulate a continuous air flow through the tubes where TMCs are usually installed) and cleanliness of the filters installed in the tubes. Also, RTDs are more robust and durable devices, while the extreme thinness and fragility of TMCs makes them susceptible to breakage, and a protection from external agents is also required.

\section{Acknowledgments}

The development of this work was supported by the Seneca Foundation (Murcia Regional Authority, Spain) through the project with ref $08729 / \mathrm{PI} / 08$ and the Foundation for the sustainable development of Castilla-La Mancha (FUNDESCAM) through the collaboration agreement with the Technical University of Cartagena for the Assessment of the Bowen Ratio - Energy Balance Method to measure evapotranspiration by using a weighing lysimeter.

\section{References}

Aboukhaled, A., Alfaro, A., Smith, M., 1982. Lysimeters. In: FAO Irrigation an Drainage Paper No. 39. FAO, Rome, Italy (p. 68).
Ahmadi, S.H., Fooladmand, H.R., 2008. Spatially distributed monthly reference evapotranspiration derived from the calibration of Thornthwaite equation: a case study, South of Iran. Irrig. Sci. 26 (4), 303-312.

Andreas, E.L., Jordan, R.E., Mahrt, L., Vickers, D., 2013. Estimating the Bowen ratio over the open and ice-covered ocean. J. Geophys. Res.-Oceans 118, 4334-4345. Al-Ghobari, H.M., 2000. Estimation of reference evapotranspiration for southern region of Saudi Arabia. Irrigation Sci. $19(2), 81-86$.

Allen, R.G., Jensen, M.E., Wright, J.L., Burman, R.D., 1989. Operational estimates of reference evapotranspiration. Agron. J. 81, 650-662.
ref.,

Allen, R.G., Pereira, L.S., Raes, D., Smith, M., 1998. Crop evapotranspiration: guidelines for computing crop water requirements. In: FAO Irrigation and Drainage Papers. FAO, Rome, Italy, p. 328 .

Allen, R.G., Wright, J.L., Pruitt, W.O., Pereira, L.S., 2007. Water requirements. In: Hoffman, G.J., Evans, R.G., Jensen, M.E., Martin, D.L., Elliot, R.L. (Eds.), Design and Operation of Farm Irrigation Systems, ASABE, Monograph. ASABE, St. Joseph, MI, pp. 208-288

Allen, R.G., Pereira, L.S., Howell, T.A., Jensen, M.E., 2011a. Review. Evapotranspiration information reporting: I: Factors governing measurement accuracy. Agric. Water Manage 98, 899-920.

Allen, R.G., Pereira, L.S., Howell, T.A.,Jensen, M.E., 2011b. Review. Evapotranspiration information reporting: II: Recommended documentation. Agric. Water Manage 98, 921-929.

Aydin, M., 2008. A model for evaporation and drainage investigations at ground of ordinary rainfed-areas. Ecol. Model. 217 (1-2), 148-156.

Baillie, I.C., 2001. Soil survey staff 1999, soil taxonomy. Soil Use Manage. 17 (1), $57-60$

Balbontin-Nesvara, C., Calera-Belmonte, A., Gonzalez-Piqueras, J., CamposRodriguez, I., Lopez-Gonzalez, M.L., Torres-Prieto, E., 2011. Vineyard evapotranspiration measurements in a semiarid environment: Eddy covariance and Bowen ratio comparison. Agrociencia 45 (1), 87-103,

Bezerra, B.G., da Silva, B.B., Bezerra, J.R.C., Sofiatti, V., dos Santos, C.A.C., 2012. Evapotranspiration and crop coefficient for sprinkler-irrigated cotton crop in Apodi Plateau semiarid lands of Brazil. Agric. Water Manage. 107, 86-93,

Bowen, I.S., 1926. The ratio of heat losses by conduction and by evaporation from any water surface. Phys. Rev. 27 (6), 779-787.

Campbell Scientific, 1998. Bowen Ratio Instrumentation, Instruction Manual. Campbell Scientific, Logan, UT, p. 23

Cancela, J.J., Cuesta, T.S., Neira, X.X., Pereira, L.S., 2006. Modelling for improved irrigation water management in a temperate region of Northern Spain. Biosyst. Eng. 94 (1), 151-163.

Cui, Y.J., Zornberg, J.G., 2008. Water balance and evapotranspiration monitoring in geotechnical and geoenvironmental engineering. Geotech. Geol. Eng. 26 (6), $783-798$

De Bruin, H.A.R., 2008. Theory and application of large aperture scintillometers. In: Short Course Notes. Scintec Corp.

DehghaniSanij, H., Yamamoto, T., Rasiah, V., 2004. Assessment of evapotranspiration estimation models for use in semi-arid environments. Agric. Water Manage. 64 (2), 91-106.

Dicken, U., Cohen, S., Tanny, J., 2013. Examination of the Bowen ratio energy balance technique for evapotranspiration estimates in screenhouses. Biosyst. Eng. 114 $397-40$

Doorenbos, J., Pruitt, W.O., 1977. Crop water requirements. In: FAO Irrigation and Drainage Paper No.24. FAO, Rome.

Dunin, F.X., Barrs, H.D., Meyer, W.S., Trevitt, A.C.F, 1991, Foliage temperature and latent heat flux of irrigated wheat. Agric. For. Meteorol. 55 (1-2), $133-147$

Elsawwaf, M., Willems, P., Pagano, A., Berlamont, J., 2010. Evaporation estimates from Nasser Lake, Egypt, based on three floating station data and Bowen ratio energy budget. Theor. Appl. Climatol. 100, 439-465.

Fandiño, M., Cancela, J.J., Rey, B.J., Martínez, E.M., Rosa, R.G., Pereira, L.S., 2012. Using the dual-Kc approach to model evapotranspiration of Albariño vineyards (Vitis vinifera L. cv. Albariño) with consideration of active ground cover. Agric. Water
vitis vimifera L. CV. Albariño) with

Fernández García, F., 1995. Manual de climatología aplicada: Clima, medio ambiente y planificación (in Spanish). Sintesis, Madrid.

Fernández-Pacheco, D.G., Escarabajal-Henarejos, D., Ruiz-Canales, A., Conesa, J., Molina-Martínez, J.M., 2014. A digital image-processing-based method for Molina-Martinez, J.M., colf. A digital Image-processing-based method for
determining the crop coefficient of lettuce crops in the southeast of Spain. Biosyst. Eng. 117, 23-34.

Figuerola, P.I., Berliner, P.R., 2005. Evapotranspiration under advective conditions. Int. J. Biometeorol. 49, 403-416.

Fritschen, L., Simpson, J., 1982. An automatic system for measuring Bowen ratio gradients using platinum resistance elements. In: Schooley, J.F. (Ed.), Temperature, Its Measurement and Control in Science and Industry, 5. Am. Institute of Physics, New York, NY, pp. 739-742.

Gavilan, P. Berengena, J.2007. Accuracy of the Bowen ratio-energy balance method for measuring latent heat flux in a semiarid advective environment. Irrig. Sci. 25 (2), 127-140.

Gocic, M.. Trajkovic, S., 2010. Software for estimating reference evapotranspiration using limited weather data. Comput. Electron. Agric. 71 (2), 158-162

Gocic, M., Trajkovic, S., 2011. Service-oriented approach for modeling and estimating reference evapotranspiration. Comput. Electron. Agric. 79 (2). $153-158$

Harrold, L.L., Watts, C.J., Rodriguez, J.-C., De Bruin, H.A.R.,1966. Measuring evapotranspiration by lysimetry. In: Proceeding Conference on Evapotranspiration. Am. Soc. Agr. Engrs, Chicago, IL, USA, pp. 28-33. 
G Model
AGWAT-4001; No. of Pages 12

Hartogensis, O.K., Watts, C.J., Rodriguez, J.-C., De Bruin, H.A.R., 2003. Derivation of an

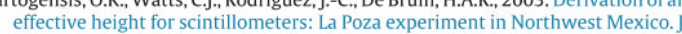
Hydrometeorol. 4 (5), 915-928.

Heilman, J.L., Brittin, C.L., Neale, C.M.U., 1989. Fetch requirements for Bowen-ratio measurements of latent and sensible heat fluxes. Agric. For. Meteorol. 44 (3-4) 261-273.

Howell, T.A., McCormick, R.L., Phene, C.J., 1985. Design and installation of large weighing lysimeters. Trans. ASAE 28 (1), 106-112.

Itier, B., 1996. Measurement and estimation of evapotranspiration. In: Pereira is Feddes, R.A. Gilley, J.R. Lesaffre, B. (Eds.), Sustainability of Irrigated Agriculture. Feddes, R.A., Gilley, J.R., Lesaffre, B. (Eds.)

ASCE, 1974. Consumptive use of water and irrigation water requirements. In: Jensen, M.E. (Ed.), Rep. Tech. Com. on Irrig. Water Requirements, Irrig. and Drain. Div, ASCE, p. 227

Jensen, M.E., Burman, R.D., Allen, R.G., 1990. Evapotranspiration and Irrigation Water Requirements, ASCE-Manuals and Reports on Engineering Practice, No. 70. ASCE, New York, NY.

Jiyane,J., Zermeño-González, A., 2003. Applying the equilibrium evapotranspiration approach to irrigated agriculture in arid zones. Agrociencia 37 (6), 553-563.

Kirkham, R.R., Rockhold, M.L., Gee, G.W., Fayer, M.J., Campbell, M.D., Fritschen, LJ 1991. Lysimeters. Data acquisition and analysis. In: Proc. of the International Symposium on Lysimeters for Evapotranspiration and Environmental Measurements, ASCE, Honolulu, HI, USA, pp. 362-370.

Lee, X., Yu, Q., Sun, X., Liu, J., Min, Q., Liu, Y., Zhang, X., 2004. Micrometeorological fluxes under the influence of regional and local advection: a revisit. Agric. For Meteorol. 122(1-2), 111-124.

Leite, M.L., Sediyama, G.C., Coelho, D.T., Vieira, H.A., 1990. Determinação da evapotranspiração de equilibrio numa superficie cultivada com Feijoão (Phaseolus vulgaris L.) em duas densidades de plantío (in Portuguese). Ceres 37, 99-110.

Lecina, S., Martínez-Cob, A., 2000. Evaluación lisimétrica de la evapotranspiración de referencia semihoraria calculada con el método FAO Penman-Monteith. In: XVIII Congreso Nacional de Riegos, Huelva, Spain, pp. 37-38.

Lecina, S., Martínez-Cob, A.., Pérez, P.J., Villalobos, F..., Baselga,j.J.. 2003. Fixed versus variable bulk canopy resistance for reference evapotranspiration estimation using the Penman-Monteith equation under semiarid conditions. Agric. Water Manage. 60 (3), 181-198

López-Urrea, R., Martín de Santa Olalla, F., Fabeiro, C., Moratalla, A., 2006a. Testing evapotranspiration equations using lysimeter observations in a semiaric climate. Agric. Water Manage. $85(1-2), 15-26$

López-Urrea, R., Montoro, A., López-Fuster, P., 2006b. Estudio de las necesidades hídricas de la cebada (Hordeum vulgare L.) cultivada en un clima semiárido. In: XXIV Congreso Nacional de Riegos, Lugo, Spain.

López-Urrea, R., Martín de Santa Olalla, F., Montoro, A., López-Fuster, P., 2009a. Single and dual crop coefficients and water requirements for onion (Allium cepa L.) under semiarid conditions. Agric. Water Manage. 96 (6), 1031-1036.

López-Urrea, R., Montoro, A., López-Fuster, P., Fereres, E., 2009b. Evapotranspiration and responses to irrigation of broccoli. Agric. Water Manage. 96 (7), 1155-1161

Maidment, D.R. (Ed.), 1992. Handbook of Hydrology. McGraw-Hill, Austin, Texas. Makkink, G.P., 1957. Testing the Penman formula by means of lysimeters. J. Inst.

Marek, T.H., Schmeider, A.D., Howell, T.A., Ebeling, L.L., 1988. Design and construc tion of large weighing monolithic lysimeters. Trans. ASAE 31 (2), 477-484.

Martin de Santa Olalla, F.j., de Juan, J.A., 1993. Chapter: La programación de riegos. In: Agronomía del Riego. Mundi-Prensa, Madrid, pp. 549-610.

Meyers, T.P., Baldocchi, D.P., 2005. Current micrometerological flux methodologies with applications in agriculture. In: Hatfield, J.L., Baker, J.M. (Eds.), Micrometeorology in Agricultural Systems. Agronomy Monograph No. 47 in the Agro Series. American Society of Agronomy. Crop Science Society of America, Soil Science Society of America, Madison, WI, USA, pp. 381-396.

Ortega-Farias, S.O., Cuenca, R.H., Ek, M., 1996. Daytime variation of sensible heat flux estimated by the bulk aerodynamic method over a grass canopy. Agric. For. flux estimated by the bulk ae
Meteorol. $81(1-2), 131-143$.

Payero, J.O., Neale, C.M.U., Wright, J.L., Allen, R.G., 2003. Guidelines for validating Bowen ratio data. Trans. ASAE 46 (4), 1051-1060.

Peake, C., Riveros-Iregui, D., Lenters, J., Zlotnik, V., Ong, J., 2013. Environmental and groundwater controls on evaporation rates of a shallow saline lake in the western Sandhills Nebraska, USA. In: AGU Fall Meeting Abstracts, Western Sandhills, NE, USA, p. 1469, 1.

Penman, H.L., 1948. Natural evaporation from open water, bare soil and grass. Proc. R. Soc. London., Ser. A 193 (1032), 120-145.

Pereira, L.S., Perrier, A., Allen, R.G., Alves, I., 1999. Evapotranspiration: concepts and future trends. J. Irrig. Drain. Eng. 125 (5), 235-245 (ASCE).
Pérez, P.J., Castellví, F., 2002. Análisis de la evapotranspiración a escala local y regional en Cataluña (in Spanish). Ingeniería del agua 9 (1), 59-72.

Perez, P.J., Castellvi, F., Ibañez, M., Rosell, J.I., 1999. Assessment of reliability of Bowen ratio method for partitioning fluxes. Agric. For. Meteorol. 97 (3) 141-150.

Potter, B., Lenters, J., Hinkel, K., Shulski, M., Healey, N., Irmak, A., Jones, S., Sheng, Y. 2011. The summertime energy balance of a thermokarst lake in northern Alaska: a three-year study of seasonal and interannual variability. AGU Fall Meeting Abstracts 1,08 .

Priestley, C.H.B., Taylor, R.J., 1972. On the assessment of surface heat flux and evaporation using large-scale parameters. Mon. Weather Rev. 100, 81-92.

Prueger, J.H., Hatfield, J.L., Aase, J.K., Pikul Jr., J.L., 1997, Bowen-ratio comparisons with lysimeter evapotranspiration. Agron. I. 89 (5), 730-736

Pruitt, W.O., Lourence, F.J., 1985. Experiences in lysimetry for ET and surface drag measurements. Advances in Evapotranspiration, 74. American Society of Agricultural Engineers, St. Joseph, MI, USA, pp. 51-69, 85.

Rana, G., Losavio, N., Mastrorilli, M., Scarascia, M.E.V., 1990. Crop evapotranspiration measured by two energy balance methods under mediterranean climate. Act Hortic. 278, 517-524.

Rana, G., Katerji, N., Mastrorilli, M., El Moujabber, M., 1994. Evapotranspiration and $61-71$

Rana, G., Katerji, N., 2000. Measurement and estimation of actual evapotranspiration in the field under mediterranean climate: a review. Eur. J. Agron. 13, 125-153. Rosenberg, N.J., Blad, B.L., Verma, S.B., 1983. Microclimate: The Biological Environment, second ed. John Wiley, New York, NY

Savage, M.J., 2010. Field evaluation of polymer capacitive humidity sensors fo Bowen ratio energy balance flux measurements. Sensors 10 (8), 7748-7771.

Savage, M.J., Everson, C.S., Metelerkamp, B.R., 2009. Bowen ratio evaporation measurement in a remote montane grassland: data integrity and fluxes. J. Hydrol. $376(1-2), 249-260$

Shaw, R., Snyder, R.L., Medawar, C.K., Phene, C.J., 2003. Evaporation and eddy correlation. In: Encyclopedia of Water Science. Marcel Dekker, Inc., New York, NY, pp. 235-237.

Steduto, P., Caliandro, A., Rubino, P., Ben Mechlia, N., Masmoudi, M., Martínez-Cob, A., Faci, J.M., Rana, G., Mastrorilli, M., El Mourid, M., Karrou, M., Kanber, R, Kirda, C., El-Quosy, D., El-Askari, K., Ait Ali, M., Zareb, D., Snyder, R.L., 1996. Penman-Monteith reference evapotranspiration estimates in the Mediterranean region. In: Camp, C.R., Sadler, E.J., Yoder, R.E. (Eds.), Proc. Int. Conf. O Evapotranspiration and Irrig. Scheduling. San Antonio, TX, USA, pp. 357-364.

Thornthwaite, C.W., 1948. An approach toward a rational classification of climate. Geogr. Rev. 38, 55-94.

Todd, R.W., Evett, S.R., Howell, T.A., 2000. The Bowen ratio-energy balance method for estimating latent heat flux of irrigated alfalfa evaluated in a semi-arid, advec tive environment. Agric. For. Meteorol. 103, 335-348.

Todorovic, M., 1999. Single-layer evapotranspiration model with variable canopy resistance. J. Irrig. Drain. Eng. 125 (5), 235-24

Tolk, J.A., Evett, S.R., Howell, T.A., 2006. Advection influences on evapotranspiration of alfalfa in a semiarid climate. Agron. J. 98 (6), 1646-1654.

Jddin, J., Hancock, N.H., Smith, R.J., Foley. J.P., 2013. Measurement of evapotranspi ration during sprinkler irrigation using a precision energy budget (Bowen ratio eddy cova

Und, H.E., Houser, P.R., Shuttlew. H.th, W.J., Yang, Z.L., 1996. Sufface flux measurement and modeling at a semi-arid Sonoran Desert site. Agric. For. Meteorol. 82

(u, M., Kanber, R., Kapur, B., 2010. Comparison of soybean evapotranspirations measured by weighing lysimeter and Bowen ratio-energy balance methods. Afr.

entura, F., Spano, D., Duce, P.., Snyder, R.L., 1999. An evaluation of common evapo(163-170.

Scheduling for Water and Energy Conserv. in the 80 's, Chicago. American Society of Agricultural Engineers, St. Joseph, MI pp. $18-26$.

Wright, J.L., 1982. New vapotranspiration crop coefficients. J. Irrig. Drain. Div., ASCE 108 (IR2), 57-74

Xing, Z.S., Chow, L., Meng, F.R., Rees, H.W., Stevens, L., Monteith, J., 2008. Validating evapotranspiration equations using Bowen Ratio in New Brunswick, Maritime. Can. Sensors $8(1), 412-428$

Zeggaf, A.T., Takeuchi, S., Dehghanisanij, H., Anyoji, H., Yano, T., 2008. A Bowen ratio technique for partitioning energy fluxes between maize transpiration and soil surface evaporation. Agron. J. 100 (4), 988-996 


\subsection{Publicación 2}

\section{A digital image-processing-based method for determining the crop coefficient of lettuce crops in the southeast of Spain}

D.G. Fernández-Pacheco ${ }^{1}$, D. Escarabajal-Henarejos ${ }^{2}$, A. Ruiz-Canales ${ }^{3}$, J. Conesa ${ }^{1}$, J.M. Molina-Martínez ${ }^{2}$

${ }^{1}$ Departamento de Expresión Gráfica. Universidad Politécnica de Cartagena, Campus de la Muralla del Mar, C/ Doctor Fleming s/n, 30202 Cartagena, Murcia.

${ }^{2}$ Grupo de Investigación en Ingeniería Agromótica y del Mar. Universidad Politécnica de Cartagena, $\mathrm{P}^{\mathrm{o}}$ Alfonso XIII 52, 30203 Cartagena, Murcia.

${ }^{3}$ Departamento de Ingeniería. Universidad Miguel Hernández de Elche, Ctra. de Beniel $\mathrm{km} \mathrm{3.2,} 03312$ Orihuela, Alicante.

\section{RESUMEN}

En las regiones áridas y semiáridas del sureste de España, la baja disponibilidad de agua para el riego requiere el desarrollo de nuevas técnicas de conservación de agua de riego. Esto lleva a la utilización de las tecnologías de agricultura de precisión que permiten una mejora en el rendimiento o reducciones en el consumo de agua y fertilizantes. En este contexto, el uso de la fotografía digital permite la monitorización del crecimiento de las plantas, lo que permite determinar los requerimientos de agua de los cultivos a partir de variables que están directamente relacionados con la evapotranspiración. Una de estas 
variables es el porcentaje de cobertura del suelo, que también se ha correlacionado con la altura de la planta. En este trabajo se presenta un nuevo método basado en la visión artificial para estimar el coeficiente de cultivo $(K c)$ de los cultivos de lechuga a partir del porcentaje de cobertura del suelo $(P G C)$ extraído de fotografías digitales del cultivo. En contraste con otros métodos descritos en la literatura, la altura de la planta $(h)$ se calcula primero; a continuación, el término $P G C / h$ se correlaciona con $K c$. El método se aplicó con éxito y fue validado utilizando un cultivo comercial de lechuga (Lactuca sativa L. cv. 'Hierro'), ubicado en el sureste de España.

\section{INTRODUCCIÓN}

En el actual contexto económico, el objetivo de una explotación agrícola es obtener los máximos beneficios en un entorno social y económico. Esto significa, por un lado un uso más racional de los recursos ambientales (suelo-clima-agua) y por otro, el empleo de las técnicas de riego (Goncalves et al., 2011; Oron et al., 2002) y las técnicas de cultivo apropiadas. En el sureste de España, debido al clima semiárido de la región, la escasez generalizada de agua para la agricultura ha generado una fuerte necesidad de desarrollar estrategias que mejoren la eficiencia del uso del agua (Molina-Martinez et al., 2011).

En este contexto, la agricultura de precisión ha demostrado ser una solución para la mejora del uso del agua en los sistemas productivos, entre otros. Debido a los menores costes materiales y el desarrollo de nuevos sistemas de teledetección (Ahamed et al., 2012; Xiang y Tian, 2011), ha sido posible aplicar técnicas de procesamiento de imágenes digitales a la agricultura (Lorente et al., 2012).

En lo referente a la gestión eficiente del agua, el uso de la fotografía digital en la agricultura de precisión permite el monitoreo del crecimiento de las plantas, permitiendo así determinar las necesidades de agua de los cultivos en base a variables que están directamente relacionadas con la evapotranspiración $(E T c)$, que se calcula multiplicando el coeficiente de cultivo $(K c)$ por la evapotranspiración de referencia (ETo) (Allen et al., 1998).

Una de estas variables es el índice de área foliar (IAF), que predice la producción primaria fotosintética y es utilizado como una herramienta de referencia en el desarrollo del cultivo (Fortin et al., 2008). Como tal, el IAF desempeña un papel esencial en la producción ecológica teórica. Debido a que todos los métodos directos de medición del IAF son similares, en tanto que son extremadamente laboriosos, destructivos y costosos 
en términos de tiempo y dinero, se han desarrollado otros métodos indirectos de medición del IAF que implican menos procedimientos y en consecuencia menor tiempo de ejecución (Kirk et al., 2009). Por ejemplo, Lu et al. (2004) propusieron diversos modelos para estimar el área de una hoja de taro utilizando mediciones no destructivas de longitud y anchura, y Campillo et al. (2010) desarrollaron un sencillo y económico método para estimar el IAF en cultivos hortícolas utilizando el porcentaje de cobertura del suelo extraído de imágenes digitales. Esta relación entre el índice de área foliar y la cobertura del suelo también ha sido demostrada en patata por Boyd et al. (2002), quienes obtuvieron una alta correlación (lineal) incluso bajo extremos niveles de competencia y diferentes tipos de gestión.

Otra variable directamente relacionada con el concepto de evapotranspiración es el porcentaje de cobertura del suelo $(P G C)$, aunque algunos autores también utilizan el término 'proyección superior del área foliar' (TPLA) para indicar la proyección horizontal (equivalente a la sombra) cuando se observa desde una posición directamente desde la parte superior. Este parámetro normalmente se obtiene a partir de imágenes digitales utilizando técnicas de tratamiento de imagen, que proporcionan resultados precisos (Congling et al., 2005).

En estudios recientes, se ha puesto de manifiesto en cultivos hortícolas una fuerte relación entre la proyección superior del área foliar y otros parámetros. Por ejemplo, Giacomelli et al. $(1996,1998)$ fueron capaces de determinar el estrés de nutrientes en plantas de lechuga empleando un sistema de visión artificial que obtiene el TPLA de plántulas de lechuga; Ling y Ruzhitsky (1992) encontraron una fuerte correlación entre peso fresco, peso seco y TPLA obtenido utilizando tecnología de procesamiento de imágenes en plántulas de tomate; Blasco et al. (2002) desarrollaron un sistema robótico basado en el análisis de imágenes para eliminar las malas hierbas en campos de lechuga basado en el tamaño del área proyectada; y Story et al. (2010) diseñaron un sistema de visión artificial para detectar la deficiencia de calcio en cultivos de lechuga bajo invernadero empleando cambios morfológicos, temporales y de color en la planta, tales como TPLA.

Además, el porcentaje de cobertura del suelo también ha sido correlacionado con la altura de la planta, proporcionando resultados satisfactorios en arbustos ornamentales (Grant et al., 2012), trigo de invierno (Xu et al., 2010) y plantas de humedales construidos (Xiao et al., 2011), entre otros. Debido a que la altura de la planta está directamente 
relacionada con las etapas de desarrollo del cultivo, se ha estudiado la relación directa entre el coeficiente de cultivo $K c$ y el porcentaje de cobertura del suelo para diversos sistemas de riego, obteniéndose resultados satisfactorios en tomate (Hanson y May, 2005), fríjol (De Medeiros et al., 2001) y cebolla (López-Urrea et al., 2009). Sin embargo, estudios llevados a cabo en cultivos de lechuga obtuvieron malas estimaciones (Allen y Pereira, 2009; Grattan et al., 1998).

En este trabajo, se propone un nuevo y sencillo método basado en el procesamiento de imágenes digitales para la estimación del coeficiente de cultivo en cultivos de lechuga a partir de fotografías digitales de la cubierta vegetal. En contraste con otros métodos propuestos en la literatura, primero se calcula $P G C$, que posteriormente es utilizado para estimar la altura de la planta $(h)$; a continuación, el término $P G C / h$ se correlaciona con el coeficiente de cultivo $K c$. Este método ha sido aplicado y validado en un cultivo comercial de lechuga (Lactuca sativa L. cv. 'Hierro'), ubicado en el sureste de España, obteniéndose resultados satisfactorios.

\section{MATERIALES Y MÉTODOS}

Los objetivos del método propuesto son calcular el coeficiente de cultivo $K c$ en cultivos de lechuga, basado en una secuencia de fotografías digitales de la cubierta vegetal. El valor de $K c$ puede ser utilizado para estimar las necesidades de agua del cultivo analizado, con razonable precisión y ser introducido en un sistema de programación del riego.

El método consta de tres fases bien diferenciadas (Fig. 1.1): i) una primera fase (o 'fase de modelado') en la que se desarrollan las ecuaciones matemáticas que relacionan el porcentaje de cobertura del suelo (extraído a partir de imágenes digitales), la altura de la planta (medida en campo) y el coeficiente de cultivo $K c$ (obtenido a partir de los datos suministrados por una estación Bowen) a lo largo de las etapas de desarrollo del cultivo, ii) una segunda fase (o 'fase de validación') en la que se validan las ecuaciones mediante contraste con los valores estimados y medidos de altura de la planta y coeficiente de cultivo $K c$, y iii) una tercera fase (o 'fase de aplicación') en la que se utilizan directamente las ecuaciones para estimar el coeficiente $K c$ a partir de imágenes digitales del cultivo.

Una vez que ha sido ejecutada la fase de modelado y se han obtenido las ecuaciones matemáticas, puede llevarse a cabo a cabo directamente la fase de aplicación. Sin embargo, se recomienda que la validación se realice después de un número determinado 
de cultivo temporadas para verificar la calidad de las estimaciones y ajustar las ecuaciones si resulta necesario.

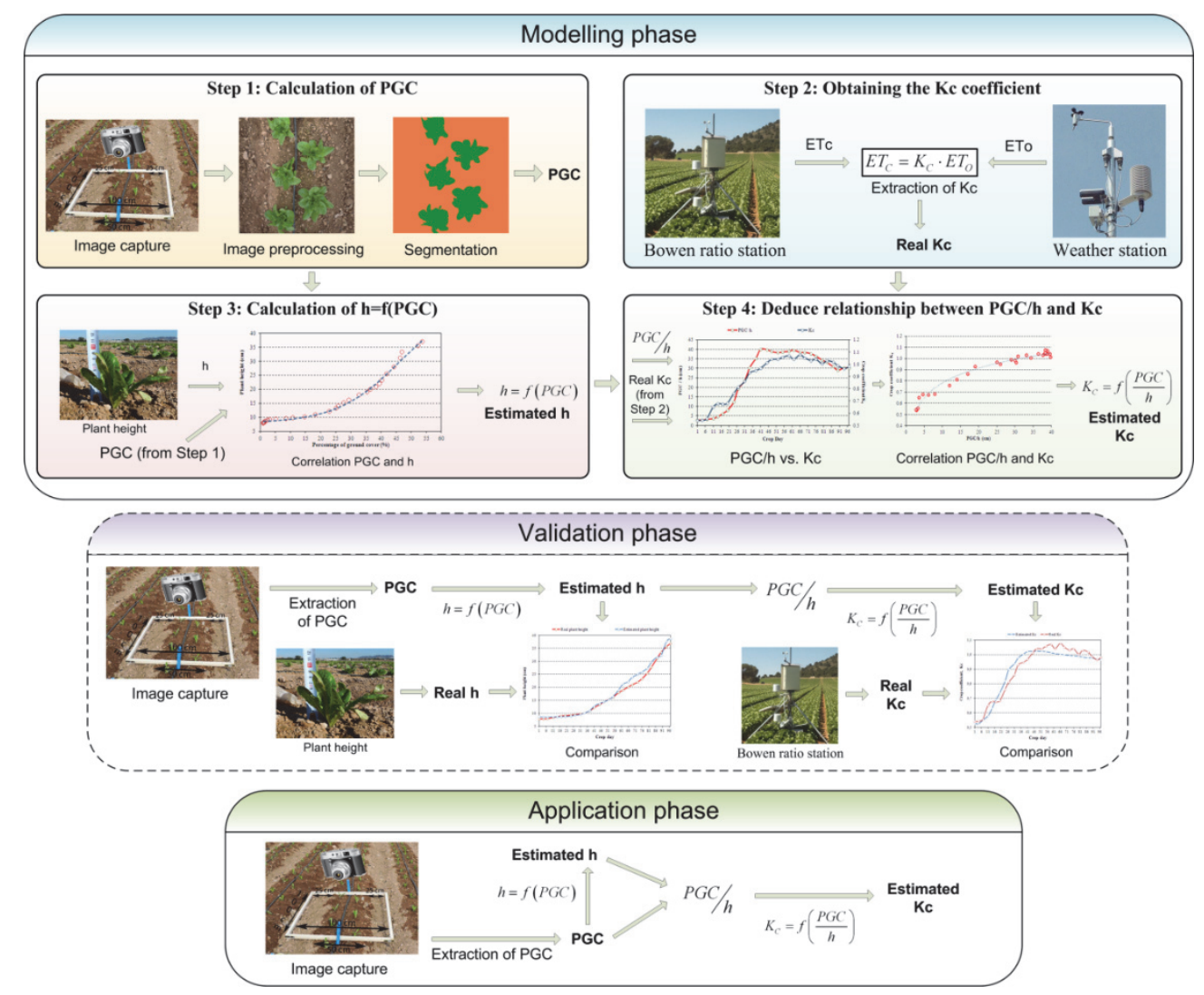

Fig. 1.1. Esquema de la metodología propuesta ilustrando las diversas fases y procesos.

\subsection{Parcela experimental}

El método fue desarrollado durante un periodo de 97 días desde octubre de 2010 hasta febrero de 2011, sobre un cultivo comercial de lechuga (Lactuca sativa L. cv. 'Hierro') ubicado en Fuente Álamo (latitud 37\%42'35' 'N, longitud $1^{\circ} 10^{\prime} 20^{\prime}$ ' W y altitud $125 \mathrm{~m}$ ), provincia de Murcia, España. La parcela tiene una superficie aproximada de 6,5 ha, con plantas colocadas sobre surcos de $50 \mathrm{~cm}$ de ancho y orientados en la dirección norte-sur, dispuestas al tresbolillo con una densidad de plantación de 5 plantas $\cdot \mathrm{m}^{-2}$. La parcela está equipada con un sistema de riego localizado mediante mangueras de polietileno de 16 $\mathrm{mm}$ con goteros interlínea de $4 \cdot 1 \cdot \mathrm{h}^{-1}$ espaciados $0,60 \mathrm{~m}$. El tipo de suelo es clasificado como "Calcixeroll" formado sobre materiales limosos carbonatados y textura franca.

El clima de la zona es Mediterráneo subdesértico, con temperaturas suaves en invierno, que oscilan entre los $10-12^{\circ} \mathrm{C}$, y un verano caluroso con temperaturas entre los $24-27^{\circ} \mathrm{C}$. La temperatura media anual es aproximadamente $17,5^{\circ} \mathrm{C}$. Esta termicidad hace raras las heladas y casi imposibles las nevadas. Las precipitaciones están distribuidas 
irregularmente y ocurren predominantemente entre otoño y primavera. Los niveles de precipitación fueron registrados empleando un pluviómetro RAIN-O-MATIC (Campbell Scientific, Logan, UT, EE.UU.), el cual estaba incluido en una estación meteorológica situada en la parcela experimental. En el periodo en el que se realizó la primera fase de modelado, no se presentaron precipitaciones en el 79\% de los días. En el resto de días, se registraron niveles de precipitación de 0,5-0,9 $\mathrm{mm} \cdot \mathrm{d}^{-1}$ (agrupados en intervalos de 2-3 días). El valor medio de precipitación se excedió sólo tres días, alcanzando valores de $22,6 \mathrm{~mm} \cdot \mathrm{d}^{-1}$. Durante la fase de modelado, la cantidad total de lluvia no superó los 70 $\mathrm{mm}$. Los patrones de distribución e intensidad fueron muy similares durante las fases de validación y llegaron a un máximo de $85 \mathrm{~mm}$ en cada período.

\subsection{Fase de modelado}

\subsubsection{Cálculo del porcentaje de cobertura del suelo}

La fase de modelado se inicia con el cálculo del porcentaje de suelo cubierto por las plantas, siendo este parámetro la entrada principal del método propuesto. Debido a que la parcela experimental puede ser dividida en subparcelas iguales de $1 \mathrm{~m} \mathrm{x} 1 \mathrm{~m}$ (Fig. 1.2), las fotografías digitales de la cubierta vegetal fueron tomadas sobre 4 subparcelas de muestreo de $1 \mathrm{~m}^{2}$, elegidas al azar como representativas del cultivo, evitando la zona externa de la plantación para eliminar el efecto borde. Las subparcelas estaban convenientemente señalizadas mediante estacas ubicadas en la parte central del caballón, que servían de referencia para ubicar un marco de 1 x $1 \mathrm{~m}$ que delimitaba la parcela, pues representaban el punto medio de uno de los lados del marco (ver detalle en Fig. 1.2). Las fotografías se realizaron a partir del primer día de trasplante a intervalos de 2-3 días, en cada una de las subparcelas muestreadas, lo que supuso la obtención de 116 imágenes.

Las fotografías se realizaron verticalmente sobre el cultivo a una altura fija de 1,40 m sobre el nivel del suelo, mediante el empleo de una cámara digital (Lumix DMC-LX3, Panasonic, Japón) equipada con un dispositivo de carga acoplado (CCD) (resolución, 10,1 megapíxeles; distancia focal, $24 \mathrm{~mm}$ ) que estaba montada sobre un trípode. Para hacer coincidir la fracción de suelo cubierto por vegetación con la fracción de área sombreada por la planta, las fotografías fueron tomadas al mediodía solar. Es recomendable tomar varias fotografías de cada subparcela y posteriormente seleccionar la mejor toma (es decir, aquellas fotografías que no muestren defectos de luminosidad o concavidad y estén correctamente enmarcadas). 


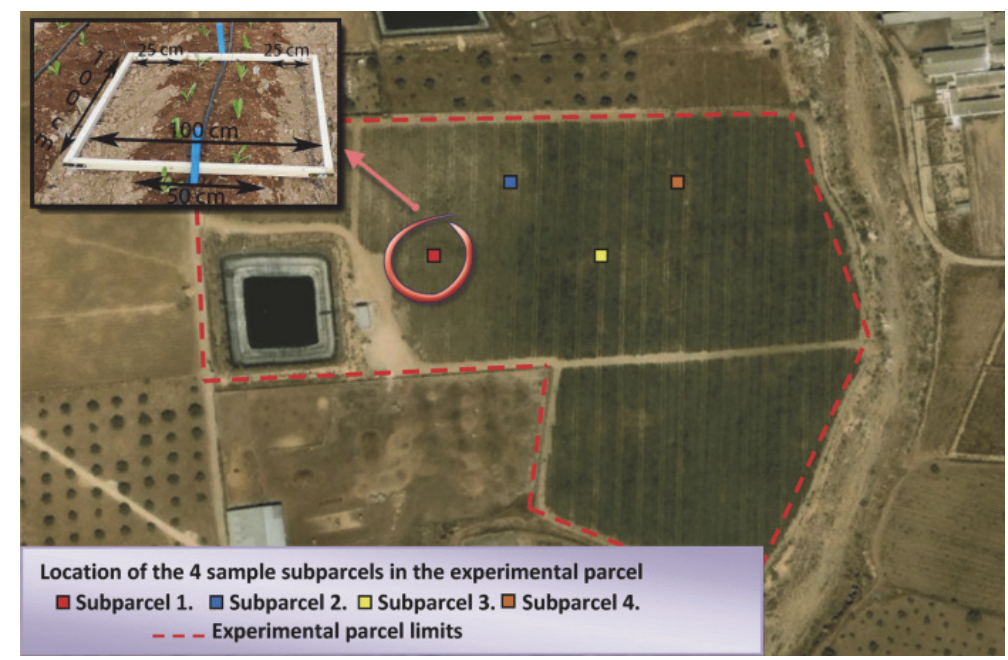

Fig. 1.2. Ubicación de las cuatro subparcelas de muestreo en la parcela experimental y un ejemplo del marco de $1 \mathrm{~m}$ x $1 \mathrm{~m}$ utilizado para la toma de imágenes.

Tras tomar las fotografías de las cuatro subparcelas de muestreo y seleccionar las mejores tomas, las imágenes fueron pre-procesadas digitalmente de tal manera que sólo se dejó el interior del marco (Fig. 1.3). Para este fin se puede utilizar cualquier software de edición de fotografía disponible en el mercado. Debido a que el método aquí propuesto calcula la cobertura del suelo en forma de porcentaje (más que el número de píxeles), la resolución final de la imagen no afectará a los resultados; el método es, por lo tanto escalainvariante. En otras palabras, ya que el porcentaje divide el número de píxeles de vegetación por el número total de píxeles de la imagen, esta proporción seguirá siendo la misma aunque la imagen se escale.

Las imágenes pre-procesadas fueron posteriormente procesadas usando el software ENVI $^{\circledR}$ (Environment for Visualizing Images) (Research System Inc., Boulder, CO, EE.UU.), que proporciona un entorno fácil de utilizar para mostrar y analizar imágenes de cualquier tamaño y tipo de datos.

La primera fase fue la segmentación de la imagen para discriminar entre suelo (beige) y vegetación (verde). El software permite definir esas dos clases y seleccionar las regiones de interés (ROIs) en la imagen que se referían a la misma clase (Fig. 1.3). Una vez se definieron estas ROIs, la imagen fue segmentada utilizando una clasificación supervisada de máxima similitud de la imagen en función de las ROIs definidas (Fig. 1.3). Tras la segmentación, se obtuvieron el número de píxeles de la imagen correspondientes a vegetación $(\mathrm{V})$, a suelo $(\mathrm{S})$ y totales $(\mathrm{T})$, siendo utilizados posteriormente para calcular el porcentaje de cobertura del suelo como la relación $\mathrm{V} / \mathrm{T}$. 

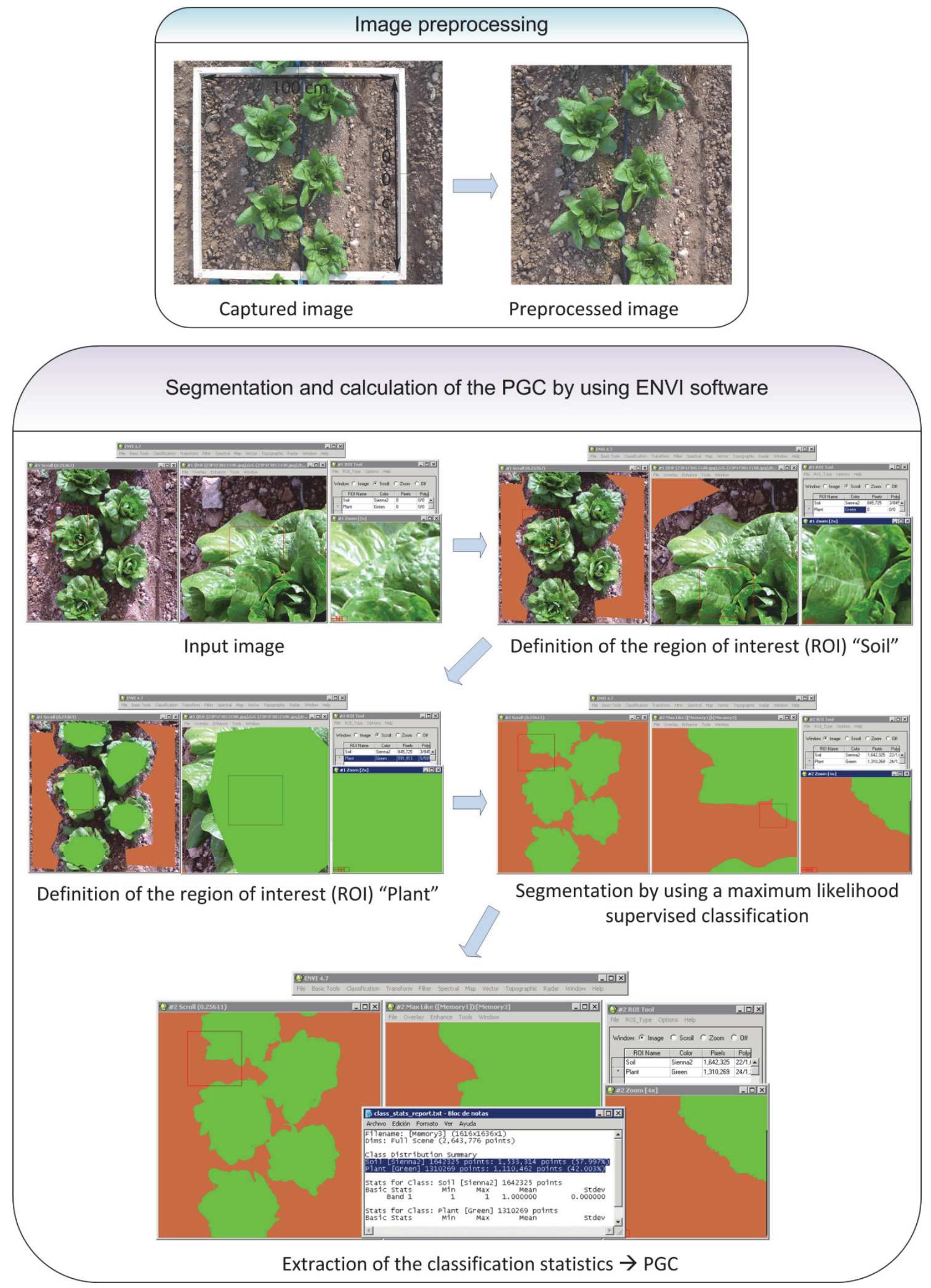

Fig. 1.3. Pre-procesado, segmentación y obtención de PGC.

Una vez obtenido el porcentaje de cobertura del suelo para cada subparcela, se calculó el valor promedio de las 4 subparcelas para cada día de muestreo (Fig. 1.4). 


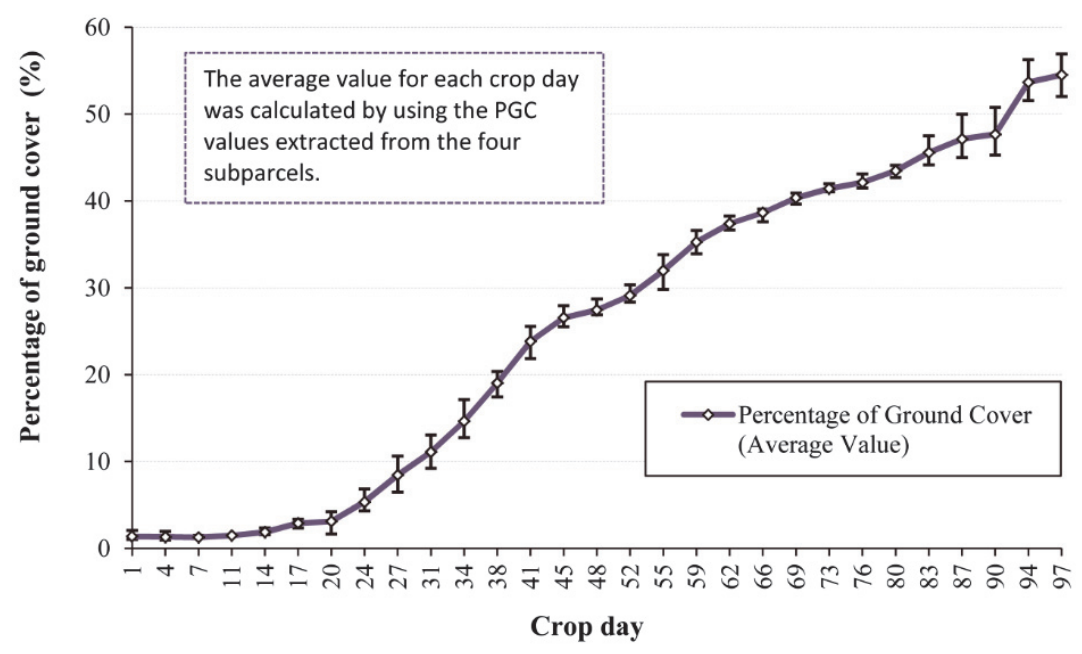

Fig. 1.4. Porcentaje de cobertura del suelo medio y error estándar para cada día de cultivo.

\subsubsection{Obtención del coeficiente $K c$ empleando una estación Bowen}

De acuerdo con la metodología de la Organización para la Agricultura y la Alimentación de las Naciones Unidas (FAO) (Doorenbos y Pruitt, 1977), la evapotranspiración de un cultivo está directamente relacionada con la evapotranspiración de referencia por un coeficiente de cultivo, que refleja la relación entre las propiedades de las plantas y sus necesidades de agua:

$$
E T c=K c \cdot E T o
$$

Este coeficiente de cultivo $K c$ se considera un ' $K c$ global' y también incluye las variaciones en las etapas tempranas del desarrollo dependiendo de las condiciones locales y tipo de riego empleado, entre otros (Allen et al., 2011). Estas variaciones deben ser consideradas si el coeficiente de cultivo calculado utilizando esta metodología se aplica a otros cultivos de lechuga.

Para este estudio, los valores de evapotranspiración de referencia (ETo) fueron calculados a partir de las variables climáticas registradas por una estación meteorológica ubicada en la parcela experimental, y aplicando la ecuación de Penman-Monteith FAO56 (Allen et al., 1998). La evapotranspiración del cultivo (ETc) fue calculada aplicando el método de la Razón de Bowen-Balance de Energía (RBBE). Para este propósito, se instaló una estación Bowen en el centro de la parcela. El método está basado en el balance de energía, forzando su cierre mediante el empleo de la relación $H / \lambda E$, conocida como razón de Bowen (Bowen, 1926); esta relación informa sobre el reparto de la energía disponible en la superficie entre los flujos de calor sensible $(H)$ y latente $(\lambda E)$. Una 
aproximación razonable a la ecuación de balance de energía en la superficie puede escribirse en términos de densidades de flujo como:

$$
R_{n}-G=\lambda E+H
$$

donde $R_{n}$ es la radiación neta y $G$ define el flujo de calor en el suelo. Los flujos $\mathrm{H}$ y $\lambda E$ son estimados como una función de la razón de Bowen, la cual se calcula empleando los gradientes de flujo:

$$
\beta=\frac{H}{\lambda E}=\gamma \frac{\Delta T}{\Delta q}
$$

donde $\gamma$ es la constante psicrométrica y $\Delta T$ y $\Delta q$ son los gradientes de temperatura y presión de vapor de agua, respectivamente, medidos entre dos niveles dentro de la capa límite. Esto permite calcular el término del balance de energía correspondiente a la evapotranspiración del cultivo $(\lambda E)$ empleando la siguiente ecuación:

$$
\lambda E=\frac{R_{n}-G}{1+\beta}
$$

La estación Bowen empleada durante este estudio estaba equipada con un radiómetro neto modelo NR-LITE (Campbell Sci. Inst., EE.UU.), ubicado a $2 \mathrm{~m}$ sobre el suelo. Ambos gradientes fueron evaluados con sensores situados en dos brazos, dispuestos en el sentido de la hilera de plantas y separados $45 \mathrm{~cm}$ entre sí. El brazo inferior se ubicó $50 \mathrm{~cm}$ por encima de la parte superior de la vegetación. El gradiente de temperatura se evaluó empleando dos termopares de hilo fino tipo E (cromo-constantan) modelo ASPTC (Campbell Sci. Inst., EE.UU.), y el gradiente de humedad fue obtenido empleando un higrómetro de espejo de punto de rocío modelo ALMEMO-FHA64DTC1 (Ahlborn Mess, und R., Alemania). La estación también esta equipada con un datalogger modelo CR1000 (Campbell Sci. Inst., EE.UU.), que registró las variables necesarias para el uso del método BREB. Los datos obtenidos de la estación Bowen fueron sometidos a los controles de calidad propuestos por Ohmura (1982) para garantizar la calidad de los datos.

Considerando todos los puntos anteriores, se calculó el coeficiente $K c$ para cada uno de los días muestreados empleando la ecuación [1] y los valores de ETo y ETc obtenidos a partir de las respectivas estaciones (Fig. 1.5). 


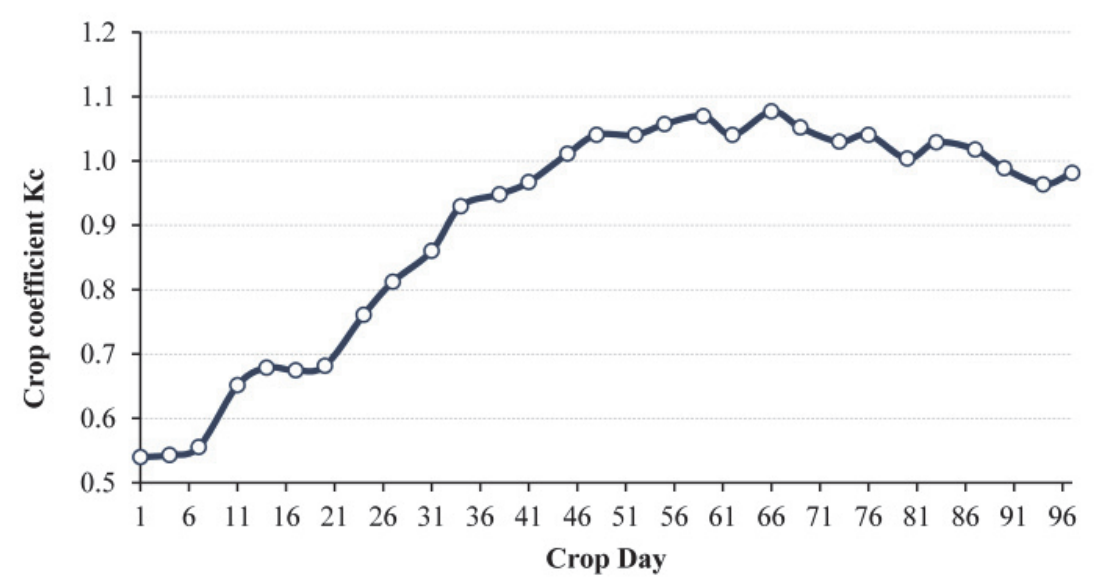

Fig. 1.5. Coeficientes de cultivos calculados a partir de los valores proporcionados por las estaciones.

\subsubsection{Estimación de la altura de la planta}

Cada día muestreado, mientras se tomaron fotografías de las subparcelas, se midió la altura de todas las plantas incluidas en cada subparcela para determinar una posible relación entre la altura de la planta y el porcentaje de cobertura del suelo. El valor medio de cada subparcela fue calculado posteriormente, como el valor medio de todas las subparcelas (Fig. 1.6).

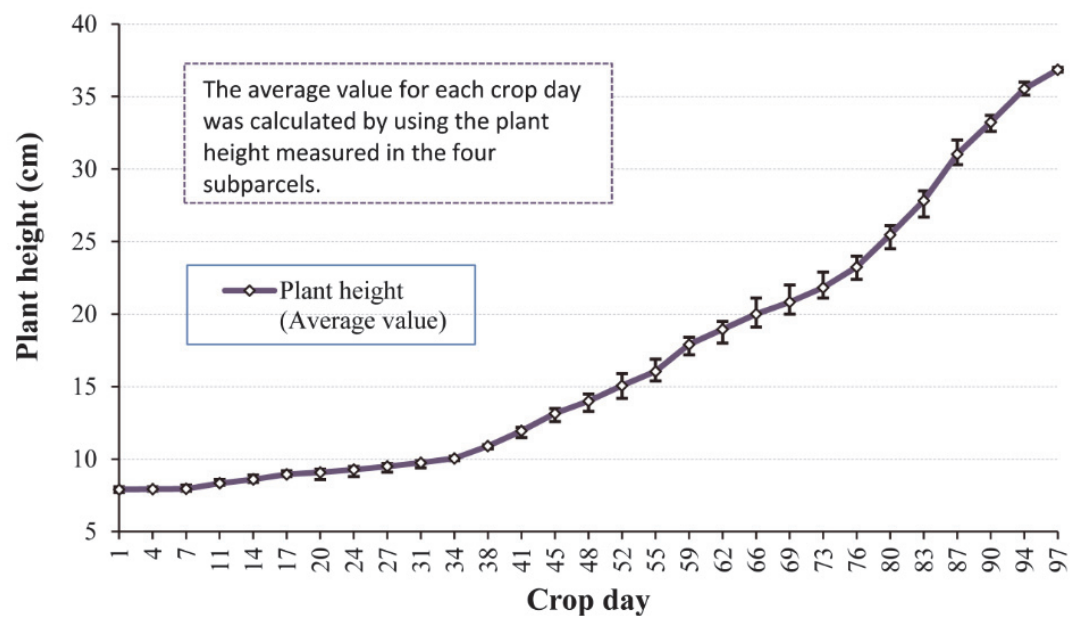

Fig. 1.6. Altura media de la planta y error estándar para cada día de cultivo.

Los valores medios de porcentaje de cobertura del suelo y altura de la planta para cada día de muestreo mostraron una distribución similar (Fig. 1.7a). Esto condujo al establecimiento de una relación entre ambos parámetros; relación que fue descrita por medio de una función (Fig. 1.7b). Esta función permitió estimar la altura de la planta a partir del porcentaje de cobertura del suelo obtenido de la imagen digital de una subparcela. Para el estudio presentado, se analizaron varias funciones de aproximación, 
incluyendo doble sigmoide, logística, Gompertz y funciones monomoleculares. La función doble sigmoide produjo los mejores resultados.

\subsubsection{Estimación de la altura de la planta}

El coeficiente de cultivo $K c$ se estimó a partir del cociente $P G C / h$. Estos dos parámetros se muestran en la Fig. 1.8a, donde se aprecia una distribución similar que fue utilizada para obtener una función logarítmica que relacione el parámetro $P G C / h$ con el coeficiente de cultivo $K c$ (Fig. 1.8b).

\subsection{Fase de validación}

Una vez obtenidas las ecuaciones que relacionan $P G C / h$ y $K c$, éstas fueron validadas durante las siguientes temporadas de cultivo. Durante esta fase de validación, se llevaron a cabo los siguientes pasos:

i) Se seleccionaron cuatro nuevas subparcelas de muestreo y se fotografiaron, y el porcentaje de cobertura del suelo fue obtenido de la misma manera que en la fase de modelado.

ii) Al mismo tiempo que se tomaron las fotografías, se midieron las alturas de las plantas; después se calculó la altura media de todas las plantas en las cuatro subparcelas.

iii) Usando el valor medio de $P G C$ extraído de las cuatro subparcelas y la ecuación obtenida durante la fase de modelado, se obtuvo una estimación de altura de la planta.

iv) La altura de la planta estimada se comparó con la altura medida, y se obtuvieron datos estadísticos.

v) Empleando el valor de $P G C$ dividido entre la altura de la planta estimada y la segunda ecuación que obtenida durante la fase de modelado, se estimó $K c$.

vi) Coincidiendo con la toma de imágenes y la medición de la altura de la planta, se obtuvieron los valores de ETc a partir de la estación Bowen y los valores de ETo de la estación meteorológica, para calcular el valor real de $K c$.

vii) Los valores estimados de $K c$ fueron comparados con los valores reales de $K c$, y se obtuvieron datos estadísticos.

El proceso de validación se realizó en la misma parcela donde se calcularon las ecuaciones debido a que el valor de $K c$ se ve afectado por diversas condiciones 
ambientales que pueden variar entre cultivos. Los resultados del proceso de validación obtenidos durante este estudio se muestran en el siguiente capítulo.

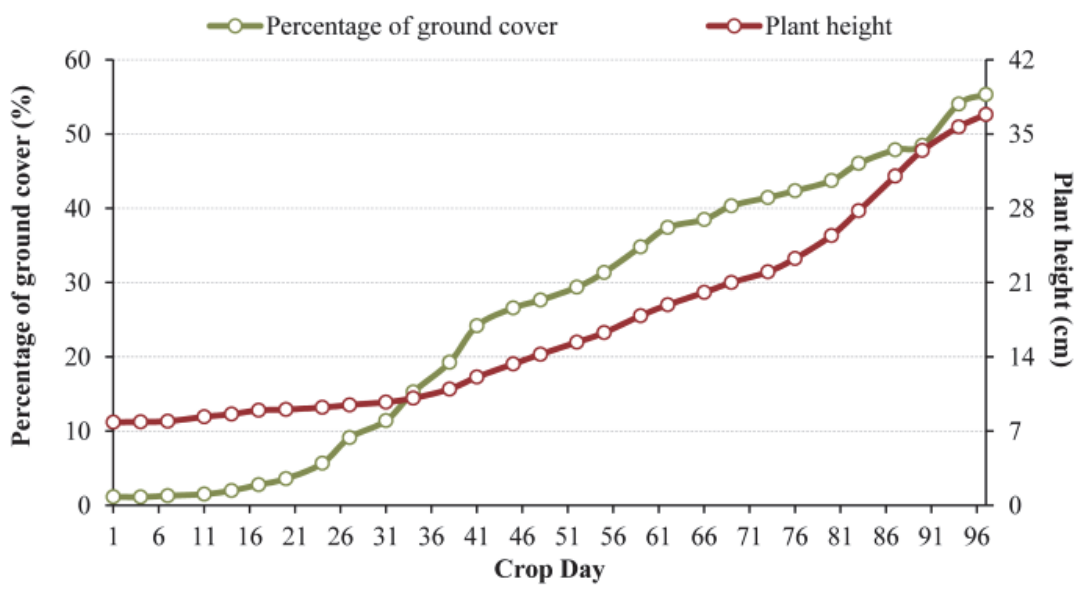

a)

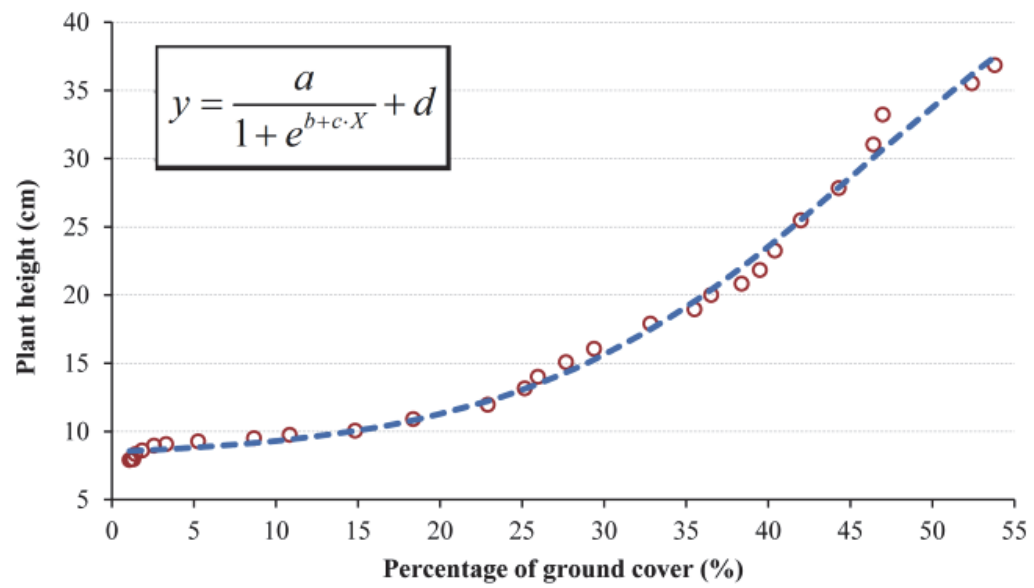

b)

Fig. 1.7. a) Comparación entre altura de la planta y porcentaje de cobertura del suelo. b) Análisis de correlación.

\subsection{Fase de aplicación}

Para proveer al usuario final de una metodología para estimar las necesidades hídricas del cultivo de lechuga, se ha definido una fase de aplicación directa. Esta fase se ejecuta después de la fase de modelado para las siguientes campañas agrícolas. Durante esta fase, se ejecutan los siguientes procesos:

i) Debe seleccionarse y fotografiarse una subparcela de muestreo, representativa de toda la superficie cultivada, y calcular el porcentaje de cobertura del suelo de la misma manera que durante la fase de modelado. 
ii) Empleando el valor de $P G C$ extraído de la subparcela seleccionada y la ecuación obtenida durante la fase de modelado, debe obtenerse una estimación de la altura de la planta.

iii) Al dividir el valor de $P G C$ entre la altura estimada de la planta, y empleando la segunda ecuación obtenida durante la fase de modelado, se lograría una estimación de $K c$.

Estos pasos permitirían estimar el coeficiente de cultivo $K c$ para el cultivo de lechuga estudiado empleando sólo una cámara digital y técnicas de procesamiento de imágenes.

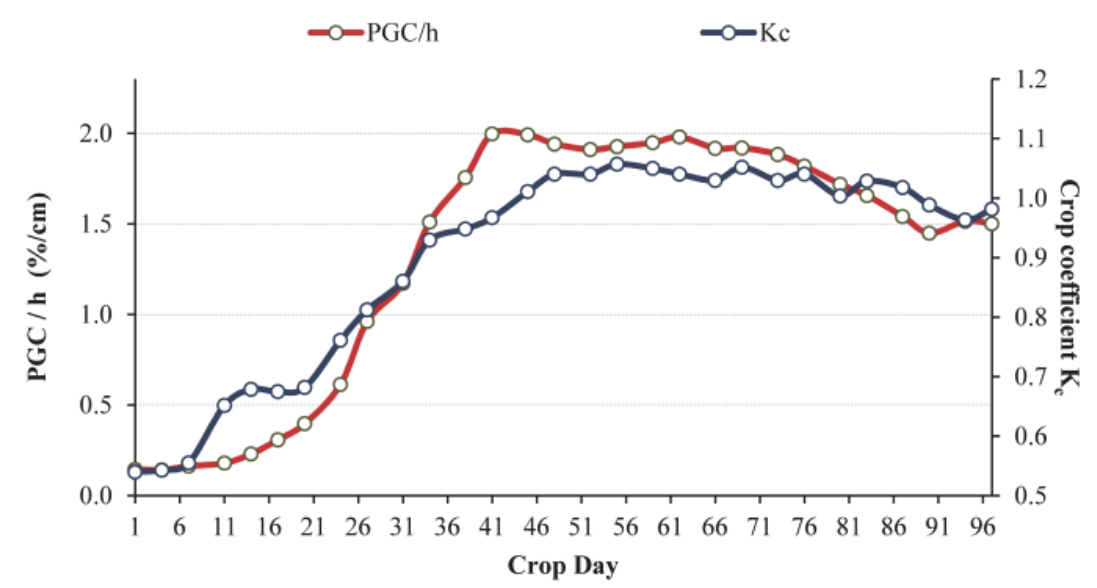

a)

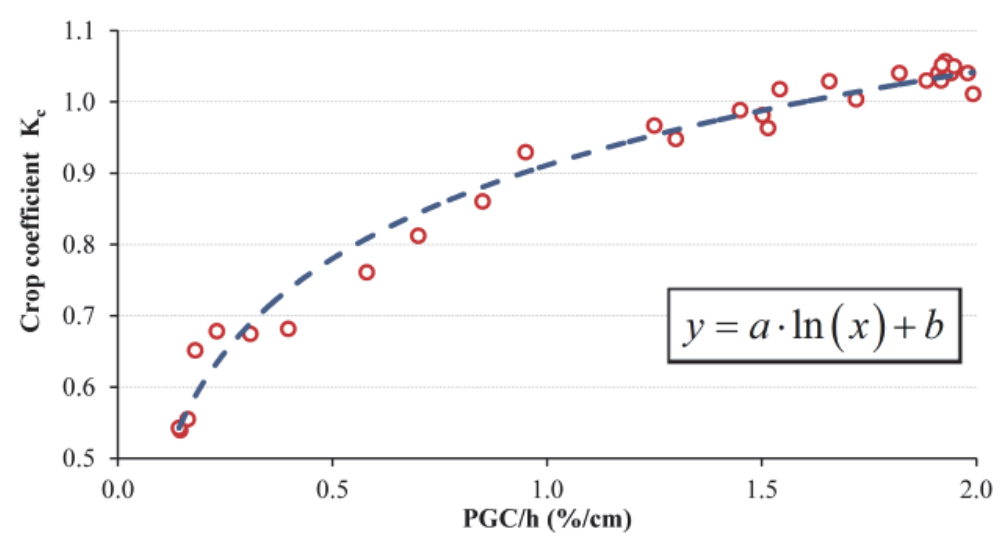

b)

Fig. 1.8. a) Comparación entre el parámetro $P G C / h$ y $K c$. b) Análisis de correlación.

\section{RESULTADOS}

Durante el experimento, la fase de modelado descrita en el capítulo anterior fue llevada a cabo en primer lugar. En el primer paso, se calculó el porcentaje de cobertura del suelo 
empleando una cámara digital y software de procesamiento de imágenes. La Fig. 1.9 muestra algunos resultados del proceso de segmentación para los días 1, 27, 55 y 97 de cultivo. El porcentaje de cobertura del suelo calculado y la altura de la planta medida también se indica, mostrando el crecimiento de las plantas. Se puede observar que el proceso de adquisición de datos comienza el primer día, lo que se corresponde con la fase durante la cual los requerimientos de agua de la planta eran pequeños. El día 27 coincide con un aumento de la demanda de agua, lo que indica que la planta sufre debido a la fase de pre-nutrición y enriquecimiento. El día 55 se corresponde con la fase de máxima demanda de agua y coincide con el inicio de la etapa de máximo crecimiento de las plantas. Finalmente, el día 97 representa el final de la temporada; en este momento, disminuye la demanda de agua.

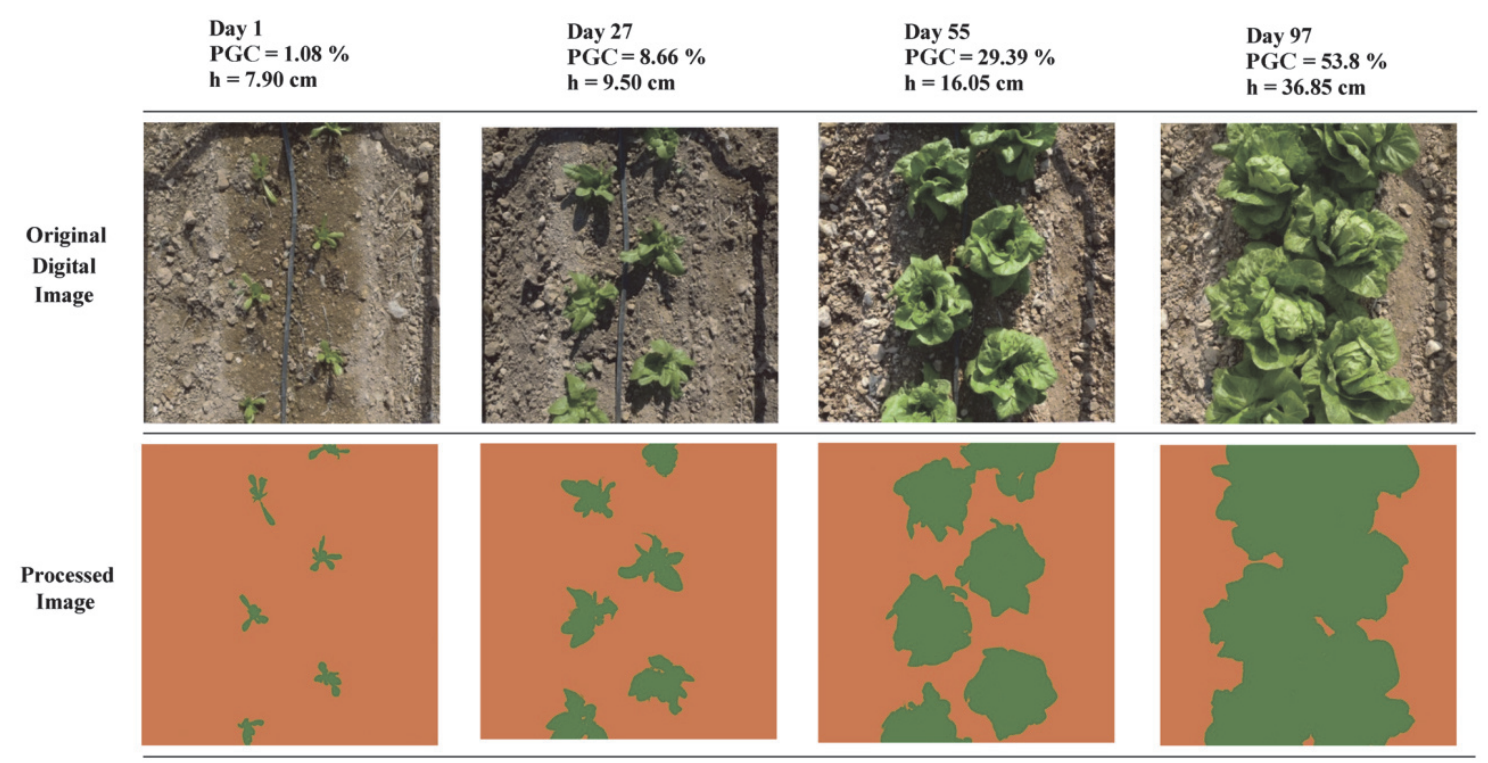

Fig. 1.9. Ejemplo de los resultados obtenidos empleando el software de procesamiento de imágenes.

En el segundo paso, se obtuvo el coeficiente de cultivo $K c$ utilizando la ecuación [1], y los datos fueron obtenidos empleando una estación Bowen y una estación meteorológica, ambas ubicadas dentro de la parcela experimental. El coeficiente de cultivo $K c$ puede representarse como un valor diario o como un valor medio temporal, que se calcula para las diversas etapas de crecimiento del cultivo (Fig. 1.10). Utilizando los criterios establecidos por Allen et al. (1998), los valores obtenidos se clasificaron en tres períodos de acuerdo a la etapa de requerimientos de evapotranspiración del cultivo: una fase inicial con el valor mínimo de $K c$, una fase intermedia en la que el cultivo alcanza el nivel máximo de evapotranspiración, y una fase final con un valor final de $K c$ que se encuentra entre los dos valores anteriores. 


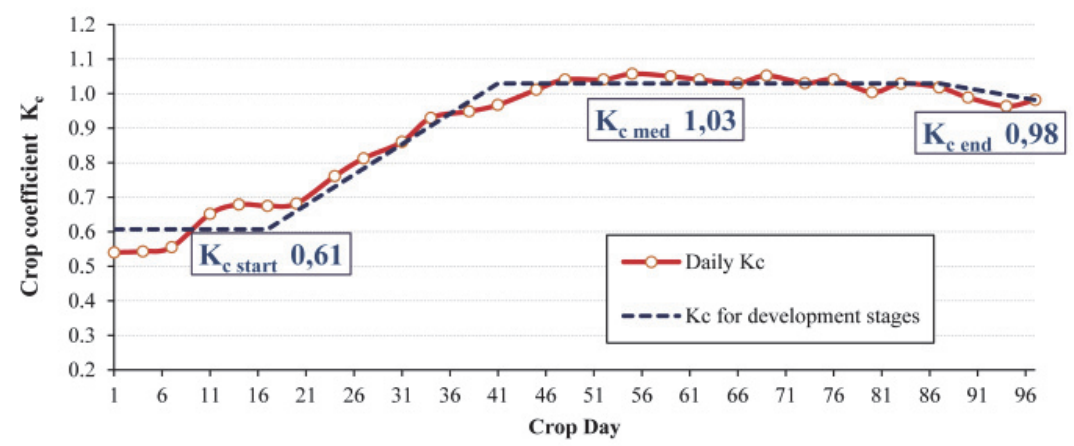

Fig. 1.10. Valores diarios y medios temporales de $K c$ (fase de modelado).

En el tercer paso, se obtuvo una ecuación que correlaciona el porcentaje de cobertura del suelo obtenido en el primer paso y la altura de la planta. Para este experimento, se analizaron varias funciones de aproximación, incluyendo la doble sigmoide, logística, Gompertz y funciones monomoleculares. Los mejores resultados se obtuvieron utilizando una función de doble sigmoide (Ec. 5), donde $y=h(\mathrm{~cm}), x=P G C$ (\%), $a=-43,42, b=-4,436, c=0,096 \mathrm{y} d=51,421$. Estos valores proporcionaron un coeficiente de correlación de 0,993 .

$$
y=\frac{a}{1+\mathrm{e}^{b+c \cdot x}}+d
$$

Para evaluar el comportamiento de la ecuación, se compararon los valores de altura de la planta medidos y estimados empleando la Ec. 5 (Fig. 1.11a). También se realizó un análisis de regresión lineal, obteniendo una pendiente de la recta de regresión lineal muy similar a $1(1,054)$ y un coeficiente de correlación $\mathrm{R}^{2}$ de 0,990 (Tabla 1.1). La raíz cuadrada del error cuadrático medio (RMSE) fue de 1,293, lo que demuestra que la diferencia entre los valores reales y los valores pronosticados por el modelo fue mínima.

La altura de la planta fue sobreestimada desde el día 55 al 90 (Fig. 1.11a). Esta sobreestimación puede ser debida a que el valor medido de $P G C$ fue menor que el valor estimado por la ecuación (Ec. 5). En este caso, el modelo obtenido no tuvo en cuenta que, durante esta etapa, el $P G C$ no puede adoptar valores superiores al 30\% durante el día 55 o superiores a 49\% durante el día 90. Sin embargo, el error obtenido no excedió del 10\% en el peor de los casos (durante el día 73).

En el paso final, la relación entre el parámetro $P G C / h$ y el coeficiente de cultivo $K c$ permitió obtener una función logarítmica que correlacionó ambos (Ec. 6), donde $y=K c$, $x=P G C / h(\% / \mathrm{cm}), a=0,189$ y $b=0,911$. Estos valores proporcionaron un coeficiente de correlación de 0,979 . 


$$
y=a \cdot \ln (x)+b
$$

Los valores estimados de $K c$ empleando esta ecuación fueron comparados con los valores reales de $K c$ obtenidos en el segundo paso (Fig. 1.11b); se realizó un análisis de regresión lineal (Tabla 1.1), obteniéndose una pendiente de la recta de regresión lineal muy similar a $1(0,966)$ y un coeficiente de correlación $\mathrm{R}^{2}$ de 0,977 . El valor obtenido de RMSE fue 0,027 .
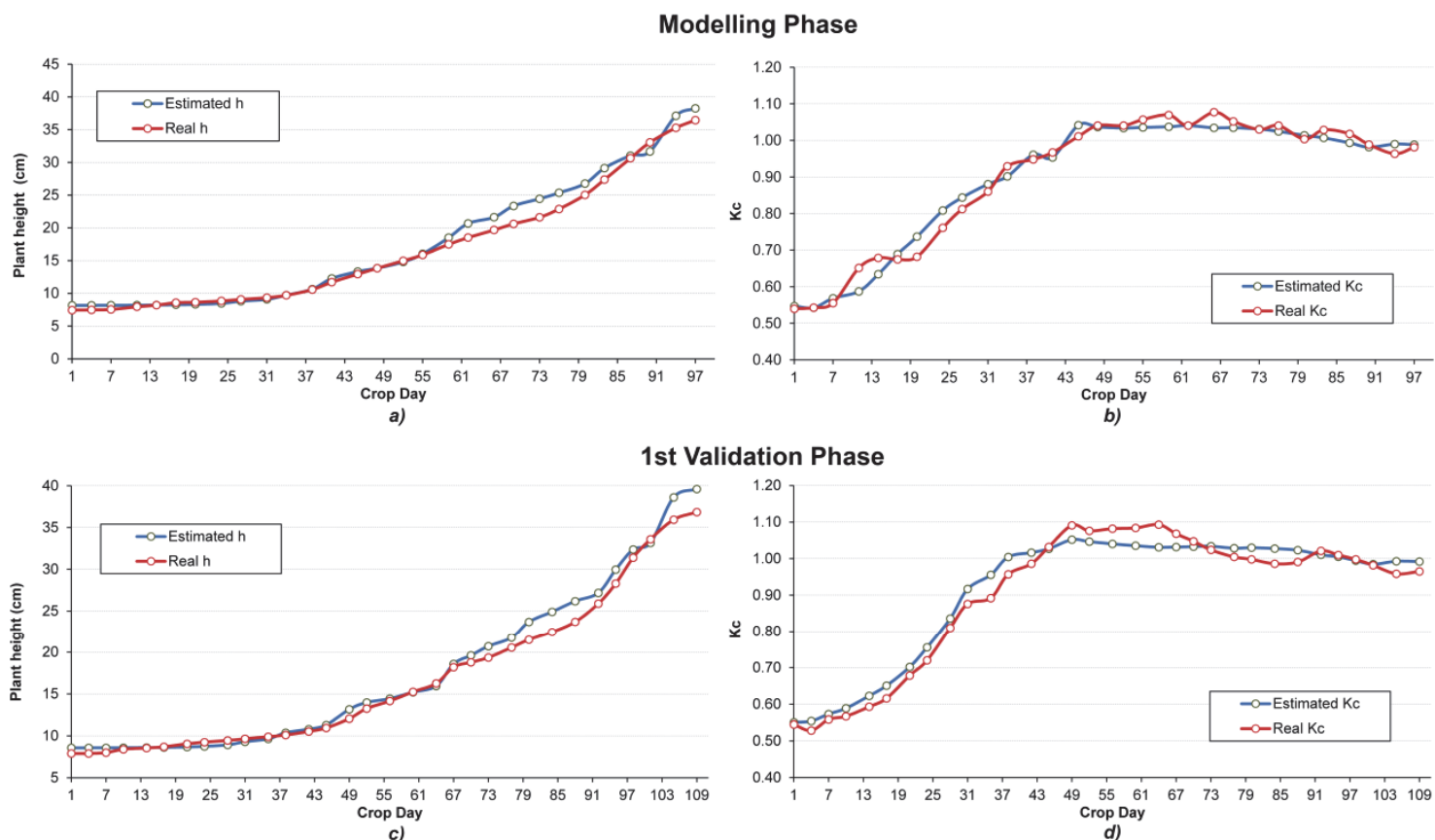

2nd Validation Phase
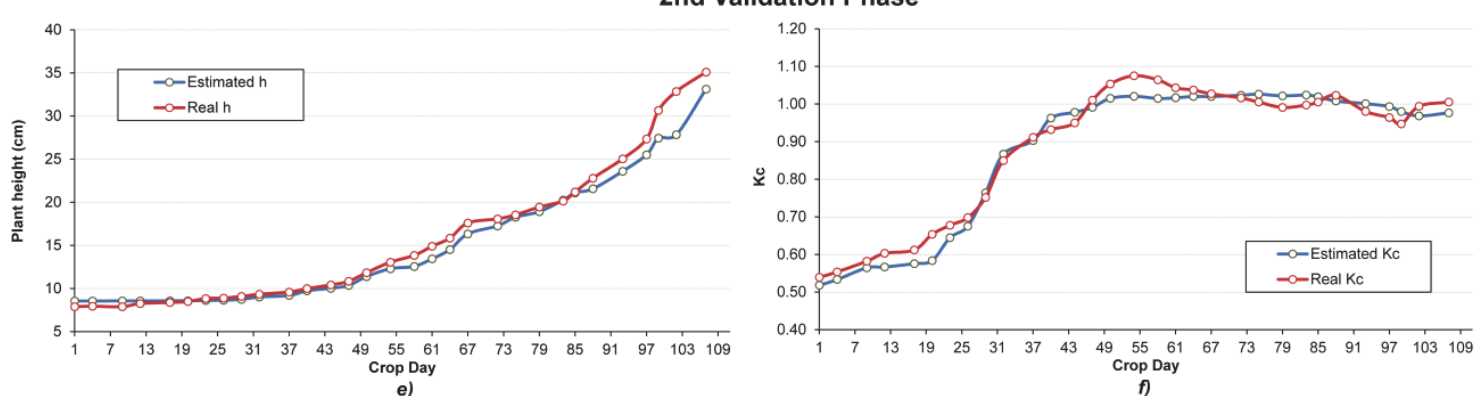

Fig. 1.11. Comparación de los valores reales y estimados de altura de la planta y $K c$ durante las fases de modelado y validación.

La Fig. 1.12 muestra la comparación adicional de los promedios temporales de $K c$. En esta figura se comparan los valores medios propuestos por FAO-56 (Allen et al., 1998) para cultivos de lechuga en clima Mediterráneo con los valores medios de los coeficientes de cultivo reales y estimados. Como puede observarse en la figura, los valores estimados de $K c$ son más cercanos a los valores reales de $K c$. La diferencia entre los valores propuestos por FAO-56 y los valores reales de $K c$ es debido al hecho de que los 
coeficientes de cultivo de la FAO se obtuvieron para unas condiciones agroclimáticas específicas, que son diferentes de las condiciones existentes en el área de estudio. Esto revela la necesidad de ajustar los valores de $K c$ a las condiciones agroclimáticas de la zona de cultivo.

El método fue validado durante los dos años siguientes en el mismo cultivo de lechuga y en condiciones climáticas similares. Para este propósito, la fase de validación descrita en la Sección 2.2 se realizó en ambos años.

La primera validación se llevó a cabo durante un período de 109 días a partir de octubre de 2010 hasta febrero de 2011. Durante este período de validación, se realizaron dos comparaciones. En primer lugar, se analizó la relación entre la altura de la planta estimada y la altura medida, obteniéndose un buen ajuste (Fig. 1.11c). También se llevó a cabo un análisis de regresión lineal, obteniéndose un coeficiente de correlación de 0,994 y una pendiente de la recta de regresión lineal de 1,072. En este caso, el valor obtenido de RMSE fue 1,197 (Tabla 1.1). Al igual que en la fase de modelado, la altura de la planta fue sobrestimada, en este caso a partir del día 67 hasta el día 97. En segundo lugar, se compararon los valores reales y estimados de $K c$, y se observó un notable acuerdo entre los datos medidos y los valores estimados de $K c$ a lo largo del ciclo de crecimiento (Fig. 1.11d). Esta comparación también fue acompañada por un análisis de regresión lineal, obteniéndose un coeficiente de correlación de 0,976 y una pendiente de la recta de regresión lineal de 0,921 (Tabla 1.1). En este caso, se obtuvo un RMSE de 0,032. Los valores de $K c$ obtenidos a partir del modelo logarítmico se comportaron de manera más estable que los valores de $K c$ obtenidos a partir de la relación de Bowen (Fig. 1.11d). Esta situación puede haber surgido debido a que el modelo no cubre variaciones periódicas temporales, que son detectadas por la estación Bowen.

La segunda validación se llevó a cabo durante un período de 107 días a partir de octubre de 2011 hasta enero de 2012. La Fig. 1.11e compara la altura medida de la planta y la altura de la planta estimada, obteniéndose un coeficiente de correlación de 0,990, una pendiente de la recta de regresión lineal de 0,884 y un RMSE de 1,362 (Tabla 1.1). En este caso, la altura de la planta fue subestimada desde el día 55 hasta el día 109. Esta subestimación puede ser debida a que el valor medido de $P G C$ fue mayor que el valor estimado por la ecuación (Ec. 5). Finalmente, la Fig. 1.11f presenta la relación entre los valores reales y estimados de $K c$, obteniendo una pendiente de la recta de regresión lineal de 1,045, un coeficiente de correlación de 0,978 y un RMSE de 0,029 (Tabla 1.1). Como 
en la primera fase de validación, el modelo logarítmico también se comportó de una manera más estable que los valores de $K c$ obtenidos a partir de la estación Bowen (Fig. $1.11 f)$.

Tabla 1.1. Datos estadísticos del análisis de regresión lineal llevado a cabo al comparar los valores reales y estimados de altura de la planta y valores reales y estimados del coeficiente de cultivo $K c$ durante las fases de modelado y validación.

\begin{tabular}{clllcccc}
\hline $\begin{array}{c}\mathrm{N} \\
\text { Figura }\end{array}$ & Fase & Parámetro X & Parámetro Y & Pendiente & Intersección & R $^{2}$ & RMSE $^{\text {Tamaño }}$ \\
\hline muestra
\end{tabular}

\section{DISCUSIÓN}

Algunos estudios realizados en otros cultivos, como tomate (Hanson y May, 2005), fríjol (De Medeiros et al., 2001) y cebolla (López-Urrea et al., 2009), establecieron una relación directa entre el porcentaje de cobertura del suelo y el coeficiente de cultivo $K c$. No obstante, estudios realizados en cultivos de lechuga obtuvieron malas estimaciones (Allen y Pereira, 2009; Grattan et al., 1998).

Para tomate, Hanson y May (2005) fueron capaces de definir una ecuación polinómica de segundo orden que describe la relación entre la cobertura del dosel $(C C$, en $\%)$ y el coeficiente único de cultivo $(K c)$ :

$$
K c=0,126+0,0172 C C-0,0000776 C C^{2}
$$

El análisis de regresión realizado por los autores fue altamente significativo, obteniéndose un coeficiente de correlación de 0,96 y un valor P menor que 0,0001 , lo que indica que la ecuación describe razonablemente la relación entre el coeficiente de cultivo y la cobertura del dosel en tomate bajo diversas condiciones específicas.

Para frijol, De Medeiros et al. (2001) relacionaron satisfactoriamente el coeficiente basal de cultivo $K c b$ con $P G C$, demostrando su fuerte dependencia del tamaño del dosel mediante la siguiente ecuación:

$$
K c b=0,320+3,0 \times 10^{-4} P G C+5,5 \times 10^{-4} P G C^{2}-2,5 \times 10^{-6} P G C^{3}
$$

Los autores obtuvieron una fuerte relación entre el parámetro $K c b$ y el desarrollo del dosel, obteniendo un coeficiente de correlación de 0,97 y un valor P inferior a 0,01 . 
Para cebolla, López-Urrea et al. (2009) observaron una relación lineal entre los valores de $K c$ y $K c b$ obtenidos a partir de mediciones lisimétricas y $P G C$ :

$$
K c=0,811 P G C+0,597 ; \quad K c b=0,7792 P G C+0,5261
$$

El análisis de regresión lineal realizado por los autores arrojó coeficientes de correlación de 0,922 para $K c$ y 0,911 para $K c b$, lo que demuestra la fuerte dependencia lineal de los parámetros $K c$ y $K c b$ con $P G C$ en cultivos de cebolla.

Además de los estudios mencionados anteriormente, otro importante trabajo llevado a cabo por Grattan et al. (1998) intentó establecer una relación directa entre el porcentaje de cobertura del suelo y el coeficiente de cultivo $K c$ para siete cultivos hortícolas en California, EE.UU. Los autores midieron los valores de $K c$ utilizando sistemas de relación de Bowen, garantizando así la exactitud de los datos. En el estudio, los autores afirmaron que los coeficientes de cultivo cambian como una función cuadrática del porcentaje de cobertura del suelo para la mayoría de los cultivos que alcanzan cobertura total (100\% cobertura del suelo). Los autores utilizaron expresiones cuadráticas para ajustar los datos a partir de los siete cultivos y obtuvieron coeficientes de correlación de 0,60 para alcachofa, 0,69 para haba, 0,74 para brócoli, 0,63 para lechuga, 0,90 para melón, 0,72 para cebolla y 0,87 para fresa.

Para lechuga, la ecuación polinómica propuesta por los autores es la siguiente:

$$
K c=-0,00003 P G C^{2}+0,012 P G C+0,083
$$

Esta ecuación obtiene un coeficiente de correlación de sólo 0,63, lo que demuestra que no se puede establecer una relación directa entre el porcentaje de cobertura del suelo y el coeficiente de cultivo $K c$ para cultivos de lechuga. Este caso también es confirmado por el estudio realizado por Allen y Pereira (2009), que obtienen resultados similares después de cálculos complejos que requieren medir no sólo la fracción de suelo cubierto o bajo la sombra de la vegetación, sino también la altura de la vegetación y la cantidad de regulación estomática en condiciones de suelo húmedo.

En este caso, una solución es determinar una relación indirecta entre la evapotranspiración y el porcentaje de cobertura del suelo para cultivos de lechuga. El método propuesto en este trabajo estima primero la altura de la planta utilizando el valor de $P G C$ y luego calcula el coeficiente de cultivo $K c$ basado en el término $P G C / h$. Los resultados demuestran la validez del método en cultivos de lechuga, obteniéndose 
coeficientes de correlación muy cercanos a la unidad y bajos valores de RMSE para cada correlación (Tabla 1.1).

Aunque el método propuesto sólo ha sido validado para cultivos de lechuga, los prometedores resultados obtenidos aquí representan una base para la aplicación potencial del método propuesto en otros cultivos hortícolas, tales como colinabo y melón.

\section{CONCLUSIONES}

El artículo presenta un nuevo método basado en visión computacional para estimar el coeficiente de cultivo $K c$ de cultivos de lechuga sobre la base de fotografías digitales de la cubierta vegetal. Para este cálculo, primero se estima la altura de la planta $h$ a partir del parámetro $P G C$; a continuación, el término $P G C / h$ se correlaciona con el coeficiente de cultivo $K c$. Esto permite obtener dos ecuaciones matemáticas con las que modelar las relaciones entre estos parámetros; se obtuvieron coeficientes de correlación de 0,993 y 0,979 cuando se estimó $h$ a partir de $P G C$ y cuando se calculó $K c$ a partir del término $P G C / h$, respectivamente, lo que demuestra la validez del método.

Los resultados proporcionados por estas ecuaciones fueron validados durante tres campañas agrícolas (octubre 2009 - febrero 2010, octubre 2010 - febrero 2011 y octubre 2011 - enero 2012), obteniéndose coeficientes de correlación de 0,990, 0,994 y 0,990 (respectivamente) al comparar valores reales y estimados de altura de la planta, y de 0,977, 0,976 y 0,978 (respectivamente) cuando se compararon valores reales y estimados de $K c$; por tanto, este método funcionó mejor que trabajos anteriores encontrados en la literatura.

Los valores reales y estimados de $K c$ obtenidos mediante este método también fueron compararon con los valores propuestos por FAO-56 (Allen et al., 1998) para cultivo de lechuga en un clima Mediterráneo. Los resultados demostraron que los coeficientes de cultivo de la FAO fueron obtenidos para unas condiciones agroclimáticas específicas, diferentes a las condiciones existentes en el área de estudio. Esto revela la necesidad de ajustar los valores de $K c$ a las condiciones agroclimáticas de la zona de cultivo. En contraste, la metodología propuesta permite obtener coeficientes de cultivos ajustados a las condiciones climáticas y etapas de desarrollo dadas. 

Special Issue: Image Analysis in Agriculture

\title{
Research Paper
}

\section{A digital image-processing-based method for determining the crop coefficient of lettuce crops in the southeast of Spain ${ }^{\star}$}

\author{
Daniel G. Fernández-Pacheco ${ }^{a, *}$, David Escarabajal-Henarejos ${ }^{b}$, \\ Antonio Ruiz-Canales ${ }^{c}$, Julián Conesa ${ }^{a}$, Jose M. Molina-Martínez ${ }^{b}$ \\ ${ }^{a}$ Graphical Expression Department, Universidad Politécnica de Cartagena, Cartagena 30202, Spain \\ ${ }^{\mathrm{b}}$ Food Engineering and Agricultural Equipment Department, Universidad Politécnica de Cartagena, \\ Cartagena 30203, Spain \\ ${ }^{\mathrm{C}}$ Engineering Department, Miguel Hernández University of Elche, Orihuela 03312, Spain
}

\section{A R T I C L E I N F O}

Article history:

Received 30 November 2012

Received in revised form

26 July 2013

Accepted 27 July 2013

\begin{abstract}
In the arid and semi-arid regions of the southeast of Spain, the low availability of water for irrigation requires the development of new water-conserving irrigation techniques. This leads to the use of precision agriculture technologies that permit an improvement in performance or reductions in the consumption of water and fertilisers. In this context, the use of digital photography enables plant growth monitoring, which allows crop water requirements to be determined from variables that are directly related to evapotranspiration. One of these variables is the percentage of ground cover, which has also been correlated with plant height. This paper presents a new method based on computer vision for estimating the crop coefficient $\left(K_{c}\right)$ of lettuce crops from the percentage of ground cover (PGC) extracted from digital photographs. In contrast to other methods reported in the literature, plant height $(h)$ is estimated first; then, the term PGC/h is correlated with $K_{\mathrm{c}}$. The method was successfully applied to and validated using a commercial crop of lettuce (Lactuca sativa L. cv. 'Hierro') located in the southeast of Spain.
\end{abstract}

(C) 2013 IAgrE. Published by Elsevier Ltd. All rights reserved.

\section{Introduction}

In the current economic context, the aim of a farm is to obtain the maximum benefits in a social and economic environment. This means on the one hand a more rational use of environmental resources (soil-water-climate) and on the other hand the use of irrigation technologies (Goncalves, Muga, Horst, \& Pereira, 2011; Oron, DeMalach, Gillerman, David, \& Lurie, 2002) and appropriate cultivation techniques. In the southeast of Spain, due to the region's semiarid climate, a widespread shortage of water for agriculture has created a strong need for strategies to improve water use

\footnotetext{
Developed from a presentation at the IV International Workshop on Computer Image Analysis in Agriculture, held at CIGR-AgEng 2012, Valencia, Spain: July 8the12th, 2012.

* Corresponding author. Dpto. Expresión Gráfica, Universidad Politécnica de Cartagena, Campus Muralla del Mar, C/ Doctor Fleming s/n, 30202 Cartagena, Spain. Tel.: +34968 3264 84; fax: +34 968326474

E-mail address: eagledang@gmail.com (D.G. Fernández-Pacheco).

1537-5110/\$ - see front matter () 2013 IAgrE. Published by Elsevier Ltd. All rights reserved.

http://dx.doi.org/10.1016/j.biosystemseng.2013.07.014
} 


\begin{tabular}{|c|c|}
\hline \multicolumn{2}{|c|}{ Nomenclature } \\
\hline$a, b, c, d$ & coefficients \\
\hline BREB & Bowen ratio-energy balance \\
\hline CC & canopy coverage (\%) \\
\hline $\mathrm{ET}_{\mathrm{c}}$ & evapotranspiration \\
\hline $\mathrm{ET}_{\text {。 }}$ & reference evapotranspiration \\
\hline G & soil heat flux \\
\hline$h$ & plant height \\
\hline $\mathrm{H}$ & sensible heat flux \\
\hline$K_{\mathrm{c}}$ & crop coefficient \\
\hline$K_{\mathrm{cb}}$ & basal crop coefficient \\
\hline LAI & leaf area index \\
\hline
\end{tabular}

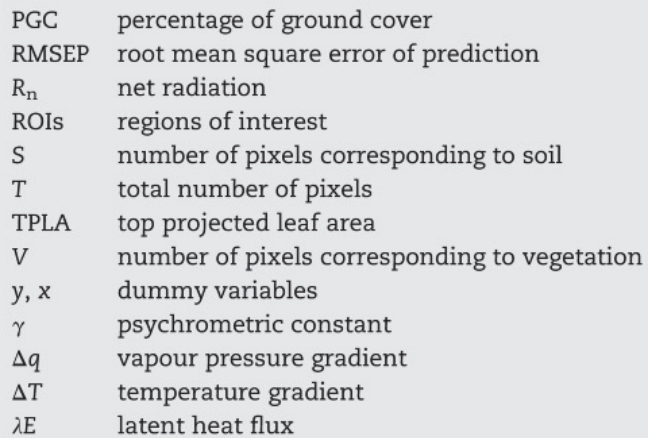

efficiency (Molina-Martínez, Jiménez, Ruiz-Canales, \& Fernández-Pacheco, 2011).

In this context, precision agriculture has been shown to be a solution for water use improvement in production systems, among others. Due to lower material costs and the development of new remote sensing systems (Ahamed et al., 2012; Xiang \& Tian, 2011), it has been possible to apply digital image-processing techniques to agriculture (Lorente et al., 2012).

Regarding efficient water management, the use of digital photography in precision agriculture permits the monitoring of plant growth, thus allowing crop water requirements to be determined based on variables that are directly related to evapotranspiration $\left(\mathrm{ET}_{\mathrm{c}}\right)$, which is calculated by multiplying the crop coefficient $\left(K_{c}\right)$ and the reference evapotranspiration (ETo) (Allen, Pereira, Raes, \& Smith, 1998).

One such variable is the leaf area index (LAI), which predicts photosynthetic primary production and is used as a reference tool for crop growth (Fortin, Parent, Anctil, \& Bolinder, 2008). As such, LAI plays an essential role in theoretical production ecology. Because all direct methods of measuring LAI are similar in that they are extremely labourintensive, destructive and costly in terms of time and money, other methods of measuring LAI that involve indirect and less time-consuming procedures have been developed (Kirk, Andersen, Thomsen, Jorgensen, \& Jorgensen, 2009). For example, Lu, Lu, Wei, and Chan (2004) proposed several models for estimating the area of a taro leaf using nondestructive measurements of length and width, and Campillo, Garcia, Daza, and Prieto (2010) developed an inexpensive and simple method for estimating LAI in vegetable crops using the percentage of ground cover extracted from digital images. This relationship between leaf area index and ground cover has also been demonstrated in potato by Boyd, Gordon, and Martin (2002), who obtained a highly (linear) correlation even under extreme levels of competition and different types of management.

Another variable directly related to the concept of evapotranspiration is the percentage of ground cover (PGC), although some authors also use the term 'top projected leaf area' (TPLA) to indicate the horizontal projection (equivalent to the shadow) when viewed from a position directly overhead. This parameter is usually extracted from digital images using image-processing techniques, which provide demonstrably accurate results (Congling, Guanghui, \& Changying, 2005).

In recent studies, a strong relationship has been revealed between top projected leaf area and other parameters in horticultural crops. For example, Giacomelli, Ling, and Kole (1998) and Giacomelli, Ling, and Morden (1996) were able to determine nutrient stress in lettuce plants using a machine vision system that extracted the TPLA of lettuce seedlings; Ling and Ruzhitsky (1992) found strong correlations between fresh weight, dry weight and TPLA measured using image-processing technology in tomato seedlings; Blasco, Aleixos, Roger, Rabatel, and Molto (2002) developed a robotic system based on image analysis to eliminate weeds in lettuce fields based on the size of the projected area; and Story, Kacira, Kubota, Akoglu, and An (2010) designed a machine vision system to detect calcium deficiency in lettuce crops grown under greenhouse conditions using temporal, colour and morphological changes in the plant, such as TPLA.

Additionally, percentage of ground cover has also been correlated with plant height, providing successful results in ornamental shrubs (Grant, Davies, Longbottom, \& HarrisonMurray, 2012), winter wheat (Xu, Wang, Li, Song, \& Huang, 2010) and constructed wetland plants (Xiao, Tingfangzi, Suiliang, \& Yang, 2011), among others. Because plant height is directly related to crop developmental stage, a direct relationship between the crop coefficient $K_{\mathrm{c}}$ and the percentage of ground cover has been studied for various irrigation systems, and successful results have been obtained in tomatoes (Hanson \& May, 2005), beans (De Medeiros, Arruda, Sakai, \& Fujiwara, 2001) and onions (Lopez-Urrea, Olalla, Montoro, \& Lopez-Fuster, 2009). However, studies carried out in lettuce crops reported poor estimations (Allen \& Pereira, 2009; Grattan et al., 1998).

In this paper, a new and simple method based on digital image processing for estimating the crop coefficient in lettuce crops from digital photographs of the vegetation cover is proposed. In contrast to other methods that have been proposed in the literature, PGC is calculated first and used to estimate plant height $(h)$; then, the term PGC/ $h$ is correlated with the crop coefficient $K_{\mathrm{c}}$. This method was applied and validated on a commercial crop of lettuce (Lactuca sativa L. cv. 'Hierro') located in the southeast of Spain, and successful results were obtained. 


\section{Materials and methods}

The method proposed aims to calculate the crop coefficient $K_{c}$ in lettuce crops based on a sequence of digital photographs of the vegetation cover. The value of $K_{\mathrm{c}}$ can be used to estimate the water requirements of the analysed crop with reasonable accuracy and be introduced in an irrigation scheduling system.

The method consists of three well differentiated phases (see Fig. 1): i) a first phase (or 'modelling phase') in which the mathematical equations that correlate the percentage of ground cover (extracted from digital images), the plant height (measured in the field) and the crop coefficient $K_{c}$ (obtained from the data provided by a Bowen ratio station) along the crop development stages are developed, ii) a second phase (or 'validation phase') in which the equations are validated by contrasting the estimated and measured values for the plant height and the crop coefficient $K_{\mathrm{c}}$, and iii) a third phase (or 'application phase') in which the equations are directly used to estimate the coefficient $\mathrm{K}_{\mathrm{c}}$ based on digital crop images.
Once the modelling phase has been executed and the mathematical equations have been extracted, the application phase can be directly accomplished. However, we recommend that the validation be performed after a determined number of cropping seasons to verify the quality of the estimations and adjust the equations if it proves necessary.

To accomplish the three phases, several steps are required (see Fig. 1). In the following paragraphs, the experimental plot is described; immediately following, the methodology is described in more detail.

\subsection{Experimental plot}

The method was studied during a period of 97 days from October 2009 to February 2010 on a commercial crop of lettuce (L. sativa L. cv. 'Hierro') located in Fuente Álamo (latitude $37^{\circ} 42^{\prime} 35^{\prime \prime} \mathrm{N}$, longitude $1^{\circ} 10^{\prime} 20^{\prime \prime} \mathrm{W}$ and altitude $125 \mathrm{~m}$ ) in the province of Murcia, Spain. The plot has an approximate area of $6.5 \mathrm{ha}$, and the plants were placed between rows spaced at $50 \mathrm{~cm}$ that were oriented north-south; the plants were

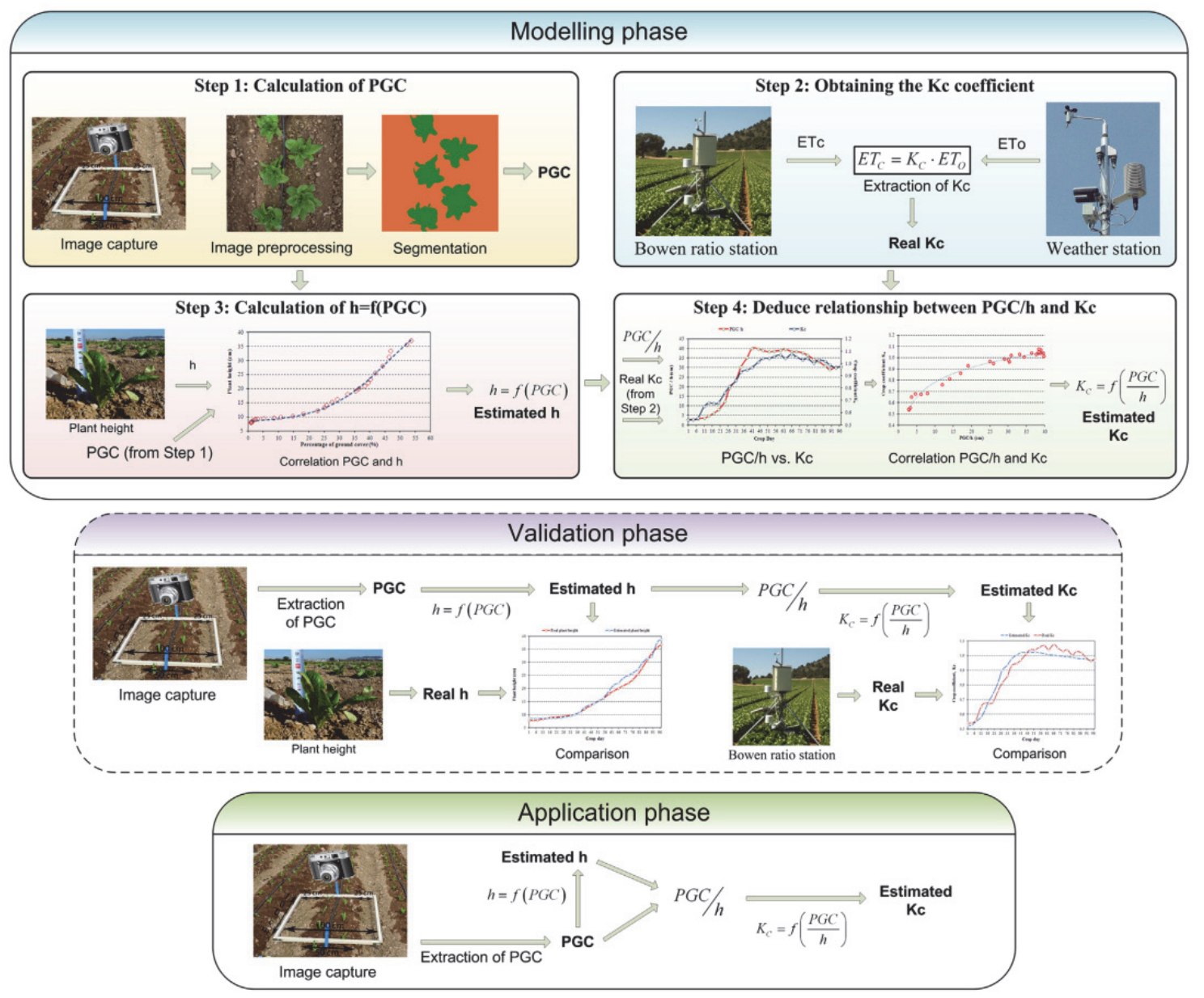

Fig. 1 - Scheme of the proposed methodology illustrating the various phases and processes. 
arranged in staggered rows with a plantation density of 5 plants $\mathrm{m}^{-2}$. The plot was equipped with drip irrigation laterals of $16 \mathrm{~mm}$ and emitters of $4 \mathrm{l} \mathrm{h}^{-1}$ spaced $0.60 \mathrm{~m}$ apart. The soil is classified as a Calcixeroll and comprises lime carbonate materials with a loamy texture.

The climate of the zone is Mediterranean subdesert and experiences mild temperatures in winter $\left(10-12{ }^{\circ} \mathrm{C}\right)$ and a hot summer $\left(24-27^{\circ} \mathrm{C}\right)$. The mean annual temperature is approximately $17.5^{\circ} \mathrm{C}$. These temperatures make frost and snow unlikely. Rainfall is irregularly distributed and occurs predominantly between autumn and spring. Precipitation levels were recorded using a RAIN-O-MATIC (Campbell Scientific, Logan, UT, USA) pluviometer, which is included in a weather station placed inside the experimental plot. In the period when the first modelling phase was accomplished, no rainfall was present on $79 \%$ of the days. On the other days, rainfall levels of $0.5-9.0 \mathrm{~mm}^{-1 a y}{ }^{-1}$ (grouped in intervals of 2-3 days) were recorded. The mean precipitation value was exceeded only on three days, reaching values of $22.6 \mathrm{~mm} \mathrm{day}^{-1}$. During the modelling phase, the total rainfall amount did not exceed $70 \mathrm{~mm}$. The distribution and intensity patterns were very similar during the validation phases and reached a maximum of $85 \mathrm{~mm}$ in each period.

\subsection{Modelling phase}

2.2.1. Calculation of the percentage of ground cover

The modelling phase starts with the calculation of the percentage of ground covered by the plants, and this is the main input of the method proposed in the paper.

Because the experimental parcel can be divided into equal subparcels of $1 \mathrm{~m} \times 1 \mathrm{~m}$ (see the inset in Fig. 2), digital photographs of the vegetation coverage were taken over 4 sample subparcels of $1 \mathrm{~m}^{2}$, which were randomly chosen as representative of the planted land (see Fig. 2); the edge of the plantation was avoided to remove the edge effect. The subparcels were conveniently marked using pickets placed in the central part of the balk, which were later used as references to place the midpoints of a $1 \mathrm{~m} \times 1 \mathrm{~m}$ frame (see the detail in Fig. 2). Photographs were taken from the first day of the

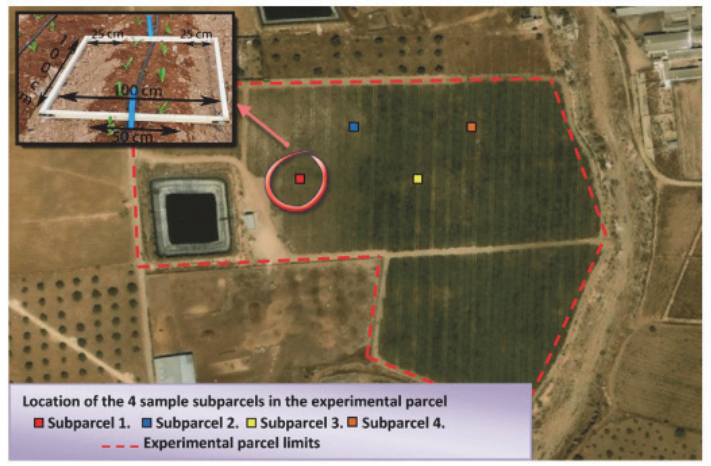

Fig. 2 - Location of the four sample subparcels in the experimental plot and an example of the $1 \mathrm{~m} \times 1 \mathrm{~m}$ frame used while taking the images. transplantation and for each sample subparcel at intervals of $2-3$ days, providing 116 images.

Photographs were taken vertically over the crop at a fixed height of $1.40 \mathrm{~m}$ above ground level using a digital camera (Lumix DMC-LX3, Panasonic, Japan) equipped with a chargecoupled device (CCD) sensor (resolution, 10.1 megapixels focal length, $24 \mathrm{~mm}$ ) that was mounted on a tripod. To match up the percentage of the ground covered by vegetation and the fraction of the area shaded by the plant, photographs were always taken at solar noon. It is recommended to take several photographs of each subparcel and to select the best shot (i.e., a photograph that does not show luminosity defects or concavity and is correctly framed) later.

After recording photographs of the four sample subparcels and selecting the best shots, the images were digitally preprocessed such that only the interior of the frame was left (see Fig. 3). For this purpose any commercially available photo editing software can be used. Because the method proposed here calculates the ground cover as a percentage (rather than the number of pixels), the final resolution of the image will not affect the results; the method is therefore scale-invariant. In other words, because the percentage divides the number of vegetation pixels by the total number of pixels in the image, this proportion will remain the same if the image is scaled.

The preprocessed images were later processed using ENVI ${ }^{\circledast}$ (Environment for Visualizing Images) software (Research System Inc., Boulder, CO, USA), which provides an easy to use environment to display and analyse images of any size and type of data.

The first phase was segmentation of the image to discriminate between soil (beige) and vegetation (green). The software permitted defining these two classes and selecting regions of interest (ROIs) in the image that pertained to the same class (Fig. 3). Once these ROIs were defined, the image was segmented using a maximum likelihood supervised classification of the image based on the defined ROIs (Fig. 3). After segmentation, the number of pixels corresponding to vegetation (V), soil (S) and totality $(T)$ of the image were obtained and used to calculate the percentage of ground cover as the $\mathrm{V} / \mathrm{T}$ ratio.

Once the percentage of ground cover was obtained for each subparcel, the average value of the 4 subparcels was calculated for each sample day (Fig. 4).

2.2.2. Obtaining the $\mathrm{K}_{\mathrm{c}}$ coefficient using a Bowen ratio station According to the Food and Agriculture Organization of the United Nations (FAO) methodology (Doorenbos \& Pruitt, 1977), the evapotranspiration of a given crop is directly related to the reference evapotranspiration by a crop coefficient, which reflects the relationship between the plant properties and its water requirements:

$\mathrm{ET}_{\mathrm{c}}=\mathrm{K}_{\mathrm{c}} \cdot \mathrm{ET}_{\mathrm{o}}$

This crop coefficient $K_{\mathrm{c}}$ is considered a 'global $\mathrm{K}_{\mathrm{c}}$ ' and also includes variations in the early developmental stages depending on local conditions, type of irrigation used, and crop grid, among others (Allen, Pereira, Howell, \& Jensen, 2011). These variations should be considered if the crop coefficient calculated using this methodology is applied to other lettuce crops. 


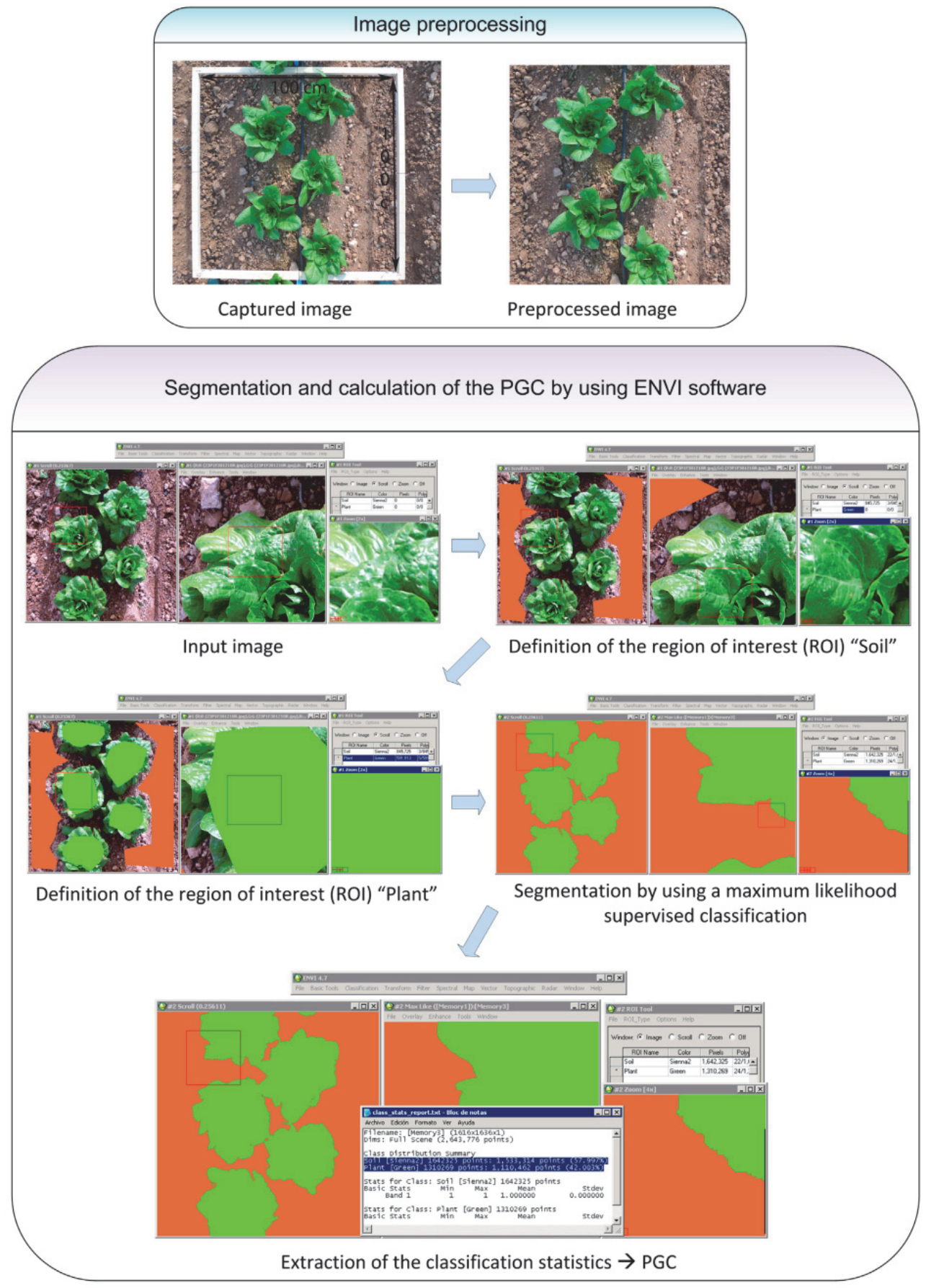

Fig. 3 - Preprocessing, segmentation and extraction of PGC.

For this study, the reference evapotranspiration $\left(\mathrm{ET}_{\mathrm{o}}\right)$ value was calculated by applying the FAO-56 Penman-Monteith equation (Allen et al., 1998) to the data obtained from a weather station placed inside the experimental plot. The evapotranspiration of the crop $\left(\mathrm{ET}_{\mathrm{c}}\right)$ was calculated by applying the Bowen ratio-energy balance (BREB) method. For this purpose, a Bowen ratio station was placed at the centre of the plot. The method is based on the energy balance, forcing 


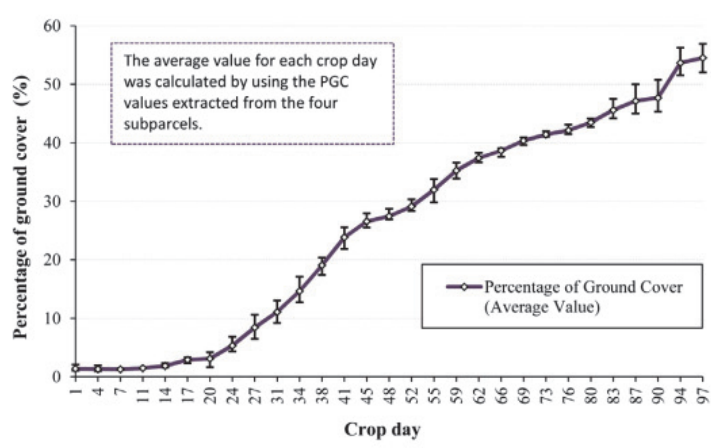

Fig. 4 - Average PGC and standard error for each crop day.

its closure by use of the $H / \lambda E$ ratio, known as the Bowen ratio (Bowen, 1926); this ratio provides information about the partition of the available energy at the surface between the sensible $(H)$ and latent $(\lambda E)$ heat fluxes. A reasonable approximation to the energy balance equation at the surface can be written in terms of flux densities as:

$R_{\mathrm{n}}-G=\lambda E+H$

where $R_{n}$ is the net radiation, and $G$ is the soil heat flux. $H$ and $\lambda E$ fluxes are estimated as a function of the Bowen ratio, which is calculated using the flux-gradients:

$\beta=\frac{H}{\lambda E}=\gamma \frac{\Delta T}{\Delta q}$

where $\gamma$ is the psychrometric constant and $\Delta T$ and $\Delta q$ are the temperature and vapour pressure gradients, respectively, measured between two levels within the adjusted boundary layer. This permits calculation of the energy balance term corresponding to crop evapotranspiration $(\lambda E)$ using the following equation:

$\lambda E=\frac{R_{\mathrm{n}}-\mathrm{G}}{1+\beta}$

The Bowen ratio station used during this study was equipped with a net radiometer Model NR-LITE (Campbell Sci. Inst., USA) placed at $2 \mathrm{~m}$ above ground level. Both gradients were evaluated using sensors located on two arms, which were installed in the same direction as the row of plants and separated $45 \mathrm{~cm}$ from each other. The lower arm was placed $50 \mathrm{~cm}$ above the upper part of the vegetation. The temperature gradient was measured using two E-type fine-wire thermocouples (chrome-constantan) Model ASPTC (Campbell Sci. Inst., USA), and the vapour pressure gradient was obtained using a dew point mirror hygrometer Model Almemo-FHA64DTC1 (Ahlborn Mess, und R., Germany). The station was also endowed with a datalogger Model CR1000 (Campbell Sci. Inst., USA), which registered the variables required for use of the BREB method. Data obtained from the Bowen ratio station were also subjected to quality controls designed by Ohmura (1982) to ensure data quality.

Taking all of the above points into consideration, the $K_{\mathrm{c}}$ coefficient was calculated for each sample day using Eq. (1)

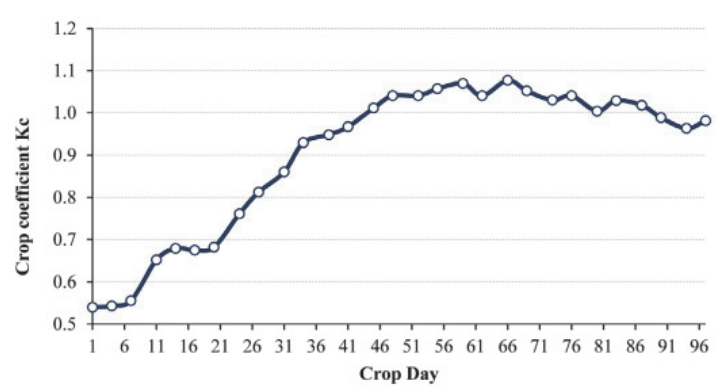

Fig. 5 - The crop coefficient calculated from the values provided by the stations.

and the $\mathrm{ET}_{\mathrm{o}}$ and $\mathrm{ET}_{\mathrm{c}}$ values obtained from the respective stations (Fig. 5).

\subsubsection{Estimation of plant height}

Each day, while photographs of the subparcels were taken, the heights of all plants included in each subparcel were measured to determine a possible relationship between plant height and the percentage of ground cover. The mean value for each subparcel was later calculated, as was the average value for all subparcels (Fig. 6).

The average values of the percentage of ground cover and plant height for each sample day show similar distributions (Fig. 7a). This led to the establishment of a relationship between the parameters; this relationship was then described by a function (Fig. 7b). This function permitted the estimation of plant height based on the percentage of ground cover extracted from the digital image of one subparcel. For the presented study, several approximation functions were analysed, including double sigmoid, logistic, Gompertz and monomolecular functions. The double sigmoid function yielded the best results.

\subsubsection{Estimation of the crop coefficient $\mathrm{K}_{c}$}

The crop coefficient $K_{c}$ was estimated from the ratio PGC/h. These two parameters are shown in Fig. 8a, appreciating a similar distribution that was used to obtain a logarithmic function to relate the PGC/h parameter to the crop coefficient $\mathrm{K}_{\mathrm{c}}$ (Fig. 8b).

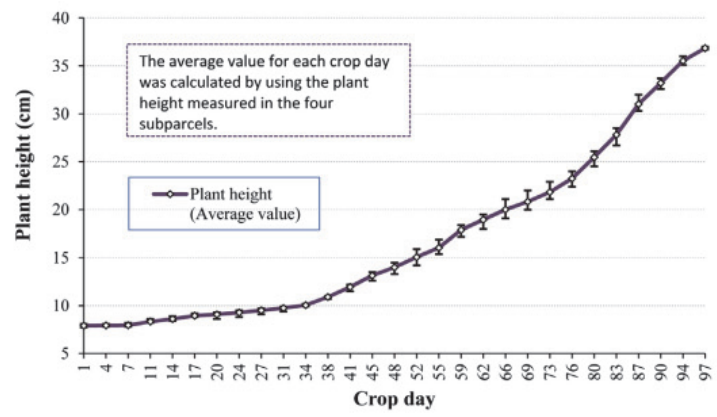

Fig. 6 - Average plant height and standard error for each crop day. 


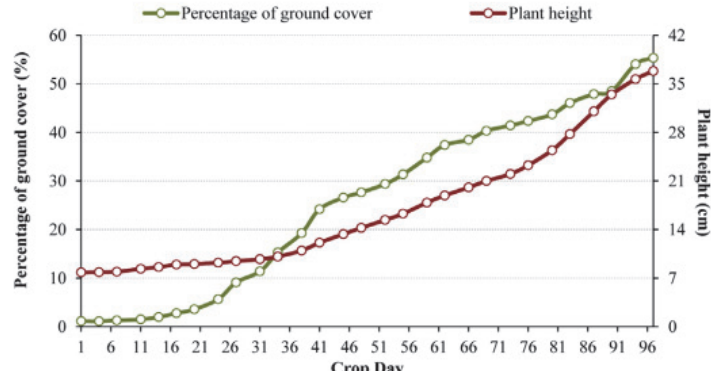

a)

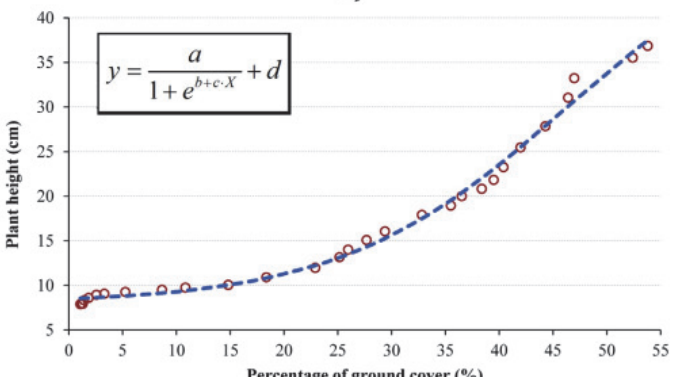

b)

Fig. 7 - a) Comparison of plant height and PGC. b) Correlation analysis.

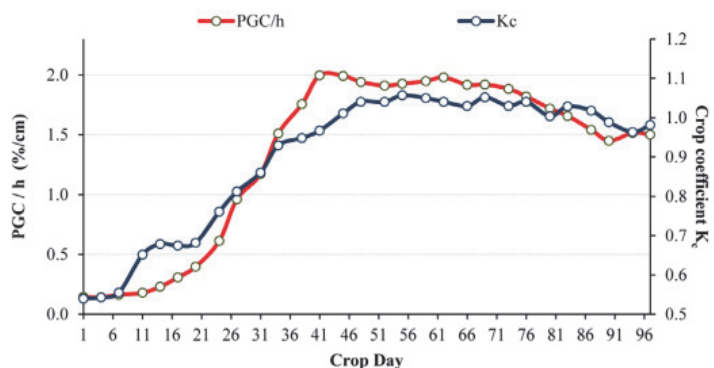

a)

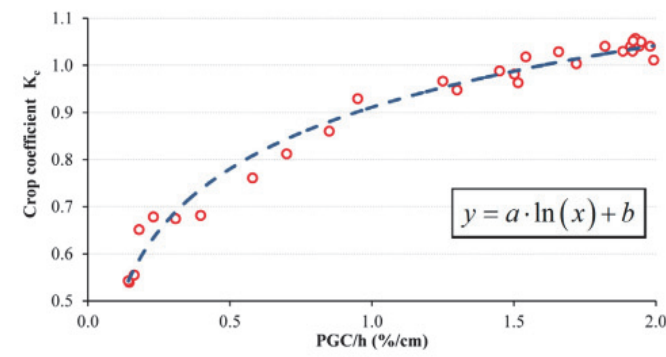

b)

Fig. 8 - a) Comparison of PGC/h and $K_{c}$. b) Correlation analysis.

\subsection{Validation phase}

Once the equations that relate PGC, $h$ and $K_{c}$ were obtained, they were validated during the following crop seasons.

During this validation phase, the following steps were performed:

i) Four new sample subparcels were selected and photographed, and the percentage of ground cover was obtained in the same manner as in the modelling phase.

ii) At the same time as photographs were taken, the plant heights were measured; the mean height of all plants in the four subparcels was calculated.

iii) Using the mean PGC value extracted from the four subparcels and the equation that was derived during the modelling phase, an estimate of plant height was obtained.

iv) The estimated plant height was compared with the measured height, and statistical data were obtained.

v) Using the PGC value divided by the estimated plant height and the second equation that was derived during the modelling phase, $K_{c}$ was estimated.

vi) Coincident with the taking of pictures and plant height measurement, $\mathrm{ET}_{\mathrm{C}}$ values were obtained from the Bowen ratio station and $\mathrm{ET}_{\mathrm{o}}$ values were obtained from the weather station to calculate the real $K_{\mathrm{c}}$ parameter.

vii) The estimate of $K_{c}$ was compared with the actual $K_{c}$, and statistical data were obtained.

The validation process was performed in the same parcel for which the equations were calculated because the value of $K_{c}$ is affected by several local conditions that can vary between crops.

The results of the validation process obtained during this study are provided in the following chapter.

\subsection{Application phase}

To provide the final user with a methodology for estimating the water requirements of lettuce crops, a direct application phase has been defined. This phase would be executed after the modelling phase for the following crop seasons. During this phase, the following processes would be executed:

i) One sample subparcel, which should be representative of all the cropped area, would be selected and photographed, and the percentage of ground cover is calculated in the same manner as during the modelling phase.

ii) Using the value of PGC extracted from the selected subparcel and the equation calculated during the modelling phase, an estimated plant height would be obtained.

iii) By dividing the PGC value by the estimated plant height and using the second equation derived during the modelling phase, an estimate of $K_{c}$ would be achieved.

These steps would allow the crop coefficient $K_{c}$ to be estimated for the studied lettuce crop using only a digital camera and image-processing techniques. 


\section{Results}

During the experiment, the modelling phase described in the previous chapter was performed first. In the first step, the percentage of ground cover was calculated using a digital camera and image-processing software. Figure 9 shows some results of the segmentation process for crop days 1, 27, 55 and 97. The calculated percentage of ground cover and the measured plant height are also indicated, showing the plant growth. It can be observed that the data acquisition process begins on the first day, corresponding with the phase during which the water requirements of the plant were small. The 27 th day coincides with an increase in water demand, indicating that this plant suffers due to the pre-nutrient enrichment phase. The 55th day corresponds with the phase of maximum water demand and coincides with the start of the maximum plant growth stage. Finally, the 97 th day represents the end of the season; at this time, the water demand decreases.

In the second step, the crop coefficient $K_{c}$ was obtained using Eq. (1), and data were obtained using a Bowen ratio station and a weather station, both located inside the experimental parcel. The crop coefficient $K_{\mathrm{c}}$ can be represented as a daily value or as a temporal average value, which is calculated for the various crop growth stages (Fig. 10). Using the criteria stated by Allen et al. (1998), the obtained values were classified into three periods according to the stage of crop evapotranspiration requirements: an initial phase with the minimum $K_{c}$ value, a middle phase in which the crop reaches the maximum evapotranspiration level, and a final phase with a final $K_{c}$ value that lies between the previous two values.

In the third step, an equation that correlates the percentage of ground cover obtained in the first step and the plant height was obtained. For this experiment, several approximation functions were analysed, including the double sigmoid, logistic, Gompertz and monomolecular functions. The best results were obtained using a double sigmoid function (Eq. (5)), where $y=h(\mathrm{~cm}), x=$ PGC (\%), $a=-43.42, b=-4.436$, $c=0.096$ and $d=51.421$. These values yielded a squared correlation coefficient of 0.993 .

$y=\frac{a}{1+e^{b+c \cdot x}}+d$

To evaluate the performance of the equation, the measured plant height and the plant height estimated using Eq. (5) were compared (Fig. 11a). A linear regression analysis was also carried out, yielding a slope of the linear regression line very similar to 1 (1.054) and a squared correlation coefficient of 0.990 (Table 1). The obtained root mean square error of prediction (RMSEP) was 1.293, demonstrating that the difference between the real values and the values predicted by the model was minimal. Plant height was overestimated from the 55 th to the 90th day (Fig. 11a). This overestimation may be because the measured PGC value was lower than the value expected by the equation (Eq. (5)). In this case, the obtained model did not consider that, during this stage, the PGC cannot take values greater than $30 \%$ during the 55 th day or greater than $49 \%$ during the 90 th day. Nevertheless, the error obtained did not exceed $10 \%$ in the worst case (during the $73 \mathrm{rd}$ day).

In the final step, the relationship between the parameter PGC/ $h$ and the crop coefficient $K_{c}$ permitted a logarithmic function that correlated them (Eq. (6)) to be obtained, where $y=K_{\mathrm{c}}, x=\mathrm{PGC} / \mathrm{h}(\% / \mathrm{cm}), a=0.189$ and $b=0.911$. These values yielded a squared correlation coefficient of 0.979 :

$y=a \cdot \ln (x)+b$

The $K_{\mathrm{c}}$ values estimated using this equation were compared with the actual $K_{c}$ values obtained in the second step (Fig. 11b); linear regression analysis was performed (Table 1), yielding a slope of the linear regression line very similar to 1 (0.966) and a squared correlation coefficient of 0.977 . The obtained value of RMSEP was 0.027 .

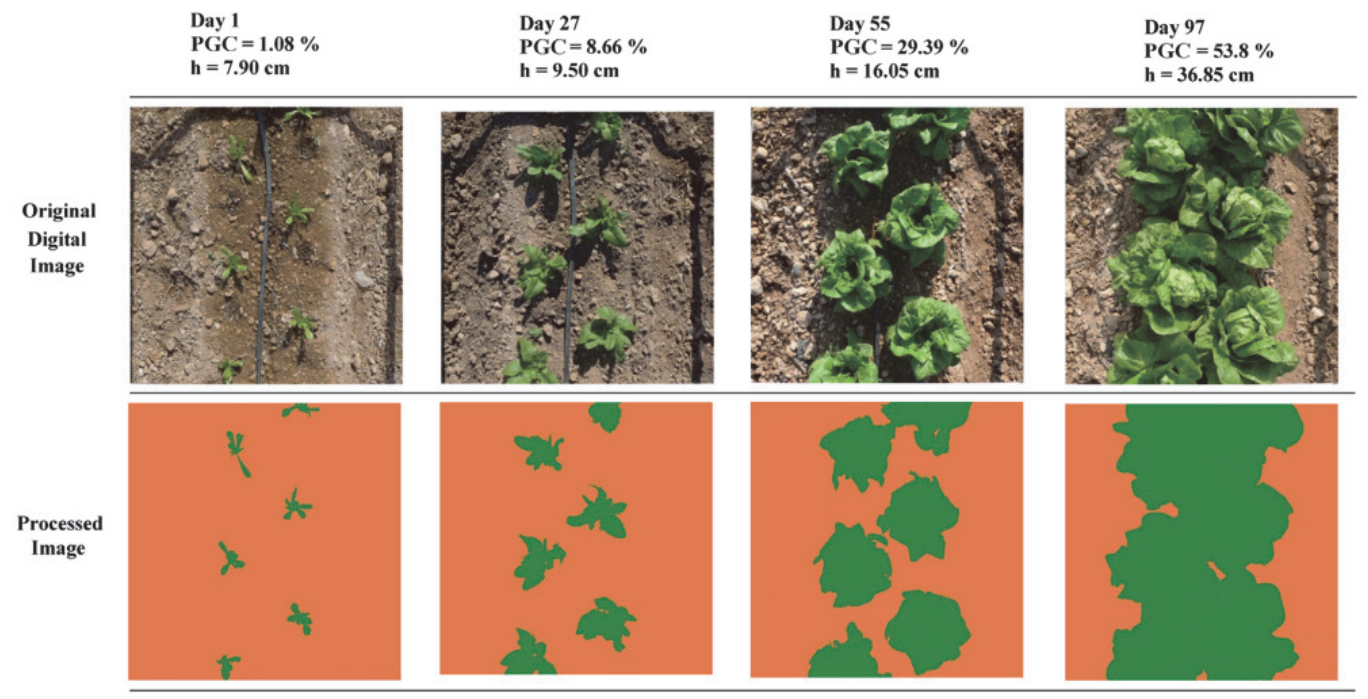

Fig. 9 - Example results obtained using the image-processing software. 


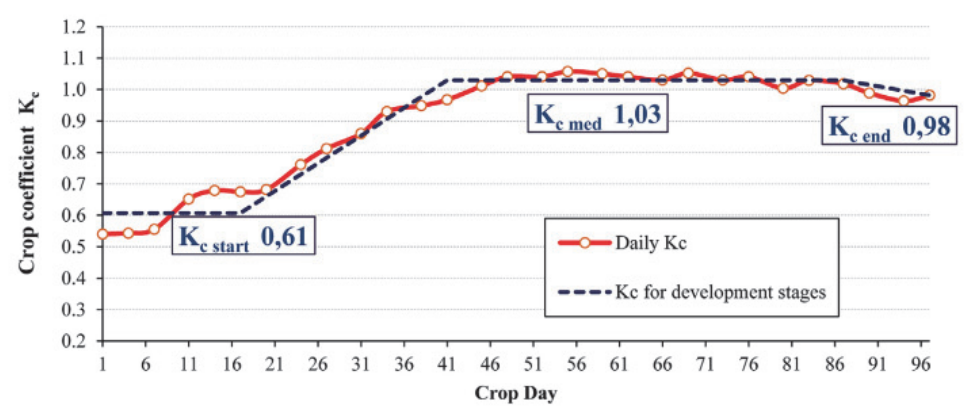

Fig. 10 - Daily and temporal average $K_{\mathrm{c}}$ values (modelling phase).

An additional comparison of the temporal averages of $K_{c}$ is shown in Fig. 12. In this figure, the average values proposed by FAO-56 (Allen et al., 1998) for lettuce crops in Mediterranean climates are compared with the average values of the estimated and real crop coefficients. As seen in the figure, the estimated $K_{c}$ values are the closest to the actual $K_{c}$ values. The difference between the values proposed by FAO-56 and the actual $K_{c}$ values is due to the fact

\section{Modelling Phase}

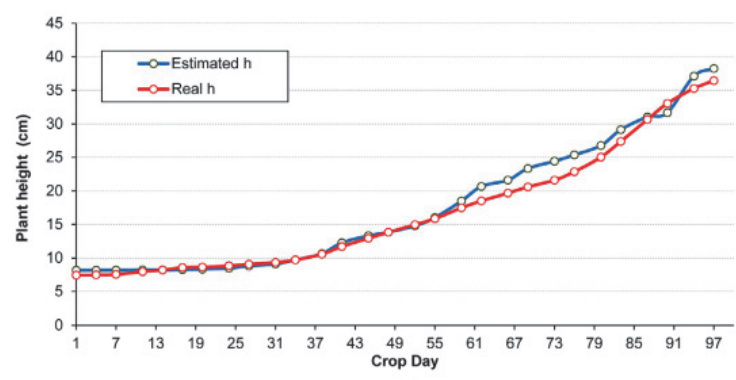

a)

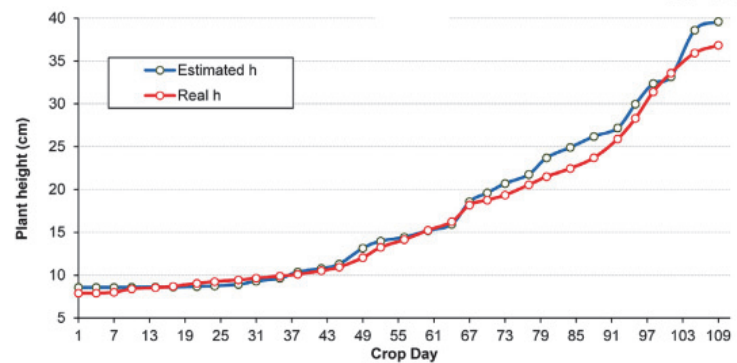

c)

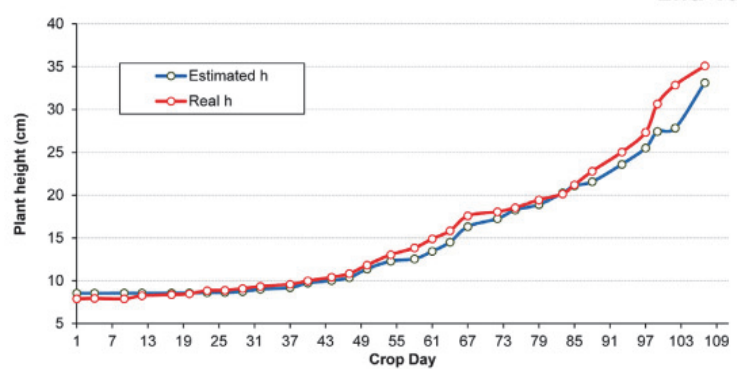

e)

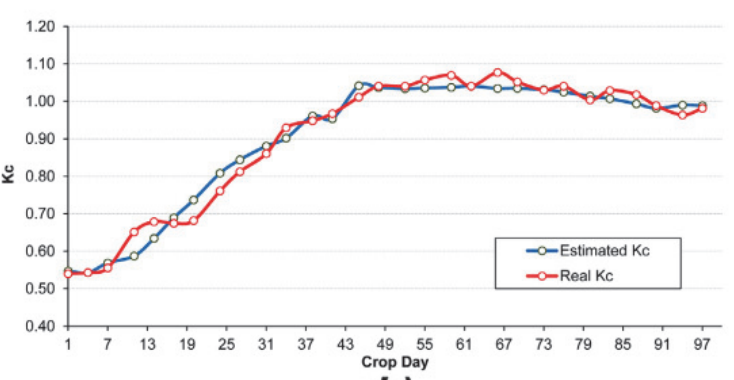

b)

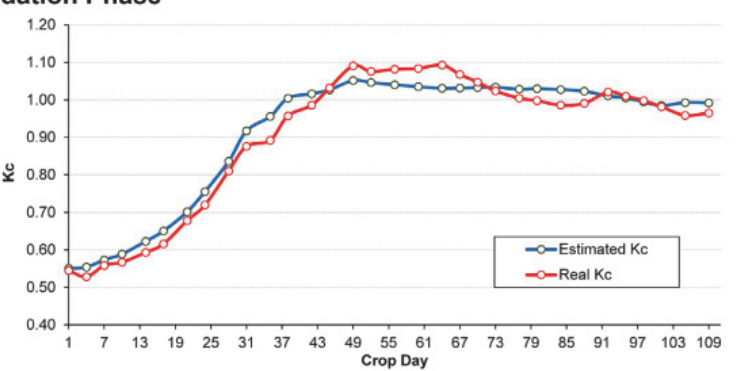

d)

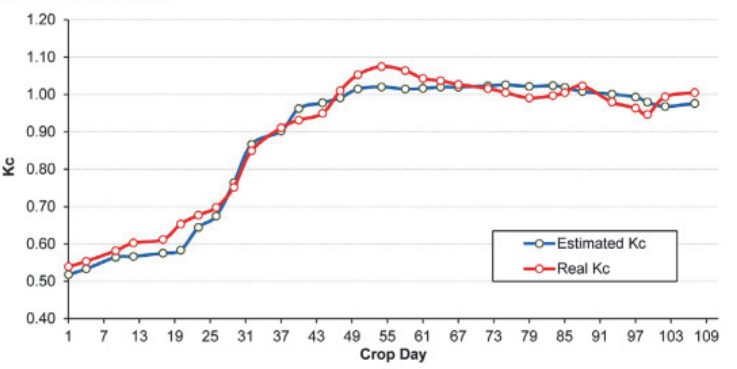

f)

Fig. 11 - Comparison of estimated and actual plant height and $\mathrm{K}_{\mathrm{c}}$ during the modelling and validation phases. 
Table 1 - Statistical data from the linear regression analysis performed when comparing estimated and actual plant height and $\mathrm{K}_{\mathrm{c}}$ during the modelling and validation phases.

\begin{tabular}{|c|c|c|c|c|c|c|c|c|}
\hline Figure number & Phase & $\mathrm{X}$ parameter & Y parameter & Slope & Interception & $R^{2}$ & RMSEP & $\begin{array}{c}\text { Sample } \\
\text { size }\end{array}$ \\
\hline $11 \mathrm{a}$ & Modelling & Real plant height & Estimated plant height & 1.054 & -0.18 & 0.990 & 1.293 & 29 \\
\hline $11 \mathrm{~b}$ & Modelling & Real crop coefficient & Estimated crop coefficient & 0.966 & 0.028 & 0.977 & 0.027 & 29 \\
\hline $11 \mathrm{c}$ & 1st Validation & Real plant height & Estimated plant height & 1.072 & -0.506 & 0.994 & 1.197 & 32 \\
\hline $11 \mathrm{~d}$ & 1st Validation & Real crop coefficient & Estimated crop coefficient & 0.921 & 0.081 & 0.976 & 0.032 & 32 \\
\hline $11 \mathrm{e}$ & 2nd Validation & Real plant height & Estimated plant height & 0.884 & 1.064 & 0.990 & 1.362 & 31 \\
\hline $11 \mathrm{f}$ & 2nd Validation & Real crop coefficient & Estimated crop coefficient & 1.045 & -0.049 & 0.978 & 0.029 & 31 \\
\hline
\end{tabular}

that the FAO crop coefficients were obtained for specific agroclimatic conditions, which are different from the conditions existing in the study area. This reveals the need to adjust the $K_{c}$ values to the agroclimatic conditions of the cultivation area.

The method was validated during the following two years on the same lettuce crop and under similar climatic conditions. For this purpose, the validation phase described in Section 2.2 was performed in both years.

The first validation was carried out during a period of 109 days from October 2010 to February 2011. During this validation period, two comparisons were undertaken. First, the relationship between the estimated plant height and the measured height was analysed, and a good fit was obtained (Fig. 11c). A linear regression analysis was also carried out, yielding a squared correlation coefficient of 0.994 and a slope of the linear regression line of 1.072. In this case, the obtained value of RMSEP was 1.197 (Table 1). Similar to the modelling phase, the plant height was overestimated in this case from the 67th to the 97th day. Second, the estimated and actual values of $K_{c}$ values were compared, and remarkable agreement was observed between the measured data and the modelled $K_{c}$ values throughout the growth cycle (Fig. 11d). This comparison was also accompanied by a linear regression analysis, which yielded a squared correlation coefficient of 0.976 and a slope of the linear regression line of 0.921 (Table 1 ). For this case, an RMSEP of 0.032 was obtained. The $K_{c}$ values obtained from the logarithmic model behaved in a more stable manner than the $K_{c}$ values obtained from the Bowen ratio (Fig. 11d). This situation may have arisen because the model does not cover temporal periodic variations, which are detected by the Bowen station.
The second validation was undertaken during the period of 107 days from October 2011 to January 2012. Figure 11e compares the measured plant height and the estimated plant height, yielding a squared correlation coefficient of 0.990 , a slope of the linear regression line of 0.884 and an RMSEP of 1.362 (Table 1). In this case, the plant height was underestimated from the 55 th to the 109th day. This underestimation may be because the measured PGC value was greater than the value predicted by the equation (Eq. (5)). Finally, Fig. $11 \mathrm{f}$ presents the relationship between the estimated $K_{\mathrm{c}}$ values and the actual values, yielding a slope of the linear regression line of 1.045, a squared correlation coefficient of 0.978 and an RMSEP of -0.029 (Table 1). As in the first validation phase, the logarithmic model also behaved in a more stable manner than the $K_{\mathrm{c}}$ values obtained from the Bowen ratio station (Fig. 11f).

\section{Discussion}

Some studies carried out on other crops, such as tomatoes (Hanson \& May, 2005), beans (De Medeiros et al., 2001) and onions (Lopez-Urrea et al., 2009), established a direct relationship between the percentage of ground cover and the crop coefficient $K_{\mathrm{c}}$. However, studies carried out on lettuce crops reported poor estimations (Allen \& Pereira, 2009; Grattan et al., 1998).

For tomatoes, Hanson and May (2005) were able to define a second-order polynomial equation that describes the relationship between canopy coverage (CC, in \%) and single crop coefficient $\left(K_{\mathrm{c}}\right)$ :

\section{$K_{c}=0.126+0.0172 C C-0.0000776 C^{2}$}

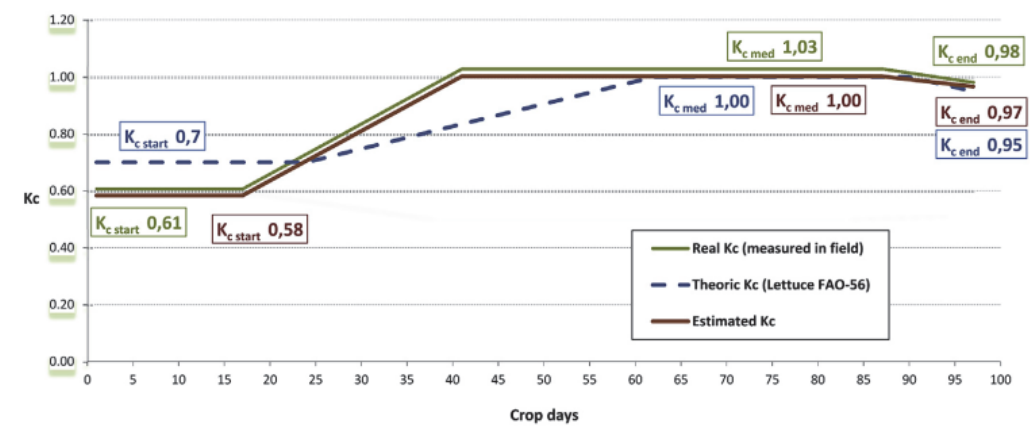

Fig. 12 - Comparison of different temporal average $K_{c}$ values (modelling phase). 
The regression analysis performed by the authors was highly significant, yielding a squared correlation coefficient of 0.96 and a P-value less than 0.0001 , indicating that the equation reasonably describes the relationship between the crop coefficient and canopy coverage in tomatoes under a variety of site-specific conditions.

For beans, De Medeiros et al. (2001) successfully related the basal crop coefficient $K_{\mathrm{cb}}$ for bean plants to PGC, demonstrating its strong dependence on canopy size using the following equation:

$\mathrm{K}_{\mathrm{cb}}=0.320+3.0 \times 10^{-4} \mathrm{PGC}+5.5 \times 10^{-4} \mathrm{PGC}^{2}-2.5 \times 10^{-6} \mathrm{PGC}^{3}$

The authors obtained a strong relationship between the $K_{c b}$ parameter and canopy development, obtaining a squared correlation coefficient of 0.97 and a P-value less than 0.01 .

For onions, Lopez-Urrea et al. (2009) observed linear relationships between the $K_{c}$ and $K_{c b}$ values obtained from lysimetric measurements and PGC:

$K_{\mathrm{c}}=0.811 \mathrm{PGC}+0.597 ; \quad K_{\mathrm{cb}}=0.7792 \mathrm{PGC}+0.5261$

The linear regression analysis carried out by the authors yielded squared correlation coefficients of 0.922 for $\mathrm{K}_{\mathrm{c}}$ and 0.911 for $\mathrm{K}_{\mathrm{cb}}$, demonstrating the strong linear dependence of the $K_{\mathrm{c}}$ and $K_{\mathrm{cb}}$ parameters on PGC in onion crops.

In addition to the above mentioned studies, another important work by Grattan et al. (1998) attempted to establish a direct relationship between the percentage of ground cover and the crop coefficient $K_{c}$ for seven vegetable crops in California, USA. The authors measured the $K_{c}$ values using Bowen ratio systems, thereby ensuring data accuracy. In the study, the authors affirmed that the crop coefficients changed as a quadratic function of the percentage of ground cover for most crops that achieve full cover ( $100 \%$ ground cover). The authors used quadratic expressions to fit data from all seven crops and obtained squared correlation coefficients of 0.60 for artichokes, 0.69 for beans, 0.74 for broccoli, 0.63 for lettuce, 0.90 for melons, 0.72 for onions and 0.87 for strawberries.

For lettuce, the polynomial equation proposed by the authors is the following:

$\mathrm{K}_{\mathrm{c}}=-0.00003 \mathrm{PGC}^{2}+0.012 \mathrm{PGC}+0.083$

This equation yields a squared correlation coefficient of only 0.63, demonstrating that a direct relationship between the percentage of ground cover and the crop coefficient $K_{c}$ cannot be established for lettuce crops. This case is also confirmed by the study carried out by Allen and Pereira (2009), who obtain similar results after complex calculations that require measuring not only the fraction of ground covered or shaded by vegetation but also the height of the vegetation and the amount of stomatal regulation under moist soil conditions.

One solution in this case is to determine an indirect relationship between evapotranspiration and the percentage of ground cover for lettuce crops. The method proposed in this paper first estimates the plant height using the value of PGC and then calculates the crop coefficient $K_{c}$ based on the term PGC/h. The results demonstrate the validity of the method in lettuce crops, yielding squared correlation coefficients very close to 1 and low values of RMSEP for every correlation (Table 1).
Although the proposed method has only been validated for lettuce crops, the promising results obtained here represent a basis for the potential application of the proposed method in other horticultural crops, such as kohlrabi and melons.

\section{Conclusions}

The paper presents a new computer vision-based method for estimating the crop coefficient $K_{c}$ of lettuce crops based on digital photographs of the vegetation cover. For this calculation, the plant height $h$ is first estimated from the PGC parameter; then, the term PGC/h is correlated with the crop coefficient $K_{c}$. This allows two mathematical equations to be derived with which to model the relationships between these parameters; squared correlation coefficients of 0.993 and 0.979 were obtained when estimating $h$ from PGC and when calculating $K_{c}$ from the term $P G C / h$, respectively, demonstrating the validity of the method.

The results provided by these equations were also validated during three crop seasons (October 2009-February 2010, October 2010-February 2011 and October 2011-January 2012), yielding correlation coefficients of $0.990,0.994$ and 0.990 (respectively) when comparing the real and estimated values of the plant height, and of $0.977,0.976$ and 0.978 (respectively) when comparing the real and estimated values of $K_{c}$; thus, this method performed better than the previous works found in the literature.

The real and estimated $K_{c}$ values obtained using this method were also compared with the values proposed by FAO-56 (Allen et al., 1998) for lettuce crops in a Mediterranean climate. The results demonstrated that FAO crop coefficients were obtained for specific agroclimatic conditions, which are different from the conditions existing in the study area. This reveals the need to adjust $K_{c}$ values to the agroclimatic conditions of the cultivation area. In contrast, the proposed methodology allows crop coefficients that are fitted to given climate conditions and crop development stages to be obtained.

\section{R E F E R E N C E S}

Ahamed, T., Tian, L., Jiang, Y. S., Zhao, B., Liu, H., \& Ting, K. C. (2012). Tower remote-sensing system for monitoring energy crops; image acquisition and geometric corrections. Biosystems Engineering, 112(2), 93-107.

Allen, R. G., \& Pereira, L. S. (2009). Estimating crop coefficients from fraction of ground cover and height. Irrigation Science, 28(1), 17-34.

Allen, R. G., Pereira, L. S., Howell, T. A., \& Jensen, M. E. (2011). Evapotranspiration information reporting: I. Factors governing measurement accuracy. Agricultural Water Management, 98(6), 899-920.

Allen, R. G., Pereira, L. S., Raes, D., \& Smith, M. (1998). Crop evapotranspiration: Guidelines for computing crop water requirements. FAO irrigation and drainage papers (pp. 328). Rome, Italy.

Blasco, J., Aleixos, N., Roger, J. M., Rabatel, G., \& Molto, E. (2002). Robotic weed control using machine vision. Biosystems Engineering, 83(2), 149-157. 
Bowen, I. S. (1926). The ratio of heat losses by conduction and by evaporation from any water surface. Physical Review, 27(6), 779-787.

Boyd, N. S., Gordon, R., \& Martin, R. C. (2002). Relationship between leaf area index and ground cover in potato under different management conditions. Potato Research, 45(2-3), 117-129.

Campillo, C., Garcia, M. I., Daza, C., \& Prieto, M. H. (2010). Study of a non-destructive method for estimating the leaf area index in vegetable crops using digital images. Hortscience, 45(10), 1459-1463.

Congling, W., Guanghui, T., \& Changying, L. (2005). Application and validation of computer vision based nondestructive measurement system for cucumber seedling growth conditions. Transactions of the CSAE, 21(4), 109-112.

De Medeiros, G. A., Arruda, F. B., Sakai, E., \& Fujiwara, M. (2001). The influence of crop canopy on evapotranspiration and crop coefficient of beans (Phaseolus vulgaris L.). Agricultural Water Management, 49(3), 211-224.

Doorenbos, J., \& Pruitt, W. O. (1977). Crop water requeriments. Rome: FAO. FAO irrigation and drainage paper no. 24.

Fortin, J. G., Parent, L. E., Anctil, F., \& Bolinder, M. A. (2008). Neural network to simulate potato tuber yield in Eastern Canada. Acta Horticulturae, 802, 309-318.

Giacomelli, G. A., Ling, P. P., \& Kole, J. (1998). Determining nutrient stress in lettuce plants with machine vision technology. HortTechnology, 8(3), 361-365.

Giacomelli, G. A., Ling, P. P., \& Morden, R. E. (1996). An automated plant monitoring system using machine vision. Acta Horticulturae, 440, 377-382.

Goncalves, J. M., Muga, A. P., Horst, M. G., \& Pereira, L. S. (2011). Furrow irrigation design with multicriteria analysis. Biosystems Engineering, 109(4), 266-275.

Grant, O. M., Davies, M. J., Longbottom, H., \& Harrison-Murray, R. (2012). Evapotranspiration of container ornamental shrubs: modelling crop-specific factors for a diverse range of crops. Irrigation Science, 30(1), 1-12.

Grattan, S. R., Bowers, W., Dong, A., Snyder, R. L., Carroll, J. J., \& George, W. (1998). New crop coefficients estimate water use of vegetables, row crops. California Agriculture, 52(1), 16-21.

Hanson, B. R., \& May, D. M. (2005). Crop coefficients for dripirrigated processing tomato. Agricultural Water Management, 81(3), 381-399.

Kirk, K., Andersen, H. J., Thomsen, A. G., Jorgensen, J. R., \& Jorgensen, R. N. (2009). Estimation of leaf area index in cereal crops using red-green images. Biosystems Engineering, 104(3), 308-317.
Ling, P. P., \& Ruzhitsky, V. N. (1992). Transplant uniformity inspection using machine vision. Acta Horticulturae, 319, $607-612$.

Lopez-Urrea, R., Olalla, F. M. d. S., Montoro, A., \& LopezFuster, P. (2009). Single and dual crop coefficients and water requirements for onion (Allium cepa L.) under semiarid conditions. Agricultural Water Management, 96(6), 1031-1036.

Lorente, D., Aleixos, N., Gómez-Sanchis, J., Cubero, S., GarcíaNavarrete, O. L., \& Blasco, J. (2012). Recent advances and applications of hyperspectral imaging for fruit and vegetable quality assessment. Food and Bioprocess Technology, 5(4), 1121-1142.

Lu, H. Y., Lu, C. T., Wei, M. L., \& Chan, L. F. (2004). Comparison of different models for nondestructive leaf area estimation in taro. Agronomy Journal, 96(2), 448-453.

Molina-Martínez, J. M., Jiménez, M., Ruiz-Canales, A., \& Fernández-Pacheco, D. G. (2011). RaGPS: a software application for determining extraterrestrial radiation in mobile devices with GPS. Computers and Electronics in Agriculture, 78(1), 116-121.

Ohmura, A. (1982). Objective criteria for rejecting data for Bowen ratio flux calculations. Journal of Applied Meteorology, 21(4), 595-598.

Oron, G., DeMalach, Y., Gillerman, L., David, I., \& Lurie, S. (2002). Effect of water salinity and irrigation technology on yield and quality of pears. Biosystems Engineering, 81(2), 237-247.

Story, D., Kacira, M., Kubota, C., Akoglu, A., \& An, L. L. (2010). Lettuce calcium deficiency detection with machine vision computed plant features in controlled environments. Computers and Electronics in Agriculture, 74(2), 238-243.

Xiang, H. T., \& Tian, L. (2011). Method for automatic georeferencing aerial remote sensing (RS) images from an unmanned aerial vehicle (UAV) platform. Biosystems Engineering, 108(2), 104-113.

Xiao, L., Tingfangzi, T., Suiliang, H., \& Yang, L. (2011). Image processing based non-destructive method for measuring growth of constructed wetland plants. In Proceedings of the 5th international conference on bioinformatics and biomedical engineering (iCBBE) (pp. 1-4).

Xu, X. G., Wang, J. H., Li, C. J., Song, X. U., \& Huang, W. J. (2010). Estimating growth height of winter wheat with remote sensing. In Proceedings of the SPIE 7824, remote sensing for agriculture, ecosystems, and hydrology XII. 


\subsection{Publicación 3}

\section{Digital photography applied to irrigation management of Little Gem lettuce}

D. Escarabajal-Henarejos ${ }^{1}$, J.M. Molina-Martínez ${ }^{1}$, D.G. Fernández-Pacheco², F. CavasMartínez $^{2}$, G. García-Mateos ${ }^{3}$

${ }^{1}$ Grupo de Investigación en Ingeniería Agromótica y del Mar. Universidad Politécnica de Cartagena, $\mathrm{P}^{\mathrm{o}}$ Alfonso XIII 52, 30203 Cartagena, Murcia.

${ }^{2}$ Departamento de Expresión Gráfica. Universidad Politécnica de Cartagena, Campus de la Muralla del Mar, C/ Doctor Fleming s/n, 30202 Cartagena, Murcia.

${ }^{3}$ Departamento de Informática y Sistemas. Facultad de Informática. Universidad de Murcia, Campus Universitario de Espinardo, 30100 Murcia.

\section{RESUMEN}

El principio fundamental de una buena gestión del riego consiste en mantener cubiertas las necesidades hídricas del cultivo, al mismo tiempo que se llevan a cabo estrategias de optimización para conseguir unos resultados agronómicos rentables con el menor consumo de agua posible. En base a este principio, se han incorporado nuevas técnicas a los diversos métodos de programación del riego, que facilitan la consecución de estos objetivos. Entre éstas, se ha generalizado rápidamente la adquisición de fotografías digitales en proyección vertical cuyo tratamiento informático permite obtener parámetros 
relacionados con el desarrollo del cultivo, vinculados al cálculo de sus requerimientos hídricos. La fracción de cobertura vegetal, obtenida aplicando técnicas de clasificación supervisada a fotografías digitales de la cubierta vegetal, es un parámetro de gran utilidad en la determinación de las necesidades hídricas de los cultivos según la metodología propuesta por la FAO-56, pues ha sido relacionado directamente con el coeficiente de cultivo. En este trabajo se ha llevado a cabo la programación del riego, basándose en el balance hídrico del suelo, de un cultivo comercial de lechuga variedad 'Little Gem' empleando la fotografía digital como herramienta para la obtención de las necesidades hídricas a través del coeficiente de cultivo. Los resultados obtenidos fueron comparados con la gestión del riego real llevada a cabo en la parcela de ensayo, monitorizada por medio de sondas de humedad del suelo, con el fin de analizar las deficiencias de gestión y cuantificar el exceso de agua de riego aplicada al cultivo. En resumen, se logró un aumento del 6,93\% en la producción y una reducción del 17,80\% en el consumo de agua en comparación con la parcela de referencia.

\section{INTRODUCCIÓN}

Las actuales exigencias a las que está sometida la agricultura obligan a establecer un compromiso entre producción y sostenibilidad, requiriendo un uso eficiente de los factores de producción y una gestión adecuada de los mismos. El uso sostenible del agua, como recurso productivo estratégico cada vez más escaso, supone uno de los principales retos de la agricultura del futuro, y hace necesaria la adopción de nuevas herramientas y metodologías que aumenten la eficiencia del uso del agua, manteniendo los niveles de producción (Molina-Martínez et al., 2011; Zhang y Kovacs, 2012).

En este contexto, la fotografía digital y las técnicas de procesamiento de imágenes han adquirido gran relevancia y se han convertido en una de las principales fuentes de información en tiempo real sobre diversos parámetros relacionados con el desarrollo y estado hídrico de los cultivos (Blasco et al., 2009; Lorente et al., 2012). Esta metodología se ha aplicado con éxito en varios campos de la investigación: determinación de la diferencia de color y fertilidad en cultivos de maíz (Ewing y Horton, 1999), evaluación de la porosidad en barreras rompevientos (Kenney, 1987), cuantificación del número de flores de un árbol (Adamsen et al., 2000) o estimación del índice de área foliar en cebolla (Corcoles et al., 2013). Sin embargo, su aplicación también se extiende a otras disciplinas como la silvicultura; por ejemplo, Meir et al. (2000) desarrollaron un método basado en la fotografía digital para medir la distribución vertical de la densidad de área foliar en 
bosques y Brown et al. (2000) estimaron las dimensiones de la copa en árboles llevando a cabo el análisis digital de fotografías verticales.

Una de las aplicaciones de la fotografía digital a la programación del riego está basada en la determinación de la fracción de cobertura del dosel vegetal (Calera et al., 2001). El dosel vegetal regula los intercambios de masa y energía, y controla el funcionamiento de los procesos hidrológicos a través de la modificación de la infiltración, escorrentía y evapotranspiración (Cayrol et al., 2000). La fracción de cobertura vegetal $(P G C)$ es un parámetro biofísico utilizado para representar distintas funciones de crecimiento y desarrollo de los cultivos (Walthall et al., 2004; Laliberte et al., 2007; Richardson et al., 2001).

Este $P G C$ permite estimar las necesidades hídricas de los cultivos al estar directamente relacionado con la evapotranspiración $(E T c)$, la cual es calculada como el producto del coeficiente de cultivo $(K c)$ y la evapotranspiración de referencia (ETo) (Allen et al., 1998; Allen et al., 2011). Diversos autores han logrado obtener resultados satisfactorios al relacionar $P G C$ con el coeficiente de cultivo $K c$ en tomates (Hanson y May, 2005), judías (De Mederios et al., 2001) y cebollas (Lopez-Urrea et al., 2009). En lechuga, Fernández-Pacheco et al. (2014) desarrollaron una nueva metodología basada en el procesamiento digital de imágenes para estimar el coeficiente de cultivo a partir de fotografias digitales de la cobertura vegetal. De forma adicional, otros trabajos desarrollados recientemente han conseguido también relacionar la fracción de cobertura vegetal con la profundidad radicular (Escarabajal-Henarejos et al., 2014). El conocimiento del valor de profundidad radicular en cada momento del desarrollo del cultivo permite optimizar las metodologías existentes de programación del riego basadas en el conocimiento del estado hídrico del suelo, consiguiendo establecer así un balance hídrico ajustado únicamente a la zona de absorción radicular.

El presente trabajo desarrolla la aplicación de la fotografía digital y de técnicas de procesamiento digital de imágenes para la estimación de las necesidades hídricas de un cultivo de lechuga (Lactuca sativa L. cv. 'Little Gem') como herramientas sencillas y novedosas aplicadas a la gestión hídrica de cultivos hortícolas, que permiten establecer la programación del riego del cultivo en base a las componentes del balance hídrico calculadas. Los resultados obtenidos han sido comparados con la gestión real del riego ajustada en base a criterios objetivos del regante de la explotación. 


\section{MATERIALES Y MÉTODOS}

\subsection{Parcela experimental}

El ensayo fue desarrollado en una parcela destinada al cultivo comercial de lechuga (Lactuca sativa L. cv. 'Little Gem'), situada en San Javier (latitud 37²4'04' 'N, longitud 049'34' 'W y altitud $15 \mathrm{~m}$ ) en la provincia de Murcia, Spain. La parcela tiene una superficie aproximada de 8,3 ha, las plantas de lechuga fueron obtenidas en semillero aparte y trasplantadas siempre a la misma densidad de plantación de 16,5 plantas $\cdot \mathrm{m}^{-2}$.

En el ensayo se utilizaron tres plantaciones de lechuga, todas ellas pertenecientes a la temporada otoño-invierno, y desarrolladas durante los meses de octubre a diciembre de los años 2011, 2012 y 2013. Durante la plantación correspondiente a 2011 se calibraron las ecuaciones derivadas de la metodología propuesta por Fernández-Pacheco et al. (2014), que fueron validadas posteriormente durante las plantaciones de 2012 y 2013. Además, la plantación correspondiente a 2013 sirvió para la aplicación de dichas ecuaciones y metodologías de programación del riego, para llevar a cabo su gestión del riego (Fig. 2.1).

El riego del cultivo se llevó a cabo mediante el empleo de aguas procedentes del Trasvase Tajo-Segura, con una conductividad eléctrica de $2,17 \mathrm{mS} / \mathrm{cm}$ y $\mathrm{pH}=7,85$, aplicada mediante un sistema automatizado de riego localizado. Con el objetivo de obtener la misma pluviometría se colocó una tubería emisora por cada línea pareada de plantas con goteros cada $30 \mathrm{~cm}$, de $21 \cdot h^{-1}$ de descarga unitaria en las líneas pareadas simples y $11 \cdot \mathrm{h}^{-1}$ de descarga unitaria en las líneas pareadas dobles. El suelo de la parcela está clasificado como "Calcic Petrocalcids" y tiene una profundidad media alrededor de $40 \mathrm{~cm}$, limitado por el desarrollo de un horizonte petrocálcico más o menos fragmentado. La textura predominante es franco-arcillo-arenosa (Arena: 55,25\%, Limo: 15,00\% y Arcilla: 29,75\%) con un contenido de humedad a capacidad de campo (CC) del 25\% y un punto de marchitez permanente (PMP) del 17\% (Saxton y Rawls, 2006).

El clima de la zona es Mediterráneo subdesértico. Durante las tres plantaciones utilizadas, correspondientes a los años 2011, 2012 y 2013, las condiciones termométricas fueron similares. La temperatura media máxima fue de $22,2,21,1$ y $22,7^{\circ} \mathrm{C}$, respectivamente, y la temperatura media mínima de $11,1,10,9$ y $10,3^{\circ} \mathrm{C}$, respectivamente, situándose en los tres casos la temperatura media durante el ciclo de cultivo en torno a $\operatorname{los} 15,3^{\circ} \mathrm{C}$. Durante la plantación correspondiente a 2011, el volumen de precipitación 
total acumulado fue de $137,80 \mathrm{~mm}$; no obstante este valor se redujo prácticamente a la mitad durante las dos siguientes plantaciones, en el que las precipitaciones fueron escasas e irregularmente distribuidas, registrándose un volumen total acumulado de 75,12 mm (2012) y 62,30 mm (2013), valores en sincronía al tratarse de dos años excepcionalmente secos. Los niveles de precipitación fueron registrados usando un pluviómetro RAIN-OMATIC (Campbell Scientific, Logan, UT, USA), el cual estaba incluido en una estación meteorológica situada en la parcela experimental.
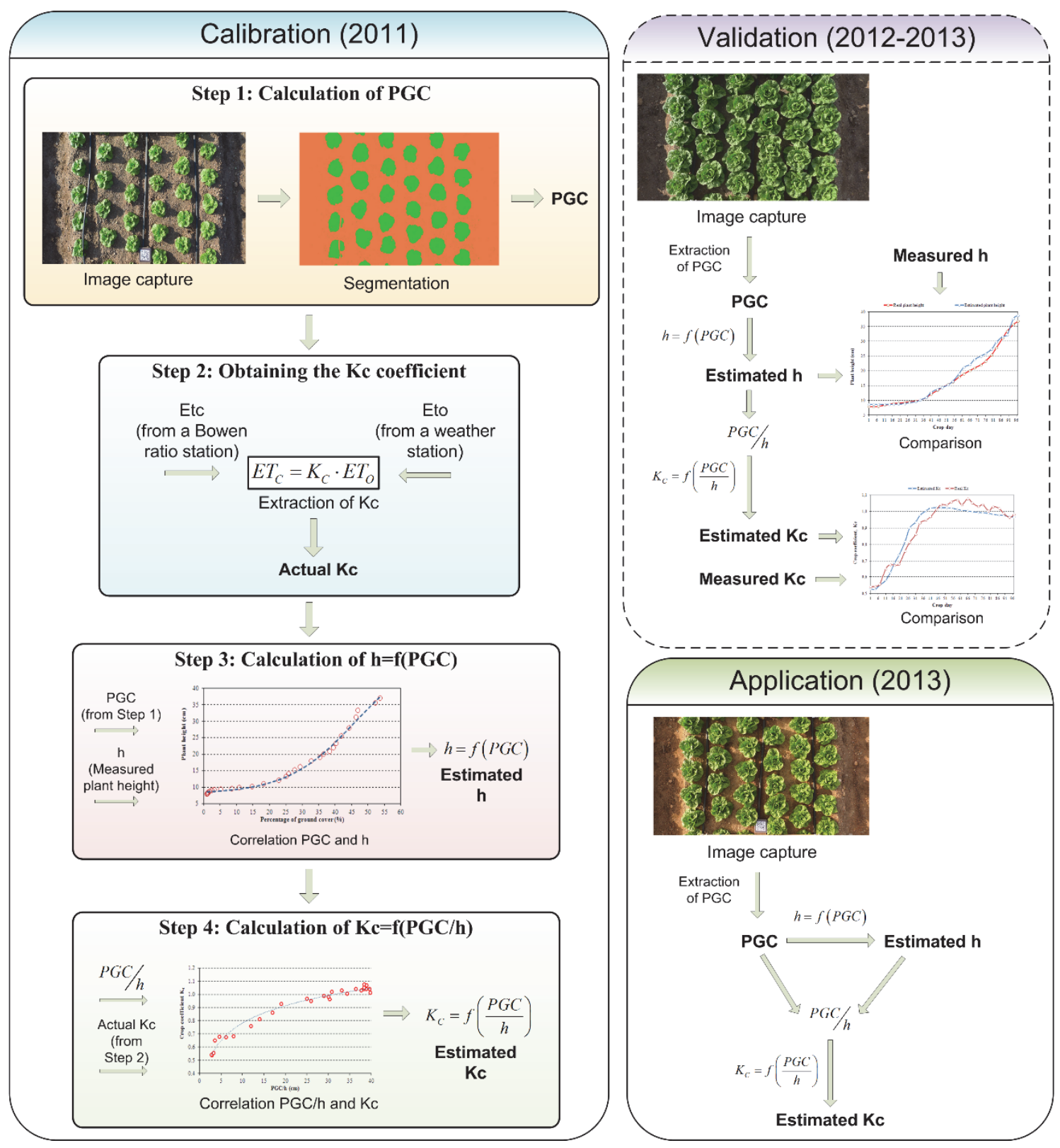

Fig. 2.1. Esquema de la metodología aplicada. 


\subsection{Gestión del riego}

Para llevar a cabo la gestión del riego en el cultivo de lechuga, la parcela experimental fue dividida en dos subparcelas, cada una de las cuales correspondiente a un sector de riego, de tal manera que se pudieran efectuar riegos independientes en cada una de ellas. En ambas parcelas se mantuvieron las mismas condiciones de cultivo y misma densidad de plantación. No obstante, el riego fue gestionado de manera diferente a fin de establecer criterios de riego y proporcionar un posterior asesoramiento al regante.

Una de las parcelas, denominada 'patrón', tiene una superficie de 4,6 ha, y en ella el riego fue gestionado en base a criterios objetivos y propia experiencia del regante de la explotación, sin intervenir en la toma de decisiones de riego. La monitorización de los riegos se llevó a cabo mediante la medición del contenido de humedad del suelo. Para ello, se instaló un equipo $\mathrm{ECH}_{2} \mathrm{O}$ (Decagon Devices Inc., WA, USA) compuesto por 3 sensores capacitivos FDR modelo 10HS, High Speed, instalados a 15, 30 y $45 \mathrm{~cm}$ de profundidad, cuyos datos horarios eran registrados y almacenados por un datalogger Em50G (Decagon Devices Inc., WA, USA).

En la otra parcela, denominada 'experimental', de 3,7 ha, el riego fue gestionado estableciendo el balance hídrico en la zona radicular para determinar el contenido de humedad del suelo y determinar el momento óptimo de riego. Dado que el cultivo se riega mediante un sistema de riego localizado, éste permite frecuentes aportaciones de baja cantidad de agua, lo que produce elevados rendimientos y altas eficiencias en el uso del agua, obteniéndose la máxima producción cuando la humedad del suelo es alta y continua en toda la fase vegetativa del cultivo (Berth y Homna, 1974; Rincón, 2001; Sutton y Merit, 1993). Esto permitió mantener la humedad del suelo en umbrales próximos a la capacidad de campo durante todo el ciclo de cultivo del estudio (Salter y Goode, 1967).

\subsection{Balance de agua en el suelo}

En la parcela experimental, las necesidades de riego del cultivo fueron estimadas a partir del balance hídrico en la zona radicular. El balance de agua en el suelo se puede expresar como:

$$
\left(\Theta_{t}-\theta_{t-1}\right) \cdot z=P+I-D-E T-R
$$

donde $\theta_{t-1}$ y $\theta_{t}$ son los contenidos volumétricos de humedad en el suelo inicial y final, respectivamente $\left(\mathrm{cm}^{3} \cdot \mathrm{cm}^{-3}\right), z$ es la profundidad radicular del cultivo $(\mathrm{cm}), P$ es la precipitación $(\mathrm{mm}), I$ es el riego $(\mathrm{mm}), D$ es el drenaje fuera de la zona radicular $(\mathrm{mm})$, 
$E T$ es la evapotranspiración $(\mathrm{mm})$ y $R$ es la escorrentía superficial $(\mathrm{mm})$, aunque este último parámetro se consideró despreciable al tratarse de riego localizado.

La evapotranspiración del cultivo, ET, fue calculada como el producto de la evapotranspiración de referencia ( $\left.E T_{0}\right)$ y el coeficiente de cultivo (Kc) (Allen et al., 1998). $E T_{0}$ fue calculada por el método de Penman-Monteith (Allen et al., 1998):

$$
\mathrm{ET}_{0}=\frac{0.408 \Delta\left(R_{n}-G\right)+\frac{900}{T+273} \gamma u_{2}\left(e_{s^{-}}-e_{a}\right)}{\Delta+\gamma\left(1+0.34 u_{2}\right)}
$$

donde $R_{n}$ es la radiación neta en el cultivo de referencia $\left(\mathrm{MJ} \cdot \mathrm{m}^{-2} \cdot \mathrm{d}^{-1}\right), G$ es la densidad de flujo de calor en el suelo $\left(\mathrm{MJ} \cdot \mathrm{m}^{-2} \cdot \mathrm{d}^{-1}\right), T$ es la temperatura del aire a $2 \mathrm{~m}$ de altura $\left({ }^{\circ} \mathrm{C}\right), e_{s}$ es la presión de vapor de saturación $(\mathrm{kPa}), e_{a}$ es la presión real de vapor $(\mathrm{kPa}), \Delta$ es la pendiente de la curva de presión de vapor $\left(\mathrm{kPa}^{\circ} \mathrm{C}^{-1}\right)$, y $\gamma$ es la constante psicrométrica $\left(\mathrm{kPa} \cdot{ }^{\circ} \mathrm{C}^{-1}\right)$.

Todos los datos meteorológicos requeridos por la ecuación fueron registrados con la ayuda de una estación climática situada sobre el cultivo de referencia y muy próxima a la parcela experimental. La estación estaba equipada con un datalogger (CR10X, Campbell Scientific, Logan, UT, USA) y sensores de temperatura y humedad relativa del aire (sonda MP100, Campbell Scientific, Logan, UT, USA), radiación solar (piranómetro CM14, KIPP\&ZONEN Delft, Holland), velocidad y dirección del viento (anemómetro A100R y anemoveleta W200P, Vector Instruments Ltd., UK), y precipitación (pluviómetro ARG100, Campbell Scientific, Logan, UT). Las sondas de temperatura y humedad estaban colocadas a 1,5 m sobre el nivel del suelo, mientras que los sensores de viento se encontraban a 2,0 $\mathrm{m}$ de altura.

La estimación de los coeficientes de cultivo $K c$ para determinar ET se llevó a cabo empleando la metodología propuesta por Fernández-Pacheco et al. (2014). Esta metodología establece, en un primer paso, la relación matemática entre la altura del cultivo $(h)$ y la fracción de cobertura vegetal $(P G C)$ obtenida mediante procesamiento informático de imágenes digitales del dosel vegetal. El resultado inicial es una ecuación que permite estimar la altura del cultivo $\left(h_{e s t}\right)$ a partir de $P G C$. A continuación, la metodología calcula un parámetro intermedio $\left(P G C / h_{\text {est }}\right)$, el cual relaciona con los coeficientes de cultivo $K c$ obtenidos mediante aplicación del método de Bowen-Balance de Energía (RBBE) (Bowen, 1926). 
La metodología empleada fue previamente calibrada para el cultivo objeto del estudio (Lactuca sativa L. cv. 'Little Gem') en la misma finca, bajo condiciones climáticas similares y mismo ciclo de cultivo, durante los meses octubre-diciembre 2011, siendo utilizada y validada posteriormente en los años 2012 y 2013. Así pues, en el cultivo objeto del estudio se establecieron 4 zonas de muestreo donde se llevó a cabo un seguimiento de la evolución de la fracción de cobertura vegetal obtenida a partir de fotografías verticales del dosel vegetal mediante el empleo de una cámara digital compacta (Coolpix S3300, Nikon, Japón) equipada con un dispositivo de carga acoplado (CCD) (resolución, 16,0 megapíxeles; distancia focal, 27,6 mm) que estaba montada sobre un trípode a una altura fija de 1,40 m sobre el nivel del suelo. Las imágenes digitales obtenidas fueron procesadas con el software $\mathrm{ENVI}^{\circledR}$ versión 4.0 (Environment for Visualizing Images) (Research System Inc., Boulder, CO, USA), que permitió obtener: (i) una segmentación de las imágenes (Fig. 2.2) para diferenciar entre suelo (beige) y vegetación (verde), y (ii) el número de píxeles correspondientes a vegetación (V), suelo (S) y totales (T); por tanto, la fracción de cobertura vegetal se define como la relación $\mathrm{V} / \mathrm{T}$.

Adicionalmente, también se midió la altura del cultivo y se obtuvo la expresión matemática que relaciona $h$ con $P G C$. Finalmente, para obtener la segunda ecuación que permite estimar $K c$ a partir de la relación $P G C / h_{\text {est }}$, se determinaron in situ los coeficientes $K c$ mediante la aplicación del método de Bowen-Balance de Energía (BREB) y éstos fueron relacionados con $P G C / h_{\text {est }}$. Las ecuaciones obtenidas en la calibración llevada a cabo en 2011 fueron empleadas para obtener los coeficientes de cultivo $K c$ a aplicar en la determinación de $E T$.

\subsection{Programación del riego}

Para determinar el momento óptimo de aplicación del riego y llevar a cabo su programación, se establecieron los límites superior e inferior entre los que se mantuvo el contenido de humedad del suelo. Como límite superior se consideró el valor de humedad del suelo a capacidad de campo $\left(\Theta_{F C P}\right)$. El límite inferior indica el momento de aplicación del riego, y viene fijado por el contenido de humedad del suelo a máximo agotamiento permisible $\left(\Theta_{N A P}\right)$, contenido por debajo del cual el sistema radicular encuentra mayor dificultad para extraer agua, lo que produce una disminución en la transpiración y, en consecuencia, pérdidas de producción. El cálculo de $\Theta_{N A P}$ está basado en considerar una 
fracción de agotamiento permisible (f) (Doorenbos, 1977) que marca la amplitud entre el límite superior e inferior, y en consecuencia la frecuencia de aplicación de los riegos.

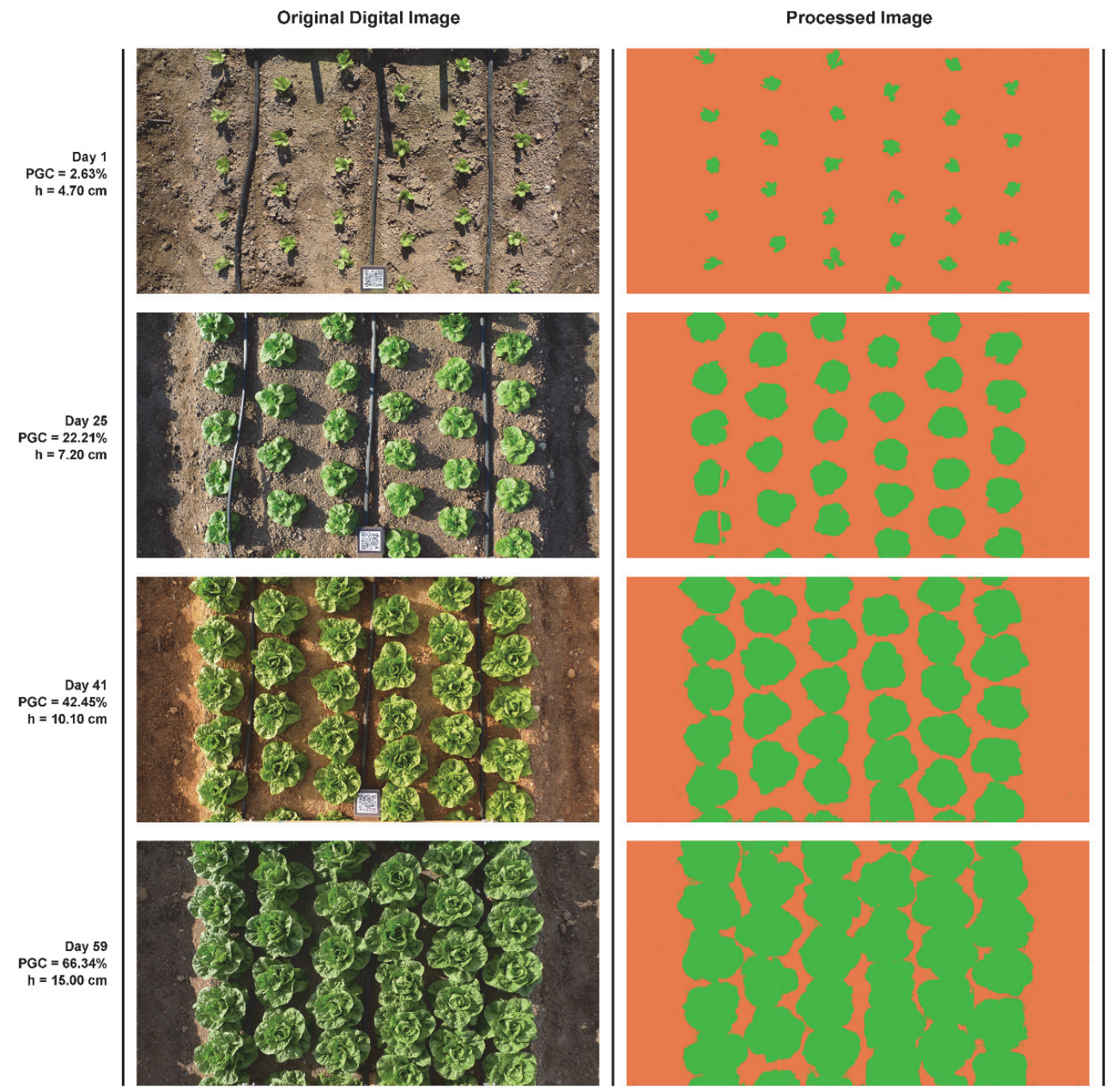

Fig. 2.2. Muestra de los resultados obtenidos usando el software de procesamiento de imágenes.

El valor de humedad del suelo correspondiente al límite inferior fue determinado según la siguiente ecuación:

$$
\theta_{N A P}=\theta_{F C P}-f \cdot\left(\theta_{F C P}-\theta_{P W P}\right)
$$

donde $\Theta_{N A P}$ representa el límite inferior o contenido de humedad del suelo a máximo agotamiento permisible (\%), $\Theta_{F C P}$ es el contenido de humedad del suelo a capacidad de campo (\%), ӨPWP es el contenido de humedad del suelo a punto de marchitez permanente (\%) y $f$ representa la fracción de agotamiento permisible. Con el objetivo de disminuir la evaporación directa y aumentar la transpiración de la planta, manteniendo un elevado contenido de humedad en las capas superficiales del suelo, se consideró una fracción de agotamiento permisible $f=0,15$ (Rincón, 2001). 


\section{RESULTADOS Y DISCUSIÓN}

\subsection{Metodología para la calibración de $K c$}

Para determinar la evapotranspiración del cultivo (ET) se aplicó la metodología FAO-56 (Allen et al., 1998). Esta metodología determina ET como el producto de la evapotranspiración de referencia $\left(E T_{0}\right)$ por un coeficiente de cultivo $(K c)$. Los coeficientes de cultivo diarios $(K c)$ fueron calculados empleando las ecuaciones obtenidas de la aplicación de la metodología propuesta por Fernández-Pacheco et al. (2014). Estas ecuaciones fueron obtenidas sobre el mismo cultivo y bajo condiciones climáticas similares, durante un periodo de 67 días desde octubre de 2010 a diciembre de 2011. Inicialmente se obtuvo una ecuación que relaciona los valores de $P G C$ obtenidos mediante procesamiento informático de imágenes digitales de la cubierta vegetal, y la altura del cultivo h. Para este ensayo, se analizaron varias funciones de aproximación, incluyendo la doble sigmoide, logística, función de Gompertz y función monomolecular. Los mejores resultados fueron obtenidos usando una función monomolecular (Ec. 4), donde $y=h(\mathrm{~cm}), x=P G C(\%), a=4,484$ y $b=0,017$.

$$
y=a \cdot e^{b \cdot x}
$$

Para evaluar el comportamiento de la ecuación, se compararon los valores de altura de cultivo medidos y estimados empleando la Ec. 4 (Fig. 2.3a). También se realizó un análisis de regresión lineal, obteniéndose una pendiente de la recta de regresión lineal muy similar a $1(0,944)$ y un coeficiente de correlación $\mathrm{R}^{2}$ de 0,995 (Tabla 2.1). La raíz cuadrada del error cuadrático medio (RMSE) fue de $0,065 \mathrm{~cm}$, lo que demuestra que la diferencia entre los valores reales y los valores pronosticados por el modelo fue mínima.

Finalmente, la relación entre el parámetro $P G C / h_{\text {est }}$ y el coeficiente de cultivo $K_{C}$ permitió obtener una función logarítmica que correlacionaba ambos (Ec. 5), donde $y=$ $K c, x=P G C / h_{\text {est }}(\% / \mathrm{cm}), a=0,163$ y $b=0,779$.

$$
y=a \cdot \ln (x)+b
$$

Los valores de $K c$ estimados usando esta ecuación fueron comparados con los valores reales de $K c$ obtenidos aplicando el método de Bowen-Balance de Energía (Fig. 2.3b); se realizó un análisis de regresión lineal (Tabla 2.1), obteniéndose una pendiente de la recta de regresión lineal muy similar a $1(0,949)$ y un coeficiente de correlación $\mathrm{R}^{2}$ de 0,977 (Tabla 2.1). RMSE fue $0,005 \mathrm{~cm}$. 


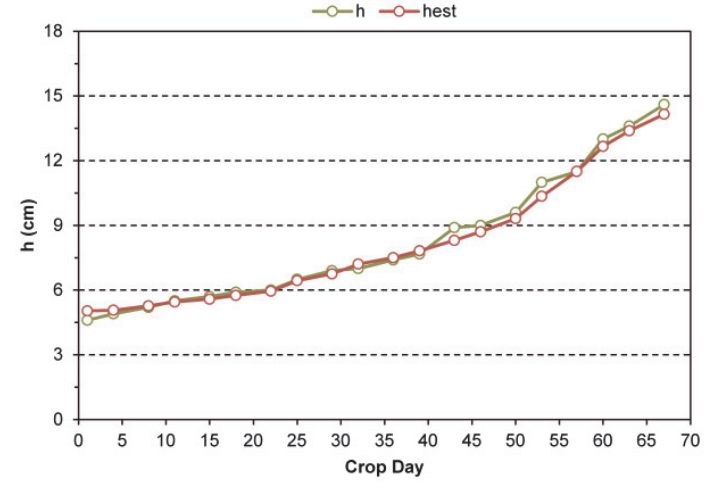

a)

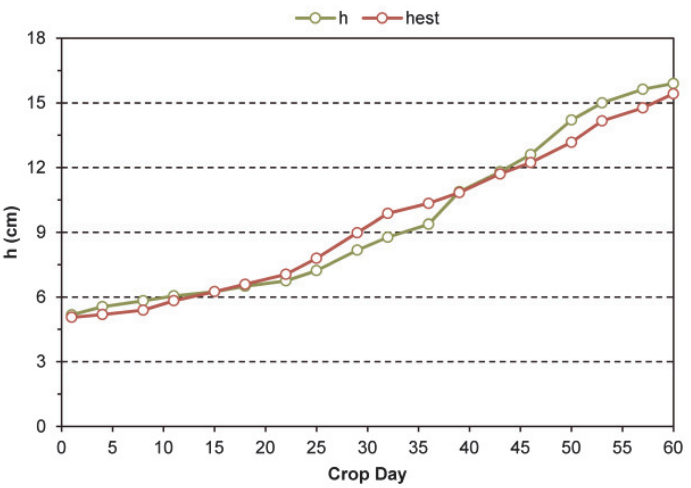

c)

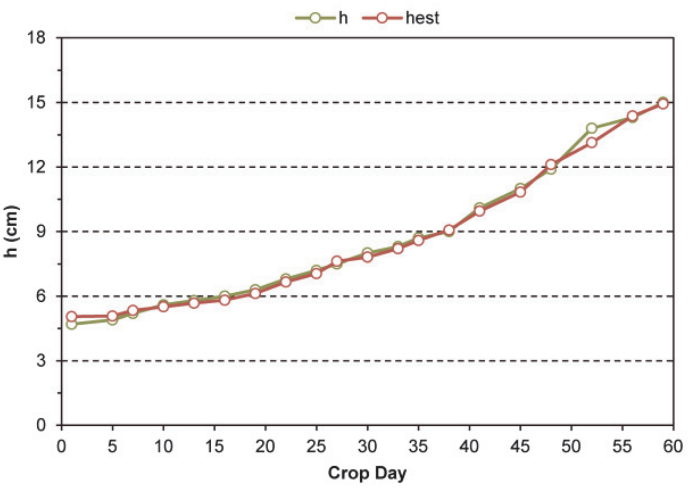

e)

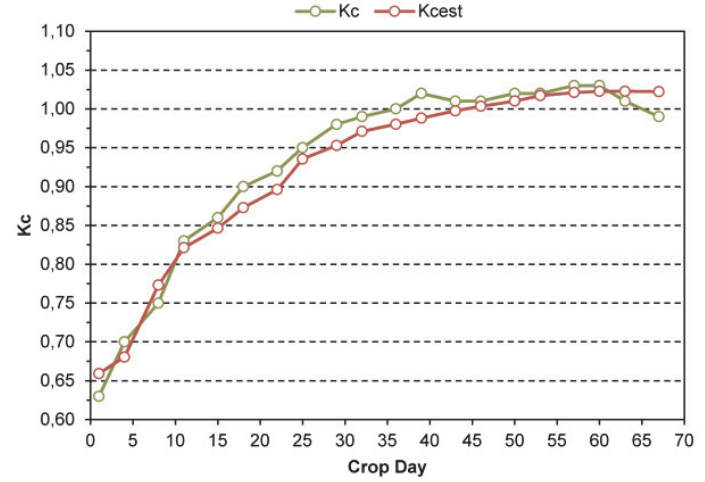

b)

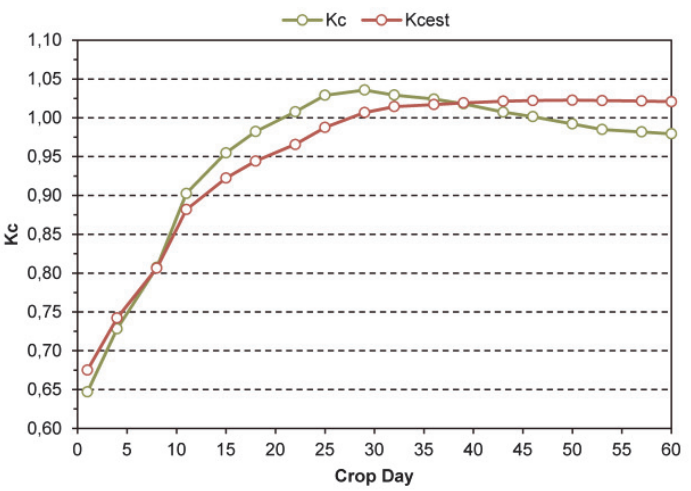

d)

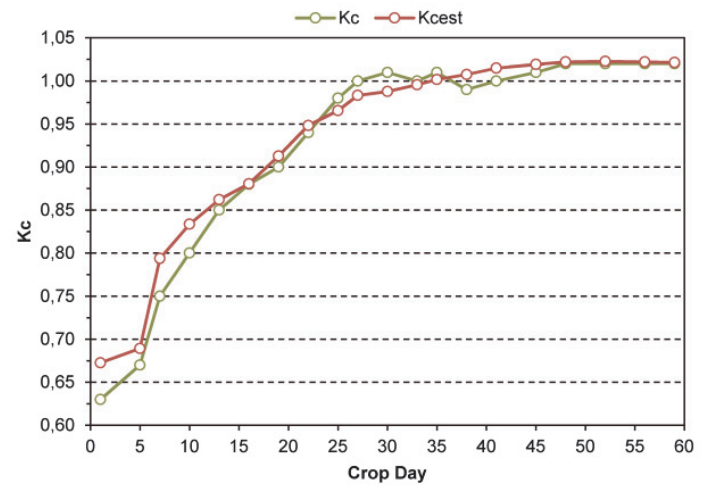

f)

Fig. 2.3. Comparación de los valores reales y estimados de altura de la planta y $K c$ durante: (a-b) el año de calibración 2011 (las ecuaciones fueron obtenidas aplicando la metodología propuesta por FernándezPacheco et al. (2014) en cultivo de lechuga Little Gem), (c-d) el año de validación 2012, y (e-f) el año de validación 2013. 
Tabla 2.1. Datos estadísticos del análisis de regresión lineal llevado a cabo al comparar los valores reales y estimados de altura de la planta y valores reales y estimados del coeficiente de cultivo $K c$ durante la calibración de la metodología.

\begin{tabular}{cllccccc}
\hline $\begin{array}{c}\mathrm{N} \\
\text { Figura }\end{array}$ & Parámetro X & Parámetro Y & Pendiente & Intersección & $\mathrm{R}^{2}$ & RMSE & $\begin{array}{c}\text { Tamaño } \\
\text { muestra }\end{array}$ \\
\hline $2.3 \mathrm{a}$ & $h$ real & $h$ estimada & 0,944 & $-0,033$ & 0,995 & 0,065 & 20 \\
$2.3 \mathrm{~b}$ & $K c$ real & $K c$ estimado & 0,949 & 0,039 & 0,977 & 0,005 & 20 \\
$2.3 \mathrm{c}$ & $h$ real & $h$ estimada & 0,920 & 0,700 & 0,977 & 0,141 & 18 \\
$2.3 \mathrm{~d}$ & $K c$ real & $K c$ estimado & 0,929 & 0,067 & 0,929 & 0,007 & 18 \\
$2.3 \mathrm{e}$ & $h$ real & $h$ estimada & 0,979 & $-0,086$ & 0,996 & 0,048 & 20 \\
$2.3 \mathrm{f}$ & $K c$ real & $K c$ estimado & 0,890 & $-0,111$ & 0,989 & 0,005 & 20 \\
\hline
\end{tabular}

La primera validación fue llevada a cabo durante un periodo de 60 días desde octubre a diciembre de 2012. Durante este periodo de validación, se realizaron dos comparaciones. En primer lugar, se analizó la relación entre la altura de la planta estimada y la altura de la planta medida, obteniéndose un buen ajuste (Fig. 2.3c). También se realizó un análisis de regresión lineal, produciendo un coeficiente de correlación $\mathrm{R}^{2}$ de 0,977 y una pendiente de la recta de regresión lineal de 0,920. En este caso, el valor obtenido de RMSE fue de 0,141 cm (Tabla 2.1). En segundo lugar, se compararon los valores reales y estimados de $K c$, observándose un notable acuerdo entre ambos valores durante todo el ciclo de crecimiento (Fig. 2.3d). Esta comparación fue también acompañada de un análisis de regresión lineal, el cual produjo un coeficiente de correlación $\mathrm{R}^{2}$ de 0,929 y una pendiente de la recta de regresión lineal de 0,929 (Tabla 2.1). Para este caso, se obtuvo un RMSE de 0,007.

La segunda validación fue llevada a cabo durante un periodo de 59 días desde octubre a diciembre de 2013. En la Fig. 2.3e se comparan los valores estimados y medidos de altura de la planta, produciendo un coeficiente de correlación $\mathrm{R}^{2}$ de 0,996 , una pendiente la recta de regresión línea de 0,979 y un RMSE de 0,048 (Tabla 2.1). Finalmente, la Fig. 2.3f muestra la relación entre los valores reales y estimados de $K c$, produciendo una pendiente de la recta de regresión lineal de 0,890, un coeficiente de correlación de 0,989 y un RMSE de 0,005 (Tabla 2.1).

Los coeficientes de cultivo $K c$ obtenidos durante 2013 mediante la utilización de la metodología propuesta por Fernández-Pacheco et al. (2014) fueron empleados en la estimación de la $E T$ del cultivo. El valor de $K c$ aumentó linealmente durante los primeros 35 días después del trasplante (Fig. 2.3f), variando desde 0,67 en los primeros días del cultivo a 1,02 en la fase de acogollado y hasta la recolección, valores ligeramente similares a los obtenidos por Rincón et al. (2007) en lechuga 'Iceberg' y Fernández- 
Pacheco et al. (2014) en lechuga variedad 'Hierro', al tratarse de variedades muy parecidas.

\subsection{Balance hídrico y programación del riego en la parcela experimental}

En la parcela experimental, el riego fue gestionado estableciendo el balance hídrico en la zona radicular del cultivo, para determinar posteriormente el contenido de humedad del suelo y el momento de aplicación del riego. A fin de ajustar el balance hídrico al perfil de suelo explorado por el sistema radicular de la planta, la profundidad radicular del cultivo (z) fue medida directamente en campo cada uno de los días muestreados. La Fig. 2.4 muestra la evolución de la profundidad radicular a lo largo del ciclo de cultivo. Ésta aumenta linealmente desde los $6 \mathrm{~cm}$ tras el trasplante a los $29 \mathrm{~cm}$ en la recolección, valores esperados en condiciones de riego por goteo y suelo franco-arcilloso (Rincón et al., 1991); no obstante, la mayor densidad radicular se concentra entre los 10 y $25 \mathrm{~cm}$.

Para el cálculo del balance hídrico se siguieron las recomendaciones propuesta por Rincón (2005) que establece determinados riegos en ciertos momentos del desarrollo del cultivo. Los riegos fueron programados para mantener el contenido de humedad del suelo en umbrales próximos a la capacidad de campo $(\mathrm{FCP}=25 \%)$ durante todo el ciclo de cultivo (Salter y Goode, 1967), evitando que el contenido de humedad del suelo descendiera por debajo del nivel de máximo agotamiento permisible (PDP $=23,8 \%$ ) (Fig. 2.5).

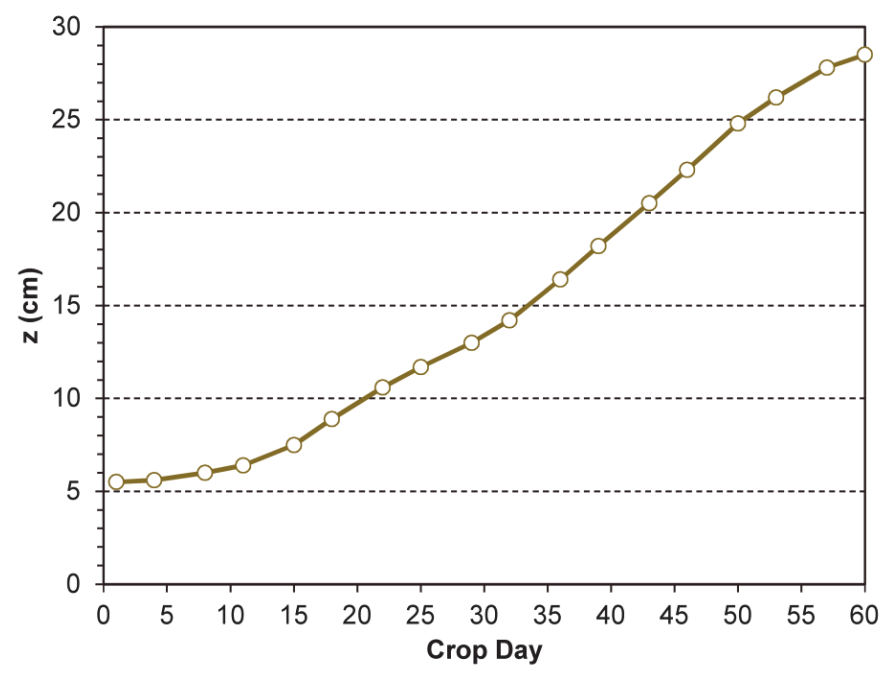

Fig. 2.4. Evolución de la profundidad radicular durante el ciclo de cultivo de lechuga 'Little Gem'. 


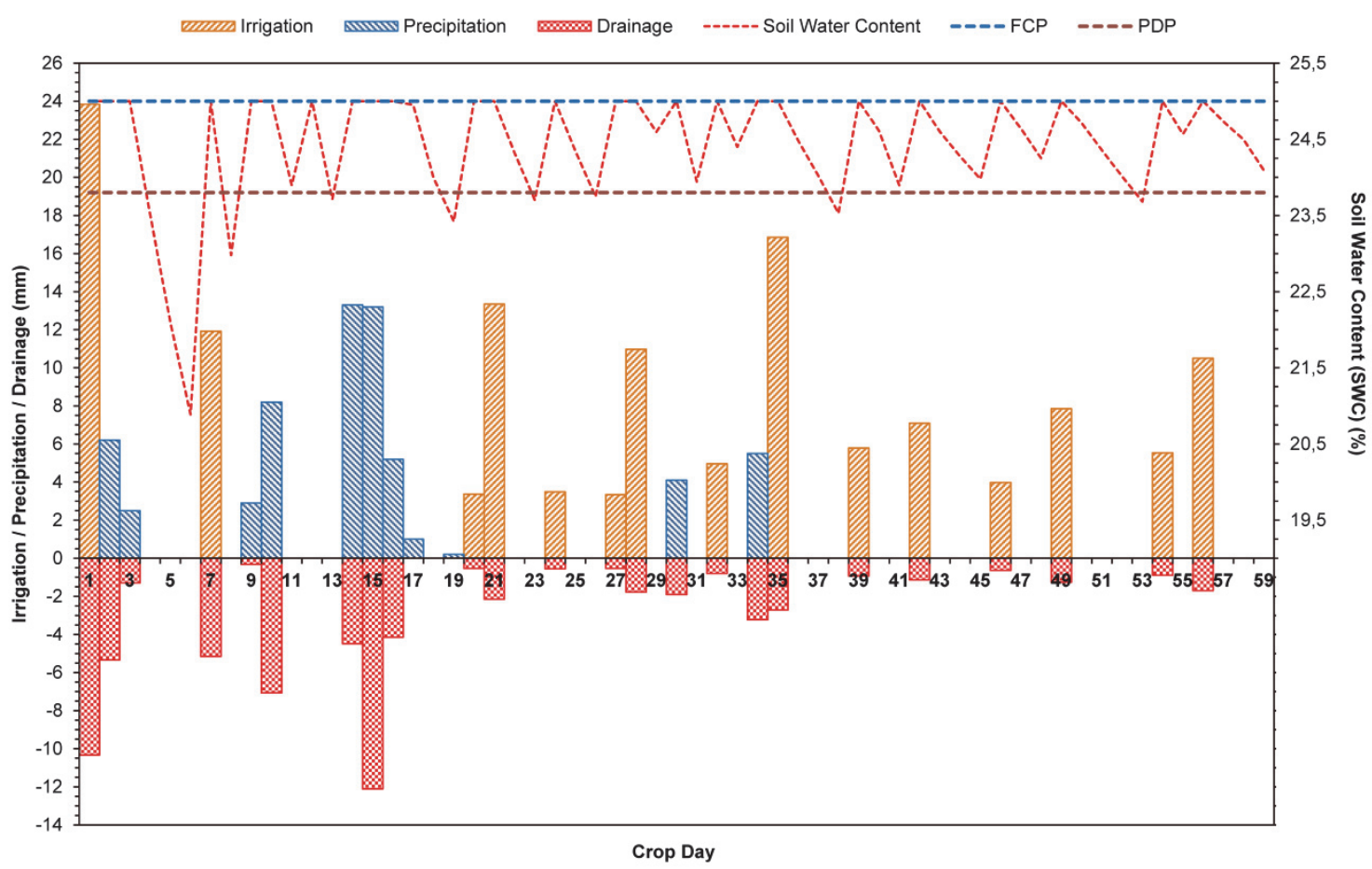

Fig. 2.5. Componentes del balance de agua en el suelo calculado y evolución del contenido de agua en el suelo en la zona radicular para el cultivo de lechuga 'Little Gem' situado en la parcela experimental.

Inicialmente se aplicó un riego de plantación para que todas las plántulas quedaran suficientemente regadas y fijadas al suelo. Al inicio del cultivo, la conductividad eléctrica del extracto de saturación del suelo (ECe) era de $1,18 \mathrm{mS} \cdot \mathrm{cm}^{-1}$, valor que se situó por debajo del umbral de tolerancia de la lechuga a la salinidad de $1,30 \mathrm{mS} \cdot \mathrm{cm}^{-1}$ (Ayers y Wescot, 1987), por lo que la salinidad inicial del suelo era lo suficientemente baja como para ser tolerada por el cultivo. Así pues, el aporte de agua en el riego de plantación no persiguió un lavado inicial de sales y simplemente fue estimado para elevar el contenido inicial de humedad del suelo (10\%) al valor de capacidad de campo (FCP $=25 \%)$. El riego de plantación depende del tipo y humedad inicial del suelo; en este caso se aplicaron 23,84 mm, valor que entra dentro del intervalo de 20-30 mm recomendado por Rincón (2005).

Durante los primeros días del crecimiento del cultivo, es práctica recomendable forzar a la planta a emitir un sistema radical extenso y vigoroso para potenciar la absorción de agua y nutrientes del suelo, así como que en el periodo de mayores extracciones la absorción se realice sin restricciones (Rincón, 2005). El forzado del sistema radicular se consiguió sometiendo a la planta a un déficit hídrico moderado. Así pues, el segundo riego no fue aplicado hasta transcurridos 6 días desde el trasplante, lo que hizo disminuir el contenido en humedad del suelo hasta un 20,9\%, valor justificado 
por el forzado del sistema radicular. Al sexto día se aplicó un segundo riego, denominado riego de arraigue, de 11,92 $\mathrm{mm}$, cuyo objetivo fue asegurar el establecimiento definitivo de las plántulas.

A partir del sexto día de plantación, los riegos fueron programados y ejecutados para mantener el contenido de humedad del suelo en umbrales próximos al FCP (Fig. 2.5), por lo que el intervalo entre riegos no excedió los 3-4 días. El ciclo de cultivo se alargó hasta los 59 días después del trasplante, en el que la ET total del cultivo fue de $61,64 \mathrm{~mm}$. El agua aplicada en los riegos posteriores al riego de arraigue fue de 97,07 mm y la aportada por la lluvia de $62,30 \mathrm{~mm}$, de la que el $84,6 \%$ se produjo en la fase de crecimiento lento y el 15,4\% en la fase de acogollado. El volumen total de riego aplicado en la parcela experimental fue de $132,83 \mathrm{~mm}$ y en dicha parcela se obtuvo una producción comercial total de lechuga confeccionada de $23.146 \mathrm{~kg} \cdot \mathrm{ha}^{-1}$ con un bajo porcentaje de destrío (8,56\%). La productividad del uso del agua fue de $17,43 \mathrm{~kg} \cdot \mathrm{m}^{-3}$.

\subsection{Evaluación de la programación del riego en la parcela patrón}

En la parcela patrón, el riego fue gestionado por el regante de la explotación, atendiendo a criterios objetivos y propia experiencia, limitándose el estudio únicamente al registro de los valores de humedad del suelo a 15,30 y $45 \mathrm{~cm}$ de profundidad para su posterior valoración. En esta parcela, en ningún caso se consideró la profundidad radicular del cultivo, tomándose como valores de referencia en la valoración los obtenidos en la parcela experimental. Dado que la profundidad radicular del cultivo no superó el valor de $15 \mathrm{~cm}$ hasta transcurridos 30 días desde el trasplante (Fig. 2.4), en este periodo se prestó mayor atención a los valores de humedad del suelo a $15 \mathrm{~cm}$ de profundidad ( $\left.\Theta_{15}\right)$ (Fig. 2.6), considerándose el movimiento de agua por debajo de los primeros $15 \mathrm{~cm}$ como agua drenada por el suelo. A partir del día 30, en el que la profundidad radicular supera los 15 cm hasta alcanzar los $29 \mathrm{~cm}$ en la recolección, se consideró también la humedad del suelo a $30 \mathrm{~cm}$ de profundidad $\left(\Theta_{30}\right)$ (Fig. 2.6), ya que la mayor densidad radicular se concentró entre los 10 y $25 \mathrm{~cm}$. Durante todo el cultivo, los valores de humedad del suelo a $45 \mathrm{~cm}$ de profundidad no representaron agua disponible para el cultivo, sino movimiento de agua hacia capas más profundas (drenaje). 


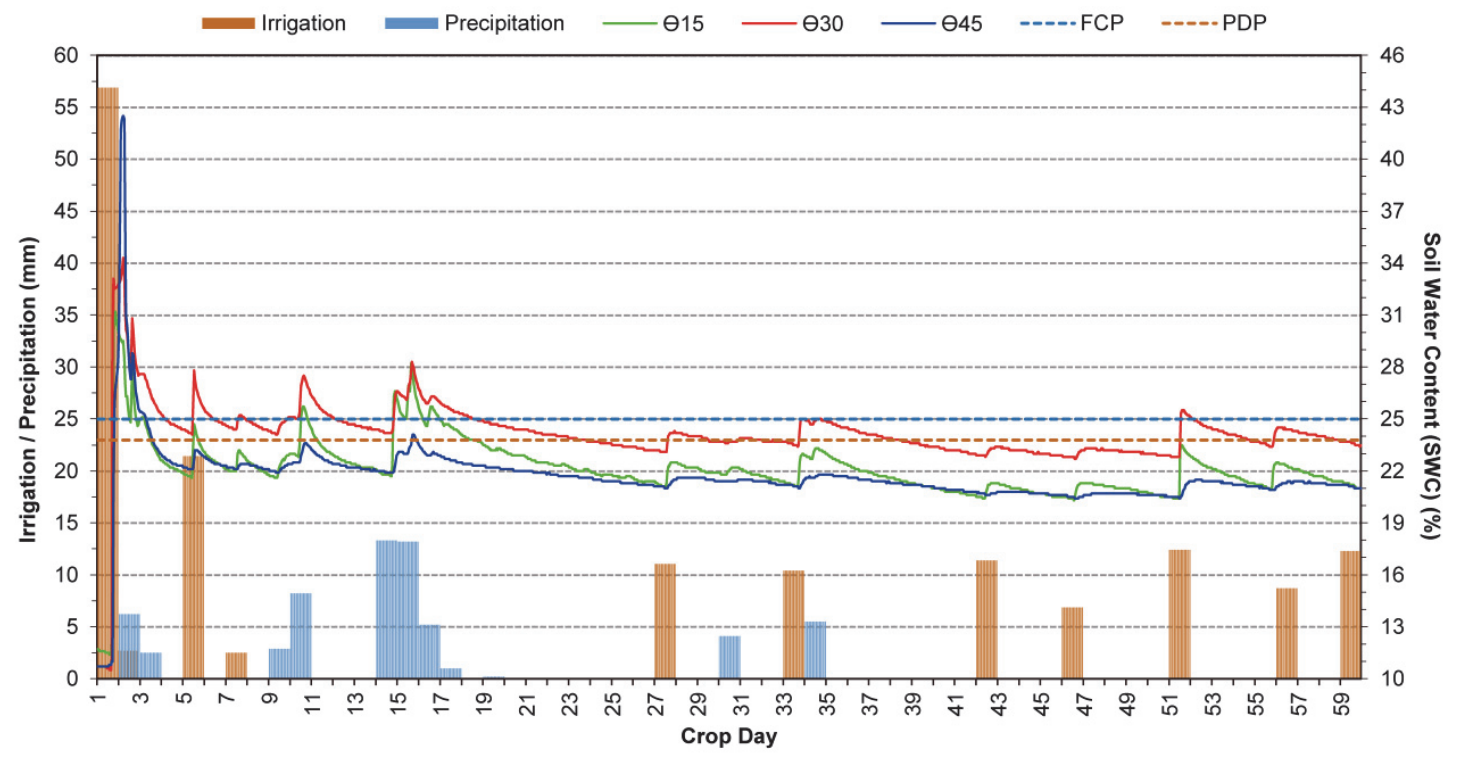

Fig. 2.6. Riego, precipitación y contenido de humedad del suelo a 15,30 y $45 \mathrm{~cm}$ de profundidad medido por sondas FDR para el cultivo de lechuga ‘Little Gem' situado en la parcela patrón.

La Fig. 2.6 muestra la evolución del contenido de humedad del suelo en los 3 perfiles de suelo considerados en la parcela patrón y los aportes de agua por riego y lluvia durante todo el ciclo de cultivo. El riego inicial de plantación aplicado por el regante en la parcela patrón fue de $56,89 \mathrm{~mm}, 33,05 \mathrm{~mm}$ superior al aplicado en la parcela experimental. Este riego inicial fue excesivo para elevar el contenido de humedad del suelo a capacidad de campo (FCP), dados los escasos requerimientos de lavado de sales del suelo denotados por su baja EC $\left(1,18 \mathrm{mS} \cdot \mathrm{cm}^{-1}\right)$. Este riego excesivo provocó el encharcamiento de los surcos que se mantuvo durante 2 días posteriores, potenciado además por las precipitaciones acontecidas durante los días 2 y 3 de cultivo, produciéndose elevadas pérdidas de agua por drenaje y dificultando el forzado del sistema radicular, por lo que el riego inicial de plantación podría haber sido bastante inferior si se hubiera llevado a cabo una gestión más óptima del riego.

Desde el punto de vista agronómico y en base a las recomendaciones dadas por Rincón (2005), el segundo riego (riego de arraigue) debería haberse retrasado 2 días más para facilitar un mayor agotamiento del contenido en humedad en los primeros $15 \mathrm{~cm} \mathrm{y}$ forzado del sistema radicular. El riego de arraigue, de 21,41 mm, proporcionado por el regante, también fue bastante superior al aplicado en la parcela experimental, de 11,92 $\mathrm{mm}$, provocando nuevamente movimiento de agua en las capas profundas del suelo y excesivas pérdidas por drenaje. 
A partir del día 7 tras el trasplante, el regante decidió suprimir totalmente el riego hasta el día 27, debido a las precipitaciones acontecidas los días 9, 10, 14 y 15, que supusieron un aporte total de agua de 37,60 mm. No obstante, este periodo de supresión fue demasiado largo, lo que hizo descender el contenido de humedad del suelo a niveles inferiores al máximo agotamiento permisible (PDP) (Fig. 2.6). Aun así, el riego aplicado el día 27 , de $11,03 \mathrm{~mm}$, no fue suficiente para elevar nuevamente el contenido de humedad del suelo a umbrales de capacidad de campo.

El riego de 10,38 $\mathrm{mm}$ aplicado el día 33 tras el trasplante, consiguió elevar el contenido de humedad del suelo en la zona de mayor densidad radicular a valores de capacidad de campo. El día posterior a la aplicación de este riego, tuvo lugar un episodio de precipitación que aportó 5,50 $\mathrm{mm}$ al cultivo, hecho que provocó una nueva supresión del riego por el regante hasta el día 42. En consecuencia, el contenido de humedad se situó nuevamente fuera del intervalo óptimo de humedad, a pesar de los riegos aplicados los días 42 y 46, de 11,37 y 6,83 mm, respectivamente, que también fueron insuficientes. En consecuencia, el contenido de humedad se mantuvo fuera del intervalo óptimo prácticamente desde el día 23 hasta el día 51, principalmente debido a las supresiones de riego llevadas a cabo por el regante, a las precipitaciones, y al gran intervalo entre riegos, situación que podría haber sido evitada aplicando un intervalo entre riegos inferior (1-2 días) con dosis inferiores. A partir del día 51 de cultivo, es cuando el contenido de humedad del suelo se mantiene en umbrales próximos a capacidad de campo.

La Tabla 2.2 muestra las diferencias más significativas entre la parcela patrón y la parcela experimental. El volumen total de riego aplicado en la parcela patrón fue de $156,47 \mathrm{~mm}$ y se obtuvo una producción comercial total de lechuga confeccionada de $21.543 \mathrm{~kg} \cdot \mathrm{ha}^{-1}$. Este volumen aplicado fue un 17,80\% superior al aplicado en la parcela experimental; sin embargo los niveles de humedad del suelo se mantuvieron prácticamente casi todo el ciclo de cultivo fuera del intervalo óptimo de humedad. Este déficit de humedad en el suelo provocó la aparición de quemaduras en los bordes de las hojas más tiernas e interiores de gran cantidad de plantas de lechuga, desorden físiológico conocido como 'tipburn', producido por una deficiente traslocación del calcio en la planta (Sonneveld y Mook, 1983; Napier et al., 2005). La aparición de tipburn produjo una reducción de la producción comercial del 6,93\% respecto a la obtenida en la parcela experimental, principalmente debido al elevado porcentaje de destrío alcanzado 
$(14,82 \%)$. Además, se redujo la productividad del uso del agua en la parcela patrón un $20,99 \%$ respecto a la parcela experimental, situándose en $13,77 \mathrm{~kg} \cdot \mathrm{m}^{-3}$.

Tabla 2.2. Características productivas de las parcelas estudiadas.

\begin{tabular}{lrrrrrr}
\hline \multicolumn{1}{c}{ Parcela } & $\begin{array}{r}\text { Area } \\
(\mathrm{ha})\end{array}$ & $\begin{array}{r}\text { Producción } \\
(\mathrm{kg})\end{array}$ & $\begin{array}{r}\text { Productividad } \\
\left(\mathrm{kg} \cdot \mathrm{ha}^{-1}\right)\end{array}$ & $\begin{array}{r}\text { Descarte } \\
(\%)\end{array}$ & $\begin{array}{r}\text { Riego Total } \\
(\mathrm{mm})\end{array}$ & $\begin{array}{r}\text { Productividad Uso } \\
\text { Agua }\left(\mathrm{kg} \cdot \mathrm{m}^{-3}\right)\end{array}$ \\
\hline Patrón & 4,60 & 99.098 & 21.543 & 14,82 & 156,47 & 13,77 \\
Experimental & 3,70 & 85.640 & 23.146 & 8,56 & 132,83 & 17,43 \\
\hline
\end{tabular}

\section{CONCLUSIONES}

La fotografía digital y su posterior procesamiento informático se han consolidado como sencillas y robustas técnicas para la estimación de la fracción de cobertura vegetal. En este contexto, la aplicación de la metodología específica desarrollada por FernándezPacheco et al. (2014) a un cultivo comercial de lechuga (Lactuca sativa L. cv. 'Little Gem') permitió determinar con éxito las ecuaciones que relacionan $P G C$ con el coeficiente de cultivo $K c$ y estimar así durante todo el ciclo de cultivo su evapotranspiración $E T$, para su posterior empleo en el balance hídrico y programación del riego.

La gestión llevada a cabo permitió obtener en la parcela experimental una productividad de $23.146 \mathrm{~kg} \cdot \mathrm{ha}^{-1}$, un $6,93 \%$ superior a la obtenida en la parcela patrón, donde la programación del riego fue llevada a cabo en base a criterios objetivos y experiencia del agricultor. El consumo de agua por el cultivo en la parcela experimental resultó un 17,80\% inferior al aplicado en la parcela patrón, lo que derivó en mejores resultados de productividad del uso del agua, $17,33 \mathrm{~kg} \cdot \mathrm{m}^{-3}$ en la parcela experimental, frente a los $13,77 \mathrm{~kg} \cdot \mathrm{m}^{-3}$ de la parcela patrón. Como beneficio de la óptima gestión del riego llevada a cabo en la parcela experimental, también se obtuvo un porcentaje de destrío inferior, $8,56 \%$ frente al $14,82 \%$ de la parcela patrón. Esta diferencia en el porcentaje de destrío se debió a la aparición de tipburn en la plantas de la parcela patrón, fisiopatía que no fue detectada en la parcela experimental, al mantenerse en ésta un alto contenido de agua en el suelo, próximo al punto de capacidad de campo.

En resumen, la utilización de la fotografía digital y diversas técnicas de procesamiento informático, como herramientas de apoyo al balance hídrico y a una óptima gestión del riego en cultivos de lechuga, permite obtener mejores rendimientos económicos del cultivo asociados a una mayor productividad y menor consumo de agua de riego, así como la aparición de ciertos desórdenes fisiológicos como tipburn. 


G Model
AGWAT-3975; No. of Pages 10

\section{Digital photography applied to irrigation management of Little Gem lettuce}

\section{Escarabajal-Henarejos ${ }^{a, *}$, J.M. Molina-Martínez ${ }^{a}$, D.G. Fernández-Pacheco ${ }^{\mathrm{b}}$,} F. Cavas-Martínez ${ }^{\text {b }}$, G. García-Mateos

a Research Group in Agromotic Engineering and the Sea, Technical University of Cartagena, Cartagena 30203, Spain ${ }^{\mathrm{b}}$ Graphical Expression Department, Technical University of Cartagena, Cartagena 30202, Spain

c Computer Science and Systems Department, University of Murcia, Murcia 30100, Spain

\section{A R T I C L E I N F O}

\section{Article history:}

Received 15 May 2014

Received in revised form 6 August 2014

Accepted 8 August 2014

Available online $\mathrm{xxx}$

\section{Keywords:}

Irrigation scheduling

Percentage of ground cover

Crop coefficient

Water balance

Image processing

\begin{abstract}
A B S T R A C T
The fundamental principle of adequate irrigation management is to satisfy crop water requirements while optimizing agronomic profits with the lowest possible consumption of water. Based on this idea, new techniques have been incorporated into different irrigation scheduling approaches. Among these techniques, computer processing of digital photographs of vegetation cover has given researchers an opportunity to obtain the crop development parameters that are used to estimate water requirements. The fraction of ground cover, which is obtained by applying classification techniques to digita photographs, is a useful parameter for determining crop water requirements based on the FAO-56 methodology because it is directly related to a crop coefficient. In this research, irrigation scheduling based on the water balance of a 'Little Gem' lettuce crop was carried out using digital photography to estimate water requirements using a crop coefficient. The results were compared with the actual irrigation management of a test plot, which was monitored using soil moisture probes to analyse management deficiencies and to quantify excess irrigation. In sum, a $6.93 \%$ increase in production and a $17.80 \%$ reduction in water consumption compared to the reference plot were achieved.
\end{abstract}

(c) 2014 Elsevier B.V. All rights reserved.

\section{Introduction}

Current agricultural requirements demand a compromise between productivity and sustainability involving the efficient use of production factors and their proper management. The sustainable use of water, which is a valuable resource that is becoming increasingly scarce (Costa et al., 2007), represents one of the main challenges for the future of agriculture, making it necessary to adopt new tools and methodologies that enhance the efficiency of water use while maintaining production levels (Ortuño et al., 2010; Molina-Martínez et al., 2011; Zhang and Kovacs, 2012).

In this context, digital photography and image processing techniques have become essential and appear to be a major source of real-time information about various parameters related to crop development and water status (Blasco et al., 2002; Lorente et al., 2012). These types of tools have already been successfully applied in several agricultural research fields, for instance, in determining

\footnotetext{
* Corresponding author. Tel.: +34 9683259 29; fax: +34 968327031. E-mail addresses: david.escarabajal@gmail.com, davidescarabajal@outlookes (D. Escarabajal-Henarejos)

the colour differences and fertility of corn crops (Ewing and Horton, 1999), evaluating the porosity of windbreak barriers (Kenney, 1987), quantifying the number of flowers on a tree (Adamsen et al. 2000) and estimating the leaf area index of onion crops (Córcoles et al., 2013). Furthermore, its application has extended to other disciplines such as silviculture; for example, Meir et al. (2000) used digital photography to measure the vertical distribution of forest leaf area density, and Brown et al. (2000) estimated the size of the treetops using digital analysis of vertical photographs.

One of the main applications of digital photography for irrigation scheduling relies on the determination of the vegetation cover fraction (Calera et al., 2001). The canopy regulates mass and energy exchanges and controls the behaviour of hydrological processes through the modification of infiltration, runoff and evapotranspiration (Cayrol et al., 2000). The percentage of green cover (PGC) is a biophysical parameter that is used to represent different functions of crop growth and development (Richardson et al., 2001; Walthall et al., 2004; Laliberte et al., 2007).

This PGC enables estimation of the crop water requirements because it is directly related to evapotranspiration $\left(E T_{C}\right)$, which is calculated as a product of the crop coefficient $(K c)$ and the reference evapotranspiration (ETo $)$ (Allen et al., 1998, 2011). Several 
G Mode AGWAT-3975; No. of Pages 10 ARTICLE IN PRESS

authors have achieved satisfactory results relating the PGC with the crop coefficient $K c$ in tomatoes (Hanson and May, 2006), beans (de Medeiros et al., 2001) and onions (López-Urrea et al., 2009). In lettuce, Fernández-Pacheco et al. (2014) developed a new methodology based on digital image processing to estimate the crop coefficient from digital photographs of the vegetation cover. Furthermore, other recent developments have succeeded in relating the fraction of vegetation cover with the root depth (EscarabajalHenarejos et al., 2014). Knowledge about the rooting depth during the course of crop development allows for irrigation schedule optimization based on the soil water content, which enables a water balance that is adapted and restricted to the root absorption area.

This research describes the application of digital photography and image processing techniques as simple and novel tools for estimating the water needs of a lettuce crop (Lactuca sativa L. cv. 'Little Gem'). As a water management technique for horticultural crops, this technique permits crop irrigation scheduling based on computerized water balance components. The results of this research have been compared with existing irrigation management based on objective criteria from the person responsible for irrigation.

The rest of this paper is organized as follows. In Section 2, the proposed methodology is described in detail. Section 3 presents and discusses the experimental results and comparisons. Finally, Section 4 draws the main conclusions.

\section{Materials and methods}

\subsection{Experimental plot}

The experiment was carried out on a commercial lettuce crop (Lactuca sativa L. cv. 'Little Gem') located in San Javier (latitude $37^{\circ} 47^{\prime} 04^{\prime \prime} \mathrm{N}$, longitude $0^{\circ} 49^{\prime} 34^{\prime \prime} \mathrm{W}$ and altitude $15 \mathrm{~m}$ ) in the province of Murcia, Spain. The plot has an approximate area of 8.3 ha. Lettuce seedlings were obtained separately from a seedbed and transplanted with a planting density of 16.5 plants. $\mathrm{m}^{-2}$.

The experiment was conducted from October to December of 2011-2013. Methodology proposed by Fernández-Pacheco et al. (2014) was used in 2011 to obtain and calibrate equations relating the percentage of green cover, the plant height and the $K c$ parameter of the studied crop (Fig. 1). These equations were validated during the subsequent 2 years (2012 and 2013). Furthermore, during the 2013 season, the obtained equations were applied to manage and schedule crop irrigation, which was performed using an automated drip irrigation system and water from the TajoSegura transfer, which has an electrical conductivity of $2.17 \mathrm{dS} \mathrm{m}^{-1}$ and a $\mathrm{pH}$ of 7.85 .

To obtain the same pluviometry, an emitting pipe was put in place for each paired line of plants with drippers every $30 \mathrm{~cm}$; a flow rate of $2 \mathrm{~L} \mathrm{~h}^{-1}$ of unitary discharge was used for single paired lines and $1 \mathrm{Lh}^{-1}$ unitary discharge was used for double paired lines. The soil of the plot is classified as "Calcic Petrocalcids" and has an average depth of approximately $40 \mathrm{~cm}$, which is limited by the existence of a petrocalcic horizon that is more or less fragmented. The predominant texture is sandy clay-loam (sand: $55.25 \%$, silt: $15.00 \%$ and clay: $29.75 \%$ ) with a soil water content at the field capacity point (FCP) of $25 \%$ and at the permanent wilting point (PWP) of 17\% (Saxton and Rawls, 2006).

The climate of the zone is Mediterranean subdesert. During the 3 years of the experiment, the temperatures measured in the plot were very similar. An average maximum temperature of $22.2^{\circ} \mathrm{C}$ $21.1^{\circ} \mathrm{C}$ and $22.7^{\circ} \mathrm{C}$ and an average minimum of $11.1^{\circ} \mathrm{C}, 10.9{ }^{\circ} \mathrm{C}$ and $10.3^{\circ} \mathrm{C}$, respectively, were registered in the plots for the 3 years, creating an average temperature during the cropping season of $15.3^{\circ} \mathrm{C}$. During the 2011 season, a total cumulative rainfall of $137.80 \mathrm{~mm}$ was observed. Nevertheless, this value decreased by almost half during the following two seasons in which rainfall was sparse and unevenly distributed, with a total cumulative volume of $75.12 \mathrm{~mm}$ in 2012 and $62.30 \mathrm{~mm}$ in 2013, because these were two exceptionally dry years. The precipitation levels were recorded using a RAIN-O-MATIC (Campbell Scientific, Logan, UT, USA) pluviometer, which is part of a weather station placed inside the experimental plot.

\subsection{Irrigation management}

During the 2013 planting, and in order to compare the irrigation management of the lettuce crop, the plot was divided into two subplots; each of these corresponded to an irrigation sector to allow for separate watering of each. The same soil conditions and planting density were maintained in both subplots. However, the irrigation was managed differently to establish irrigation criteria and provide further advice to the irrigator.

One subplot, termed the 'reference plot', had an area of 4.6 ha, and watering was performed based on objective criteria and the experience of the irrigator of the farm without interference in the irrigation decision-making. As a first step, transplant irrigation was performed, which was followed by a water suppression period to force the development of the root system. The farmer irrigated twice per week, varying the value based on visual aspects of the terrain and the plant and on the presence of rainfall or strong wind. Crop monitoring was done by measuring the soil moisture content. For that purpose, $\mathrm{ECH}_{2} \mathrm{O}$ equipment was installed (Decagon Devices Inc., WA, USA) that was composed of three high speed capacitive frequency domain reflectometry (FDR) sensors, model $10 \mathrm{HS}$, installed at 15, 30 and $45 \mathrm{~cm}$ depth. Data from these sensors were recorded hourly and stored by a datalogger Em50G (Decagon Devices Inc., WA, USA).

In the other 3.7 ha subplot, termed the 'experimental plot', the irrigation was managed by setting the water balance in the root zone to determine the soil moisture content and the optimal timing of irrigation. Because the crop was irrigated by a drip irrigation system, this allowed for frequent discharges of small amounts of water, resulting in high yields and water use efficiency; furthermore, this method obtained maximum production when soil moisture was high and continuous production throughout the vegetative stage of the crop (Bert and Honma, 1975; Sutton and Merit, 1993; Rincón, 2001). This allowed for maintenance of the soil moisture content close to the field capacity point during the entire cropping season of the study (Salter and Goode, 1967).

\subsection{Soil water balance}

The irrigation needs of the crop placed on the experimental plot were estimated from the water balance in the root zone. The soil water balance in the root zone is given by the following:

$\left(\theta_{t}-\theta_{t-1}\right) z=P+I-D-E T-R$

where $\theta_{t-1}$ and $\theta_{t}$ are the initial and final depth-averaged soil water content of the root zone at one time step, respectively $\left(\mathrm{cm}^{3} \mathrm{~cm}^{-3}\right)$, $z$ is the measured root zone depth $(\mathrm{cm}), P$ is the rainfall $(\mathrm{mm}), I$ is the irrigation $(\mathrm{mm}), D$ is the drainage from the root zone $(\mathrm{mm}), E T$ is the actual evapotranspiration ( $\mathrm{mm}$ ) and $R$ is the surface runoff ( $\mathrm{mm})$; however, this last variable was considered to be negligible in the case of localized irrigation.

Crop evapotranspiration (ET) was estimated as the product of the reference evapotranspiration $\left(E T_{0}\right)$ and the crop coefficient $(K c)$. The $E T_{0}$ was calculated using the Penman-Monteith method (Allen et al., 1998), and all of the required meteorological data were collected using a weather station that was placed within the reference crop and very close to the experimental plot. The station was equipped with a datalogger (CR10X, 


\section{ARTICLEE IN PRIESS}

D. Escarabajal-Henarejos et al. / Agricultural Water Management xxx (2014) xxx- $x x x$

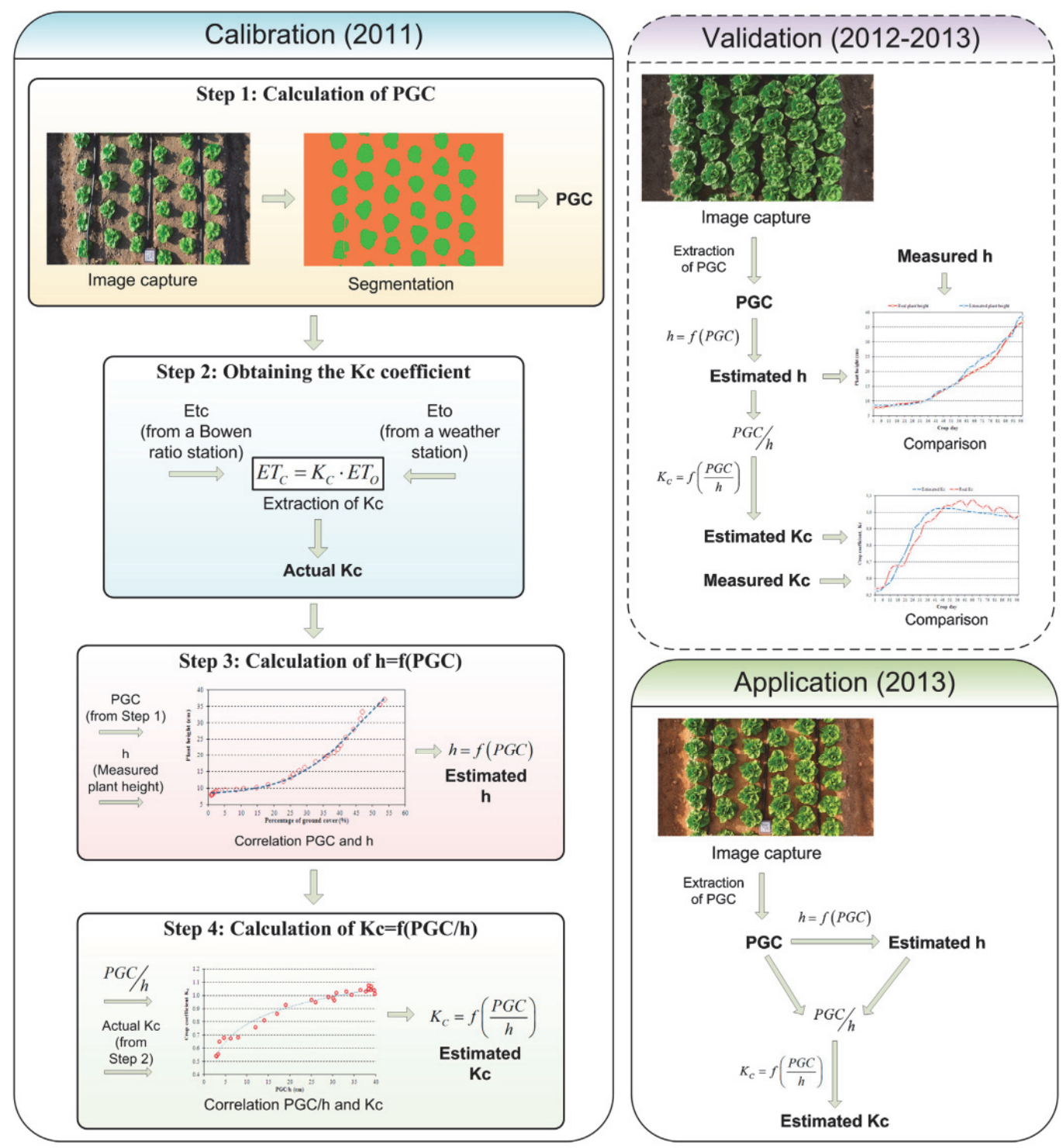

Fig. 1. The applied methodology scheme.

Campbell Scientific, Logan, UT, USA) and sensors measuring the temperature and relative air humidity (MP100 probe, Campbel Scientific, Logan, UT, USA), solar radiation (CM14 pyranometer KIPP\&ZONEN, Delft, Holland), wind speed and direction (A100R anemometer and W200P windvane, Vector Instruments Ltd., UK), and rainfall (ARG100 pluviometer, Campbell Scientific, Logan, UT). The temperature and humidity probe was placed $1.5 \mathrm{~m}$ above ground level, whereas the wind sensors were located $2.0 \mathrm{~m}$ high.

The estimation of the crop coefficients $K c$ was carried out using methodology (Fig. 1) proposed by Fernández-Pacheco et al. (2014). This approach provided, as a first step, the mathematical relationship between the crop height $(h)$ and the percentage of ground cover (PGC) obtained by computer processing of digital images of the crop canopy. The initial result was an equation that enabled the estimation of the crop height $\left(h_{\text {est }}\right)$ from the PGC. Then, the method calculated an intermediate parameter $\left(P G C / h_{\mathrm{est}}\right)$, which is related to the crop coefficient $K c$.

The methodology used was previously calibrated for the study crop (Lactuca sativa L. cv. 'Little Gem') in the same plot, under similar climatic conditions and in the same crop season from October to December 2011 and was subsequently used and validated in 2012 and 2013. Therefore, the four sampling areas were established to measure the evolution of the percentage of ground cover; therefore, vertical photographs provided computation analysis of the canopy with a compact digital camera (Coolpix S3300, 

G Model
AGWAT-3975; No. of Pages 10

4

D. Escarabajal-Henarejos et al. / Agricultural Water Management $x x x(2014) x x x-x x x$

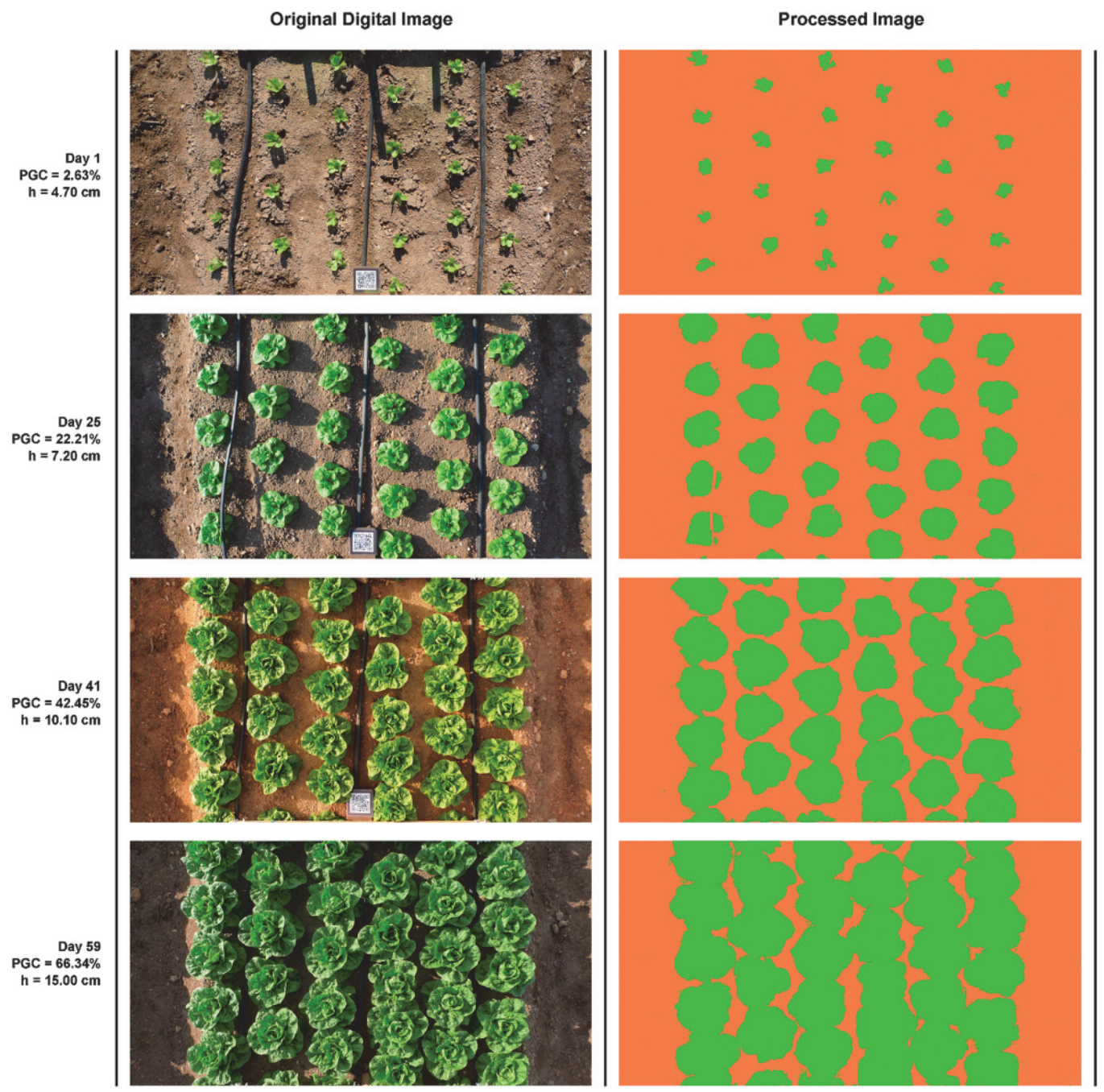

Fig. 2. Sample results obtained using image processing software.

Nikon, Japan) equipped with a charge-coupled device (CCD) sensor (resolution 16.0 megapixels; focal length $27.6 \mathrm{~mm}$ ) that was mounted on a tripod at a fixed height at $1.40 \mathrm{~m}$ above ground level. To match the percentage of ground covered with the vegetation and the fraction of the area shaded by the plant, photographs were taken at solar noon. These photographs were later digitally processed using ENVI ${ }^{\circledR}$ (Environment for Visualizing Images) (Research System Inc., Boulder, CO, USA), which enables researchers to obtain: (i) a segmentation of the image (see Fig. 2) to discriminate between soil (beige) and vegetation (green), and (ii) the number of pixels corresponding to vegetation $(\mathrm{V})$, soil $(\mathrm{S})$ and total $(\mathrm{T})$; therefore, the percentage of ground cover is defined as the $\mathrm{V} / \mathrm{T}$ ratio.

Furthermore, the crop height was measured and the mathematical expression relating the $h$ and the PGC was obtained. Finally, the second equation in the methods proposed by Fernández-Pacheco et al. (2014) that allows for the estimation of the $K c$ from the ratio
$P G C / h_{\text {est }}$, the coefficients $K c$ were determined on-site by applying the Bowen Ratio-Energy Balance method (BREB) (Bowen, 1926), and these were related to the $P G C / h_{\text {est. }}$ The equations obtained from the calibration conducted in 2011 were used in 2012 and 2013 to obtain the crop coefficients $K c$ for determining the $E T$.

\subsection{Irrigation scheduling}

To determine the optimal timing of irrigation and to manage accordingly, the upper and lower limits of the soil water content (SWC) were established. As an upper limit, the value of the soil moisture content at the field capacity point was considered $\left(\theta_{\mathrm{FCP}}\right)$. The lower limit indicated the irrigation start time and was established by the soil moisture content at a maximum allowable depletion $\left(\theta_{\text {NAP }}\right)$. Below this moisture content $\theta_{\text {NAP, }}$, the root system has more difficulty extracting water, resulting in a decrease in the transpiration and, consequently, production losses. The

Please cite this article in press as: Escarabajal-Henarejos, D., et al., Digital photography applied to irrigation management of Little Gem lettuce. Agric. Water Manage. (2014), http://dx.doi.org/10.1016/j.agwat.2014.08.009 


\section{G Model}

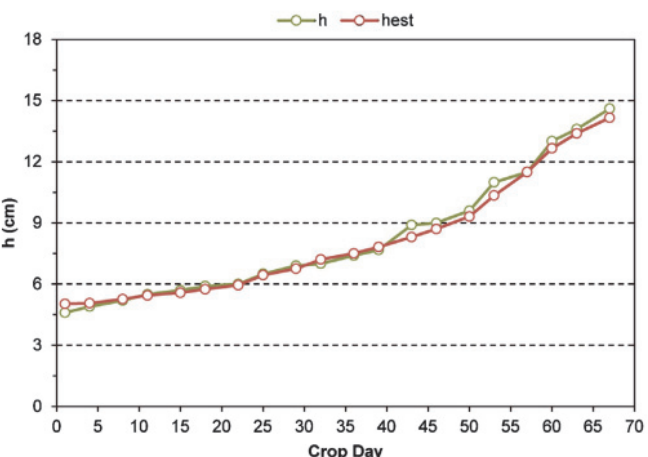

a)

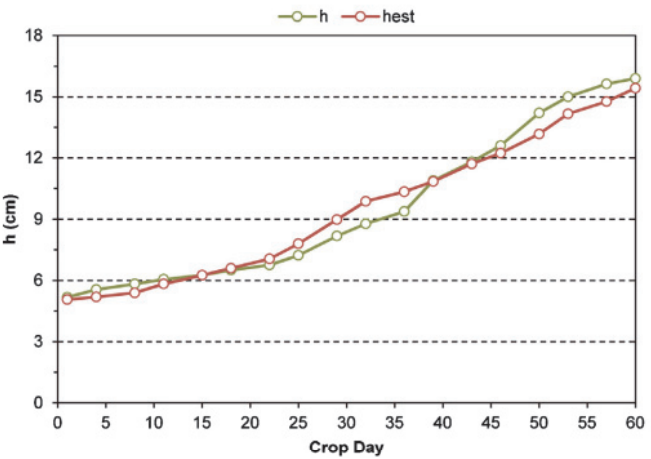

c)

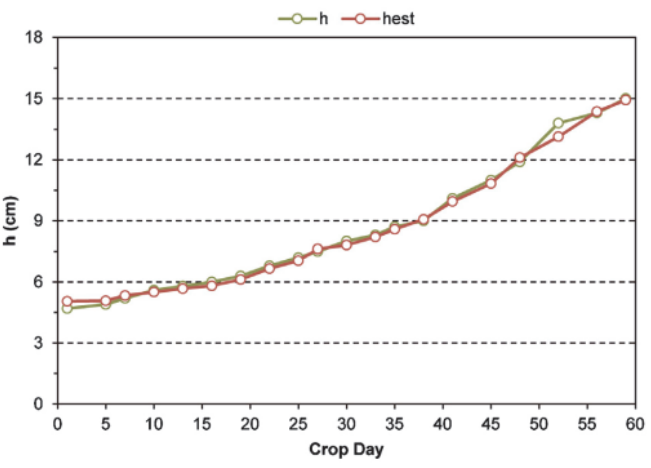

e)

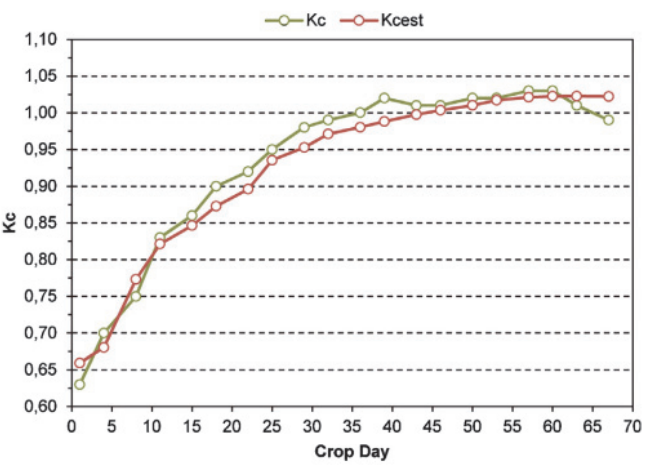

b)

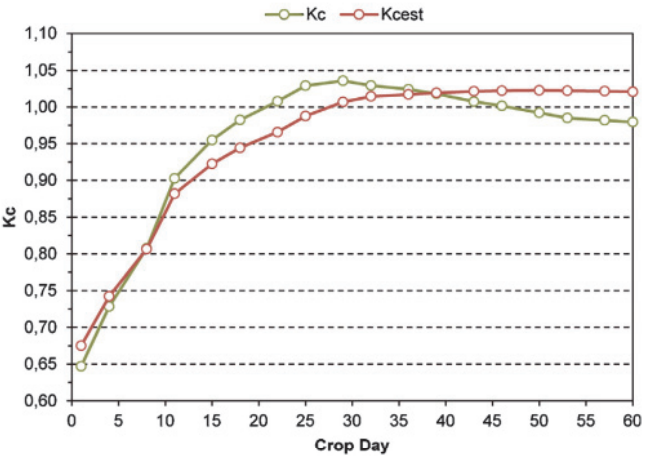

d)

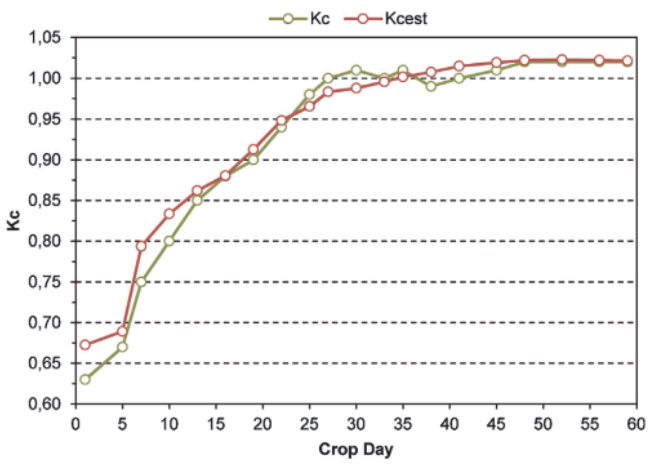

f)

Fig. 3. Comparison of the actual and estimated plant heights and $K c$ values during: (a-b) the 2011 calibration year (equations applying the methodology proposed by Fernández-Pacheco et al. (2014) in Little Gem lettuce crop were obtained), (c-d) the 2012 validation year, and (e-f) the 2013 validation year.

computation of $\theta_{\mathrm{NAP}}$ is based on the consideration of a permissible fraction of depletion ( $f$ ) (Doorenbos and Pruitt, 1977), which marks the range between the upper and lower limits and therefore the frequency of irrigation application. The soil moisture value corresponding to the lower limit was determined using the following equation:

$\theta_{\mathrm{NAP}}=\theta_{\mathrm{FCP}}-f\left(\theta_{\mathrm{FCP}}-\theta_{\mathrm{PWP}}\right)$ where $\theta_{\text {NAP }}$ represents the lower limit or soil moisture content at the maximum allowable depletion (\%), $\theta_{\mathrm{FCP}}$ is the soil moisture content at field capacity point (\%), $\theta_{\text {PWP }}$ is the soil moisture content at the permanent wilting point (\%), and $f$ represents the fraction of allowable depletion. With the aim of reducing the direct evaporation and increasing plant transpiration, a fraction of allowable depletion of $f=0.15$ was considered (Rincón, 2001), maintaining a high moisture content in the surface layers of the soil.

Please cite this article in press as: Escarabajal-Henarejos, D., et al., Digital photography applied to irrigation management of Little Gem lettuce. Agric. Water Manage. (2014), http://dx.doi.org/10.1016/j.agwat.2014.08.009 


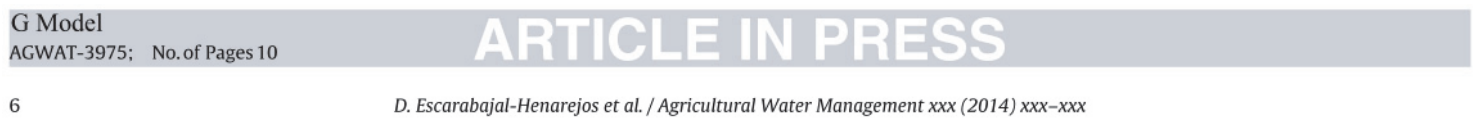

\section{Results and discussion}

\subsection{Method of Kc calibration}

During this study, the FAO-56 methodology (Allen et al., 1998) was applied to determine the crop evapotranspiration (ET). This methodology determines the $E T$ as the product of a reference evapotranspiration $\left(E T_{0}\right)$ and a crop coefficient $(K c)$. During the study, the daily crop coefficients $(K c)$ were calculated using the equations obtained from October to December 2011 by applying the methods proposed by Fernández-Pacheco et al. (2014). Initially, an equation that related the values of the PGC, which were obtained by computerized processing of digital images of the vegetation cover and crop height $h$, were obtained. For this experiment, several approximation functions were analysed, including the double sigmoid, logistic, Gompertz and monomolecular functions. The optimal results were obtained using a monomolecular function (Eq. (3)), where $y=h(\mathrm{~cm}), x=P G C(\%), a=4.484$ and $b=0.017$.

$y=a \times e^{b x}$

To evaluate the performance of the equation, the measured plant height and the plant height estimated using Eq. (3) were compared (Fig. 3a). A linear regression analysis was also carried out, yielding a slope of the linear regression line that was very similar to 1 (0.944) and a squared correlation coefficient of 0.995 (Table 1 ). The obtained average root mean square error (RMSE) was 0.065 , demonstrating that the difference between the actual values and the values predicted by the model was minimal.

Finally, the relationship between the $P G C / h_{\text {est }}$ parameter and the crop coefficient $K_{C}$ permitted to obtain a logarithmic function that correlated them (Eq. (4)), where $y=K c, x=P G C / h_{\text {est }}\left(\% \cdot \mathrm{cm}^{-1}\right)$, $a=0.163$ and $b=0.779$.

$y=a \times \ln (x)+b$

The $K c$ values estimated using this equation were compared with the actual $K c$ values obtained with application of the BREB method (Fig. 3b); a linear regression analysis was performed (Table 1 ), yielding a linear regression slope line very similar to 1 (0.949) and a squared correlation coefficient of 0.977 . The obtained value of the RMSE was 0.005 .

The first validation was carried out over 60 days from October 2012 to December 2012. During this validation period, two comparisons were undertaken. First, the relationship between the estimated plant height and the measured height was analysed, and a good fit was obtained (Fig. 3c). A linear regression analysis was also carried out, yielding a squared correlation coefficient of 0.977 and a linear regression slope line of 0.920 . In this case, the obtained RMSE value was 0.141 (Table 1). Second, the estimated and actual values of the $K c$ were compared, and a strong agreement was observed between the measured data and the modelled $K c$ values throughout the growth cycle (Fig. 3d). This comparison was also accompanied by a linear regression analysis, which yielded a squared correlation coefficient of 0.929 and a linear regression slope line of 0.929 (Table 1 ). In this case, an RMSE of 0.007 was obtained.

The second validation was undertaken over 59 days from October 2013 to December 2013. Fig. 3e compares the measured plant heights and the estimated plant heights, yielding a squared correlation coefficient of 0.996 , a slope of the linear regression line of 0.979 and an RMSE of 0.048 (Table 1). Finally, Fig. 3f presents the relationship between the estimated $K c$ values and the actual values, yielding a linear regression slope line of 0.890 , a squared correlation coefficient of 0.989 and an RMSE of 0.005 (Table 1).

The crop coefficients $K c$ obtained during 2013 using the methodology proposed by Fernández-Pacheco et al. (2014) were used to estimate the crop ET. This $K c$ value increased linearly during the

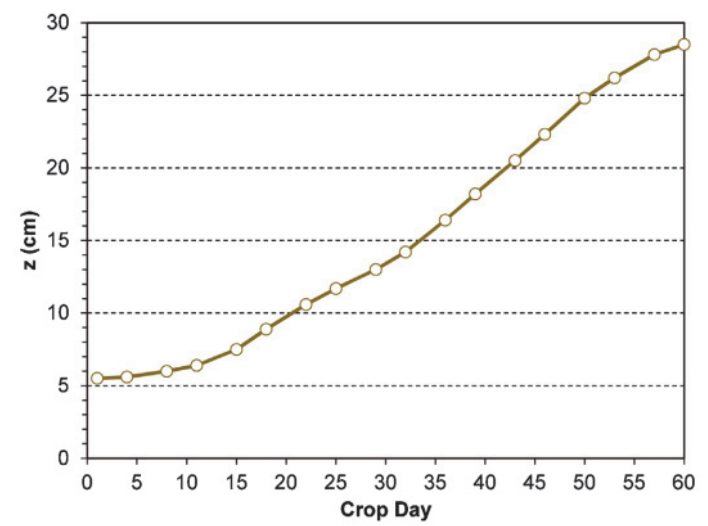

Fig. 4. Evolution of the root depth during the crop cycle for the Little Gem lettuce crop.

first 35 days after transplanting (Fig. 3 f), ranging from 0.67 in the first days to 1.02 in the hearting phase and until harvest, which are somewhat similar to the values obtained by Rincón and Sáez (1997) for 'Iceberg' lettuce and by Fernández-Pacheco et al. (2014) for lettuce (Lactuca sativa L. cv. 'Hierro'); these are very similar varieties.

\subsection{Water balance and irrigation scheduling in the experimental} plot

The ET values obtained during 2013 permitted establishment of crop irrigation scheduling in the experimental plot using water balance management in the crop root zone, which enabled determination of the soil water content (SWC) and irrigation application timing. To adjust the water balance to the soil profile inhabited by the root system of the plant, the root depth of the crop $(z)$ was directly measured in the ground on each sample day. Fig. 4 shows the evolution of the root depth over the cropping season. This depth increases linearly from $6 \mathrm{~cm}$ after transplanting to $29 \mathrm{~cm}$ after the harvest, which are the values expected under drip irrigation and clay-loam soil conditions (Rincón et al., 1991); however, the highest root density is concentrated between 10 and $25 \mathrm{~cm}$.

For the calculation of the water balance, the recommendations given by Rincón (2005), which establish certain irrigation recommendations at given crop development times, were followed. The water balance is shown in Table 2. Irrigation to hold the SWC near the field capacity point $(\mathrm{FCP}=25 \%$ ) during the entire growing season (Salter and Goode, 1967) were scheduled, preventing the SWC from dropping below the maximum permissible depletion percentage ( $\mathrm{PDP}=23.8 \%$ ) (Fig. 5).

An initial irrigation was performed so that all of the seedlings were sufficiently watered and fixed to the ground. At the beginning of the cropping season, the electric conductivity of the soil saturation extract (ECe) was $1.18 \mathrm{dS} \mathrm{m}^{-1}$, which was below the tolerance threshold of lettuce at a salinity of $1.30 \mathrm{dS} \mathrm{m}^{-1}$ (Ayers and Westcot, 1987). Therefore, the initial salinity of the soil was low enough to be tolerated by the crop. Therefore, the supply of water used for irrigating the field did not induce initial leaching of salts and was simply estimated to increase the initial water content of the soil (10\%) to the field capacity point $(\mathrm{FCP}=25 \%$ ). The crop watering depends on the type and initial moisture of the soil; in this case, $23.84 \mathrm{~mm}$ were applied, which falls within the range of 20 to $30 \mathrm{~mm}$ recommended by Rincón (2005). 
G Model

AGWAT-3975; No. of Pages 10 ARTICLEE IN PRESS

Table 1

Statistical data from a linear regression analysis performed to compare the estimated vs. actual plant heights and the estimated vs. actual crop coefficients $K c$ during the methodology calibration.

\begin{tabular}{|c|c|c|c|c|c|c|c|}
\hline Figure number & $X$ parameter & $Y$ parameter & Slope & Interception & $R^{2}$ & RMSE & Sample size \\
\hline 1a & Actual plant height & Estimated plant height & 0.944 & -0.033 & 0.995 & 0.065 & 20 \\
\hline $1 \mathrm{~b}$ & Actual crop coefficient & Estimated crop coefficient & 0.949 & 0.039 & 0.977 & 0.005 & 20 \\
\hline $1 \mathrm{c}$ & Actual plant height & Estimated plant height & 0.920 & 0.700 & 0.977 & 0.141 & 18 \\
\hline $1 \mathrm{~d}$ & Actual crop coefficient & Estimated crop coefficient & 0.929 & 0.067 & 0.929 & 0.007 & 18 \\
\hline $1 \mathrm{e}$ & Actual plant height & Estimated plant height & 0.979 & -0.086 & 0.996 & 0.048 & 20 \\
\hline if & Actual crop coefficient & Estimated crop coefficient & 0.890 & -0.111 & 0.989 & 0.005 & 20 \\
\hline
\end{tabular}

Table 2

Water balance in the root zone $(\mathrm{mm})$.

\begin{tabular}{|c|c|c|c|c|c|c|}
\hline Crop day & Reference evapotranspiration & Irrigation & Precipitation & Drainage & Crop evapotranspiration & Crop coefficient \\
\hline 1 & 1.92 & 23.84 & 0 & 10.34 & 1.18 & 0.67 \\
\hline 2 & 1.39 & 0 & 6.2 & 5.34 & 0.86 & 0.68 \\
\hline 3 & 1.92 & 0 & 2.5 & 1.3 & 1.2 & 0.68 \\
\hline 4 & 1.8 & 0 & 0 & 0 & 1.13 & 0.69 \\
\hline 5 & 1.73 & 0 & 0 & 0 & 1.1 & 0.69 \\
\hline 6 & 1.37 & 0 & 0 & 0 & 0.93 & 0.74 \\
\hline 7 & 1.59 & 11.92 & 0 & 5.15 & 1.16 & 0.79 \\
\hline 8 & 2.37 & 0 & 0 & 0 & 1.75 & 0.8 \\
\hline 9 & 1.1 & 0 & 2.9 & 0.32 & 0.83 & 0.82 \\
\hline 10 & 1.49 & 0 & 8.2 & 7.06 & 1.14 & 0.83 \\
\hline 11 & 1.24 & 0 & 0 & 0 & 0.96 & 0.84 \\
\hline 12 & 0.86 & 0 & 0 & 0 & 0.67 & 0.85 \\
\hline 13 & 1.41 & 0 & 0 & 0 & 1.12 & 0.86 \\
\hline 14 & 0.88 & 0 & 13.3 & 4.48 & 0.7 & 0.87 \\
\hline 15 & 1.37 & 0 & 13.2 & 12.1 & 1.1 & 0.87 \\
\hline 16 & 1.31 & 0 & 5.2 & 4.14 & 1.06 & 0.88 \\
\hline 17 & 1.29 & 0 & 1 & 0 & 1.06 & 0.89 \\
\hline 18 & 1.33 & 0 & 0 & 0 & 1.1 & 0.9 \\
\hline 19 & 1.02 & 0 & 0.2 & 0 & 0.85 & 0.91 \\
\hline 20 & 1.19 & 3.36 & 0 & 0.54 & 1.01 & 0.92 \\
\hline 21 & 0.81 & 13.35 & 0 & 2.15 & 0.7 & 0.94 \\
\hline 22 & 1.22 & 0 & 0 & 0 & 1.07 & 0.95 \\
\hline 23 & 1.1 & 0 & 0 & 0 & 0.97 & 0.96 \\
\hline 24 & 1 & 3.48 & 0 & 0.56 & 0.89 & 0.96 \\
\hline 25 & 1.15 & 0 & 0 & 0 & 1.03 & 0.97 \\
\hline 26 & 1.05 & 0 & 0 & 0 & 0.94 & 0.98 \\
\hline 27 & 0.92 & 3.33 & 0 & 0.54 & 0.83 & 0.98 \\
\hline 28 & 0.89 & 10.97 & 0 & 1.77 & 0.81 & 0.98 \\
\hline 29 & 0.85 & 0 & 0 & 0 & 0.77 & 0.99 \\
\hline 30 & 1.57 & 0 & 4.1 & 1.9 & 1.43 & 0.99 \\
\hline 31 & 2.2 & 0 & 0 & 0 & 2.01 & 0.99 \\
\hline 32 & 2.35 & 4.97 & 0 & 0.8 & 2.15 & 1 \\
\hline 33 & 1.24 & 0 & 0 & 0 & 1.14 & 1 \\
\hline 34 & 1.24 & 0 & 5.5 & 3.22 & 1.14 & 1 \\
\hline 35 & 1.29 & 16.85 & 0 & 2.72 & 1.19 & 1 \\
\hline 36 & 1.35 & 0 & 0 & 0 & 1.25 & 1 \\
\hline 37 & 1.32 & 0 & 0 & 0 & 1.13 & 1.01 \\
\hline 38 & 1.27 & 0 & 0 & 0 & 1.18 & 1.01 \\
\hline 39 & 1.4 & 5.79 & 0 & 0.93 & 1.3 & 1.01 \\
\hline 40 & 1.02 & 0 & 0 & 0 & 0.95 & 1.01 \\
\hline 41 & 1.86 & 0 & 0 & 0 & 1.73 & 1.01 \\
\hline 42 & 0.89 & 7.1 & 0 & 1.14 & 0.83 & 1.01 \\
\hline 43 & 1.08 & 0 & 0 & 0 & 1.01 & 1.02 \\
\hline 44 & 0.87 & 0 & 0 & 0 & 0.81 & 1.02 \\
\hline 45 & 0.8 & 0 & 0 & 0 & 0.75 & 1.02 \\
\hline 46 & 0.81 & 3.97 & 0 & 0.64 & 0.76 & 1.02 \\
\hline 47 & 0.96 & 0 & 0 & 0 & 0.9 & 1.02 \\
\hline 48 & 1.05 & 0 & 0 & 0 & 0.99 & 1.02 \\
\hline 49 & 0.91 & 7.86 & 0 & 1.27 & 0.85 & 1.02 \\
\hline 50 & 0.81 & 0 & 0 & 0 & 0.76 & 1.02 \\
\hline
\end{tabular}

During the first days of crop growth, it is good practice to force the plant to develop an extensive and vigorous root system to enhance water and nutrient absorption from the soil; in this way, during the period of greatest extractions, absorption is carried out without restriction (Rincón, 2005). Forcing the root system expansion was achieved by submitting the plant to moderate water stress. Accordingly, the second irrigation was not applied until 6 days after transplanting, which decreased the SWC to $20.9 \%$, a value that is justified by forcing the root system expansion. On the sixth day, a second watering of $11.92 \mathrm{~mm}$, called the "grow-up irrigation", was applied. The aim of this irrigation was to ensure the final establishment of the seedlings.

From the sixth crop day, irrigation was scheduled and executed to maintain the SWC at values near the FCP (Fig. 5); therefore, the irrigation intervals did not exceed 3-4 days. The crop cycle was extended to 59 days after transplanting, during which time the total ET of the crop was $61.64 \mathrm{~mm}$. The water applied for irrigation subsequent to the grow-up irrigation was $97.07 \mathrm{~mm}$, and water 


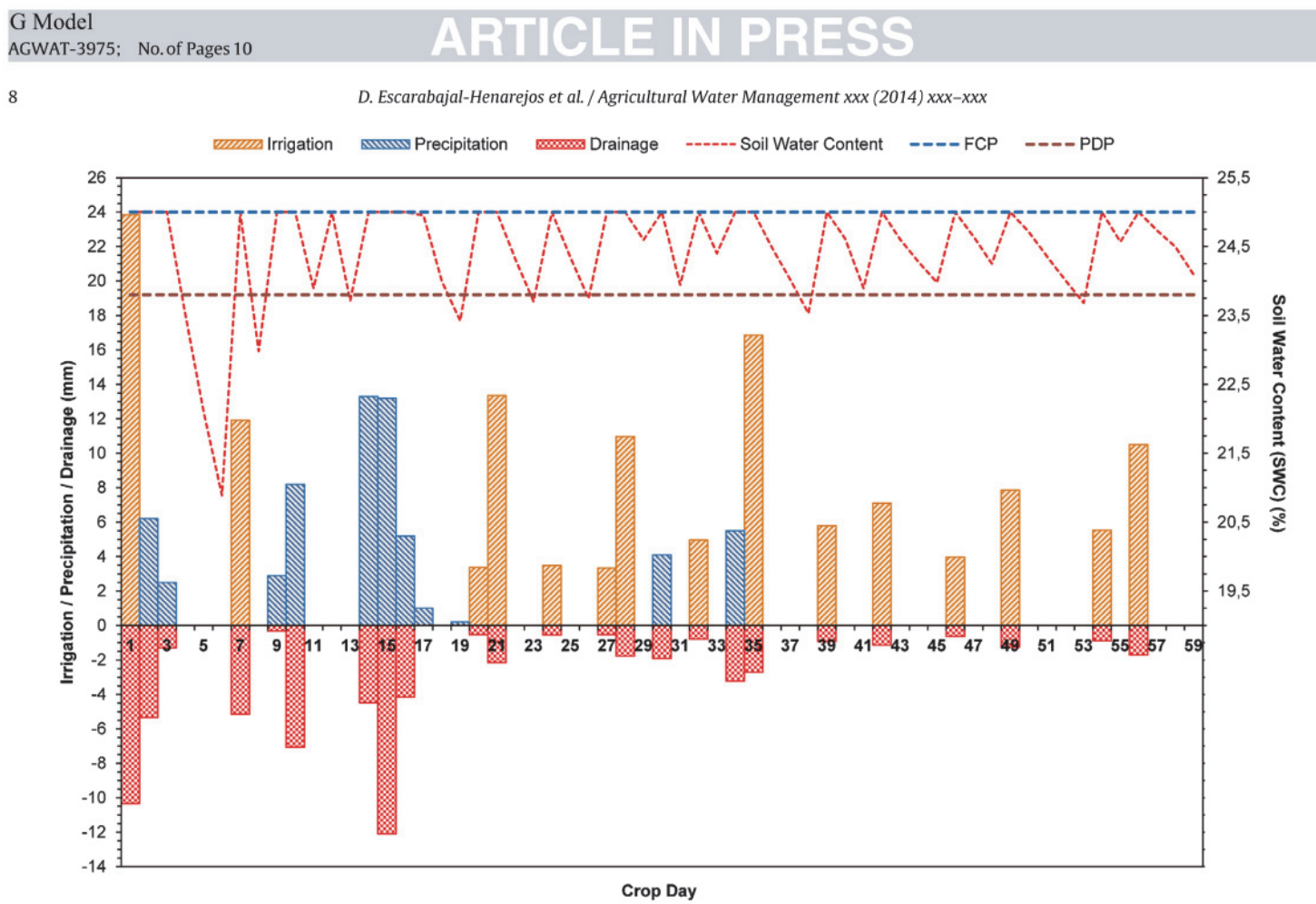

Fig. 5. Components of the calculated water soil balance and evolution of the soil water content in the root zone for the Little Gem lettuce crop placed in the 'experimental plot'.

provided by rainfall was $62.30 \mathrm{~mm}$, of which $84.6 \%$ occurred during the slow growth phase and $15.4 \%$ occurred during the hearting phase (Table 2). The total volume of irrigation applied to the experimental plot was $132.83 \mathrm{~mm}$, generating a total commercial product of $23.146 \mathrm{~kg} \mathrm{ha}^{-1}$ of processed lettuce with a low percentage of discard (8.56\%). The productivity of the water usage was $17.43 \mathrm{~kg} \mathrm{~m}^{-3}$.

\subsection{Irrigation scheduling assessment in the reference plot}

Irrigation was managed in the reference plot by the irrigator of the farm based on objective criteria and his own experience. During the study, the soil moisture content values at a depth of 15 , 30 and $45 \mathrm{~cm}$ were registered and assessed further. In this plot, the root depth of the crop was not considered; instead, the reference values were obtained from the experimental plot. Due to the root depth of the crop did not exceed $15 \mathrm{~cm}$ until day 30 (Fig. 4), more attention was paid to the values of the SWC at $15 \mathrm{~cm}$ depth $\left(\theta_{15}\right)$ during this period (Fig. 6), which focused on the movement of water beneath the first $15 \mathrm{~cm}$ of the soil drained. From day 30, the root depth exceeded $15 \mathrm{~cm}$ and eventually reached $29 \mathrm{~cm}$ during the harvest; the SWC at $30 \mathrm{~cm}$ depth $\left(\theta_{30}\right)$ was also considered (Fig. 6) because the root density was mostly concentrated between 10 and $25 \mathrm{~cm}$. Throughout the cropping season, the values of the SWC at a $45 \mathrm{~cm}$ depth did not represent water availability for the crops, but rather water movement into deeper layers (i.e., drainage).

Fig. 6 shows the evolution of the SWC in the three soil profiles considered in the reference plot, as well as the water inputs from irrigation and rainfall during the cropping season. The initial irrigation applied by the irrigator on the reference plot was $56.89 \mathrm{~mm}$, which was $33.05 \mathrm{~mm}$ higher than that applied in the experimental plot. This initial irrigation was excessive for raising the SWC at the field capacity point (FCP) due to the small requirements of soil salt leaching, which was denoted by its low
EC $\left(1.18 \mathrm{dS} \mathrm{m}^{-1}\right)$. This excessive irrigation caused flooding of the grooves during the 2 subsequent days, which was further aggravated by the precipitation that took place during the 2 nd and 3rd days of the season. This caused high water losses due to drainage and hindered the root system expansion. Therefore, the initial irrigation during planting could have been much lower if a more efficient irrigation management approach had been carried out.

From an agricultural point of view, and based on the recommendations given by Rincón (2005), the second irrigation (grow-up irrigation) should have been delayed by 2 more days to facilitate the further depletion of the SWC in the first $15 \mathrm{~cm}$ and to force the root system to expand. The grow-up irrigation of $21.41 \mathrm{~mm}$ provided by the irrigator was also considerably higher than that applied to the experimental plot (of $11.92 \mathrm{~mm}$ ); this excess caused the movement of water into deeper soil layers and excessive drainage losses.

From day 7 after transplanting, the irrigator decided to completely halt irrigation until day 27 because rainfall on days 9,10 14 and 15 provided a total water supply of $37.60 \mathrm{~mm}$. Nevertheless, this irrigation suppression period was too long, which lowered the SWC to levels below the maximum allowable depletion (PDP) (Fig. 6). Even so, the irrigation applied on day 27, of $11.03 \mathrm{~mm}$, was not enough to raise the SWC back to the field capacity point.

Irrigation of $10.38 \mathrm{~mm}$ applied on day 33 managed to raise the SWC in the area of the highest root density to field capacity values. The day after the application of the irrigation, a rainfall of $5.50 \mathrm{~mm}$ occurred, which caused a new suppression of irrigation by the irrigator until day 42 . Consequently, the SWC did not reach the optimal range of moisture, despite the insufficient irrigation applied on days 42 and 46 of 11.37 and $6.83 \mathrm{~mm}$, respectively. Therefore, the SWC remained outside the optimal range from almost day 23 to day 51 mainly because of irrigation suppression undertaken by the irrigator, precipitation events, and the large interval between irrigations, which could have been avoided with shorter irrigation intervals 
G Model

AGWAT-3975; No. of Pages 10

\section{ARTICLE IN PRESS}

D. Escarabajal-Henarejos et al. / Agricultural Water Management xxx (2014) $x x x-x x x$

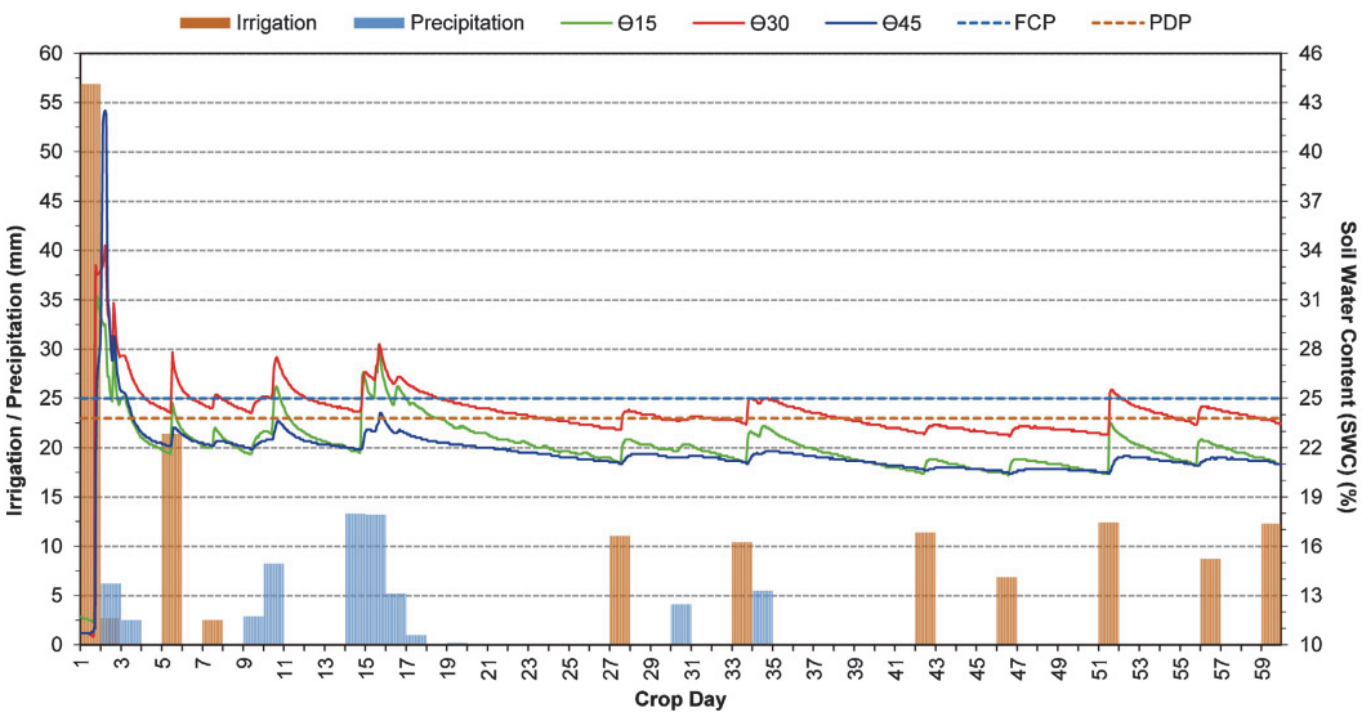

Fig. 6. Irrigation, precipitation events and soil water content at 15,30 and $45 \mathrm{~cm}$ depth measured by FDR probes for the Little Gem lettuce crop placed in the 'reference plot'.

Table 3

Production characteristics of the studied plots.

\begin{tabular}{|c|c|c|c|c|c|c|}
\hline Plot & Area (ha) & Production $(\mathrm{kg})$ & Productivity $\left(\mathrm{kg} \mathrm{ha}^{-1}\right)$ & Discard (\%) & Total irrigation $(\mathrm{mm})$ & Water use productivity $\left(\mathrm{kg} \mathrm{m}^{-3}\right)$ \\
\hline Reference & 4.60 & 99.098 & 21.543 & 14.82 & 156.47 & 13.77 \\
\hline Experimental & 3.70 & 85.640 & 23.146 & 8.56 & 132.83 & 17.43 \\
\hline
\end{tabular}

(1-2 days) and with lower amounts of water. From day 51, the SWC was maintained near the field capacity point.

Table 3 shows the most significant differences between the experimental and reference plots. The total volume of irrigation applied to the reference plot was $156.47 \mathrm{~mm}$, yielding a total commercial production of $21.543 \mathrm{~kg} \mathrm{ha}^{-1}$ of processed lettuce. This applied volume was $17.80 \%$ higher than the volume applied in the experimental plot; however, the SWC levels were maintained outside of the optimal range of moisture for nearly the entire crop cycle. This deficit of soil moisture caused the appearance of burns on the borders of the younger and interior leaves in a large amount of lettuce plants. This physiologic disorder is known as 'tipburn' and is produced by a deficient translocation of calcium in the plant (Sonneveld and Mook, 1983; Napier and Combrink, 2006). The appearance of tipburn caused a reduction in commercial production of $6.93 \%$ with respect to the production obtained in the experimental plot, mainly due to the high percentage of discard reached (14.82\%). This outcome reduced the productivity of water usage in the reference plot by $20.99 \%$ compared to the experimental plot, which reached $13.77 \mathrm{~kg} \mathrm{~m}^{-3}$.

\section{Conclusions}

Digital photography and its subsequent computer processing have established themselves as simple and robust techniques for estimating the fraction of vegetation cover. In this context, the methodology developed by Fernández-Pacheco et al. (2014) was calibrated and applied to a commercial lettuce crop (Lactuca sativa L. cv. 'Little Gem'). This allowed to determine with success the equations that relate PGC with the crop coefficient $K c$ to estimate the evapotranspiration during the whole crop season for later employment in water balance calculations and irrigation scheduling.

The management on the commercial farm was also compared. For this purpose, the soil moisture levels were monitored, and detected deficiencies were evaluated for adjustment with future crops by advising the irrigator. Concretely, a $6.93 \%$ increase in production and a $17.80 \%$ reduction in water consumption compared to the reference plot were achieved.

In summary, the use of digital photography and different computer processing techniques as support tools for water balance calculations and optimal irrigation management in lettuce crops obtained better economic crop yields associated with greater productivity and less water consumption for irrigation, as well as reduced appearance of physiological disorders such as tipburn.

\section{Acknowledgements}

This work was supported by the "Seneca Foundation" (Murcia Regional Authority, Spain) through project 08729/PI/08 and by the Spanish MINECO under grant TIN2012-38341-C04-03.

\section{References}

Adamsen, F., Coffelt, T., Nelson, J.M., Barnes, E.M., Rice, R.C., 2000. Method for using images from a color digital camera to estimate flower number. Crop Sci. 40, 704-709.

Allen, R.G., Pereira, L.S., Howell, T.A., Jensen, M.E., 2011. Evapotranspiration information reporting: I. Factors governing measurement accuracy. Agric. Water Manage. 98, 899-920.

Allen, R.G., Pereira, L.S., Raes, D., Smith, M., $1998 . \quad$ Crop Evapotranspiration-Guidelines for Computing Crop Water Requirements-FAO Irrigation and Drainage Paper 56. FAO, Rome

Folleto FAO Riego y Drenaje No 29. Food and Agriculture Organization of the United Nations, Rome. 


G Model
AGWAT-3975; No. of Pages 10

Bert Jr., J., Honma, S., 1975. Effect of soil moisture and irrigation method on tipburn and edgeburn severity in greenhouse lettuce. J. Am. Soc. Hortic. Sci. 100 (3), $278-282$

Blasco, J., Aleixos, N., Roger, J., Rabatel, G., Molto, E., 2002. AE-automation and emerging technologies: robotic weed control using machine vision. Biosyst. Eng. 83, 149-157.

Bowen, I.S., 1926. The ratio of heat losses by conduction and by evaporation from any water surface. Phys. Rev. Lett. 27 (6), 779-787.

Brown, P., Doley, D., Keenan, R., 2000. Estimating tree crown dimensions using digital analysis of vertical photographs. Agric. For. Meteorol. 100, 199-212.

Calera, A., Martínez, C., Meliá, J., 2001. A procedure for obtaining green plant cover: relation to NDVI in a case study for barley. Int. J. Remote Sens. 22, 3357-3362. Cayrol, P., Chehbouni, A., Kergoat, L., Dedieu, G., Mordelet, P., Nouvellon, Y., 2000 Grassland modeling and monitoring with SPOT-4 VEGETATION instrument dur-

Córcoles, J., Ortega, J., Hernández, D., Moreno, M., 2013. RETRACTED: Use of digital photography from unmanned aerial vehicles for estimation of leaf area index in Costa.j, Ortuno, M. Chaves, M.M. 2007. Deficiti

Costa, J.M., Ortunio, M.F., Chaves, M.M., 2007. Deficit irrigation as a strategy to save water: physiology and potential application to horticulture. J. Integr. Plant Biol.

Medeiros, G.A., Arruda, F.B., Sakai, E.l., Fujiwara, M., 2001. The influence of crop canopy on evapotranspiration and crop coefficient of beans (Phaseolus vulgaris

Drenbos, J., Pruitt, W.O., 1977. Las necesidades de agua de los cultivos (Vol. 24). FAO, Rome.

carabajal-Henarejos, D., Molina-Martínez, J.M., Fernández-Pacheco, D.G., GarcíaMateos, G., 2014. Methodology for obtaining prediction models of root depth of lettuce for its application in irrigation automation. Agric. Water Manage.,

wing, R.P., Horton, R., 1999. Quantitative color image analysis of agronomic images. Agron. J. 91, 148-153.

Fernández-Pacheco, D.G., Escarabajal-Henarejos, D., Ruiz-Canales, A., Conesa, J. Molina-Martínez, J.M., 2014. A digital image-processing-based method for determining the crop co
Biosyst. Eng. 117, 23-34.

Hanson, B.R., May, D.M.., 2006. Crop coefficients for drip-irrigated processing tomato. Agric. Water Manage. 81, 381-399.

Kenney, W., 1987. A method for estimating windbreak porosity using digitized photographic silhouettes. Agric. For. Meteorol, 39, 91-94.

Laliberte, A., Rango, A., Herrick, J., Fredrickson, E.L., Burkett, L., 2007. An object-based image analysis approach for determining fractional cover of senescent and green vegetation with digital plot photography. J. Arid. Environ. 69, 1-14.

López-Urrea, R., Martín de Santa Olalla, F., Montoro, A., López-Fuster, P., 2009. Single and dual crop coefficients and water requirements for onion (Allium cepa L.) under semiarid conditions. Agric. Water Manage. 96, 1031-1036.
Lorente, D., Aleixos, N., Gómez-Sanchis, J., Cubero, S., García-Navarrete, O.L. Blasco, J., 2012. Recent advances and applications of hyperspectral imaging for fruit and vegetable quality assessment. Food Bioprocess Technol. 5 ,

Meir, P., Grace, J., Miranda, A.C., 2000. Photographic method to measure the vertical distribution of leaf area density in forests. Agric. For. Meteorol. 102 105-111

Molina-Martínez, J.M., Jiménez, M., Ruiz-Canales, A., Fernández-Pacheco, D.G., 2011. RaGPS: a software application for determining extraterrestrial radiation in mobile devices with GPS. Comput. Electron. Agric. 78, 116-12

Napier, D.R., Combrink, N.J.J., 2006. Aspects of calcium nutrition to limit plant physiological disorders. Acta Hort. (ISHS) 702, 107-116.

Ortuño, M.F., Conejero, W., Moreno, F., Moriana, A., Intrigliolo, D.S., Biel, C., Mellisho, C.D., Pérez-Pastor, A., Domingo, R., Ruiz-Sánchez, M.C., Casadesus, J., Bonany, J. Torrecillas, A., 2010. Could trunk diameter sensors be used in woody crops for irrigation scheduling? A review of current knowledge and future perspectives.

Richardson, M.., Karcher, D., Purcell, L., 2001. Quantifying turfgrass cover using digital ín

entracción de macronutrientes en cultivo de lechuga iceberg. In: II Congreso Nacional de Fertirrigación. FIAPA-

Rincón, L., Sáez, J., 1997. Determinación de la evapotranspiración y de los coeficientes de cultivo de la lechuga Iceberg con riego por goteo. Acta Hort. (ISHS) $19,193-201$

Rincón, L., 2001. Necesidades hídricas, absorción de nutrientes y respuesta a la fertilización nitrogenada de la lechuga iceberg. Universidad de Murcia, Murcia Doctoral dissertation.

Rincón, L., 2005. La fertirrigación de la lechuga iceberg. Instituto Murciano de Investigación y Desarrollo Agrario y Alimentario, Murcia,

Salter, P.J., Goode, J.E., 1967. Crop Responses to Water at Different Stages of Growth. Commonwealth Agricultural Bureaux, England.

Saxton, K.E., Rawls, W.J., 2006. Soil water characteristic estimates by texture and organic matter for hydrologic solutions. Soil Sci. Soc. Am. J. 70, 1569-1578.

Sonneveld, C., Mook, E., 1983. Lettuce tipburn as related to the cation contents of different plant parts. Plant Soil. 75 (1), 29-40.

Sutton, B., Merit, N., 1993. Maintenance of lettuce root zone at field capacity gives best yields with drip irrigation. Sci. Hortic.-Amsterdam 56, 1-11.

Walthall, C., Dulaney, W., Anderson, M., Norman, J., Fang, H., Liang, S., 2004. A comparison of empirical and neural network approaches for estimating corn and soybean leaf area index from Landsat ETM+ imagery. Remote Sens. Environ. 92, 465-474.

Zhang, C., Kovacs, J.M., 2012. The application of small unmanned aerial systems for precision agriculture: a review. Precis. Agric. 13, 693-712.

Please cite this article in press as: Escarabajal-Henarejos, D., et al., Digital photography applied to irrigation management of Little Gem lettuce. Agric. Water Manage. (2014), http://dx.doi.org/10.1016/j.agwat.2014.08.009 


\subsection{Publicación 4}

\section{Methodology for obtaining prediction models of root depth of lettuce for its application in irrigation automation}

D. Escarabajal-Henarejos ${ }^{1}$, J.M. Molina-Martínez ${ }^{1}$, D.G. Fernández-Pacheco ${ }^{2}$, G. GarcíaMateos $^{3}$

${ }^{1}$ Grupo de Investigación en Ingeniería Agromótica y del Mar. Universidad Politécnica de Cartagena, $\mathrm{P}^{\mathrm{o}}$ Alfonso XIII 52, 30203 Cartagena, Murcia.

${ }^{2}$ Departamento de Expresión Gráfica. Universidad Politécnica de Cartagena, Campus de la Muralla del Mar, C/ Doctor Fleming s/n, 30202 Cartagena, Murcia.

${ }^{3}$ Departamento de Informática y Sistemas. Facultad de Informática. Universidad de Murcia, Campus Universitario de Espinardo, 30100 Murcia.

\section{RESUMEN}

La programación y automatización del riego suele llevarse a cabo aplicando procedimientos basados en la medición del contenido de agua en el suelo. En este sentido, el balance hídrico se ha consolidado como un buen indicador del crecimiento y desarrollo de los cultivos, y es muy utilizado en la actualidad en diversos sistemas de programación automática, básicamente en cultivos intensivos y en sistemas de riego por microirrigación. Esta metodología analiza las ganancias y pérdidas de agua en un volumen limitado de suelo, representadas principalmente por los riegos y los 
requerimientos hídricos del cultivo, para determinar la disponibilidad de agua para el cultivo y el estado hídrico del suelo. Un parámetro de gran importancia para la aplicación de este método es la profundidad del sistema radicular de la planta (z), pues permite acotar el volumen de suelo a considerar en dicho balance. En la mayoría de los casos, no se considera la evolución real de este parámetro durante el desarrollo del cultivo, pues se recurre a utilizar valores fijos tabulados o propuestos por la bibliografía, provocando en algunos periodos temporales de su desarrollo que el perfil de suelo considerado no se corresponda con el realmente explorado por el sistema radicular, con el consecuente desajuste en el balance hídrico. Se ha observado una buena relación entre la profundidad radicular y la fracción de cobertura vegetal, éste último directamente relacionado también con el desarrollo del cultivo y su demanda evapotranspirativa. En base a esta observación, se ha obtenido un modelo predictivo del espesor de la zona radicular de un cultivo de lechuga variedad 'Little Gem' a partir de la fracción de cobertura vegetal, cuya implantación en un sistema automatizado de gestión del riego permitirá la optimización del recurso agua, debido al ajuste del contenido hídrico a la zona realmente explorada por las raíces.

\section{INTRODUCCIÓN}

En la actualidad, el empleo del agua supone un factor fundamental para incrementar la productividad agrícola, siendo a la vez un recurso limitado. Dentro de la agricultura, la práctica del riego es uno de los procesos más complejos que debe realizar el agricultor debido a la multitud de factores implicados en el manejo del agua. La información técnica que permite optimizar el riego incluye el conocimiento preciso tanto del agua usada como del rendimiento del cultivo (Hsiao et al., 2009; Domínguez et al., 2011). Una alternativa a las clásicas funciones de producción empíricas es el uso de modelos de simulación de cultivos para el manejo del riego (Griffin et al., 1993; Stöckle et al., 2003). Esta modelación del crecimiento y desarrollo de los cultivos va a permitir predecir el comportamiento de éstos en una determinada zona ante cambios en las variables ambientales y edáficas.

Un modelo es una representación o abstracción, por lo general matemática, de un sistema real para predecir su comportamiento (Mize y Cox, 1968; Mackerron, 2007; Steduto et al., 2009). Su principal ventaja radica en su facilidad y rapidez para obtener predicciones de la realidad. La actual capacidad de procesamiento de los sistemas informáticos ha permitido que el conocimiento de la relación clima-suelo-planta pueda 
ser plasmado en modelos dinámicos (explicativos) que simulan el crecimiento y producción de los cultivos (Whisler et al., 1986; Boote et al., 2010). Esto ha llevado al desarrollo de nuevos modelos y metodologías que sirven como herramientas de apoyo para la gestión y optimización de los recursos hídricos en sistemas agrarios, quedando englobadas dentro del concepto de agricultura de precisión (Haboudane et al., 2004).

Estos modelos de programación del riego están basados físicamente en el balance de agua en la zona radicular del cultivo (Eilers et al., 2007, Nishat et al., 2007, Panigrahi y Panda, 2003; Shang y Mao, 2006). En este sentido, la profundidad del sistema radicular es un importante parámetro del desarrollo vegetativo del cultivo, cuya participación en el balance hídrico viene determinada por la necesidad de conocer el perfil de suelo explorado por el sistema radicular, en el cual es necesario mantener unas condiciones óptimas de humedad para el correcto desarrollo del cultivo (Rincón, 2005). La profundidad radicular está relacionada directamente con la tasa de profundización de las raíces, específica de cada cultivo, y con la textura del suelo, pues ésta determina la resistencia mecánica que ofrece el suelo al desarrollo radicular (Taylor y Brar, 1991). La profundidad radicular es una variable de entrada en los sistemas de programación del riego, que suele ser hallada mediante el empleo de valores fijos tabulados o propuestos por la literatura.

El conocimiento del valor de profundidad radicular en cada momento del desarrollo del cultivo permite optimizar las metodologías existentes de programación del riego basadas en el conocimiento del estado hídrico del suelo, ya que consiguen establecer un balance hídrico ajustado únicamente a la zona de absorción radicular. Este hecho demuestra la necesidad de estudiar nuevas metodologías que permitan obtener modelos de evolución de la profundidad radicular en cada momento del desarrollo del cultivo (Sammis et al., 2012; Ma et al., 2013).

Otro importante parámetro indicador del desarrollo de los cultivos es el porcentaje de cobertura vegetal $(P G C)$, que está directamente relacionado con la evapotranspiración del cultivo a través del coeficiente de cultivo Kc (Allen et al., 1998, 2007), cuya relación ha sido estudiada en diversos sistemas de riego, obteniéndose resultados exitosos en tomate (Hanson y May, 2005), fríjol (De Medeiros et al., 2001) y cebolla (López-Urrea et al., 2009). El porcentaje de cobertura vegetal puede ser estimada con gran precisión mediante el empleo de técnicas de procesamiento digital de fotografías aéreas de la cubierta vegetal, obteniéndose resultados satisfactorios (Congling et al., 2005). Además, 
el porcentaje de cobertura del suelo también ha sido correlacionado con la altura de la planta, proporcionando resultados satisfactorios en arbustos ornamentales (Grant et al., 2012), trigo de invierno (Xu et al., 2010) y plantas de humedales construidos (Xiao et al., 2011), entre otros, y obteniéndose modelos matemáticos de precisión bastante precisos para la determinación del coeficiente de cultivo $K c$ en lechuga (Fernández-Pacheco et al., 2014).

En este artículo se ha desarrollado y validado una metodología para obtener modelos de predicción del espesor de la zona radicular de un cultivo de lechuga (Lactuca sativa L. cv. 'Little Gem') a partir del $P G C$ del cultivo obtenido mediante tratamiento de imágenes digitales del cultivo. En primer lugar, se calcular el $P G C$ a partir del procesamiento informático de fotografías digitales de la cubierta vegetal y posteriormente se correlaciona con la profundidad radicular. La metodología propuesta ha sido evaluada considerando la precisión de la estimación obtenida por las ecuaciones matemáticas proporcionadas por el método.

\section{MATERIALES Y MÉTODOS}

\subsection{Parcela experimental}

Para el desarrollo del presente trabajo se llevó a cabo un seguimiento de cuatro plantaciones comerciales de lechuga variedad Little Gem, de vigor bajo (Lactuca sativa L. cv. 'Little Gem'), durante los años 2011 y 2012, agrupadas en dos temporadas: dos plantaciones en primavera (de abril a junio) en una finca de 20,4 ha localizada en la pedanía de Pozohondo (latitud 38³9'20' 'N, longitud 147'14'’W y altitud $869 \mathrm{~m}$ ) en la provincia de Albacete, España; y dos plantaciones en otoño (de octubre a diciembre) en

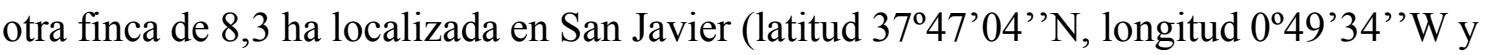
altitud $15 \mathrm{~m}$ ) en la provincia de Murcia, España. Las plantas de lechuga se obtuvieron en semillero aparte y se trasplantaron a densidad de plantación de 16,5 plantas $\cdot \mathrm{m}^{-2}$.

En ambas fincas, el suelo de la parcela está clasificado como "Calcic Petrocalcids" y tiene una profundidad media alrededor de $40 \mathrm{~cm}$, limitado por el desarrollo del horizonte petrocálcico más o menos fragmentado. La textura predominante en ambas es franco arcillosa y pedregosidad media. Ambas parcelas están equipadas con sistema automatizado de riego localizado. Con el objetivo de obtener la misma pluviometría se colocó una tubería emisora por cada línea pareada de plantas con goteros cada $30 \mathrm{~cm}$, de 
$21 \cdot \mathrm{h}^{-1}$ de descarga unitaria en las líneas pareadas simples y $11 \cdot \mathrm{h}^{-1}$ de descarga unitaria en las líneas pareadas dobles.

En la parcela de Pozohondo, el clima se clasifica como Mediterráneo continental (Papadakis, 1966). Durante los ciclos de cultivo en esta zona, la temperatura media fue de $15,9{ }^{\circ} \mathrm{C}$ y $13,6^{\circ} \mathrm{C}$ respectivamente para los años 2011 y 2012. La temperatura media máxima fue de $22,8{ }^{\circ} \mathrm{C}$ y $19{ }^{\circ} \mathrm{C}$ y la temperatura media mínima fue de $8,9{ }^{\circ} \mathrm{C}$ y $7,3{ }^{\circ} \mathrm{C}$, respectivamente. La precipitación total registrada durante la temporada de primavera fue de $48,9 \mathrm{~mm}$ en 2011 y $111,1 \mathrm{~mm}$ en 2012 .

En la parcela de San Javier, el clima de la zona se clasifica como Mediterráneo subtropical (Papadakis, 1966). Durante los ciclos de cultivo en esta zona, la temperatura media fue de $16,1^{\circ} \mathrm{C}$ y $16,7^{\circ} \mathrm{C}$ respectivamente para los años 2011 y 2012 . La temperatura media máxima fue de $20,9{ }^{\circ} \mathrm{C}$ y $22,2{ }^{\circ} \mathrm{C}$ respectivamente, y la temperatura media mínima fue de $11,5{ }^{\circ} \mathrm{C}$ en ambas temporadas. La precipitación total registrada durante la temporada de otoño fue de $75 \mathrm{~mm}$ en 2011 y $58 \mathrm{~mm}$ en 2012 .

\subsection{Recogida de datos}

Durante los ciclos de cultivo de cada plantación, en cada finca se delimitaron cuatro subparcelas de muestreo de $1,8 \mathrm{~m}^{2}(1,8 \mathrm{~m} \mathrm{x} 1,0 \mathrm{~m})$, representativas del cultivo y distribuidas aleatoriamente evitando la zona externa de la plantación para eliminar el efecto borde. A partir del primer día de trasplante, y a intervalos de 2-3 días, se llevó a cabo un seguimiento del cultivo en el que se midió la profundidad radicular media de las plantas de lechuga y se determinó el $P G C$ en cada subparcela de muestreo.

Dado que el sistema radicular de las plantas de lechuga es de tipo pivotante, en cada parcela de muestreo se realizaron varias catas en el terreno a fin de identificar la raíz primaria y se midió su longitud, considerándose ésta como valor de profundidad radicular. Para determinar el $P G C$ en cada subparcela de muestreo, se realizaron fotografías verticales del dosel vegetal mediante el empleo de una cámara digital compacta (Coolpix S3300, Nikon, Japón) equipada con un dispositivo de carga acoplado (CCD) (resolución, 16,0 megapíxeles; distancia focal, 27,6 mm) que estaba montada sobre un trípode a una altura fija de 1,40 m sobre el nivel del suelo. Para hacer coincidir $P G C$ con la fracción de área sombreada por la planta, las fotografías fueron tomadas al mediodía solar. Es recomendable tomar varias fotografías de cada subparcela y posteriormente seleccionar 
la mejor toma (es decir, aquellas fotografías que no muestren defectos de luminosidad o concavidad y estén correctamente enmarcadas).

Tras tomar las fotografías de las cuatro subparcelas de muestreo y seleccionar las mejores tomas, las imágenes fueron pre-procesadas digitalmente de tal manera que sólo se dejó el interior del marco. Para este fin se puede utilizar cualquier software de edición de fotografía disponible en el mercado. Debido a que el método aquí propuesto calcula la cobertura del suelo en forma de porcentaje (más que el número de píxeles), la resolución final de la imagen no afectará a los resultados; el método es, por lo tanto escala-invariante. En otras palabras, ya que el porcentaje divide el número de píxeles de vegetación por el número total de píxeles de la imagen, esta proporción seguirá siendo la misma aunque la imagen se escale.

Las imágenes pre-procesadas fueron posteriormente procesadas usando el software ENVI $^{\circledR}$ (Environment for Visualizing Images) (Research System Inc., Boulder, CO, EE.UU.), que proporciona un entorno fácil de utilizar para mostrar y analizar imágenes de cualquier tamaño y tipo de datos.

La primera fase fue la segmentación de la imagen para discriminar entre suelo (beige) y vegetación (verde). El software permite definir esas dos clases y seleccionar las regiones de interés (ROIs) en la imagen que se referían a la misma clase (Fig. 3.1). Una vez se definieron estas ROIs, la imagen fue segmentada utilizando una clasificación supervisada de máxima similitud de la imagen en función de las ROIs definidas. Tras la segmentación, se obtuvieron el número de píxeles de la imagen correspondientes a vegetación (V), a suelo (S) y totales $(\mathrm{T})$, siendo utilizados posteriormente para calcular el porcentaje de cobertura del suelo como la relación V/T. Una vez obtenido el porcentaje de cobertura del suelo para cada subparcela, se calculó el valor promedio de las 4 subparcelas para cada día de muestreo. Una descripción más detallada del método del procesamiento digital de imágenes lo proporciona Fernández-Pacheco et al. (2014).

\subsection{Obtención de funciones de aproximación y comparación estadística}

Durante el año 2011 se llevó a cabo el seguimiento de dos campañas de cultivo, una en primavera y otra en otoño. El seguimiento de dichas campañas permitió capturar la evolución de $P G C$ y la profundidad radicular (z), tal y como se muestra en las Figs. 3.2a y $3.2 b$. Se puede comprobar que ambos parámetros describen una curva de crecimiento muy similar, lo que evidencia una buena correlación entre ambas componentes del 
crecimiento del cultivo. Esto permite definir una función de estimación de la profundidad radicular a partir de los datos de fracción de cobertura. Para ello, se usaron los pares de datos obtenidos durante las dos campañas realizadas en 2011 y se analizaron varias funciones de aproximación, incluyendo el modelo logarítmico, exponencial, logístico y Gompertz.

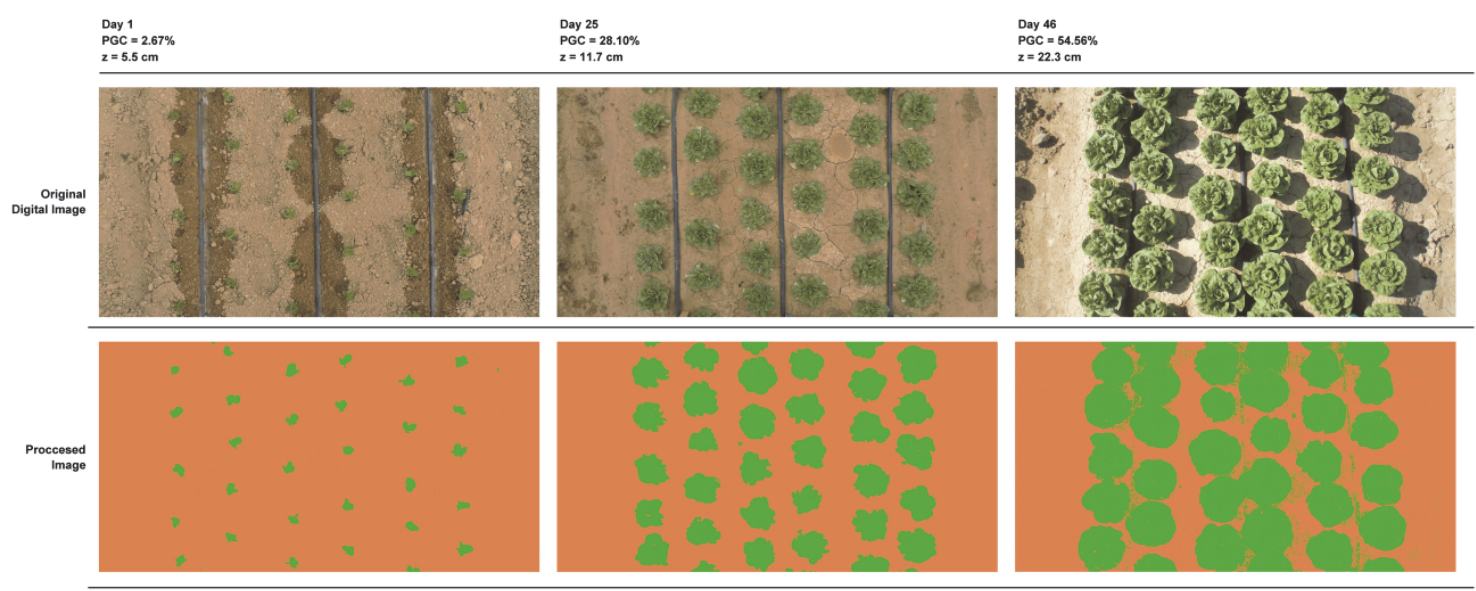

Fig. 3.1. Muestra de los resultados obtenidos usando el software de procesamiento de imágenes.

Estos modelos fueron ajustados utilizando la herramienta Solver de Excel (Microsoft Corporation, EE.UU.) que permite resolver problemas de optimización lineal y no lineal, pudiéndose incluir restricciones enteras sobre las variables de decisión. Los valores medidos y estimados de profundidad radicular fueron comparados entre sí mediante regresión lineal simple y el empleo de los estadígrafos dados por Willmott (1982). La raíz del error cuadrático medio (RMSE) se calculó como:

$$
\mathrm{RMSE}=\sqrt{\frac{1}{n} \Sigma\left(P_{i}-O_{i}\right)^{2}}
$$

donde $n$ es el número de pares de datos, y $P_{i}$ y $O_{i}$ son los valores de profundidad radicular estimados por el modelo y observados, respectivamente. Además, se calculó el índice de similitud (IA) para describir las diferentes entre los valores comparados, tal como:

$$
\mathrm{IA}=1-\frac{\Sigma\left(P_{i}-O_{i}\right)^{2}}{\Sigma\left(\left|P_{i}-O_{m e d}\right|+\left|O_{i}-O_{m e d}\right|\right)^{2}}
$$

donde $O_{\text {med }}$ corresponde al valor medio de la variable $O$. Se seleccionó como solución óptima aquella que proporcionó el mínimo RMSE y máximo IA. 

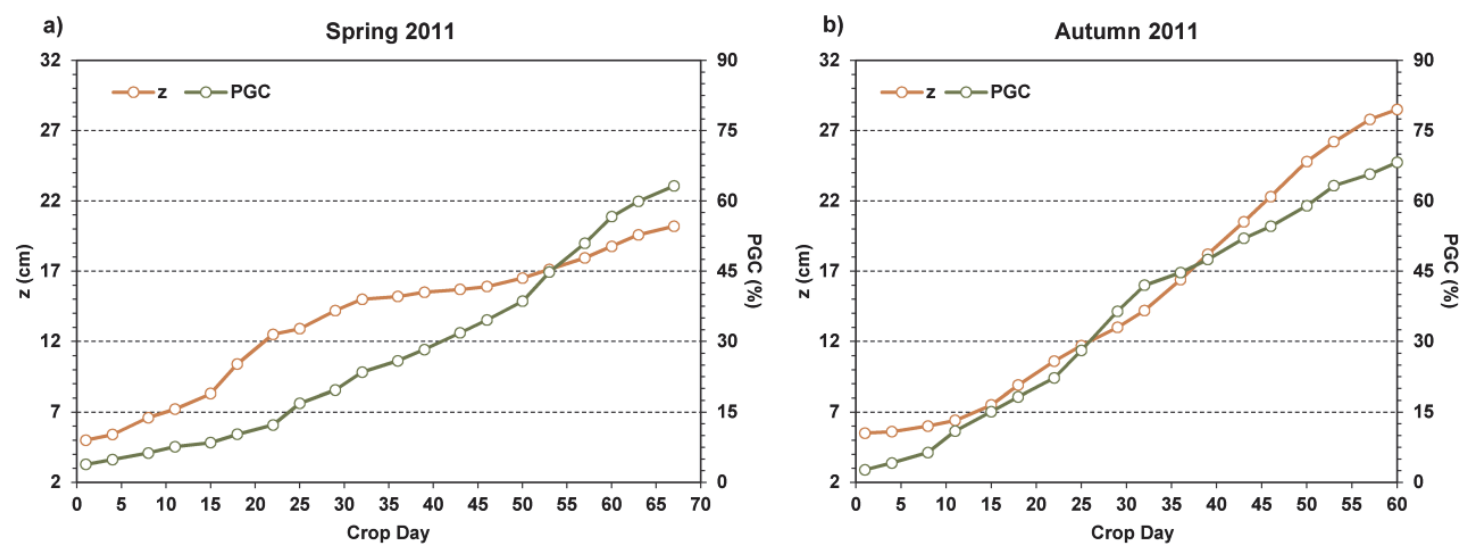

Fig. 3.2. Evolución de la profundidad radicular $(z)$ y porcentaje de cobertura del suelo $(P G C)$ durante las plantaciones de 2011: a) primavera y b) otoño.

\section{RESULTADOS Y DISCUSIÓN}

La Fig. 3.2. muestra la evolución del parámetro $P G C$ y profundidad radicular durante los cultivos de primavera y otoño de 2011. En ambos casos, $P G C$ aumentó casi linealmente hasta valores superiores a $60 \%$ en recolección ( $63,2 \%$ en primavera y $68,2 \%$ en otoño). Además, la profundidad radicular describió un crecimiento similar, no excediendo la profundidad media del suelo de $40 \mathrm{~cm}$ y alcanzando $20,2 \mathrm{~cm}$ en primavera y $28,5 \mathrm{~cm}$ en otoño, valores esperados en condiciones de riego por goteo y suelos franco-arcillosos (Rincón, 2005). También se investigó la relación entre el parámetro $P G C$ y la profundidad radicular. Para este propósito, se analizaron diversas funciones de aproximación. Durante el cultivo de primavera de 2011, los mejores resultados fueron obtenidos usando un modelo de aproximación logarítmico (Ec. 3), donde $y=z(\mathrm{~cm}), x=P G C(\%), a=5,370$ y $b=-2,602$.

$$
y=a \cdot \ln (x)+b
$$

Para evaluar el comportamiento de la ecuación, se compararon los valores de profundidad radicular medidos y estimados empleando la Ec. 3 (Fig. 3.3a). También se realizó un análisis de regresión lineal, obteniéndose una pendiente de la recta de regresión lineal muy similar a $1(0,981)$ y un coeficiente de correlación $\mathrm{R}^{2}$ de 0,981 (Fig. 3.4a). La raíz cuadrada del error cuadrático medio (RMSE) fue de $0,649 \mathrm{~cm}$, y el índice de similitud fue 0,995 , lo que demuestra que la diferencia entre los valores reales y los valores estimados por el modelo fue mínima.

La ecuación obtenida en primavera (Ec. 3) fue empleada posteriormente en el cultivo de otoño para estimar la profundidad radicular. En este caso, los valores reales de profundidad radicular fueron sobrestimados por el modelo hasta que $P G C$ alcanzó el valor 
de 47,5\% (día 39), valor a partir del cual la función subestimó los valores reales de profundidad radicular (Fig. 3.3b). El análisis de regresión lineal realizado entre los valores de profundidad radicular reales y estimados usando la Ec. 3 proporcionó un coeficiente de correlación de 0,746 y una pendiente de la recta de regresión lineal de 0,571 (Fig. 3.4b). En este caso, la bondad del ajuste fue inferior, obteniéndose un RMSE de 4,316 cm y un índice de similitud de 0,885 .
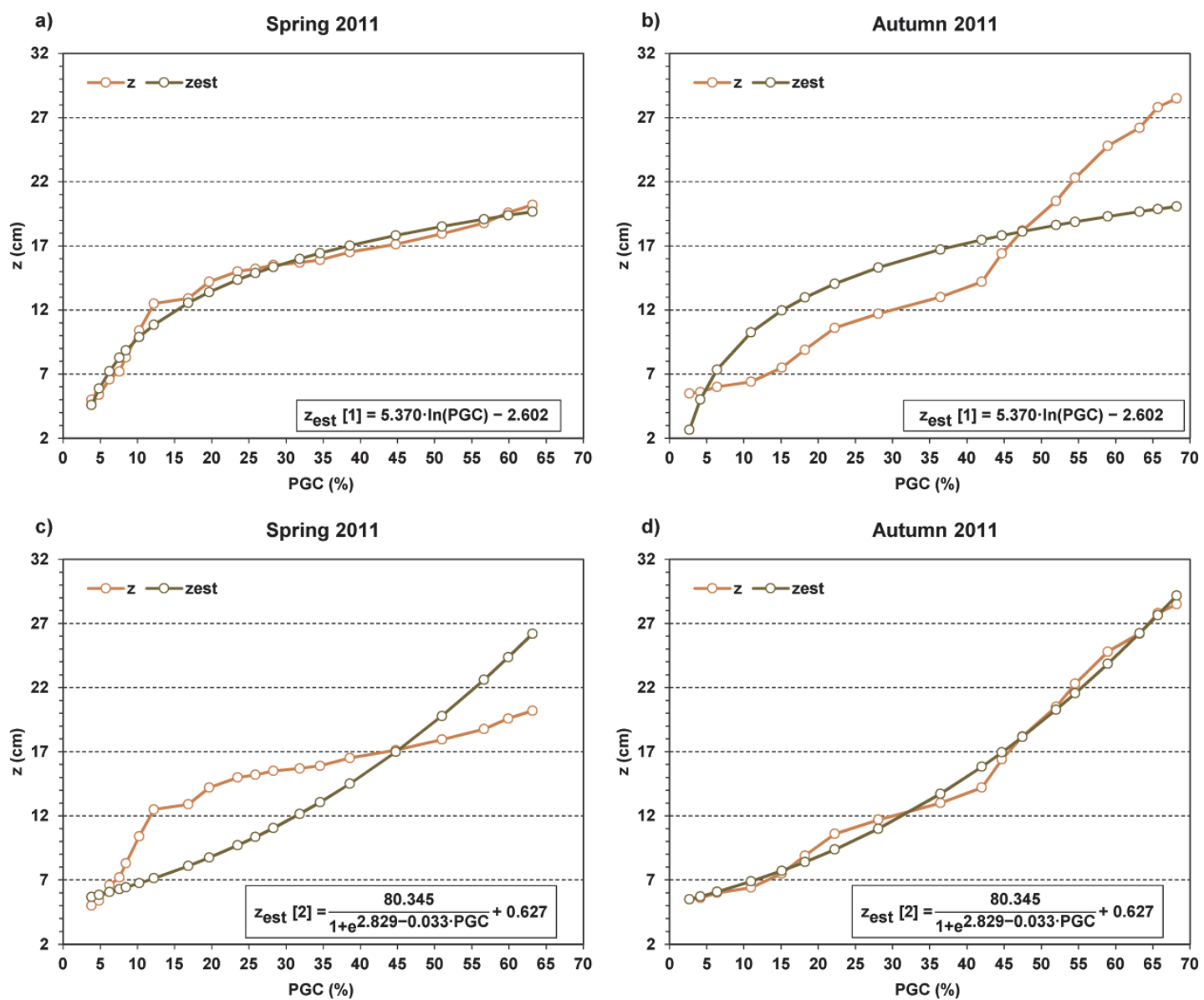

Fig. 3.3. Valores estimados $\left(z_{e s t}\right)$ y reales $(z)$ de profundidad radicular durante los cultivos de 2011 empleando los modelos logarítmico $\left(z_{\text {est }}[1]\right)$ y logístico $\left(z_{e s t}[2]\right)$.

Considerando estos resultados, se ensayó una función de aproximación diferente para correlacionar los valores de profundidad radicular y $P G C$ para el cultivo de otoño. En este caso, los mejores resultados correspondieron al modelo de crecimiento logístico (Ec. 4), donde $y=z(\mathrm{~cm}), x=P G C(\%), a=80,345, b=2,829, c=-0,033$ y $d=0,627$.

$$
y=\frac{a}{1+\mathrm{e}^{b+c \cdot x}}+d
$$

Para evaluar el comportamiento de la ecuación, se compararon los valores de profundidad radicular medidos y estimados empleando la Ec. 4 (Fig. 3.4d). También se 
realizó un análisis de regresión lineal, obteniéndose una pendiente de la recta de regresión lineal muy similar a $1(0,994)$ y un coeficiente de correlación $\mathrm{R}^{2}$ de 0,993 . En este caso, la raíz cuadrada del error cuadrático medio (RMSE) fue de 0,666 cm, y el índice de similitud fue 0,998 , lo que demuestra que la diferencia entre los valores reales y los valores estimados por el modelo fue mínima.
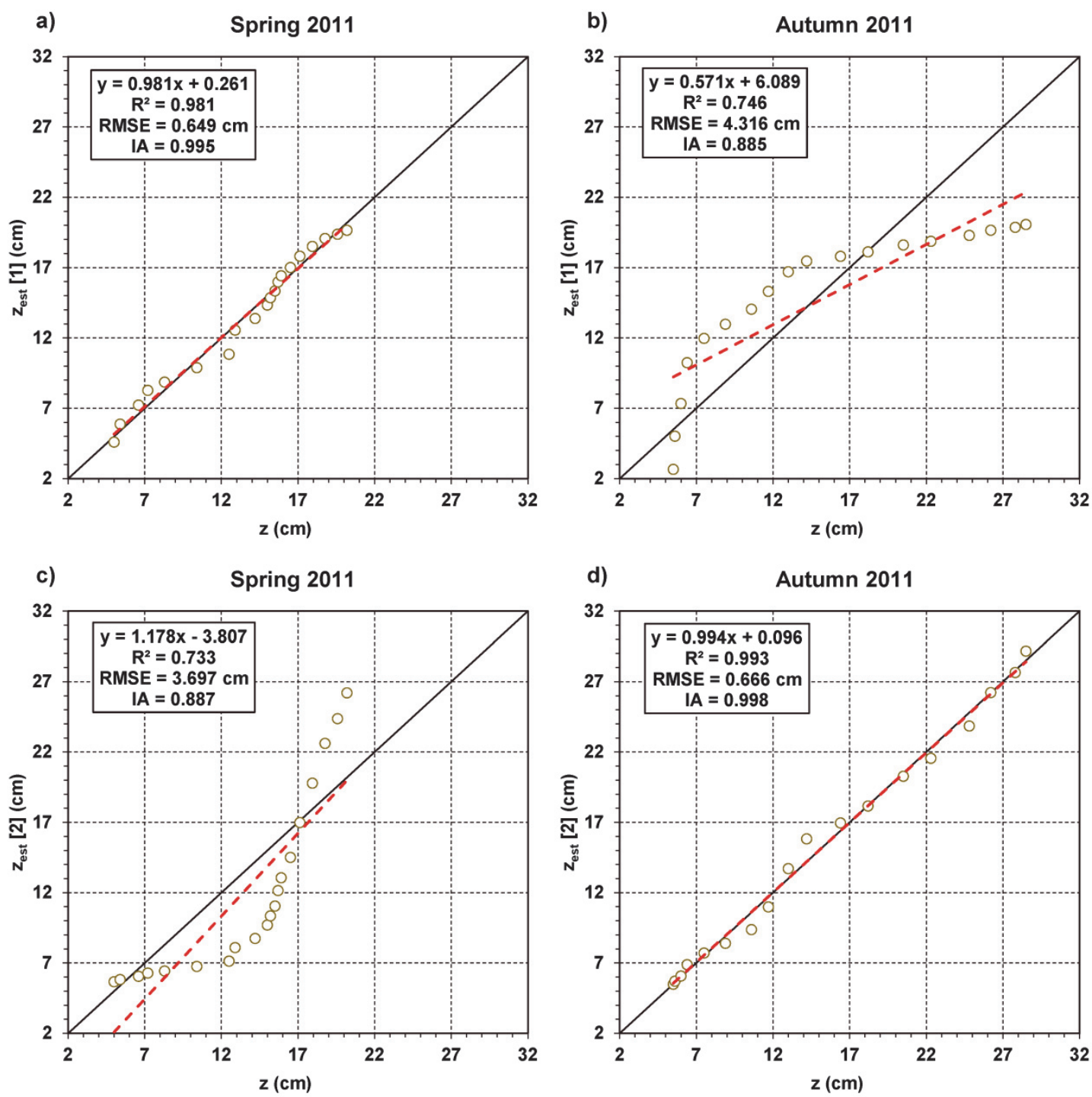

Fig. 3.4. Análisis de regresión lineal entre los valores reales de profundidad radicular $(z)$ y los valores estimados empleando el modelo logarítmico $\left(z_{e s t}[1]\right)$ y el modelo logístico $\left(z_{e s t}[2]\right)$ durante los cultivos de 2011.

La ecuación obtenida para otoño de 2011 (Ec. 4) también fue evaluada para estimar los valores de profundidad radicular en el cultivo de primavera. En este caso, los valores reales de profundidad radicular fueron subestimados por el modelo hasta que $P G C$ alcanzó el valor de 44,8\% (día 53), valor a partir del cual la ecuación sobreestimó los valores reales de profundidad radicular (Fig. 3.3c). 
El análisis de regresión lineal realizado entre los valores de profundidad radicular reales y estimados usando la Ec. 4 proporcionó un coeficiente de correlación de 0,733 y una pendiente de la recta de regresión lineal de 1,178 (Fig. 3.4c). La raíz cuadrada del error cuadrático medio (RMSE) fue de $3,697 \mathrm{~cm}$, y el índice de similitud fue 0,887, lo que demuestra que la profundidad radicular durante el cultivo de primavera fue mejor estimada por la Ec. 3 que por la Ec. 4 .

Según lo expuesto, se puede concluir que la metodología propuesta presenta una fuerte componente de estacionalidad, que condiciona el tipo de función de aproximación. Mientras en la plantación llevada a cabo en primavera, el modelo logarítmico es el que comporta mejor ajuste entre las variables $P G C$ y profundidad radicular, no ocurre lo mismo en la plantación de otoño, en el que el modelo logístico es el que mejor relaciona ambas variables. No obstante, la metodología propuesta está basada en la dependencia existente entre la fracción de cobertura vegetal y la profundidad radicular observada en ambas estaciones anuales ensayadas, y obteniendo coeficientes de determinación muy próximos a la unidad y RMSE siempre inferiores a $0,900 \mathrm{~cm}$.

Para demostrar la validez de la metodología desarrollada, las ecuaciones obtenidas durante las plantaciones de 2011 fueron aplicadas en condiciones similares durante las plantaciones de 2012 (Fig. 3.5). El análisis de regresión lineal llevado a cabo en ambos cultivos reportó una pendiente de recta de regresión lineal muy similar a $1(1,002$ y 0,935 para primavera y otoño, respectivamente) y un coeficiente de correlación $\mathrm{R}^{2}$ de 0,987 y 0,999, respectivamente (Fig. 3.5). Los valores obtenidos de RMSE fueron 0,536 cm y 0,830 , respectivamente, valores muy similares a los obtenidos en las plantaciones de 2011.

\section{CONCLUSIONES}

El artículo presenta una nueva metodología para estimar la profundidad radicular de cultivos de lechuga basada en fotografías digitales de la cubierta vegetal durante sus dos ciclos de cultivo en el Sureste de España. Para este cálculo, primero se estima el parámetro $P G C$ mediante procesamiento de fotografías digitales empleando $\mathrm{ENVI}^{\circledR}$, y a continuación, se correlaciona con la profundidad radicular. Durante el cultivo de primavera, esta metodología permitió obtener una ecuación logarítmica para modelar la relación entre ambos parámetros; obteniéndose un coeficiente de correlación de 0,987 en 2012. Para el cultivo de otoño, una ecuación logística arrojó las mejores estimaciones; 
obteniéndose un coeficiente de correlación de 0,999 en 2012, lo que demuestra la validez de esta metodología.
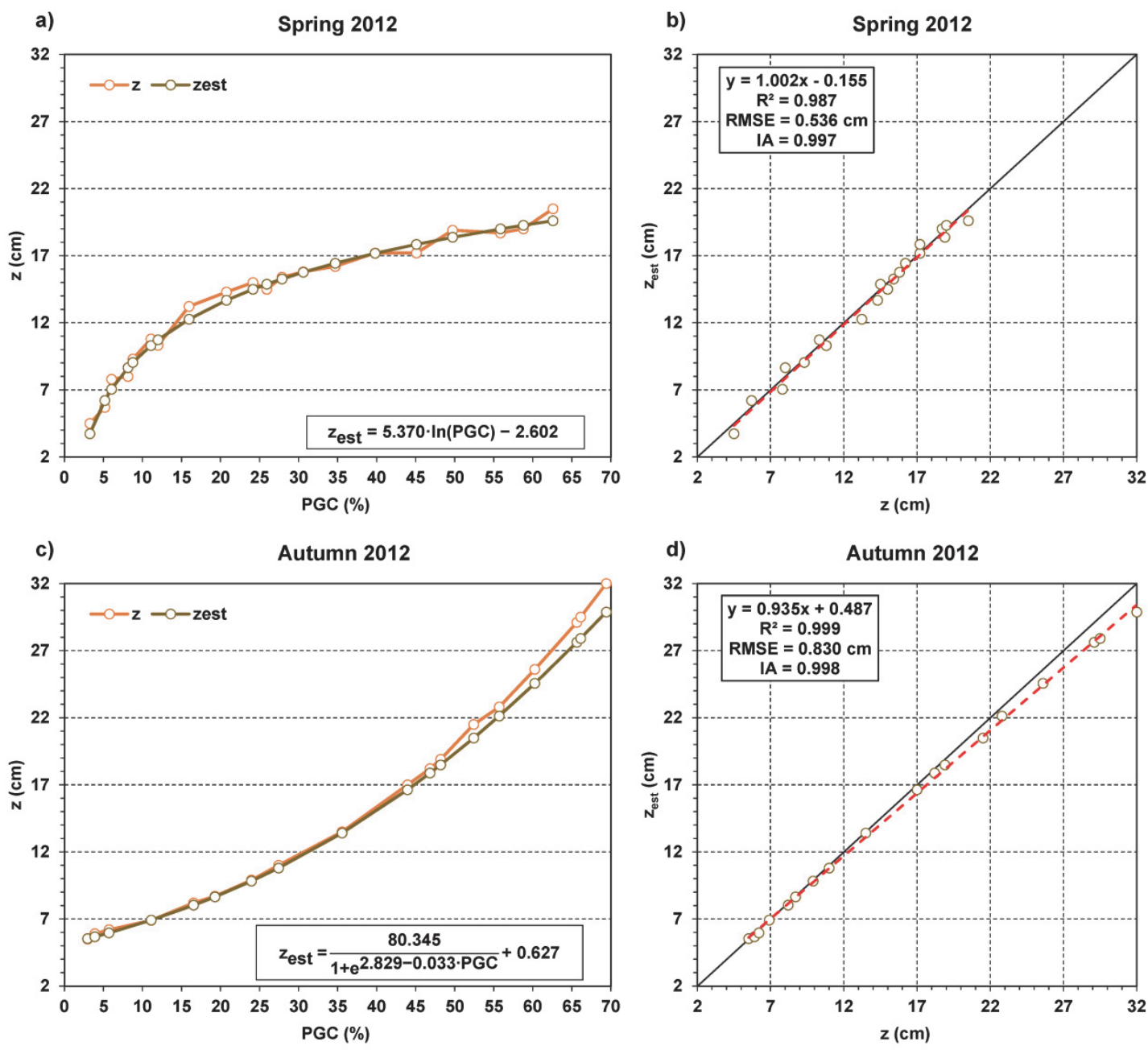

Fig. 3.5. Relación entre el porcentaje de cobertura vegetal $(P G C)$ y valores reales y estimados de profundidad radicular durante los cultivos de 2012: a) primavera y c) otoño; análisis de regresión lineal entre los valores reales $(z)$ y estimados $\left(z_{e s t}\right)$ de profundidad radicular obtenidos con b) un modelo logarítmico para cultivo de primavera y d) un modelo logístico para cultivo de otoño.

Los valores de profundidad radicular reales y estimados que fueron propuestos por las ecuaciones obtenidas fueron comparados para las cuatro temporadas (dos en $2011 \mathrm{y}$ dos en 2012). Los resultados demostraron una estrecha relación entre el parámetro $P G C$ y la profundidad radicular. Por lo tanto, la metodología puesta se basa en dicha relación, considerando la fuerte componente estacional que condiciona el tipo de ecuación que proporciona las mejores estimaciones dependiendo del ciclo de cultivo.

La metodología propuesta permite desarrollar algoritmos más precisos para riego inteligente. Se trata de una herramienta analítica de aplicación en sistemas automáticos 
de riego que proporciona una optimización del beneficio económico del cultivo de lechuga atendiendo al agua consumida, pues el conocimiento de la profundidad radicular en cada momento del desarrollo del cultivo, permite ajustar las prácticas de gestión del riego para mantener condiciones óptimas de humedad únicamente la zona radicular del cultivo. 



\title{
Methodology for obtaining prediction models of the root depth of lettuce for its application in irrigation automation
}

\author{
D. Escarabajal-Henarejos ${ }^{a, *}$, J.M. Molina-Martínez ${ }^{\mathrm{a}}$, \\ D.G. Fernández-Pacheco ${ }^{\mathrm{b}}$, G. García-Mateos $^{\mathrm{c}}$
}

${ }^{a}$ Research Group in Agromotic Engineering and the Sea, Technical University of Cartagena, Cartagena 30203, Spain ${ }^{\mathrm{b}}$ Graphical Expression Department, Technical University of Cartagena, Cartagena 30202, Spain ' Computer Science and Systems Department, University of Murcia, Murcia 30100, Spain

\section{A R T I C L E I N F O}

\section{Article history:}

Available online $\mathrm{xxx}$

\section{Keywords:}

Water balance

Percentage of ground cover

Digital image processing

\begin{abstract}
A B S T R A C T
Irrigation scheduling and automation are usually conducted using models that are based on the measurement of the soil water content. In this sense, water balance has established itself as a good indicator of the growth and development of crops and is currently used in several automatic programming systems, primarily in intensive farming and microirrigation systems. This method analyses the gains and losses of water in a limited volume of soil to determine the water availability for crops and the soil water status. A parameter of great importance for the application of this method is the root depth, which limits the soil volume to be considered in the water balance. In most cases, the actual evolution of this parameter during crop development is not considered, using instead fixed tabulated values or values that have been proposed in the literature. However, during some periods of crop development, the soil profile that is considered for the water balance does not correspond to the profile that is actually explored by the root system, resulting in a mismatch in the water balance. A good relationship between the root depth and the percentage of ground cover in lettuce has been observed, the latter of which is associated with crop development and the evapotranspirative demand. Therefore, this paper presents a methodology for obtaining prediction models of the root depth of the 'Little Gem' lettuce crop from the percentage of ground cover. The implementation of this prediction model in an automated irrigation management system will permit the optimisation of water resources due to the adjustment of the water content to the actual volume that is explored by the roots.

\section{Introduction}

Water consumption is currently one of the major factors increasing agricultural productivity, albeit being a limited resource. In this context, irrigation is one of the most complex processes that are performed by the farmer due to the multitude of factors that are involved in water management. The technical information that permits the optimisation of irrigation includes a precise knowledge of both the water usage and crop performance (Hsiao et al., 2009 Domínguez et al., 2011). An alternative to classical empirical production functions is the use of crop simulation models for irrigation management (Griffin et al., 1993; Stöckle et al., 2003).

* Corresponding author at: Dpto. Ingeniería de los Alimentos y del Equipamiento Agrícola, Universidad Politécnica de Cartagena, P(Alfonso XIII, 52, 30202 Cartagena, Spain. Tel.: + 349683259 29; fax: +34968 327031 .

E-mail address: david.escarabajal@gmail.com (D. Escarabajal-Henarejos).
A model is a representation or abstraction, generally a mathematical one, of an actual system with the aim of predicting its behaviour (Mize and Cox, 1968; Mackerron, 2007; Steduto et al., 2009). The main advantage of models lies in their easiness and efficiency predicting of reality. The current processing power of computer systems has permitted the knowledge of the climate-soil-crop relationship to be expressed in dynamic models (explanatory models) that simulate growth and crop production (Whisler et al., 1986; Boote et al., 2010). This knowledge has led to the development of new models and methodologies that serve as support tools for the management and optimisation of water resources in agricultural systems, which are encompassed within the concept of precision agriculture (Haboudane et al., 2004).

These irrigation scheduling models are physically based on the water balance at the crop root zone (Eilers et al., 2007; Nishat et al., 2007; Panigrahi and Panda, 2003; Shang and Mao, 2006). In this sense, the depth of the root system is an important parameter of vegetative crop development, whose involvement in water 


G Model
AGWAT-4031; No.of Pages 7
2
D. Escarabajal-Henarejos et al. / Agricultural Water Management $x x x$ (2014) $x x x-x x x$

balance is determined by the need to know the soil profile that is explored by the root system, as it is necessary to maintain the optimum moisture conditions for the proper development of the crop (Rincón, 2005). The root depth is directly related to the rate of root penetration, which is specific to each crop, and with soil texture, which determines the mechanical resistance of the soil to root growth (Taylor and Brar, 1991). Therefore, the root depth is an input variable in irrigation scheduling systems and is typically estimated using fixed tabulated values or values that have been suggested in the literature.

Knowing the precise value of the root depth at each instant of crop development enables the optimisation of existing methodologies for irrigation scheduling based on knowledge of the soil water status, as this knowledge permits the establishment of a water balance that is adjusted only to the root absorption area, demonstrating the need for new methodologies to obtain models of the evolution of the rooting depth at each stage of development (Sammis et al., 2012; Ma et al., 2013).

Another transcendent parameter that is an indicator of the crop status is the fraction of vegetation cover or percentage of ground cover (PGC), which is directly related to crop evapotranspiration through the crop coefficient Kc (Allen et al., 1998, 2007), whose relationship has been studied in various irrigation systems, having obtained successful results in tomato (Hanson and May, 2006), bean (De Medeiros et al., 2001) and onion (López-Urrea et al., 2009). PGC can be estimated with high accuracy by applying digital imageprocessing techniques of aerial photographs of the vegetation cover (Congling et al., 2005). Furthermore, the percentage of ground cover has also been correlated with plant height, generating successful results in ornamental shrubs (Grant et al., 2012), winter wheat (Xu et al., 2010) and constructed wetland plants (Xiao et al., 2011), among others, and producing fairly accurate mathematical models for the precise estimation of the lettuce crop coefficient Kc (Fernández-Pacheco et al., 2014).

This paper describes the design and validation of a new methodology for creating prediction models of the depth of the root zone of lettuce crops (Lactuca sativa L. cv 'Little Gem') from the PGC that was obtained by digital image processing. This PGC is the first to be calculated from the computer processing of digital photographs of the vegetation cover and then correlated with the root depth. The proposed methodology has been evaluated considering the accuracy of the estimation that was obtained by the mathematical equations that were provided by the method.

\section{Materials and methods}

\subsection{Experimental plots}

For the development of this research, four commercial lettuce crops of variety Little Gem, with low vigour (Lactuca sativa L. cv 'Little Gem'), were monitored in 2011 and 2012 and grouped into two seasons: two crops in the spring (from April to June) in a plot of an approximate area of 20.4 ha located in Pozohondo (latitude $38^{\circ} 39^{\prime} 20^{\prime \prime} \mathrm{N}$, longitude $1^{\circ} 47^{\prime} 14^{\prime \prime} \mathrm{W}$ and altitude $869 \mathrm{~m}$ ) in the province of Albacete, Spain; and two crops in the autumn (from October to December) in another plot of 8.3 ha located in San Javier (latitude $37^{\circ} 47^{\prime} 04^{\prime \prime} \mathrm{N}$, longitude $0^{\circ} 49^{\prime} 34^{\prime \prime} \mathrm{W}$ and altitude $15 \mathrm{~m}$ ) in the province of Murcia, Spain. The lettuce seedlings were obtained in a seedbed and transplanted at a density of 16.5 plants $\mathrm{m}^{-2}$.

In both of the plots, the soil was classified as "Calcic Petrocalcids" (Baillie, 2001), and the average depth was approximately $40 \mathrm{~cm}$, limited by the existence of a petrocalcic horizon that was more or less fragmented. The predominant texture was clay-loam with an average stoniness in both cases. The two plots were equipped with automated drip-irrigation systems. With the purpose of obtaining the same pluviometry, an emitting pipe was placed for each paired line of plants with drippers each $30 \mathrm{~cm}$, with a flow rate of $2 \mathrm{~L} \mathrm{~h}^{-1}$ unitary discharge in single paired line and $1 \mathrm{~L} \mathrm{~h}^{-1}$ unitary discharge in double-paired lines.

In the plot of Pozohondo, the climate of the zone was continental Mediterranean (Papadakis, 1966). During the crop seasons, the average temperatures in this plot were $15.9^{\circ} \mathrm{C}$ and $13.6^{\circ} \mathrm{C}$ in 2011 and 2012, respectively. The average maximum temperatures were $22.8^{\circ} \mathrm{C}$ and $19^{\circ} \mathrm{C}$, and the average minimum temperatures were $8.9^{\circ} \mathrm{C}$ and $7.3^{\circ} \mathrm{C}$, respectively. The total rainfall that was recorded during the spring season was $48.9 \mathrm{~mm}$ in 2011 and $111.1 \mathrm{~mm}$ in 2012.

In the plot of San Javier, the climate of the zone was subtropical Mediterranean (Papadakis, 1966). During the crop seasons in this plot, the average temperatures were $16.1^{\circ} \mathrm{C}$ and $16.7^{\circ} \mathrm{C}$ in 2011 and 2012, respectively. The average maximum temperatures were $20.9^{\circ} \mathrm{C}$ and $22.2^{\circ} \mathrm{C}$, respectively, and the average minimum temperature was $11.5^{\circ} \mathrm{C}$ in both years. The total rainfall that was recorded during the autumn season was $75 \mathrm{~mm}$ in 2011 and $58 \mathrm{~mm}$ in 2012.

\subsection{Data gathering}

During the experimental crop seasons of each plantation, four sample subparcels with an area of $1.8 \mathrm{~m}^{2}(1.8 \mathrm{~m} \times 1.0 \mathrm{~m})$ were delimitated by frames in each plot, being representative of the culture and randomly distributed, avoiding the edge of the plot to avoid the edge effect. From the first day of transplantation and at intervals of two to three days, plant growth was monitored by measuring the average root depth of lettuce plants and the PGC for each sample subparcel.

Because lettuce plants have a tap root system, several perforations were performed in the terrain for each plot to identify the primary root and measure its length, considering this value as the root depth. To determine the PGC for each sample plot, the vertical canopy was photographed using a digital compact camera (Coolpix S3300, Nikon, Japan) that was equipped with a charge-coupled device (CCD) sensor (resolution 16.0 megapixels; focal length $27.6 \mathrm{~mm}$ ). This camera was mounted on a tripod at a fixed height of $1.40 \mathrm{~m}$ above ground level. To match the PGC, photographs were always taken at solar noon. It was recommended to take several photographs of each subparcel and to later select the best shot (i.e., a photograph that does not show luminosity defects or concavity and is correctly framed).

After recording photographs of the four sample subparcels and selecting the best shots, the images were digitally preprocessed such that only the interior of the frame was left. For this purpose, any commercially available photo editing software can be used. Because the method proposed here calculates the green cover as a percentage (rather than the number of pixels), the final resolution of the images will not affect the results; this method is therefore scale-invariant. In other words, because the percentage divides the number of vegetation pixels by the total number of pixels in the image, this proportion will remain the same if the image is scaled.

The preprocessed images were later processed using ENVI ${ }^{\circledR}$ (Environment for Visualising Images) software (Research System Inc., Boulder, CO, USA), which provides an easy-to-use environment to display and analyse images of any size and any type of data.

The first phase was the segmentation of the image to discriminate between the soil (beige) and the vegetation (green) (see Fig. 1). The software permitted to define these two classes and select the regions of interest (ROIs) in the image that pertained to the same class. Once these ROIs were defined, the image was segmented using a maximum likelihood supervised classification of the image based on the defined ROIs. After segmentation, the number of pixels corresponding to the vegetation $(V)$, soil $(S)$ and totality $(T)$ of 

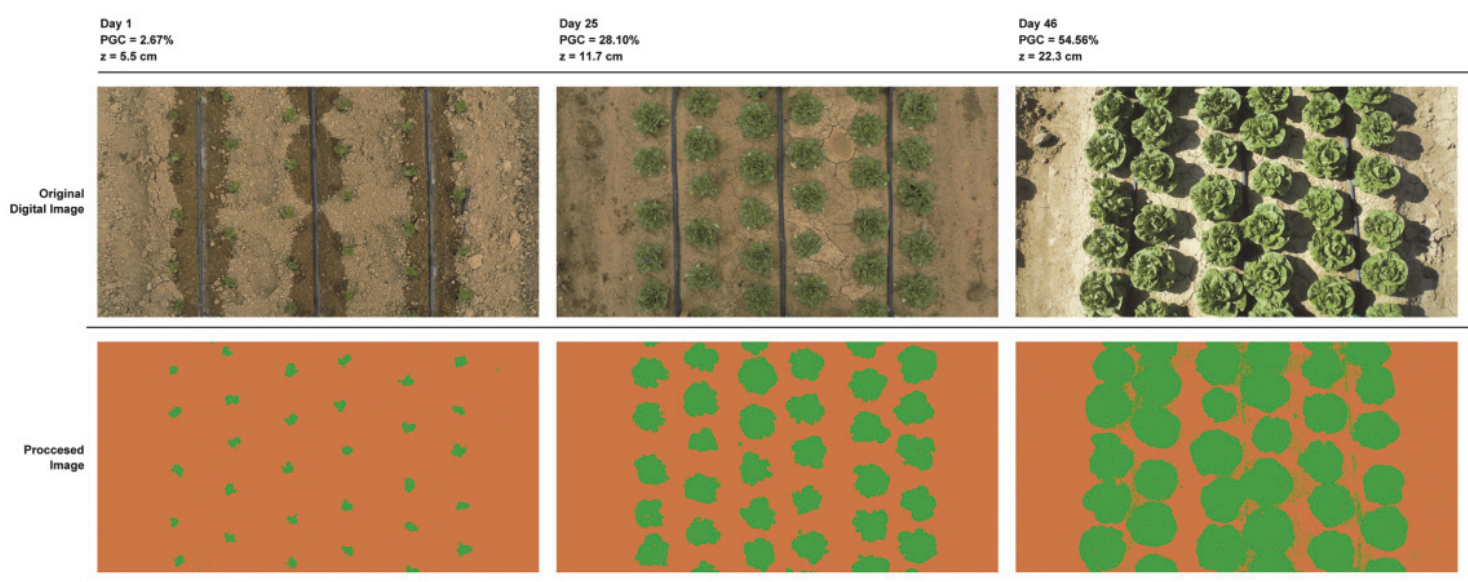

Fig. 1. Sample results that were obtained using the image-processing software.

the image were obtained and used to calculate the PGC as the V/T ratio. Once the PGC was obtained for each subparcel, the average value of the four subparcels was calculated for each sample day. A more detailed description of the digital image-processing-based method is provided by Fernández-Pacheco et al. (2014).

\subsection{Obtaining approximation functions and comparison statistics}

During 2011, two crop seasons were monitored, one in spring and another in autumn. This monitoring permitted the tracking of the evolution of the PGC and root depth ( $z$ ), as shown in Fig. $2 a$ and $b$. As shown, the two parameters present very similar growth curves, indicating a good correlation. Therefore, it is possible to define a function to estimate the root depth from the PGC parameter. For this purpose, the values that were obtained during the two crop seasons of 2011 were used, and different approximation functions were analysed, including logarithmic, exponential, logistic, and Gompertz models.

These models were adjusted using the Solver tool of Excel (Microsoft Corporation, Redmond, WA, United States), which solves linear and non-linear optimisation problems that may include integer restrictions on the decision variables. The actual root depth values were compared to the root depth values that were predicted by the models using a simple linear regression and statistics given by Willmott (1982). The root mean square error (RMSE) was calculated as follows:

$\mathrm{RMSE}=\sqrt{\frac{1}{n} \sum\left(P_{i}-O_{i}\right)^{2}}$

where $n$ is the number of cases, and $P_{i}$ and $O_{i}$ are the model predicted and observed root depth values, respectively. Furthermore, the index of agreement (IA) was computed to describe the differences between the compared values as follows:

$$
\mathrm{IA}=1-\frac{\sum\left(P_{i}-O_{i}\right)^{2}}{\sum \mid\left(P_{i}-O_{i}|+| O_{i}-O_{\text {ave }} \mid\right)^{2}}
$$

where $O_{\text {ave }}$ is the average value for variable 0 . The optimum selected solution corresponds to the model with the minimum RMSE and maximum IA values.

\section{Results and discussion}

The evolution of the PGC and root depth parameters during the spring and autumn crop seasons of 2011 is shown in Fig. 2. In both cases, the PGC parameter increased almost linearly to values greater than $60 \%$ at harvest (63.2\% in spring and $68.2 \%$ in autumn). Moreover, the root depth parameter described a similar growth, not exceeding the average soil depth of $40 \mathrm{~cm}$ and reaching $20.2 \mathrm{~cm}$ in spring and $28.5 \mathrm{~cm}$ in autumn, which were the expected values under conditions of drip irrigation and clay-loam soil (Rincón, 2005). The correlation of the PGC and root depth values was also investigated. For this purpose, different approximation functions were analysed. During the spring crop season of 2011, the best results were obtained using the logarithmic approximation model (Eq. (3)), where $y=z(\mathrm{~cm}), x=$ PGC (\%), $a=5.370$, and $b=-2.602$.

$$
y=a \cdot \ln (x)+b
$$

To evaluate the performance of this equation, the measured root depth and the root depth that was estimated using Eq. (3) were compared (Fig. 3a). A linear regression analysis was also performed, yielding a slope of the linear regression line very close to $1(0.981)$ and a squared correlation coefficient of 0.981 (Fig. 4a). The obtained RMSE was $0.649 \mathrm{~cm}$, and the index of agreement was 0.995 , demonstrating that the difference between the actual values and the values that were predicted by the model was minimal.

The equation that was obtained for the spring crop season (Eq. (3)) was subsequently used in the autumn season to estimate the root depth. In this case, the actual root depth values were overestimated by the model until the PGC reached $47.5 \%$ (day 39), after which the model began to underestimate the actual root depth (Fig. 3b). The linear regression analysis that was conducted between the measured root depth values and the root depth values that were estimated using Eq. (3) yielded a squared correlation coefficient of 0.746 and a slope of the linear regression line of 0.571 (Fig. 4b). In this case, the goodness of fit was lower, obtaining an RMSE of $4.316 \mathrm{~cm}$ and an index of agreement of 0.885 .

Considering these results, a different approximation function to correlate the root depth and PGC values for the autumn crop season was searched. In this case, the best results corresponded to 
G Model AGWAT-4031; No. of Pages 7

\section{ARTICLE IN PRESS}

D. Escarabajal-Henarejos et al. / Agricultural Water Management xxx (2014) $x x x-x x x$
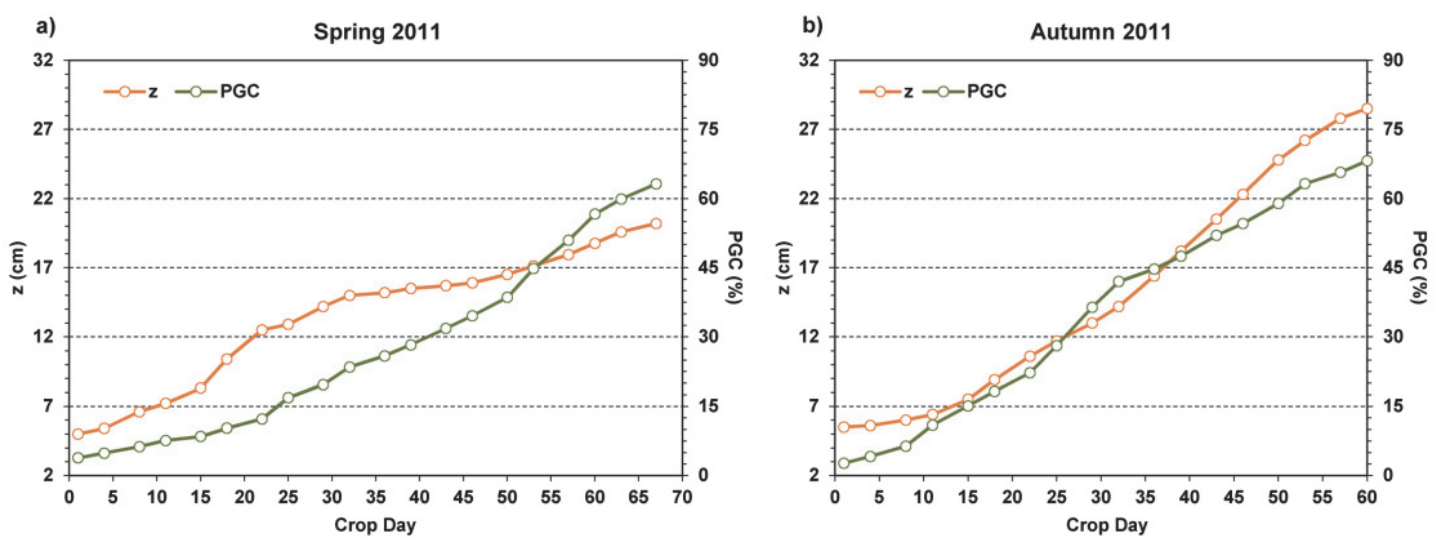

Fig. 2. Evolution of the root depth (z) and percentage of ground cover (PGC) during the 2011 crop seasons: (a) spring and (b) autumn.
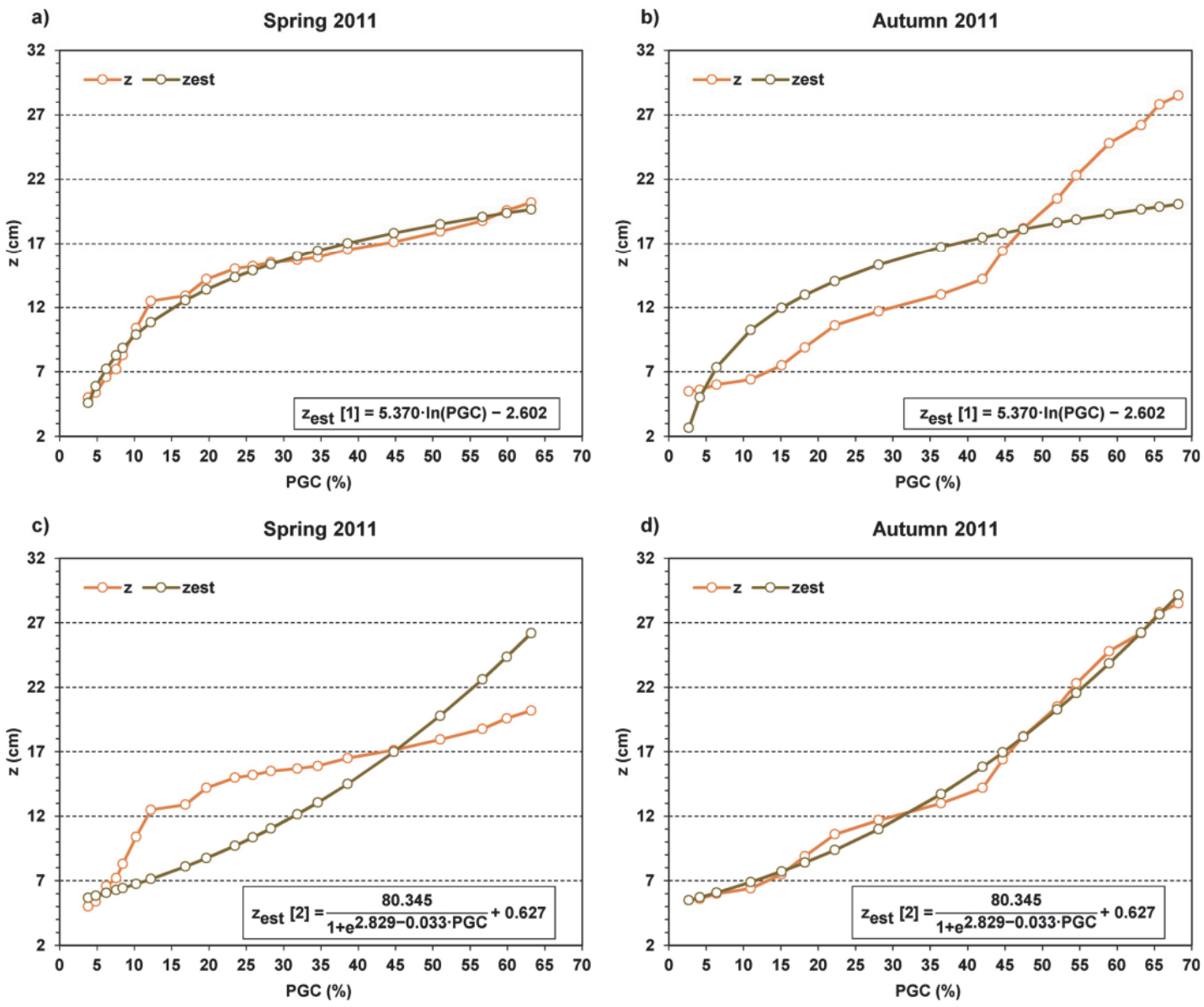

Fig. 3. Estimated $\left(z_{\text {est }}\right)$ and actual $(z)$ root depth values during the 2011 crop seasons using logarithmic $\left(z_{\text {est }}[1]\right)$ and logistic $\left(z_{\text {est }}[2]\right)$ models.

Please cite this article in press as: Escarabajal-Henarejos, D., et al., Methodology for obtaining prediction models of the root depth of lettuce for its application in irrigation automation. Agric. Water Manage. (2014), http://dx.doi.org/10.1016/j.agwat.2014.10.012 
G Model

\section{ARTICLE IN PRESS}

D. Escarabajal-Henarejos et al. / Agricultural Water Management xxx (2014) $x x x-x x x$
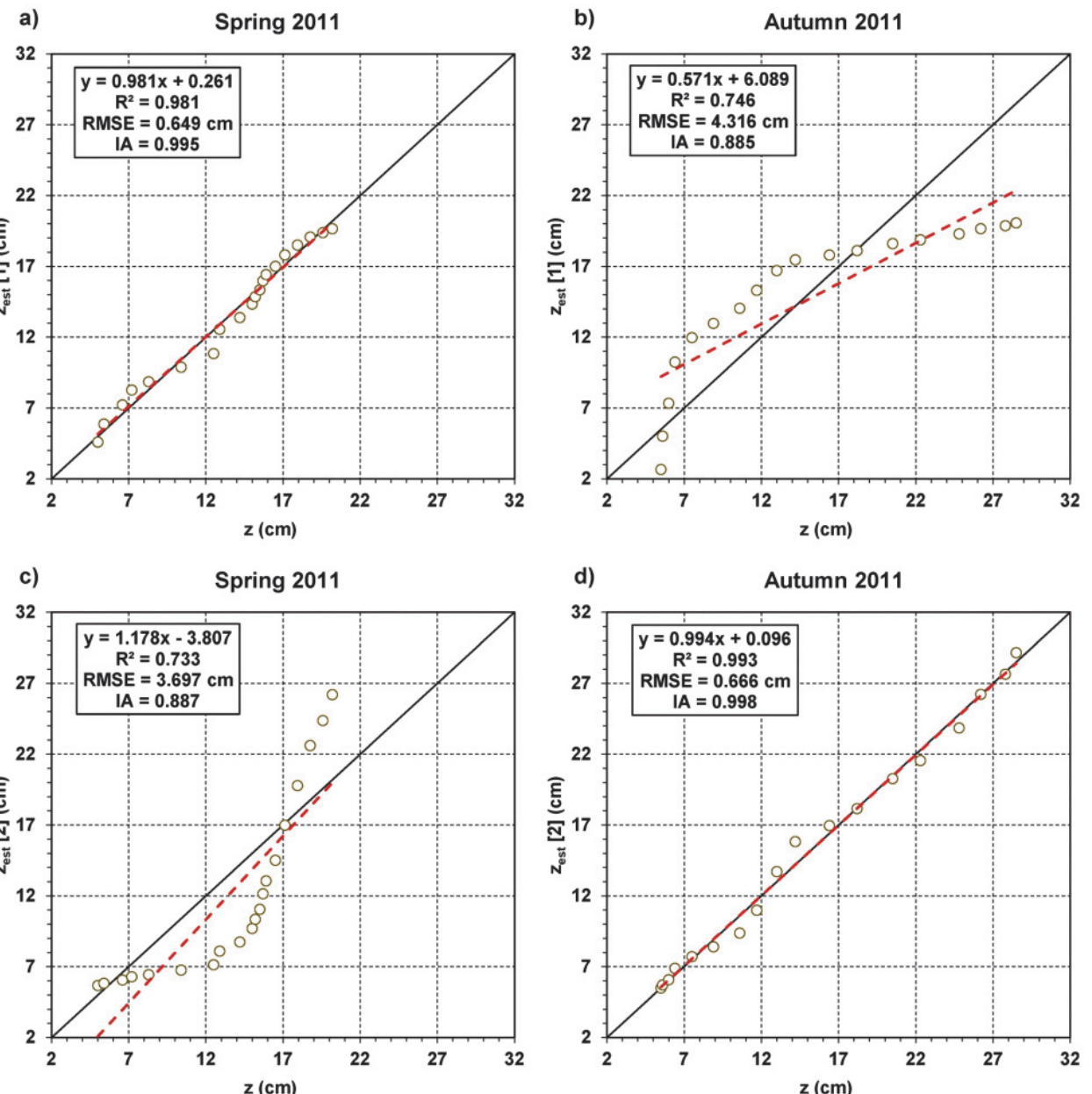

Fig. 4. Linear regression analysis between the actual root depth values $(z)$ and the values that were estimated using the logarithmic model $\left(z_{\text {est }}[1]\right)$ and the logistic model ( $\left.z_{\text {est }}[2]\right)$ for the 2011 crop seasons.

the logistic growth model (Eq. (4)), where $y=z(\mathrm{~cm}), x=$ PGC (\%), $a=80.345, b=2.829, c=-0.033$, and $d=0.627$.

$y=\frac{a}{1+e^{b+c \cdot X}}+d$

To evaluate the performance of this equation, the measured root depth values and the root depth values that were estimated using Eq. (4) were compared (Fig. 4d). A linear regression analysis was also conducted, yielding a slope of the linear regression line very close to $1(0.994)$ and a squared correlation coefficient of 0.993 . The obtained RMSE in this case was $0.666 \mathrm{~cm}$, and the index of agreement was 0.998 , demonstrating that the difference between the actual values and the values that were predicted by the model was minimal.

The equation that was obtained for the autumn crop season (Eq. (4)) was also analysed in the spring season to estimate the root depth. In this case, the actual root depth values were underestimated by the model until the PGC reached $44.8 \%$ (day 53 ), after which the model began to overestimate the actual root depth (Fig. 3c). The linear regression analysis that was conducted between the measured root depth values and the root depth values that were estimated using Eq. (4) yielded a squared correlation coefficient of 0.733 and a slope of the linear regression line of 1.178 (Fig. 4c). The obtained RMSE was 3.697, and the index of agreement was 0.887 , demonstrating that the root depth during the spring crop season was better estimated by Eq. (3) than by Eq. (4).

According to the described results, it can be further concluded that the proposed methodology has a strong seasonal component that determines the optimum type of prediction function. While in the spring crop, the logarithmic model achieves the best fit between the PGC parameter and the root depth, a different result is obtained in the autumn crop, in which the logistic model yields the best relation between both variables. Nevertheless, the proposed methodology is based on the dependence between the PGC and the root depth as observed in both of the tested annual seasons, obtaining determination coefficients very close to unity and RMSE values that were always less than $0.900 \mathrm{~cm}$. 
G Model AGWAT-4031; No. of Pages 7

\section{ARTICLE IN PRESS}

D. Escarabajal-Henarejos et al. / Agricultural Water Management $x x x(2014) x x x-x x x$
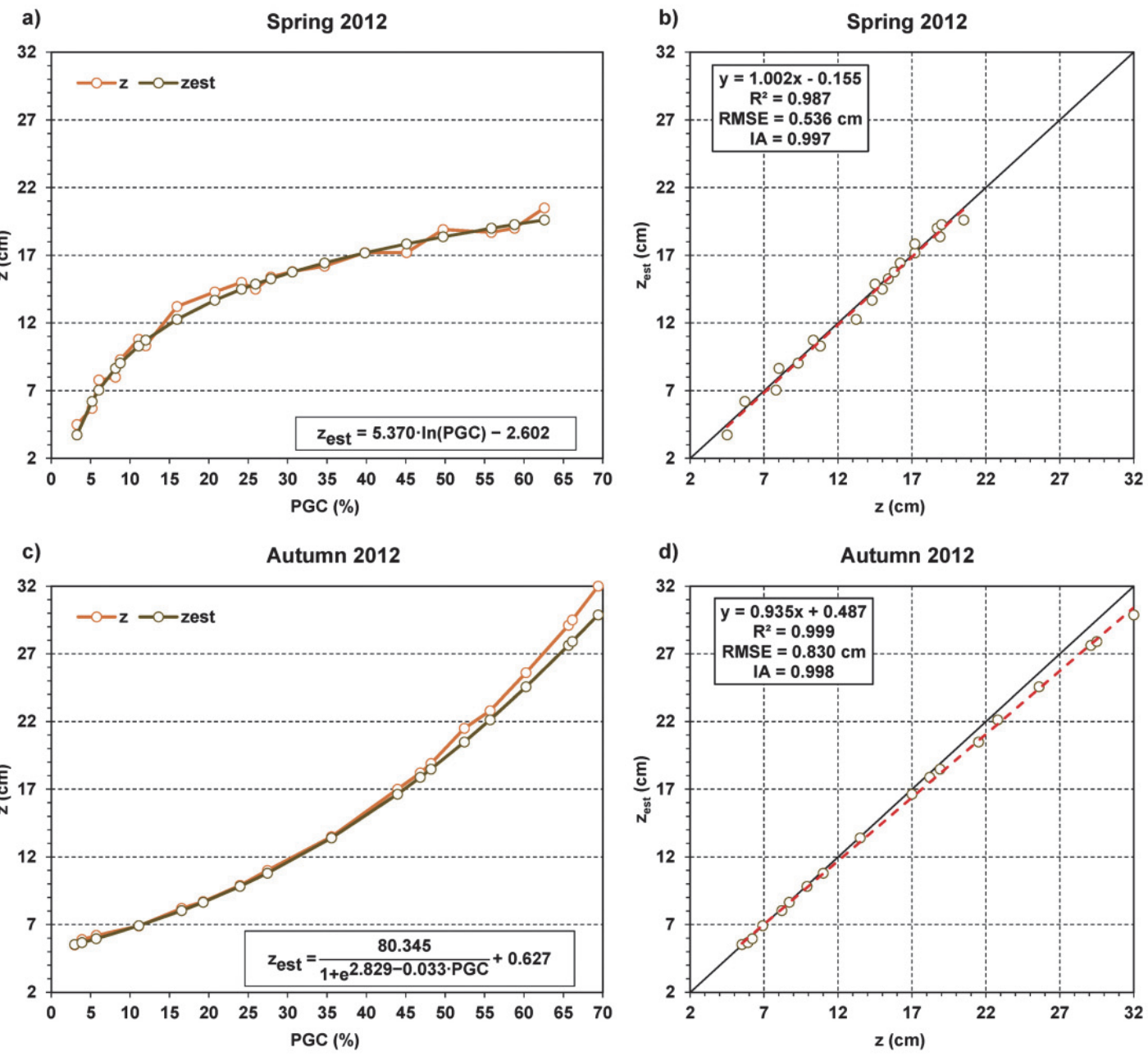

Fig. 5. Relationship between the percentage of ground cover (PGC) and the actual and estimated root depth values for the 2012 crop seasons: (a) spring and (c) autumn; linear regression analysis between the actual $(z)$ and estimated $\left(z_{\text {est }}\right)$ root depth values that were obtained with (b) a logarithmic model for the spring crop season and (d) logistic model for the autumn crop season.

To demonstrate the validity of the proposed methodology, the equations that were obtained during the 2011 crop seasons were applied under similar conditions and in the same locations for the 2012 crop seasons (as shown in Fig. 5). A linear regression analysis that was performed on both of the crops reported a slope regression line very close to 1 ( 1.002 and 0.935 for spring and autumn, respectively) and a squared correlation coefficient of 0.987 and 0.999 respectively (see Fig. 5). The obtained RMSE values were $0.536 \mathrm{~cm}$ and $0.830 \mathrm{~cm}$, respectively, which were very similar to those that were obtained for the 2011 crop seasons.

\section{Conclusions}

This paper presents a new methodology for estimating the root depth of lettuce crops based on digital photographs of the vegetation cover during its two crop cycles in southeast Spain. For this calculation, the PGC parameter is first obtained by processing digital photographs using ENVI ${ }^{\circledR}$, and then the PGC value is correlated with the root depth. During the spring crop season, this methodology obtained a logarithmic equation to model the relationship between these parameters; a squared correlation coefficient of 0.987 was obtained in 2012. For the autumn crop season, a logistic equation produced the best predictions; a squared correlation coefficient of 0.999 was obtained in 2012, demonstrating the validity of this methodology.

The real and estimated root depth values that were proposed by the obtained equations were compared for the four seasons (two in 2011 and two in 2012). The results demonstrated a strong correlation between the PGC parameter and root depth. Therefore, the proposed methodology relies on this relationship, considering the strong seasonal component that conditions the type of equation that yields the best predictions depending on the crop season.

The proposed methodology permits the development of more-accurate algorithms for intelligent irrigation systems. This 


G Model
AGWAT-4031; No.of Pages 7

D. Escarabajal-Henarejos et al. / Agricultural Water Management $x x x$ (2014) $x x x-x x x$

methodology is essentially an analytical tool with application in automatic watering systems that provides an important optimisation of the economic benefit in lettuce culture by reducing wate consumption. Knowledge of the root depth during each stage of the crop development provides a way to adjust irrigation management practices to maintain optimal moisture conditions in the root zone of the plants.

\section{Acknowledgements}

This work was supported by the "Seneca Foundation" (Murcia Regional Authority, Spain) through the project ref 08729/PI/08 and by the Spanish MINECO under grant TIN2012-38341-C04-03.

\section{References}

Allen, R.G., Pereira, L.S., Raes, D., Smith, M., 1998. Crop evapotranspiration: guidelines for computing crop water requirements. In: FAO Irrigation and Drainag Papers. FAO, Rome, Italy, pp. 328

Allen, R.G., Wright, J.L., Pruitt, W.O., Pereira, L.S., 2007. Water requirements. In: Hoffen, R.G., Wright,, J.L., Pruitt, W.O., Pereira, L.S., 2007. Water requirements. In: Hof man, G.j., Evans, R.G., Jensen, M.E., Martin, D.L., Elliot, R.L. (Eds.), Design an MI, pp. 208-288.

Baillie, I.C., 2001. Soil survey staff 1999, soil taxonomy. Soil Use Manage. 17 (1) $57-60$.

Boote, K.J., Jones, J.W., Hoogenboom, G., White, J.W., 2010. The role of crop systems simulation in agriculture and environment. Int. J. Agric. Environ. Inf. Syst. $41-54$

Congling, W., Guanghui, T., Changying, L., 2005. Application and validation of computer vision based nondestructive measurement system for cucumber seedlin growth conditions. Trans. Chin. Soc. Agric. Eng. 21 (4), 109-112.

De Medeiros, G.A., Arruda, F.B., Sakai, E., Fujiwara, M., 2001. The influence of crop canopy on evapotranspiration and crop coefficient of beans (Phaseolus vulgaris L.). Agric. Water Manage. 49 (3), 211-224.

Domínguez, A., Tarjuelo, J., de Juan, J., López-Mata, E., Breidy, J., Karam, F., 2011. Deficit irrigation under water stress and salinity conditions: the MOPECO-salt model. Agric. Water Manage. 98, 1451-1461.

Eilers, V.H.M., Carter, R.C., Rushton, K.R., 2007. A single layer soil water balance mode for estimating deep drainage (potential recharge): an application to cropped and in semi-arid North-east Nigeria. Geoderma 140 (1), 119-131.

Fernández-Pacheco, D.G., Escarabajal-Henarejos, D., Ruiz-Canales, A., Conesa, J., Molina-Martínez, J.M., 2014. A digital image-processing-based method fo determining the crop coefficient of lettuce crops in the southeast of Spain. Biosyst. Eng. 117, 23-34.

Grant, O.M., Davies, M.J., Longbottom, H., Harrison-Murray, R., 2012. Evapotranspiration of container ornamental shrubs: modelling crop-specific factors for diverse range of crops. Irrigation Sci. 30 (1), 1-12.

Griffin, T.S., Johnson, B.S., Ritchie, J.T., 1993. A simulation model for potato growt and development: Substor-potato Version 2.0. Department of Agronomy an Soil Science, College of Tropical Agriculture and Human Resources, University of Hawaii, Honolulu, Hawaii, USA.
Haboudane, D., Miller, J.R., Pattey, E., Zarco-Tejada, P.J., Strachan, I.B., 2004. Hyperspectral vegetation indices and novel algorithms for predicting green LAI of crop canopies: modeling and validation in the context of precision agriculture. Remote Sens. Environ. 90, 337-352.

Hanson, B.R., May, D.M., 2006. Crop coefficients for drip-irrigated processing tomato. Agric. Water Manage 81, 381-399.

Hsiao, T.C., Heng, L., Steduto, P., Rojas-Lara, B., Raes, D., Fereres, E., 2009. AquaCrop - the FAO crop model to simulate yield response to water: III. Parameterization and testing for maize. Agron. J. 101, 448-459

López-Urrea, R., Martín de Santa Olalla, F., Montoro, A., López-Fuster, P. 2009. Single and dual crop coefficients and water requirements for onion (Allium cepa L.) under semiarid conditions. Agric. Water Manage. 96 (6) 1031-1036.

Ma, Y., Feng, S., Song, X., 2013. A root zone model for estimating soil water balance and crop yield responses to deficit irrigation in the North China Plain. Agric

Mackerron, D.K.L., 2007. Mathematical models of plant growth and development. In: Vreugdenhil, D., Bradshaw, J., Gebhardt, C., Govers, F., Mckerron, D.K.L., Taylor, M.A., Ross, H.A. (Eds.), Potato Biology and Biotechnology Advances and Perspectives. Elsevier, Amsterdam, The Netherlands, pp Mize, J.H., Cox, J.G., 1968. Essentials of Simulation. Prentice Hall, Englewood Cliffs, N.J.

Nishat, S., Guo, Y., Baetz, B.W., 2007. Development of a simplified continuous simulation model for investigating long-term soil moisture fluctuations. Agric. Water lation model for investion

Panigrahi, B.. Panda, S.N., 2003. Field test of a soil water balance simulation model. Agric. Water Manage. 58 (3), 223-240.

Papadakis,J.1966. Climates of the world and their agricultural potentialities, Buenos Aires., pp. 174.

Rincón, L..,2005. La fertirrigación de la lechuga iceberg. Instituto Murciano de Investigación y Desarrollo Agrario y Alimentario, Murcia.

Sammis, T., Sharma, P., Shukla, M., Wang, J., Miller, D., 2012. A water-balance dripirrigation scheduling model. Agric. Water Manage 113, 30-37.

Shang S, Mao, X, 2006. Application of a simulation based ontimization model for winter wheat irrigation scheduling in North China. Agric. Water Manage. 85 (3), 314-322.

Steduto, P. Hsiao, T.C. Raes, D., Fereres, E., 2009. AquaCrop - the FAO crop model to (a) J. 101, 426-437.

Stöckle, C.O., Donatelli, M., Nelson, R., 2003. CropSyst, a cropping systems simulation model. Eur. J. Agron. 18, 289-307.

Taylor, H., Brar, G., 1991. Effect of soil compaction on root development. Soil Till. Res. 19, 111-119.

Xiao, L., Tingfangzi, T., Suiliang, H., Yang, L., 2011. Image processing based nondestructive method for measuring growth of constructed wetland plants. In: Proc. 5th iCBBE, pp. 1-4.

Xu, X.G., Wang, J.H., Li, C.J., Song, X.U., Huang, W.J., 2010. Estimating growth height of winter wheat with remote sensing. In: Proc. SPIE 7824 Remote Sensing for Agriculture, Ecosystems, and Hydrology, vol. XII, 782428.

Whisler, F.D. Acock, B., Baker, D.N., Fye, R.E., Hodges, H.F., Lambert, J.R., 1986. Crop simulation models in agronomic systems. Adv. Agron. 40, 141-208.

Willmott, C.J.. 1982. Some comments on the evaluation of model performance. Bull. Am. Meteorol. Soc. 63 (11), 1309-1313,

Please cite this article in press as: Escarabajal-Henarejos, D., et al., Methodology for obtaining prediction models of the root depth of lettuce for its application in irrigation automation. Agric. Water Manage. (2014), http://dx.doi.org/10.1016/j.agwat.2014.10.012 



\subsection{Publicación 5}

\section{Study and comparison of color models for automatic image analysis in irrigation management applications}

G. García-Mateos ${ }^{1}$, J.L. Hernández-Hernández ${ }^{3}$, D. Escarabajal-Henarejos ${ }^{2}$, S. JaénTerrones $^{1}$, J.M. Molina-Martínez ${ }^{2}$

${ }^{1}$ Departamento de Informática y Sistemas. Facultad de Informática. Universidad de Murcia, Campus Universitario de Espinardo, 30100 Murcia.

${ }^{2}$ Grupo de Investigación en Ingeniería Agromótica y del Mar. Universidad Politécnica de Cartagena, $\mathrm{P}^{\mathrm{o}}$ Alfonso XIII 52, 30203 Cartagena, Murcia.

${ }^{3}$ Unidad Académica de Ingeniería. Universidad Autónoma de Guerrero, Av. Lázaro Cárdenas s/n, Ciudad Universitaria, Chilpancingo, Guerrero, México.

\section{RESUMEN}

Las técnicas de procesamiento de imágenes y visión artificial están siendo cada vez más utilizadas de forma exitosa en aplicaciones agromóticas para la gestión de cultivos y procesos agroalimentarios. Es bien conocido que las imágenes pueden aportar información muy valiosa sobre el estado de crecimiento de las plantas, las enfermedades carenciales, la maduración de los frutales, la aparición de plagas y malas hierbas, etc. Las técnicas basadas en análisis de color son fundamentales en este dominio, al permitir clasificar y caracterizar de forma precisa, robusta y eficiente las distintas regiones de las 
imágenes. En el ámbito de la visión artificial se han propuesto diversos modelos de color, entre los que podemos destacar: RGB, rgb, XYZ, L*a*b*, L*u*v*, HSV, HLS, YCrCb, YUV, I1I2I3 y TSL. Al mismo tiempo, existen diferentes formas de modelar las distribuciones de probabilidad de color. El método más habitual es el modelado no paramétrico mediante histogramas; esto abre, a su vez, diferentes alternativas para representar un color: el número de canales a usar, qué canales usar, y el tamaño de los histogramas. Partiendo de un conjunto muy amplio y variado de imágenes de plantaciones de lechuga (Lactuca sativa L.) -clasificadas previamente de forma manual en zonas de suelo y zonas de cultivo-, se ha llevado a cabo un estudio exhaustivo y sistemático de la forma óptima de modelar el color en problemas de clasificación de plantas. Los resultados experimentales demuestran la superioridad en los modelos que separan luminancia y crominancia. En particular, el espacio de color $\mathrm{L}^{*} \mathrm{a} \mathrm{b}^{*}$ ofrece los mejores resultados con el canal a*, con un porcentaje de acierto en la clasificación del 99,2\%. Además, etapas de procesamiento adicionales pueden lograr mejorar los resultados hasta un acierto del 99,5\% tardando solo 0,3 segundos por imagen en un ordenador portátil. Estos resultados pueden ser aplicados para reducir el consumo de agua mediante la optimización de la exactitud y la eficiencia en el análisis automático de imágenes de cultivos.

\section{INTRODUCCIÓN}

El análisis automático de imágenes digitales de cultivos es un campo de investigación muy activo y atractivo en el que confluyen la visión por computador y la agromótica (Cubero et al., 2011). El color es una característica esencial en muchos problemas de este dominio, aunque no toda la visión artificial se basa en el uso de color; de hecho, existe una amplia variedad de técnicas alternativas que han sido usadas en aplicaciones agromóticas, como el análisis de bordes, formas, texturas, etc. Sin embargo, el manejo de color presenta grandes ventajas en los problemas que nos ocupan por su baja dimensionalidad, alta expresividad y facilidad de procesamiento. El color puede servir para discriminar de forma precisa y eficiente los píxeles, o zonas de una imagen, que corresponden al suelo o a vegetación. De esta forma, el resultado de la clasificación en suelo o planta puede usarse para la medición del coeficiente de cobertura vegetal (Fernández-Pacheco et al., 2014). Este parámetro tiene un papel clave en la monitorización de cultivos y es ampliamente aplicado para determinar las necesidades hídricas de los cultivos usando la metodología FAO-56 (Allen et al., 1998). 
El problema de la segmentación automática suelo/planta ha sido ampliamente estudiado por diversos investigadores, como puede comprobarse en dos revisiones recientes del estado del arte (Lin et al., 2013; McCarthy et at., 2010). En la mayoría de estos trabajos la clasificación se hace usando diversas técnicas como umbralización, discriminantes lineales, modelos de gaussianos, lógica difusa, redes neuronales, y otros; pero el espacio de color es fijado de antemano, y se echan en falta estudios comparativos sobre la efectividad de diversos modelos de color en plantas. Sin embargo es habitual encontrar ese tipo de trabajos comparativos otros dominios. Por ejemplo, Shih y Lui (2012) evaluaron comparativamente 12 espacios de color en aplicaciones de procesamientos de caras, y llegaron a la conclusión de que los espacios óptimos son YUV y YIQ; Luszczkiewicz-Piatek (2014) estudia la elección del espacio de color para la recuperación de imágenes en grandes bases de datos; el color se representa con modelos de mezcla de gaussianas y se analizan 11 espacios de color. Por su parte, Terrillon y Akamatsu (2000) introdujeron el espacio TSL, y se compararon 9 espacios en la detección de caras.

En consecuencia, el objetivo de este trabajo es realizar un estudio completo y exhaustivo, con el propósito de seleccionar el espacio de color óptimo y la forma más efectiva de representar las distribuciones de color para los problemas de clasificación en el dominio agromótico, y en concreto para la segmentación automática de plantas en imágenes.

\section{MATERIALES Y MÉTODOS}

\subsection{Imágenes utilizadas para la experimentación}

La imágenes utilizadas para los experimentos corresponden a cultivos de lechuga (Lactuca sativa L.), en la comarca del campo de Cartagena (37\%46'N, $\left.0^{\circ} 58^{\prime} \mathrm{O}\right)$. Se realizaron dos series de fotografías. La primera serie tuvo lugar entre octubre de 2010 y enero de 2011, y la segunda entre octubre y diciembre de 2012. En cada una de estas series se hizo un seguimiento fotográfico de 4 parcelas diferentes, a intervalos de entre 2 y 4 días. Las imágenes fueron tomadas con una cámara digital compacta Nikon modelo Coolpix S3300 a alta resolución, y presentan una vista cenital del terreno, como muestra la Fig. 4.1. 


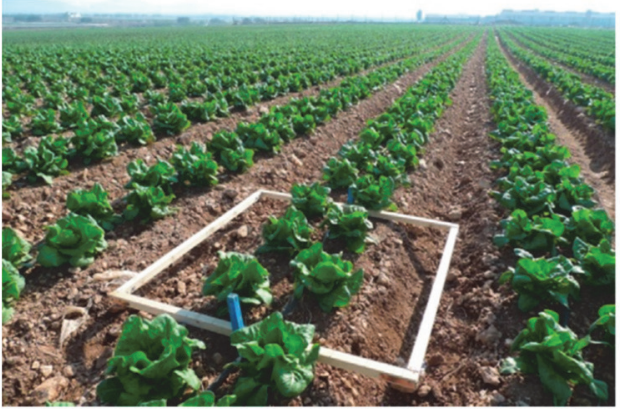

a)

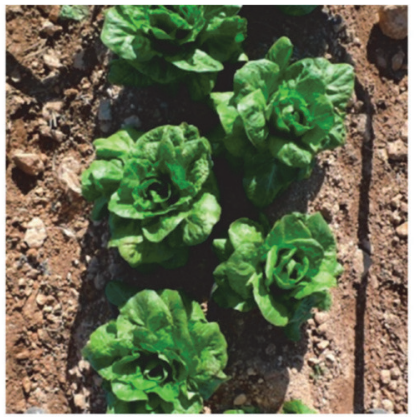

b)

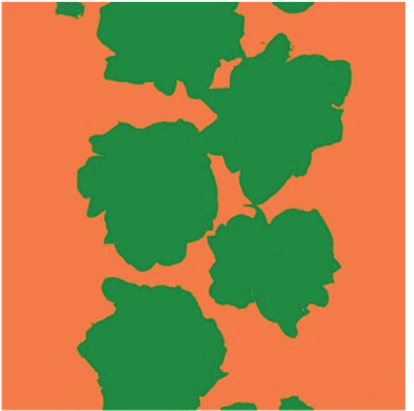

c)

Fig. 4.1. Imágenes usadas para la experimentación. a) Una visión general de una de las parcelas con el área de interés señalada. b) Ejemplo de una fotografía de la parcela. c) La misma fotografía después de la clasificación con ENVI en suelo y planta.

Las imágenes fueron recortadas y normalizadas respecto a un patrón rectangular (situado físicamente en el suelo); como resultado, las imágenes de la primera serie tienen una resolución de 1500x1500 píxeles y 3600x2000 píxeles la segunda. Después fueron segmentadas manualmente por expertos usando el software ENVI ${ }^{\circledR}$ (Environment for Visualizing Images) versión 4.0, obteniendo imágenes binarias donde cada píxel es clasificado como suelo o planta (Fig. 4.1c). La primera serie contiene un total de 108 fotografías y la segunda serie 61 . En total hay 169 imágenes de alta calidad, que presentan una gran variabilidad en cuanto a la iluminación, porcentaje de cobertura vegetal, aparición de sombras, humedad del suelo, tipos de suelo, etc. En los experimentos, la primera serie fue utilizada para el entrenamiento de los modelos de color, y la segunda para su validación experimental.

\subsection{Clasificación y representación del color}

El color concreto de un píxel del suelo, o de las plantas, puede entenderse como un suceso estocástico dentro del espacio n-dimensional definido por el espacio de color usado. En el caso del suelo, la distribución de probabilidad del color está determinada por el tipo y composición del suelo, la iluminación en el momento de tomar la foto y los parámetros propios de la cámara, como el balance de blancos; de forma similar ocurre con el color de la cobertura vegetal, donde la clorofila da lugar a la predominancia de los tonos verdes. Supongamos conocidas las funciones de distribución probabilidad del color del

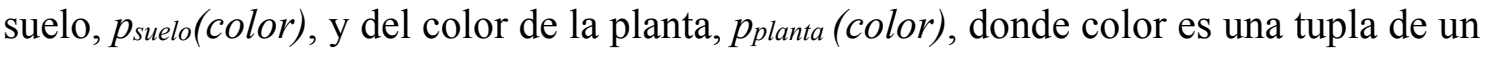
espacio de color cualquiera. Considerando equiprobables las probabilidades a priori de suelo y de planta, la probabilidad de que un píxel, color, concreto sea de planta o de suelo, puede calcularse de forma sencilla mediante la regla de Bayes, dada por las ecuaciones: 


$$
\begin{gathered}
P(\text { suelo } / \text { color })=\frac{p_{\text {suelo }}(\text { color }) \times P(\text { suelo })}{p_{\text {planta }}(\text { color }) \times P(\text { planta })+p_{\text {suelo }}(\text { color }) \times P(\text { suelo })} \\
P(\text { plantajcolor })=\frac{p_{\text {planta }}(\text { color }) \times P(\text { planta })}{p_{\text {planta }}(\text { color }) \times P(\text { planta })+p_{\text {suelo }}(\text { color }) \times P(\text { suelo })}
\end{gathered}
$$

En consecuencia, el píxel concreto es asignado a la clase de mayor probabilidad entre $P$ (planta|color) y $P($ suelo $\mid$ color $)$. De manera trivial, el problema se reduce a buscar el máximo entre planta(color) y $p_{\text {suelo }}$ (color) para cada píxel de las imágenes.

La clasificación píxel-a-píxel obtenida de esta forma se puede mejorar con la aplicación de operaciones de procesamiento local, que tienen en cuenta la vecindad de los píxeles. En concreto, se han comprobado dos opciones: reducción de la imagen por 2 usando interpolación de supermuestreo, y operaciones de morfología matemática. Mientras que la primera consigue reducir el nivel de ruido de las imágenes (al hacer un promediado de píxeles), la segunda permite limpiar el resultado de valores espurios. Además, ambas operaciones pueden aplicarse de forma combinada.

\subsection{Espacios de color analizados}

Las formas que adoptan las funciones de distribución de probabilidad, $p_{\text {suelo }} \mathrm{y}$ planta, dependen, lógicamente, del espacio de color adoptado. Cada espacio genera distintos grados de separación entre las distribuciones, afectando así la efectividad de la clasificación. Los modelos de color seleccionados para el estudio, escogidos entre los más habituales en aplicaciones de visión artificial (Luszczkiewicz-Piatek, 2014), son los siguientes:

- RGB, rgb. El espacio RGB es el más extendido en dispositivos de captura y generación de color. Se basa en un modelo de mezcla aditivo, donde cada color se forma por combinación de los tres colores primarios: rojo $(R)$, verde $(G)$, y azul (B). A partir de este modelo se define la variante normalizada rgb, que consiste en dividir los valores de $\mathrm{RGB}$ por $(\mathrm{R}+\mathrm{G}+\mathrm{B})$.

- XYZ. Es un modelo que simula la respuesta de los tres tipos de fotorreceptores de la retina (aquellos con espectros de absorción en longitudes de ondas altas, medias y bajas). La forma concreta de estos espectros de absorción fue definida por la CIE (Commission internationale de l'éclairage) en 1931. 
- HSV, HLS. En estos modelos el color se descompone en términos fácilmente interpretables como la intensidad $(\mathrm{V}, \mathrm{L})$, la saturación o pureza $(\mathrm{S})$, y el matiz de color $(\mathrm{H})$. Son modelos muy habituales en análisis y generación gráfica.

- YCrCb, YUV. Se trata de modelos orientados a compresión y trasmisión de imágenes. Se basan en la separación de un canal Y de luminancia (o intensidad luminosa), y dos canales de crominancia (o tono del color, independiente de su luminosidad). Los canales $\mathrm{Cr}$ y $\mathrm{Cb}$ corresponden, en esencia, a los canales $\mathrm{R}$ y $\mathrm{B}$ normalizados en intensidad, respectivamente.

- $\mathbf{L} * \mathbf{a}^{*} \mathbf{b} * \mathbf{L} \mathbf{u}^{*} \mathbf{v} *$. Estos modelos fueron definidos por la CIE para aplicaciones industriales del color. De forma similar a los anteriores, separan un canal de luminosidad (en este caso $\left.\mathrm{L}^{*}\right)$ y dos canales de crominancia $\left(\mathrm{a}^{*}-\mathrm{b}^{*} \mathrm{y} \mathrm{u}^{*}-\mathrm{v}^{*}\right)$. Estos últimos se definen mediante transformaciones no lineales del modelo RGB, con el fin de conseguir representaciones perceptualmente uniformes del color.

- TSL, I1I2I3. Algunos modelos han sido diseñados específicamente para ciertas aplicaciones. Por ejemplo, el modelo TSL fue creado para abordar problemas de detección de piel humana (Terrillon y Akamatsu, 2000). Por otro lado, I1I2I3 se propuso para la segmentación de color (Ohta et al., 1980), como una decorrelación de los componentes RGB usando la transformada Karhunen-Loeve.

\subsection{Representación de las distribuciones de probabilidad de color}

El modelado de funciones de densidad de probabilidad a partir de observaciones es uno de los problemas básicos en reconocimiento de patrones y en inteligencia artificial. Cuando no se conoce la distribución de los datos (o cuando ésta adopta formas muy complejas), se aplican los denominados 'métodos no paramétricos'. Dentro de ellos, los basados en histogramas son los más comunes cuando se trabaja con espacios de baja dimensionalidad. La idea consiste en calcular el histograma de los datos observados, para cada clase de interés, cuya suma es después normalizada a valor 1. Cada celda del histograma se considera una aproximación de la función de densidad en el rango correspondiente.

A su vez, existen distintas alternativas en la representación de los histogramas. En primer lugar, el número de canales a utilizar, puesto que no todos los canales son igual de útiles para el problema. Como veremos, descartar algunos canales puede producir mejores resultados que usarlos todos. En segundo lugar, tenemos el tamaño del histograma. Los 
histogramas suponen una discretización del rango de las variables estudiadas. La discretización se hace en potencias de 2 , lo que permite obtener una distribución uniforme de los valores de entrada, representados con bytes. En definitiva, para cada uno de los espacios de color, tenemos la opción de usar histogramas de un canal, dos canales o tres canales, con 16, 32, 64, 128 o 256 celdas por dimensión.

\section{RESULTADOS Y DISCUSIÓN}

Para cada una de las alternativas de representación el color (compuesta por la terna: espacio de color, canales a usar, tamaño de histograma), se ha realizado en primer lugar el entrenamiento de los modelos de color de suelo y de planta, usando las imágenes de la primera serie (un total de 108 imágenes). La Fig. 4.2 muestra los histogramas 3D de los 11 espacios de color. Sobre este resultado se ha obtenido como medida el solapamiento entre ambas distribuciones de probabilidad, calculada con la integral del área mínima de ambos histogramas.

Como segundo experimento se ha realizado una clasificación automática de las imágenes de la segunda secuencia (un total de 61 imágenes), comparando el resultado con la clasificación manual de los expertos. El valor obtenido en este caso es el porcentaje de acierto final a nivel de píxel para cada opción.

\subsection{Solapamiento entre distribuciones y acierto de clasificación}

En la Tabla 4.1 se muestran, de manera resumida, los resultados de las medidas de solapamiento y el porcentaje de acierto. El primer parámetro mide la separabilidad entre clases que ofrece cada configuración (es decir, la capacidad de diferenciar las distribuciones de las clase planta y suelo), mientras que el segundo muestra más claramente la efectividad de cada una en la segmentación.

Podemos destacar algunos hechos relevantes. Como era de esperar, el solapamiento disminuye con el número de canales y con el tamaño de los histogramas. Sin embargo, mientras que en el primer factor las reducciones son muy significativas, en el segundo no alcanzan el 30\% de reducción en los mejores casos. Además, tamaños grandes de histogramas aumentan el riesgo de 'sobreajuste' a los datos de entrenamiento. 

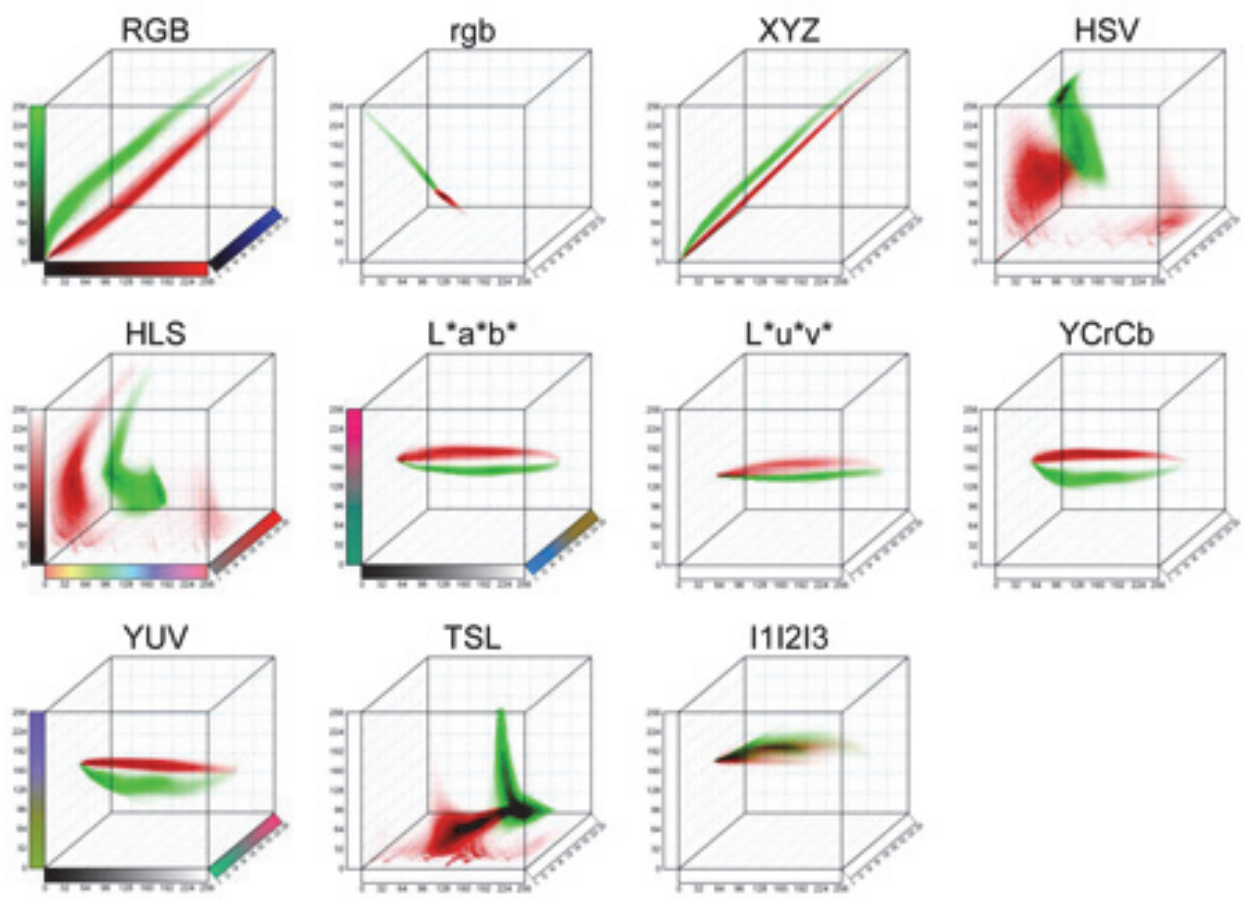

Fig. 4.2. Histogramas 3D de las clases planta (en verde) y suelo (en rojo) para los espacios de color analizados. En todos los casos, el tamaño del histograma es de 64 celdas por dimensión.

El canal que por sí solo consiguen mejores resultados es el a* del L*a*b*, con solo un $0,95 \%$ de solapamiento y un $99,2 \%$ de acierto. El mejor resultado se obtiene para 32 celdas, aunque los resultados son también muy buenos para 64 y 128. Las siguientes opciones, a más distancia, son canales I3 en I1I2I3, Cr en YCrCb, V en YUV, u* en $L^{*} u^{*} v^{*}, H$ en HSV/HLS, y T en TSL, con precisiones siempre superiores al 96\%. Por su parte, ninguno de los canales de RGB es capaz por sí solo de conseguir un solapamiento bajo, como tampoco los canales de luminosidad de los distintos espacios.

En cuanto a las combinaciones de dos canales, el principal resultado es que los menores solapamientos se producen al eliminar la luminosidad, lo que ocurre con $\mathrm{a}^{*}-\mathrm{b} *$ de L*a*b*, $\mathrm{u}^{*}-\mathrm{v}^{*}$ de L*u*v*, y Cr-Cb de YCrCb. Esto concuerda con la idea de que la crominancia aporta información de interés al problema, mientras que la luminancia es mucho menos relevante. En general, estos resultados coinciden con lo que otros autores han obtenido en otros dominios (Luszczkiewicz-Piatek, 2014; Shih y Liu, 2005), donde los espacios $\mathrm{L}^{*} \mathrm{a} \mathrm{b}^{*}$ y YCrCb están entre los más efectivos.

Finalmente, se han seleccionado algunas de las configuraciones que producen mejores resultados y sobre ellas se han aplicado las mejoras adicionales antes descritas: reducción por 2 de las imágenes; aplicación de morfología matemática; y la combinación 
de ambas. En la Fig. 4.3 se pueden ver algunos ejemplos de segmentación automática incluyendo estas mejoras. Los resultados completos pueden verse en la Tabla 4.2, que muestra también los tiempos de ejecución en un ordenador medio.

Tabla 4.1. Resultados de las pruebas de solapamiento y de la clasificación suelo/planta. Para cada espacio de color, para cada combinación de 1,2 o 3 canales se muestra: el porcentaje de solapamiento entre clases (izquierda) / el porcentaje de acierto de la clasificación (derecha).

\begin{tabular}{|c|c|c|c|c|c|}
\hline $\mathrm{RGB}$ & $\mathrm{rgb}$ & $\mathrm{XYZ}$ & HSV & HLS & $L^{*} a^{*} b^{*}$ \\
\hline R: $75 / 60,57$ & r: $16 / 80,71$ & $\mathbf{X}: 91 / 53,37$ & H: $2,1 / 96,18$ & H: $2,1 / 96,18$ & L*: $88 / 52,11$ \\
\hline G: $79 / 60,09$ & g: $4,1 / 96,05$ & $\mathbf{Y : ~ 9 0 / 5 0 , 9 ~}$ & S: $41 / 80,68$ & L: $88 / 56,2$ & $a *: 0,95 / 99,2$ \\
\hline B: $73 / 70,11$ & b: $44 / 80,52$ & Z: $79 / 66,84$ & V: $91 / 49,56$ & S: $40 / 79,88$ & $b^{*}: 28 / 85,72$ \\
\hline R-G: $0,9 / 98,22$ & $\mathbf{r - g}: 1,8 / 96,34$ & $X-Y: 0,5 / 98,9$ & H-S: $1,4 / 96,84$ & H.L: $1,2 / 97,2$ & $\mathbf{L}^{*}-\mathbf{a}^{*}: 0,5 / 99,1$ \\
\hline R-B: $63 / 69,05$ & $\mathbf{r - b}: 1,8 / 96,26$ & $X-Z: 48 / 76,45$ & H-V: $1 / 97,88$ & H.S: $1 / 97,83$ & $\mathbf{L}^{*}-\mathbf{b}^{*}: 18 / 88,3$ \\
\hline G-B: $7,7 / 93,52$ & $\mathbf{g - b}: 1,9 / 96,5$ & Y-Z: $18 / 88,39$ & S-V: $27 / 82,73$ & L-S: $27 / 82,72$ & $a^{*}-b^{*}: 0,6 / 99$ \\
\hline RGB: $0,3 / 98,48$ & rgb: $1,7 / 6,54$ & XYZ: $0,4 / 98,3$ & HSV: $0,3 / 98,9$ & HLS: $0,3 / 98,9$ & Lab: $0,4 / 98,9$ \\
\hline Luv & $\mathrm{YCrCb}$ & YUV & TSL & $|11| 2 \mid 3$ & \\
\hline L*: $88 / 51,85$ & Y: 93/50,75 & Y: $93 / 50,75$ & I1: $90 / 57,22$ & $\mathbf{T}: 2,1 / 96,29$ & \\
\hline $\mathbf{u}^{*}: 2 / 97,61$ & Cr: $2 / 96,06$ & $\mathbf{U}: 40 / 81$ & 12: $80 / 53,57$ & S: $41 / 81,03$ & \\
\hline$v^{*}: 32 / 84,89$ & Cb: $40 / 82,31$ & $V: 2 / 96,05$ & I3: $1,7 / 98,71$ & L: $93 / 48,87$ & \\
\hline $\mathbf{L}^{*}-\mathbf{u}^{*}: 1,1 / 97,9$ & Y-Cr: $1,6 / 96,5$ & Y-U: $25 / 85,4$ & |1-|12: $71 / 57,2$ & T-S: $1,5 / 96,6$ & \\
\hline $\mathbf{L}^{*}-\mathbf{v}^{*}: 10 / 92,4$ & Y-Cb: $25 / 85,5$ & Y-V: $1,6 / 96,5$ & I1-13: 0,7/98,9 & T-L: $1,1 / 97,7$ & \\
\hline $\mathbf{u}^{*}-\mathbf{v}^{*}: 0,6 / 98,7$ & CrCb: $0,4 / 99$ & U.V: $0,5 / 98,9$ & 12-13: $0,4 / 98,9$ & S-L: $14 / 88,9$ & \\
\hline Luv: $0,4 / 98,6$ & YCC: $0,3 / 98,4$ & YUV: $0,3 / 98,5$ & |11|2|3: $0,3 / 98,7$ & TSL: $0,3 / 99,1$ & \\
\hline
\end{tabular}
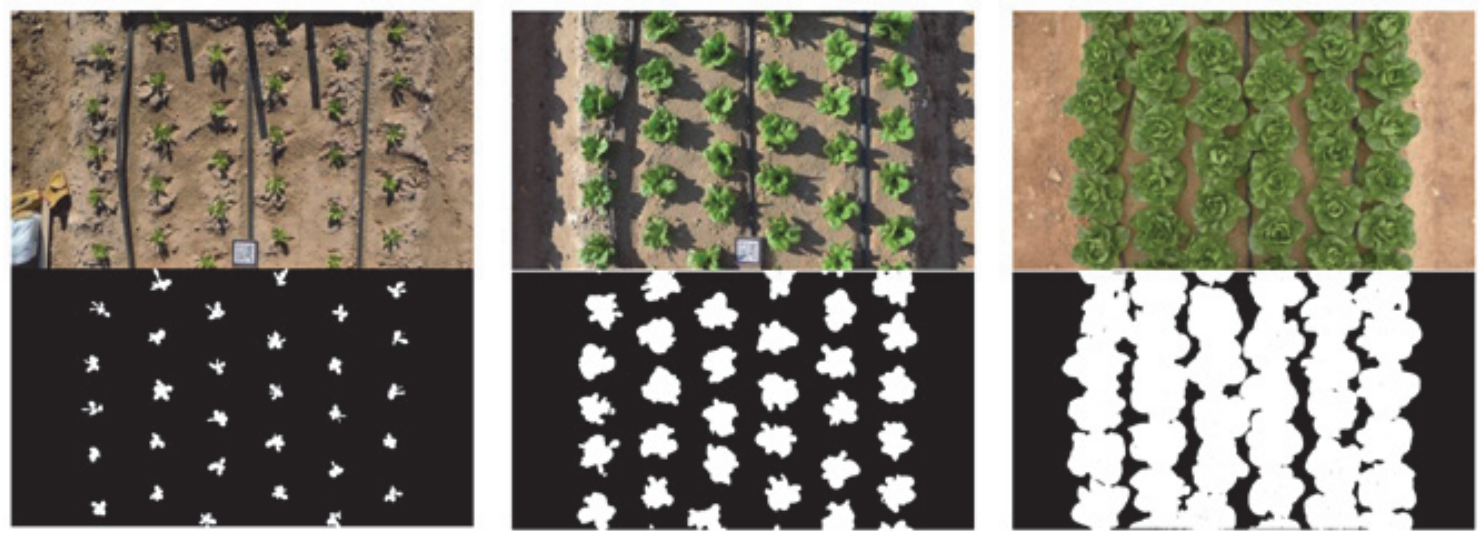

Fig. 4.3. Resultados de la segmentación automática suelo/planta, usando los canales L*-a* del espacio $\mathrm{L}^{*} \mathrm{a} \mathrm{b}^{*}$, con 64 celdas por dimensión, reducción por 2 y morfología matemática. De izquierda a derecha: los errores obtenidos respecto a la segmentación manual son: $0,03 \%, 0,11 \%$ y $0,64 \%$.

\section{CONCLUSIONES}

La elección del espacio de color óptimo, así como de la forma de representar las distribuciones probabilidad de color, es un requisito fundamental en cualquier aplicación que haga uso del color. A través de una serie de experimentos, en los que se han contrastado 385 combinaciones diferentes de espacios, canales y tamaños de histograma, 
se ha explorado de forma exhaustiva y sistemática la mejor forma de resolver el problema de la clasificación suelo/planta en el dominio agromótico.

Tabla 4.2. Tasas de error y tiempos de ejecución de la clasificación automática para los siete mejores espacios de color y canales; se muestra el error medio en \% (entre paréntesis, el tiempo medio por imagen en segundos). Original: imágenes de resolución original; Reducción: tamaño reducido a la mitad; Morfología: aplicación de los operadores de morfología abrir y cerrar; Ambas: resultados de combinar ambas mejoras.

\begin{tabular}{|c|c|c|c|c|c|c|}
\hline Espacio & Canales & Celdas & Original & Reducción & Morfologia & Ambas \\
\hline$L^{*} a^{*} b^{*}$ & $a^{*}$ & 32 & $0,84 \%(0,53 \mathrm{~s})$ & $0,80 \%(0,29 s)$ & $0,65 \%(0,56 s)$ & $0,55 \%(0,30 \mathrm{~s})$ \\
\hline$L^{*} a^{*} b^{*}$ & $L^{*}-a^{*}$ & 64 & $0,78 \%(0,58 \mathrm{~s})$ & $0,75 \%(0,30 \mathrm{~s})$ & $0,53 \%(0,61 \mathrm{~s})$ & $0,51 \%(0,31 \mathrm{~s})$ \\
\hline TSL & T-S-L & 16 & $0,87 \%(1,54 \mathrm{~s})$ & $0,77 \%(1,28 \mathrm{~s})$ & $0,57 \%(1,45 \mathrm{~s})$ & $0,60 \%(1,29 \mathrm{~s})$ \\
\hline$L^{*} a^{*} b^{*}$ & $a^{*}-b^{*}$ & 32 & $0,99 \%(0,55 s)$ & $0,94 \%(0,28 s)$ & $0,67 \%(0,58 s)$ & $0,54 \%(0,29 \mathrm{~s})$ \\
\hline$X Y Z$ & $X-Y$ & 128 & $0,87 \%(0,53 \mathrm{~s})$ & $0,82 \%(0,23 \mathrm{~s})$ & $0,54 \%(0,56 s)$ & $0,48 \%(0,24 s)$ \\
\hline YUV & $U-\mathrm{V}$ & 32 & $1,04 \%(0,52 \mathrm{~s})$ & $1,04 \%(0,22 \mathrm{~s})$ & $0,71 \%(0,55 \mathrm{~s})$ & $0,53 \%(0,22 \mathrm{~s})$ \\
\hline$L^{*} a^{*} b^{*}$ & $L^{*} a^{*} b^{*}$ & 32 & $1,07 \%(0,68 s)$ & $1,01 \%(0,32 \mathrm{~s})$ & $0,65 \%(0,70 s)$ & $0,51 \%(0,33 \mathrm{~s})$ \\
\hline
\end{tabular}

De este estudio podemos concluir varios hechos. Primero, que la clasificación por color resulta viable en la práctica al producir unos resultados del 99,5\% de acierto en la clasificación, requiriendo únicamente 0,3 segundos por imagen en un ordenador estándar. Segundo, que los mejores modelos de color son aquellos que separan un canal de luminancia y dos de crominancia, donde los segundos son los que aportan la información relevante para el problema. En concreto, el espacio $\mathrm{L}^{*} \mathrm{a}^{*} \mathrm{~b}^{*}$ ha demostrado estar por encima del resto en la mayoría de los casos; el espacio RGB, a pesar de ser uno de los más extendidos, no debería ser usado para la clasificación automática. Finalmente, la aplicación de operaciones de pre- (reducción de las imágenes con supermuestreo) y postprocesamiento (operadores de morfología matemática) es muy útil para mejorar los resultados y reducir los tiempos de ejecución. Actualmente, el equipo de investigación está trabajando en la implementación de aplicaciones a nivel de usuario para realizar la segmentación automática en dispositivos móviles, usando los resultados de este estudio. 
G Model
AGWAT-3976; No.of Pages9

Agricultural Water Management xxx (2014) xxx-xxx

\section{Study and comparison of color models for automatic image analysis in irrigation management applications}

\section{G. García-Mateos ${ }^{\mathrm{a}, *}$, J.L. Hernández-Hernández ${ }^{\mathrm{c}}$, D. Escarabajal-Henarejos ${ }^{\mathrm{b}}$,}

S. Jaén-Terrones ${ }^{\mathrm{a}}$, J.M. Molina-Martínez ${ }^{\mathrm{b}}$

a Computer Science and Systems Department, University of Murcia, 30100 Murcia, Spain

b Food Engineering and Agricultural Equipment Department, Technical University of Cartagena, Cartagena 30203, Spain

c Academic Unit of Engineering, Autonomous University of Guerrero, Chilpancingo, Guerrero, Mexico

A R T I C L E I N F O

\section{Article history:}

Available online $\mathrm{xxx}$

\section{Keywords:}

Color spaces

Automatic irrigation computation

Image processing in agriculture

Color classification

\begin{abstract}
A B S T R A C T
Image processing and computer vision are increasingly being used in water management applications in agriculture. Images can provide valuable information on the percentage of ground cover, which is essential in determining crop irrigation needs. Techniques based on color analysis allow classifying accurately and efficiently soil/plant regions in the images. Many color spaces have been proposed, among them: RGB, rgb, XYZ, $L^{*} a^{*} b^{*}, L^{*} u^{*} v^{*}, \mathrm{HSV}, \mathrm{HLS}, \mathrm{YCrCb}, \mathrm{YUV}, \mathrm{I} 1 \mathrm{I} 2 \mathrm{I} 3$ and TSL. Different possibilities to model the probability distribution of a given color class appear for each space; one of the most widespread non-parametric methods is modeling using histograms. This presents various alternatives in order to represent a color class: the number of channels, which channels to use, and the size of histograms. Using a wide and varied set of images of lettuce crops (Lactuca sativa)-previously classified manually in soil and plant pixels-a comprehensive analysis and comparison of the proposed color models has been conducted for the soil/plant classification problem. The experimental results demonstrate the superiority of models that separate luminance from chrominance. In particular, $L^{*} a^{*} b^{*}$ provides the best results with $a^{*}$ channel, producing a $99.2 \%$ of correct classification. Further processing stages improve this performance up to $99.5 \%$ accuracy, taking less than $1 / 3$ of a second per image in a normal laptop. These results can be applied to reduce water consumption by optimizing the accuracy and efficiency of automatic image analysis of crops.
\end{abstract}

(c) 2014 Elsevier B.V. All rights reserved.

\section{Introduction}

Automatic analysis of digital images of crops is an interesting and active research field where computer vision and agromotics converge. Color is an essential feature in many problems of this domain, although not all computer vision is based on the use of color; for example, a wide variety of alternative features could be helpful such as edges, shapes, texture, etc. However, color processing has great advantages for its simplicity, robustness, power and efficiency. So far, color has been used in applications related to crop monitoring (Lin et al., 2013), quality control of fruits and vegetables (Kodagali and Balaji, 2012), weed control (Slaughter et al., 2008), and in satellite crop imagery (Campos et al., 2010) among many others.

An important and ubiquitous image processing problem in agriculture is the segmentation of plant pixels from non-plant pixels

\footnotetext{
* Corresponding author. Tel.: +34 8688885 30; fax: +34 868884151 . E-mail address: ginesgm@um.es (G. García-Mateos).

(McCarthy et al., 2010), which is applied in the computation of the percentage of ground cover (PGC) of vegetation. According to Fernández-Pacheco et al. (2014), PGC is defined as "the proportion of land intersected by the vertical projection of vegetation" for a given image; other authors use the terms "top projected leaf area" (Giacomelli et al., 1998) or "vegetation coverage fraction" (Xu et al., 2010). This parameter has a key role in vegetation monitoring and is widely applied to determine crop water requirements using FAO56 methodology (Allen et al., 1998). Moreover, many researchers have found a strong correlation with different parameters that are input for automatic irrigation systems. For example, PGC has been correlated with plant height (Fernández-Pacheco et al., 2014; Grant et al., 2012; Xu et al., 2010), with the crop coefficient Kc (Hanson and May, 2005; López-Urrea et al., 2009; Allen and Pereira, 2009), and with the depth of root in lettuce (Escarabajal-Henarejos et al., 2014), among other parameters.

Automatic estimation of PGC is achieved with specific computer vision systems that can work in indoors or outdoors conditions, from analysis of natural scenes to scenes conditioned by mechanical or optical components used to facilitate the problem (McCarthy 


G Model
$\begin{array}{ll}\text { AGWAT-3976; No.of Pages } 9 & \text { G. García-Mateos et al. / Agricultural Water Management } x x x \text { (2014) } x x x-x x x\end{array}$

et al., 2010). For example, in early works simple thresholding methods were proposed. Giacomelli et al. (1998) estimated PGC of lettuce seedlings using a monochromatic camera; segmentation of plant was manually done with a threshold given by the human operator. Ling and Ruzhitsky (1996) measured PGC in tomato seedlings also from monochromatic images; segmentation was performed with automatic thresholding using Otsu's method. Blasco et al. (2002) developed a robotic system to eliminate weeds in lettuce fields; binary soil/plant classification in the RGB space was done in order to detect weeds in the captured images, reporting $96 \%$ classification accuracy.

More recently, Story et al. (2010) designed a system to detect calcium deficiency in lettuce crops using color and other features; the system works with RGB and HSL color spaces. In Åstrand and Baerveldt (2002), the normalized rgb color space is applied for weed control; they found that the green chromaticity value, $g$, was very effective in distinguishing crop from weed plants, with a $91 \%$ accuracy. Shiraishi and Sumiya (1996) extracted Q chrominance channel from the YIQ space, which is then thresholded to classify pixels as either plant or background. Similarly, Meyer et al. (1998) proposed the method called "excess green index", computed as: $2 \mathrm{G}-\mathrm{R}-\mathrm{B}$, in order to obtain an image where segmentation can be done with a simple threshold. Some authors have extended the concept to the "excess red index", or have mapped the threedimensional RGB color image data into one dimension (Woebbecke et al., 1995). A clustering method was proposed in Steward et al. (2004), in order to define the decision surfaces for the soil/plant classification in the RGB space; success rates range from $89.6 \%$ to $91.9 \%$ for cloudy and sunny lighting conditions, respectively. Some more samples of plant segmentation in agriculture can be found in recent reviews of the state of the art (Lin et al., 2013; McCarthy et al., 2010).

However, despite this extensive literature, there is a significant lack of comparative studies to select the optimum color spaces and color representation techniques for the plant segmentation problem. In most of the works afore mentioned, color processing is performed in a manual, supervised or semi-supervised form. Classification is done by means of thresholding, linear discriminants, Gaussian models, fuzzy logic, neural networks, and others, using a predefined color space; different spaces are not assessed and compared. Those kinds of studies are more common in other domains, particularly in image indexing and retrieval, and human face and skin detection. For example, Shih and Liu (2005) comparatively assessed 12 color spaces in face retrieval applications, and concluded that optimal configurations were obtained with Y-V and Y-I in YUV and YIQ spaces, respectively. Luszczkiewicz-Piatek (2014) focuses on the proper choice of color space for image retrieval in large, heterogenous databases; color is represented using Gaussian mixture models, and 11 color spaces are studied. Terrillon and Akamatsu (2000) introduced the TSL space, and compared 9 color spaces for the problem of human face detection. Human skin color (Kakumanu et al., 2007), and automatic driving systems (Kumar et al., 2002) are other areas where numerous comparative studies of color can be found.

Therefore, the purpose of this work is to perform a complete and thorough analysis of the optimal color spaces and color distribution representations in agriculture. More specifically, the problem of PGC computation in natural, outdoors and unconstrained images is addressed, by automatic binary classification of pixels in soil/plant classes. A total of 11 color spaces are assessed in the experiments, along with all possible combinations of their channels.

The rest of this paper is organized as follows. In Section 2, the set of available images, the color spaces compared, and the methodology for color classification are described in detail. The experimental results are presented and discussed in Section 3, which includes a proposal of some pre- and post-processing techniques to improve the accuracy and efficiency of the method. Finally, Section 4 draws the main conclusions.

\section{Materials and methods}

\subsection{Experimental plot and images used}

The images available for the experiments correspond to lettuce (Lactuca sativa) cultures, located in Cartagena $\left(37^{\circ} 46^{\prime} \mathrm{N}, 0^{\circ} 58^{\prime} \mathrm{W}\right.$ ), Spain, with a commercial planting density $\left(16.5\right.$ plants $\left.\mathrm{m}^{-2}\right)$. Two series of photographs were taken in different seasons. The first series took place between October 2010 and January 2011, and the second one between October and December 2012. In each of both, four small plots were photographed at intervals between 2 and 4 days. The images were taken with a compact digital camera Nikon Coolpix S3300 at high resolution, and present an overhead view of the terrain from a height of about $1.5 \mathrm{~m}$ from the ground, as shown in Fig. 1. The first series contains a total of 108 photographs, and the second series 61. Capture was done in daylight, so illumination conditions were uncontrolled, in some cases receiving direct sunlight and in other cases taken on cloudy days.

Before color analysis, the images were trimmed and normalized with respect to a rectangular pattern that was physically located on the floor; thus, each set corresponds to exactly the same position along time. The normalized images from the first series have a resolution of $1500 \times 1500$ pixel, and $3600 \times 2000$ pixel the second one.

After trimming, the images were manually segmented by experts using the $\mathrm{ENVI}^{\circledR}$ (Environment for Visualizing Images) software (Research System Inc., Boulder, CO, USA) version 4.0. Starting from a manual selection of some regions of interest, this program helps the user to perform a supervised classification of the images. The result is a set of binary images where all pixels are classified either as soil or plant. Some samples are shown in Fig. 2.

In total, there are available 169 high quality images that are very varied in terms of lighting conditions, shadows, percentage of ground cover, soil types, white balance settings, etc. And, more importantly, the soil/plant classification that should ideally produce a perfect automated system is also available as provided by human experts. In the tests described below, the first series of 4 plots is used to train each color model, and the second series of 4 plots is used for the experimental validation of models.

\subsection{Color representation and classification}

The color of a particular pixel can be observed as a stochastic event within the $n$-dimensional space defined by the color space used; there exists a probability distribution for the soil class, and another one for the plant class. In the first case, the color distribution is determined by the type and composition of soil, lighting conditions at the time of taking the picture, soil moisture, and specific camera parameters (for example, the white balance setting). Similarly, the presence of chlorophyll in vegetation implies the predominance of green tones in the plant class, but is also affected by intrinsic and extrinsic factors of the acquisition process.

Suppose that the probability distribution functions of soil color, $p_{\text {soil }}\left(\right.$ color), and plant color, $p_{\text {plant }}($ color), are known, where color is a tuple in some color space; i.e. $p_{\text {soil }}\left(\right.$ color) and $p_{\text {plant }}($ color) represent the probability of observing color if the pixel corresponds to soil or to plant, respectively. For example, in the well-known RGB color space, color is a 3 -valued tuple $(r, g, b)$, with $0 \leq r, g, b \leq 255$.

On the other hand, the a priori probability of soil, $P$ (soil), and plant, $P($ plant $)$, can also be defined. These probabilities are determined by the expected predominance of soil or plant pixels in the images. As shown in Fig. 2, there is not a clear a priori predominance in all images; in some cases, crop cover is less than $4 \%$, while in other 
G Model

AGWAT-3976; No. of Pages 9

\section{ARTICLEE IN PRIESS}

G. García-Mateos et al. / Agricultural Water Management xxx (2014) xxx-xxx

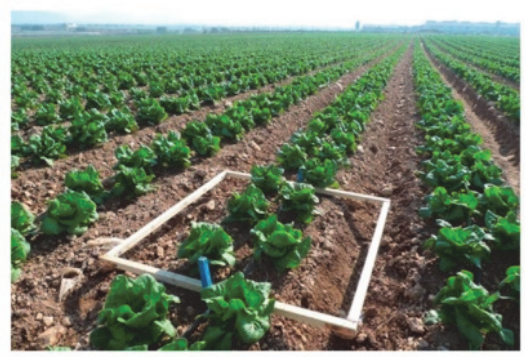

a)

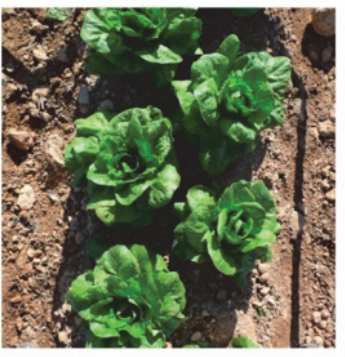

b)

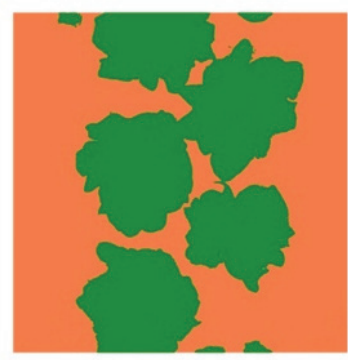

c)

Fig. 1. Overview and sample image from the first series. (a) A top view of the plot with the area of interest marked. (b) A sample photograph of the area of interest. (c) The same photograph after the manual binary plant/soil classification using ENVl ${ }^{\otimes}$.

cases it is above $80 \%$. Accordingly, $P($ soil $)$ and $P$ (plant) are set to 0.5 considering that both classes have the same a priori probability.

Hence, the probability that a certain pixel color belongs to the soil class, or to the plant class, can be easily calculated using the Bayes rule, given by equations:

$$
\begin{aligned}
& P(\text { soil } \mid \text { color })=\frac{p_{\text {soil }}(\text { color }) \times P(\text { soil })}{p_{\text {plant }}(\text { color }) \times P(\text { plant })+p_{\text {soil }}(\text { color }) \times P(\text { soil })} \\
& P(\text { plant } \mid \text { color })=\frac{p_{\text {plant }}(\text { color }) \cdot P(\text { plant })}{p_{\text {plat }}(\text { color }) \cdot P(\text { plant })+p_{\text {soil }}(\text { color }) \cdot P(\text { soil })}
\end{aligned}
$$
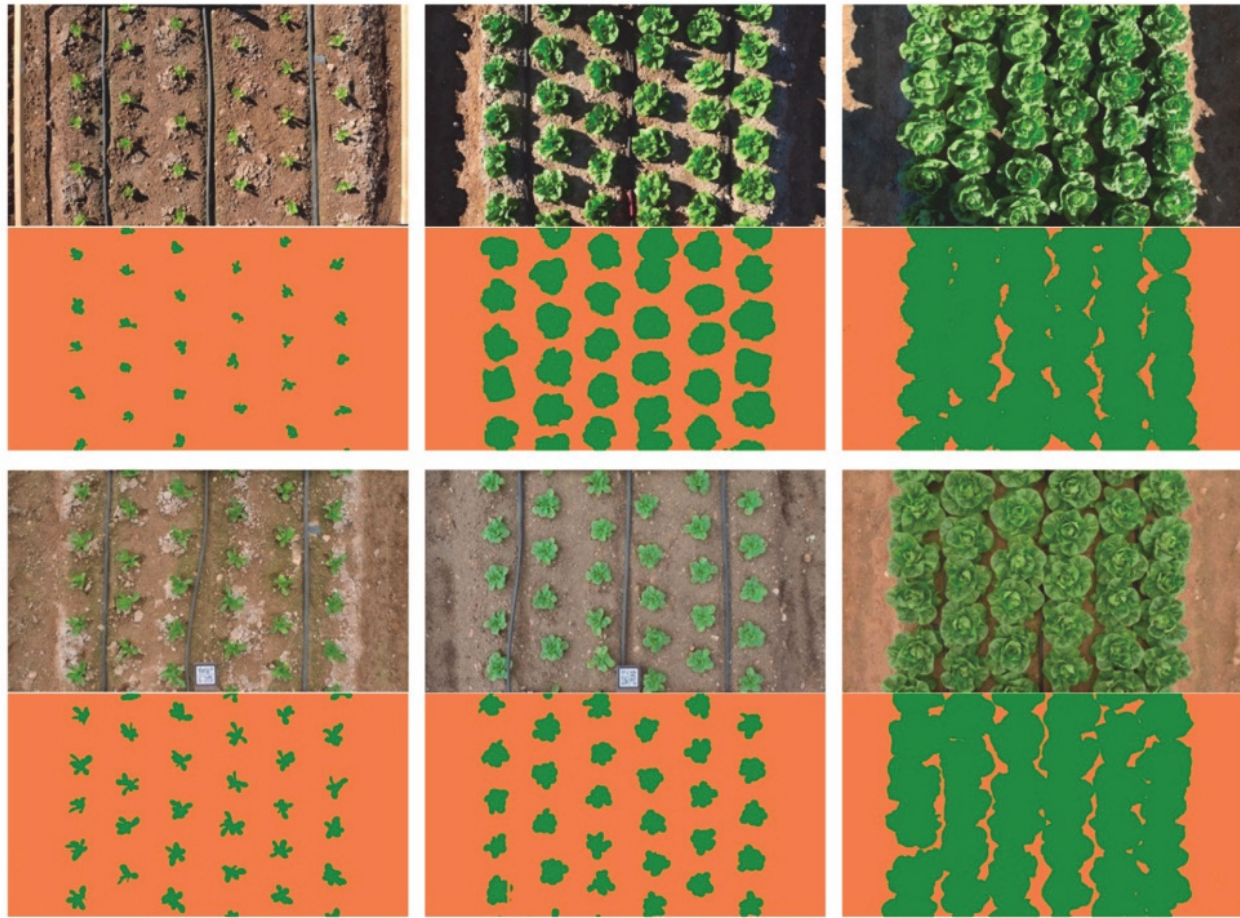

Fig. 2. Some sample images from the second series under different conditions of light, shadows, white balance of the camera, growth state of the plants and other elements (such as a $\mathrm{QR}$ code used to identify the plots). The soil/plant classification given by human experts is shown under each image.

Please cite this article in press as: García-Mateos, G., et al., Study and comparison of color models for automatic image analysis in irrigation management applications. Agric. Water Manage. (2014), http://dx.doi.org/10.1016/j.agwat.2014.08.010 


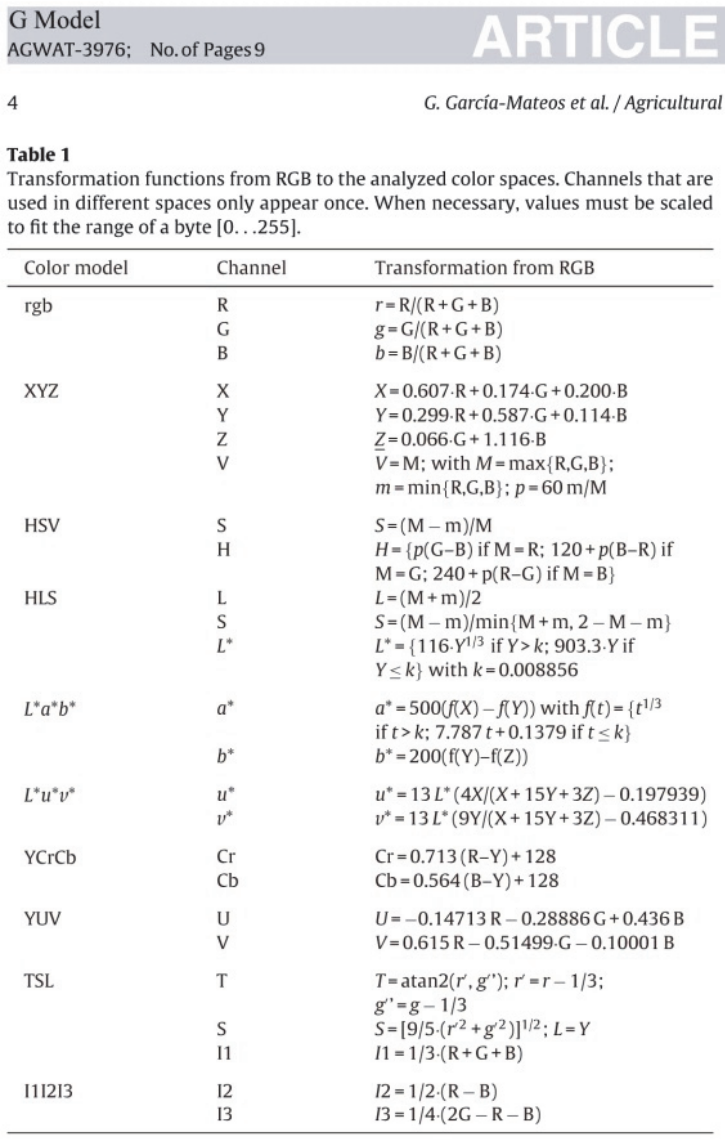

\subsection{Color spaces analyzed}

The spatial shapes adopted by the probability distribution functions, $p_{\text {soil }}\left(\right.$ color) and $p_{\text {plant }}($ color), depend on the color model used. Given a certain color model, the concept of color space can be defined as the $n$-dimensional space induced by all possible tuples of that model. Each dimension of this space is usually called a color channel; all the main color models used in image processing consist of 3 channels, because of the human perception of color.

Each color model defines colors in different terms, thus generating distinct shapes and overlapping degrees between the distributions of the classes under study. The effectiveness of a model is given by two terms: separability, i.e. the ability to separate the distributions of different classes in the color space; and generalization, i.e. the ability to correctly classify samples different from those used during training.

A wide variety of color models have been considered for the experiments, including the most common spaces in computer vision applications (Luszczkiewicz-Piatek, 2014). In general, all these spaces are obtained by transformations of the RGB model, in which images are originally captured. Ten color models have been assessed in addition to RGB: rgb, XYZ, HSV, HLS, $L^{*} a^{*} b, L^{*} u^{*} v^{*}$, $\mathrm{YCrCb}, \mathrm{YUV}, \mathrm{TSL}$ and I1I2I3. Table 1 summarizes the transformation functions from RGB; a sample test image and the resulting channels in these spaces are shown in Fig. 3.

- RGB color model. RGB is the most widespread color space in capture and display devices. It is based on an additive mixture model, where colors are generated by combining three primary colors: red $(R)$, green $(G)$, and blue (B). Henceforth, the values for each channel are considered to be integer values between 0 and 255 ,
i.e. unsigned bytes.

- Normalized rgb color model. An important criticism made to the original RGB color space is that color tuples are sensitive to luminance, surface orientation, and other photographic conditions (Shih and Liu, 2005). In order to minimize such sensitivity, $R, G, B$ can be projected onto the $R=G=B$ plane by dividing the channels by: $(R+G+B)$. This model is called the normalized rgb space.

- CIE XYZ color model. XYZ space, defined by the International Commission on Illumination (CIE) in 1931, is a biologically inspired model, related to the tristimulus color space. Tristimulus describes the response of the three types of photoreceptors in the human retina (or cones), corresponding to: short (S), medium (M) and large (L) wave lengths. Thus, $\mathrm{Z}$ is an approximation of the $\mathrm{S}$ stimulus, $\mathrm{X}$ is a mixture of $\mathrm{L}-\mathrm{M}$, and $\mathrm{Y}$ means luminance.

- Human perceptual HSV and HLS color models. Unlike the previous models, HSV and HLS are described in term of concepts that are easily interpretable by humans, as the hue $(\mathrm{H})$, the saturation or color purity (S), and the brightness $(\mathrm{V}, \mathrm{L})$. Although the definition of $\mathrm{H}$ is the same in both models, $\mathrm{S}$ and brightness are different, as shown in Table 1 . These spaces are very useful and extended in many applications of image analysis and computer graphics.

- Uniform color models $L^{*} a^{*} b^{*}$ and $L^{*} u^{*} v^{*}$. These models were defined by the CIE for industrial applications of color. Channels are defined in order to achieve perceptually uniform color representations, i.e. differences in the spaces are proportional to subjective differences in human perception. Both models consist of a luminance channel $\left(L^{*}\right)$ and two chrominance channels. In $L^{*} a^{*} b^{*}$, channel $a^{*}$ is a green-red axis, and $b^{*}$ is a blue-yellow axis. In $L^{*} u^{*} v^{*}, u^{*}$ and $v^{*}$ are defined as non-linear transformations of $X$ and $Y$, respectively.

- Luminance/chrominance models YCrCb and YUV. YCrCb, YUV and YIQ spaces are very common in image compression and communication; for example, $\mathrm{YCrCb}$ is internally used in JPEG and MPEG standards. They consist on separating a luminance channel Y (which is the same as in CIE XYZ), and two chrominance channels that are independent of the color brightness. $\mathrm{Cr}$ and $\mathrm{Cb}$ essentially correspond to $\mathrm{R}$ and $\mathrm{B}$ channels normalized in intensity, respectively. YUV and YIQ are also given by linear transformations of RGB. I-Q plane is a $33^{\circ}$ rotation of $U-V$ plane; therefore, only YUV is used in the experiments.

- Application specific models I1I2I3 and TSL. Some color models have been defined for particular domains of applications. For example, TSL was introduced in Terrillon and Akamatsu (2000) for human face and skin detection. T means tint and is a predominant-color channel similar to $\mathrm{H}$ in HSV/HLS, including white in the scale; $\mathrm{S}$ is a saturation channel; and $\mathrm{L}$ is luminance defined as Y in CIE XYZ. On the other hand, I1I2I3 was proposed in Ohta et al. (1980) for color segmentation, as a decorrelation of RGB components using the Karhunen-Loeve transform.

\subsection{Representation of color probability distribution functions}

Modeling probability distribution functions from a set of observations is a basic problem in pattern recognition and, in general, in artificial intelligence. Given a class of interest, whose samples lie in an $n$-dimensional space, the objective is to estimate the probability of observing each point in the space for that particular class. The observations used to estimate the probability density functions are also known as training samples, in contrast to the observations used to validate the model, known as test samples. In our case, the target functions are $p_{\text {soil }}\left(\right.$ color) and $p_{\text {plant }}($ color), where color is a 1,2 or 3-dimensional tuple. 
G Model

AGWAT-3976; No. of Pages 9 ARTICLEIN PRESS

G. García-Mateos et al. / Agricultural Water Management xxx (2014) xxx-xxx

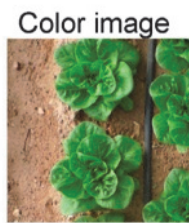

$r$

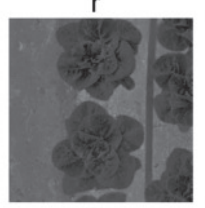

$\mathrm{H}$

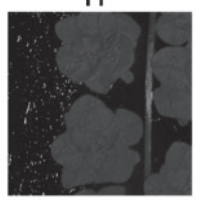

$\mathrm{L}^{*}$

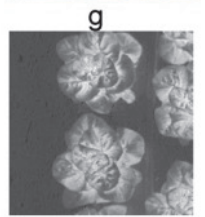

$\mathrm{S}$
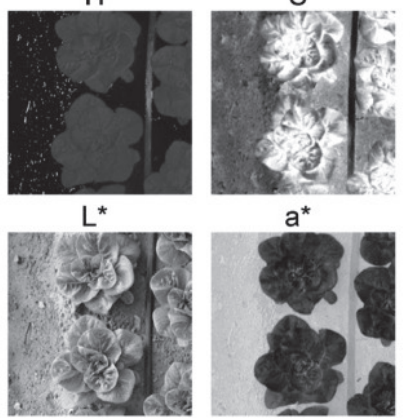

Y

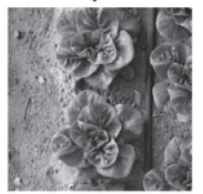

I1

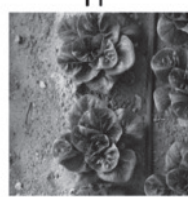

$a^{\star}$

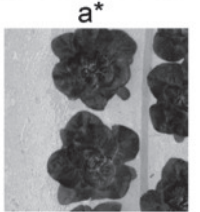

$\mathrm{Cr}$

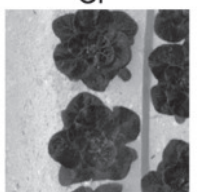

12

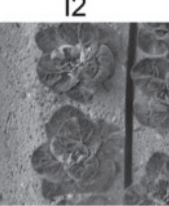

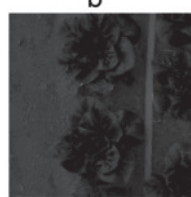

V

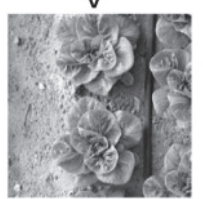

$b^{*}$

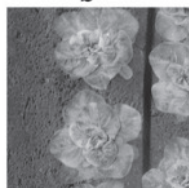

$\mathrm{Cb}$

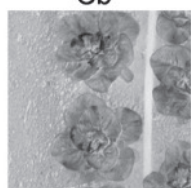

13

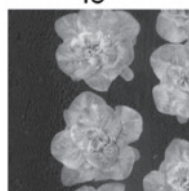

$\mathrm{R}$

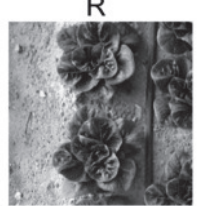

$\mathrm{X}$

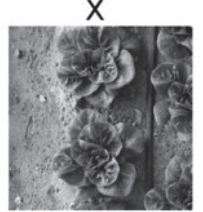

$\mathrm{H}$

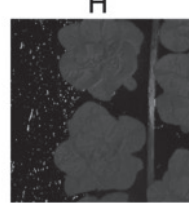

$L^{*}$

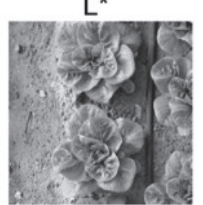

$Y$

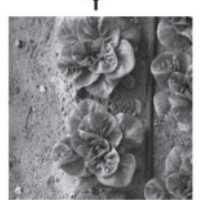

$\mathrm{T}$

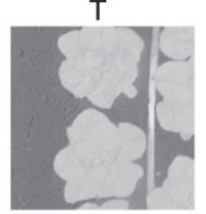

G

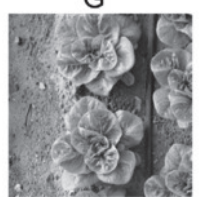

$Y$

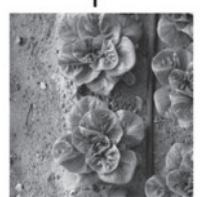

L

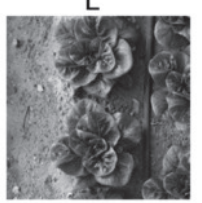

$u^{*}$

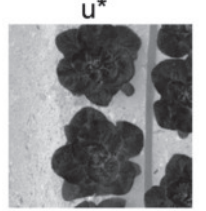

U

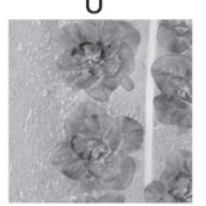

$\mathrm{S}$

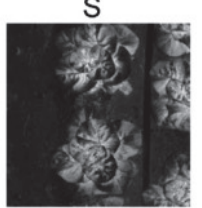

B

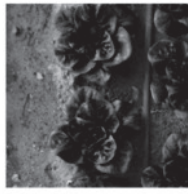

Z

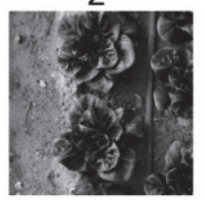

$\mathrm{S}$

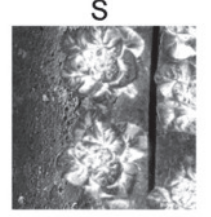

$v^{\star}$

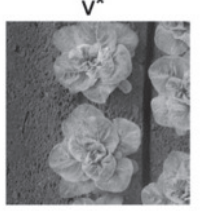

V

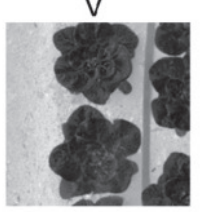

L

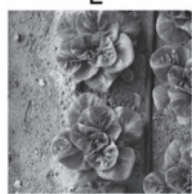

Fig. 3. Channels of the 11 color spaces used in a sample crop image. From left to right, top to bottom, the color spaces are: RGB, rgb, XYZ, HSV, HLS, $L^{*} a^{*} b^{*}, L^{*} u^{*} v^{*}$, YCrCb, YUV, I11213 and TSL.

Different methods have been proposed in order to obtain good approximations of density functions. The so-called parametric methods assume that functions have an analytic form which is a priori known, e.g. Gaussians or mixtures of Gaussians (Luszczkiewicz-Piatek, 2014). On the other hand, when the form of data is unknown - or when the distribution has a very complex shape - non-parametric methods are preferred. Among them, those based on histograms are the most common when working in low-dimensional spaces with a large number of samples available (Kakumanu et al., 2007). This method consists of calculating the histogram of the observed data, which is then normalized to sum 1. Each bin in the histogram is considered as an approximation of the probability in the range of the corresponding bin.

The computation of histograms involves a discretization of the input space. Let $f($ color) define a discretization function that maps each color to a given range. The histogram for a particular class, $H_{\text {class }}$, is calculated as the set of frequencies of $f($ color) for all the training samples of that class. Then, the estimation of the probability density function is given by:

$p_{\text {class }}($ color $)=\frac{H_{\text {class }}(f(\text { color }))}{N_{\text {class }}}$

where $N_{\text {class }}$ is the number of training samples available for that class.

Two decisions have to be taken when defining function $f$ :

- The number of channels to be used. Not all channels are useful for the problem, so dropping some of them may produce better results than using all. This selection determines the dimensionality of the histogram: 1, 2 or 3. Let consider, for example, the RGB color space. Then, seven configurations appear, that consist on using the channels: R, G, B, R-G, R-B, G-B and R-G-B; similarly for all the rest of spaces. 
G Mode AGWAT-3976; No. of Pages9

\section{$A R T I C L=I N$ PRESS}

G. García-Mateos et al. / Agricultural Water Management xxx (2014) xxx-xxx

- The range of the discretized space, i.e. the size of the histograms in each dimension. This discretization is usually done by powers of 2 , thus producing an equal distribution of the input range (histogram bins are always supposed to be uniformly spaced).

The optimum selection of these parameters is intimately related to the number of training samples available. This problem is also known in pattern recognition as the curse of dimensionality: the smaller the number of training samples, the smaller the number of usable bins in the histogram, and, hence, the smaller the number of dimensions in the color model and bins in each dimension.

Summing up, for each of the 11 color spaces, the options are: using one channel, two-channels or three channels histograms ( 7 combinations); and using $16,32,64,128$ or 256 bins per dimension. Accordingly, 385 different ways of representing color are analyzed and compared.

\section{Results and discussion}

For each alternative - given by the triplet: color space, channels to use, and histogram size - soil and plant color distributions are trained using the images from the first series, with a total of 108 images containing $65.25 \times 10^{6}$ pixels of the plant class, and $206.48 \times 10^{6}$ of the soil class. Afterwards, the overlap between the probability distributions of both classes is measured. It is calculated as the integral of the minimum area of the two histograms in that model:

$\operatorname{overlap}($ model $)=\sum_{i \in \text { Bins }(\text { model })} \min \left\{p_{\text {soil }}(i), p_{\text {plant }}(i)\right\}$

Then, automatic classification of images in the second series is performed. This series includes 61 high resolution images with $167.4 \times 10^{6}$ and $295.1 \times 10^{6}$ pixels of plant and soil, respectively. The obtained results are compared with the manual classification given by the human experts. Classification accuracy is given by the number of test pixels correctly classified divided by the total number of test pixels. Finally, some techniques to further improve classification results, based on image decimation and morphology operators, are studied. The final classification accuracy is obtained as the similarity between the percentage of ground cover computed by the system and that provided by the ground-truth.

\subsection{Overlap between distributions and classification accuracy}

As described in the previous section, overlap accounts for the separability of each alternative, while classification accuracy assesses generalizability. Both terms are closely related, but a good separability does not necessarily yield a model that generalizes well. Table 2 shows the main results regarding overlap values. Due to the high amount of data, only the results for 256 bins are shown, corresponding in all cases to the minimum overlaps. Fig. 4 contains some sample histograms of both classes for different color spaces and configurations. On the other hand, the results of automatic classification on the second series of images are shown in Table 3, which contains the percentage of correctly classified pixels.

Examining the channels individually, the best results both in overlap and classification accuracy are clearly achieved by $a^{*}$ in $L^{*} a^{*} b^{*}$ with a $0.95 \%$ overlap and $99.2 \%$ accuracy. This is an expected outcome, given that $a^{*}$ represents a green-red axis that maximized the separation between plant and soil colors. Significantly, the best accuracy is obtained for a histogram size of 32 bins. Moreover, for 64,128 and 256 bins it always remains above $98.7 \%$, so the election of size is not critical in this case. This result is also related to the number of training samples available, as mentioned above. However, although the average number of samples per bin is above
$10^{6}$ in the case of 256 bins, smaller sizes usually produce the best results.

Within a significant difference, the following best options are channels $\mathrm{I} 3$ in I1I2I3, $\mathrm{Cr}$ in $\mathrm{YCrCb}, \mathrm{V}$ in $\mathrm{YUV}, u^{*}$ in $L^{*} u^{*} v^{*}, \mathrm{H}$ in $\mathrm{HSV} / \mathrm{HLS}$, and T in TSL, with overlaps always below $2.1 \%$ and classification accuracies above $96 \%$. In all cases, channels related to pixe brightness (as Y in XYZ/YCrCb/YUV, V in HSV, and $L^{*}$ in $L^{*} a^{*} b^{*} / L^{*} u^{*} v$ ) produce considerable overlap and very poor accuracy. As a consequence, none of the RGB or XYZ channels is able by itself to achieve a good result, since they are affected by luminance.

Considering two channels combinations, it is remarkable that removing brightness channels yields better results in most cases, as in $L^{*} a^{*} b^{*}, L^{*} u^{*} v^{*}, \mathrm{YCrCb}$, YUV and I1I2I3. This is consistent with the fact that luminance is mainly related to the lighting conditions of the image, and not the content of the scene. Nevertheless, some combinations as $L^{*}-a^{*}$ and $\mathrm{X}-\mathrm{Y}$ are exceptions to this rule. The second case is especially interesting, going from $53 \%$ accuracy for individual channels, to $98.94 \%$ for the $X-Y$ pair. The histogram of $X-Y$ can be observed in Fig. 4, which explains the separability gained by the combination of both channels.

Finally, when three channels are used, overlaps are always reduced and accuracies are above $96 \%$ in all studied spaces. However, not all models generalize equally well. In fact, in 6 of the 11 color spaces, it is preferable to use only 1 or 2 channels. Also, the best results are achieved with only 16 or 32 bins; with sizes 128 and 256 , the errors increase up to a $5.2 \%$. These facts prove that a small dimensionality is required to avoid overfitting to the training data, which could produce a falsely good overlap measure, but very poor classification accuracy.

On the other hand, since all spaces are given by transformations of RGB, the global minimum overlap corresponds to R-G-B histograms using 256 bins per channels. The resulting $0.31 \%$ overlap means that the same RGB tuple is sometimes classified as soil and other times as plant. This can be due to two causes: an error in the manual classification given by the experts; or a genuine overlap in the color distributions, e.g. in shadowed or in saturated areas of the images.

\subsection{Discussion and further improvements}

The best color modeling configurations are able to produce classification errors near or below $1 \%$; that is, $99 \%$ of the pixels are correctly classified as soil/plant. As shown in Fig. 5, classification errors can be of two kinds: false positives (soil pixels classified as plant), and false negatives (plant pixels classified as soil). One of the main sources of error is over- or under-saturation of certain image parts when capture was done with excessive or deficient illumination, respectively; some pixels appear very near to white or black, so color information is almost lost. This is prone to produce most of the false negatives. On the other hand, in images where the percentage of ground cover is very high, ambient light is severely affected by reflections in the vegetation; consequently, soil under the plants can adopt a green tone, producing false positives.

Further processing stages can be added to the process in order to reduce the error of the computed PGC measure (which is the ultimate output of the process):

- Preprocessing: image decimation with supersampling interpolation. As the original images are obtained in high resolution, a reduction by 2 or 4 in the size does not affect the definition of objects of interest in the scene, so accuracy of the PGC measure is maintained. Decimation is done by supersampling, which is equivalent to averaging the pixels by 4 or 16 , respectively. The effect is a reduction in pixel noise and the removal of spurious pixels (e.g. over/under saturated individual pixels). 
G Model

AGWAT-3976; No. of Pages 9

\section{ARTICLEE IN PRESS}

G. García-Mateos et al. / Agricultural Water Management xxx (2014) xxx- xxx

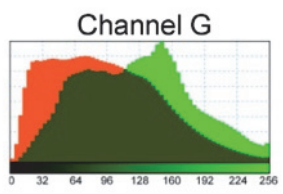

Channels $X-Y$

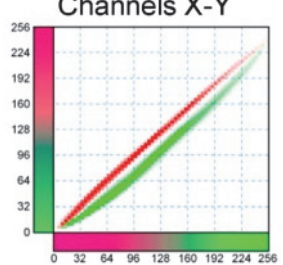

Channels R-G-B

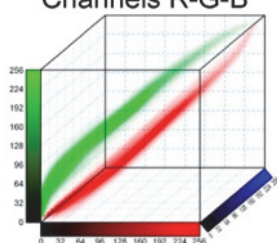

Channel g

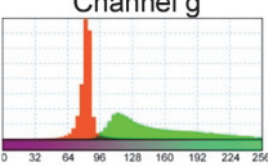

Channels $\mathrm{Cr}-\mathrm{Cb}$

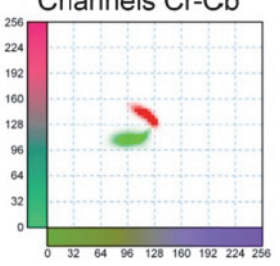

Channels H-L-S

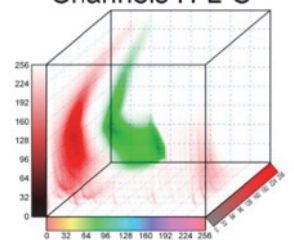

Channel a*

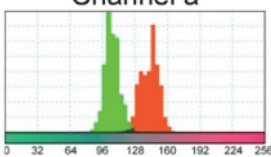

Channels I1-13

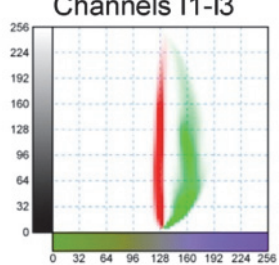

Channels $L^{*}-a^{*}-b^{*}$

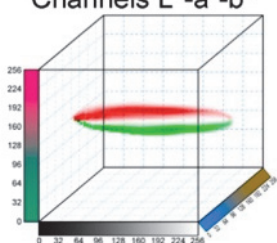

Channel $\mathrm{H}$

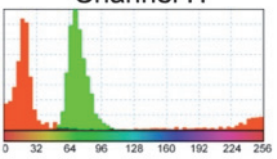

Channels T-L

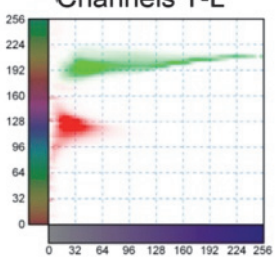

Channels Y-U-V

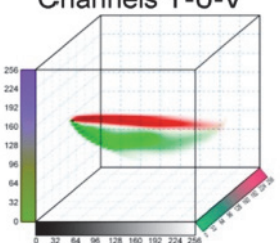

Fig. 4. Probability distributions of soil (in red) and plant (in green) classes, for different color spaces and channels using the first series of images. Histogram size is always 64 bins per channel. (For interpretation of the references to color in this figure legend, the reader is referred to the web version of this article.)

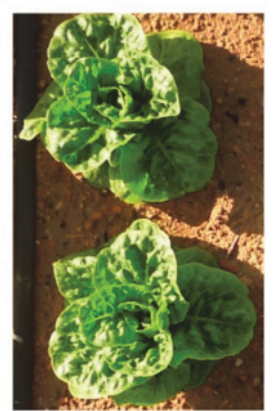

a) $483 \times 775$ pixe/s

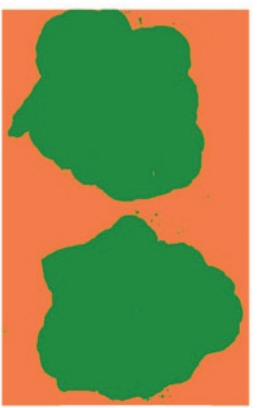

b)

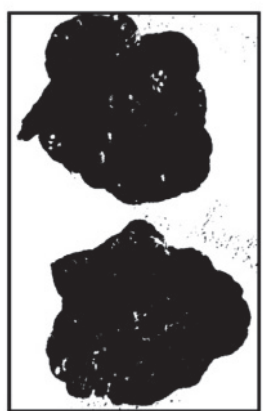

c1) $1.89 \%$ error

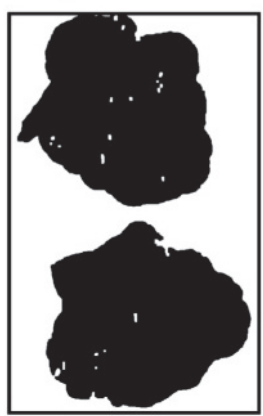

c2) $1.79 \%$ error

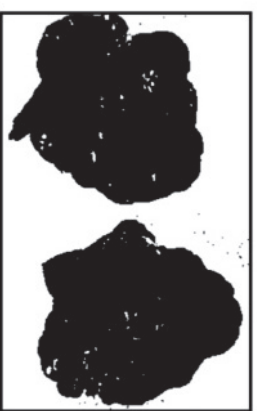

d1) $1.62 \%$ error

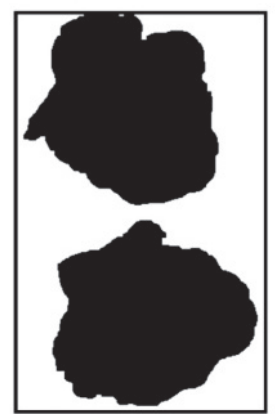

d2) $1.29 \%$ error

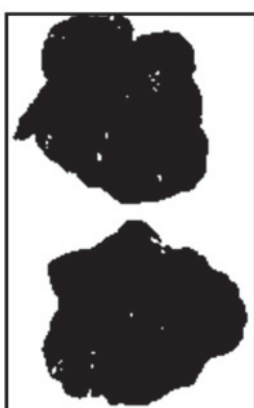

e1) $1.37 \%$ error

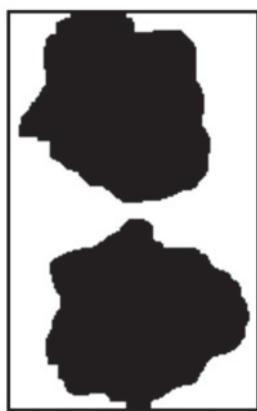

e2) $1.34 \%$ error

Fig. 5. Automatic soil/plant classification using channel $a^{*}$ in $L^{*} a^{*} b^{*}$ with 32 bins. (a) Fragment from a test image. (b) Manual classification used as ground-truth. (c)-(e) Classification results with: (c1) and (c2) original size; (d1) and (d2) size decimated by 2; (e1) and (e2) size decimated by 4. (c2), (d2) and (e2) Corresponding results after application of morphology operators.

Please cite this article in press as: García-Mateos, G., et al., Study and comparison of color models for automatic image analysis in irrigation management applications. Agric. Water Manage. (2014), http://dx.doi.org/10.1016/j.agwat.2014.08.010 


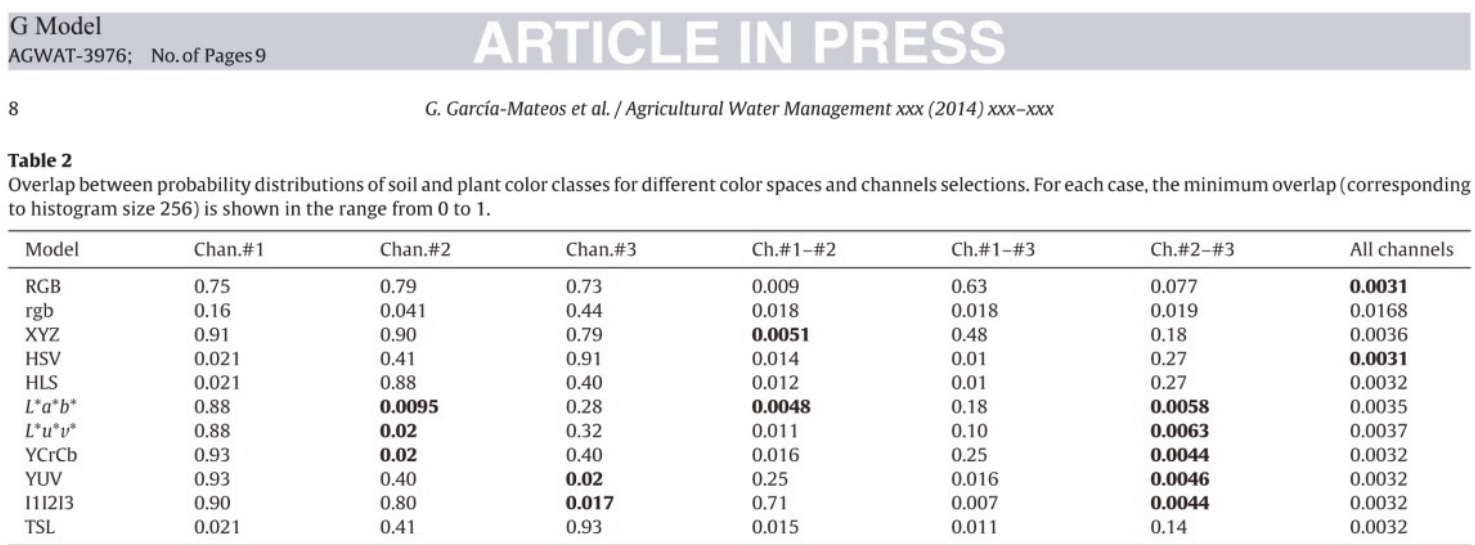

Table 3

Accuracy rates of automatic soil/plant classification for different color spaces and channels selections in \%. For each case, the histogram size that yields the best result is shown in brackets.

\begin{tabular}{llllllll}
\hline Space & Chan. \#1 & Chan. \#2 & Chan. \#3 & Ch.\#1-\#2 & Ch. \#1-\#3 & Ch. \#2-\#3 & All channels \\
\hline RGB & $60.57(16)$ & $60.09(128)$ & $70.11(16)$ & $98.22(64)$ & $69.05(16)$ & $93.52(128)$ & $98.48(32)$ \\
rgb & $80.71(32)$ & $96.05(16)$ & $80.52(32)$ & $96.34(256)$ & $96.26(256)$ & $96.50(16)$ \\
XYZ & $53.37(16)$ & $50.90(16)$ & $66.84(32)$ & $\mathbf{9 8 . 9 4 ( 1 2 8 )}$ & $76.45(128)$ & $88.39(64)$ & $96.54(256)$ \\
HSV & $96.18(256)$ & $80.68(16)$ & $49.56(32)$ & $96.84(16)$ & $97.88(256)$ & $82.73(32)$ & $\mathbf{9 8 . 8 6 ( 3 2 )}$ \\
HS & $96.18(256)$ & $56.20(16)$ & $79.88(16)$ & $97.23(256)$ & $97.83(256)$ & $82.72(64)$ & $\mathbf{9 8 . 8 6 ( 3 2 )}$ \\
$L^{*} a^{*} b^{*}$ & $52.11(64)$ & $\mathbf{9 9 . 2 0 ( 3 2 )}$ & $85.72(32)$ & $\mathbf{9 9 . 0 8 ( 6 4 )}$ & $88.28(256)$ & $\mathbf{9 9 . 0 0 ( 3 2 )}$ \\
$L^{*} u^{*} v^{*}$ & $51.85(16)$ & $97.61(128)$ & $84.89(32)$ & $97.86(256)$ & $92.44(256)$ & $\mathbf{9 8 . 7 3 ( 1 6 )}$ \\
YCrCb & $50.75(16)$ & $96.06(256)$ & $82.31(32)$ & $96.52(128)$ & $85.54(64)$ & $\mathbf{9 8 . 8 2 ( 6 4 )}$ & $98.59(64)$ \\
YUV & $50.75(16)$ & $81.00(128)$ & $96.05(64)$ & $85.35(128)$ & $96.51(128)$ & $\mathbf{9 8 . 9 3 ( 3 2 )}$ \\
I112I3 & $57.22(256)$ & $53.57(16)$ & $\mathbf{9 8 . 7 1 ( 2 5 6 )}$ & $57.20(256)$ & $\mathbf{9 8 . 8 6 ( 1 2 8 )}$ & $\mathbf{9 8 . 8 5 ( 3 2 )}$ & $98.49(64)$ \\
TSL & $96.29(256)$ & $81.03(16)$ & $48.87(16)$ & $96.59(256)$ & $97.69(256)$ & $\mathbf{9 8 . 6 7}(\mathbf{3 2})$ \\
\hline
\end{tabular}

Table 4

Error rates and execution times of automatic classification for the seven best color spaces and channels, and different improvements; average errors are shown in \% (in brackets, average execution times in seconds). Original: original resolution images; Decim. 2: size decimated by 2; Decim. 4: size decimated by 4; Morph. 1: morphology operators applied with original size; Morph. 2: morphology and decimated by 2; Morph. 4: morphology and decimated by 4.

\begin{tabular}{lllllllll}
\hline Space & Channels & Bins & Original & Decim.2 & Decim.4 & Morph.1 & Morph.2 & Morph.4 \\
\hline$L^{*} a^{*} b^{*}$ & $a^{*}$ & 32 & $0.84 \%(0.53 \mathrm{~s})$ & $0.80 \%(0.29 \mathrm{~s})$ & $0.72 \%(0.23 \mathrm{~s})$ & $0.65 \%(0.56 \mathrm{~s})$ & $0.55 \%(0.30 \mathrm{~s})$ & $0.59 \%(0.24 \mathrm{~s})$ \\
$L^{*} a^{*} b^{*}$ & $L^{*}-a^{*}$ & 64 & $0.78 \%(0.58 \mathrm{~s})$ & $0.75 \%(0.30 \mathrm{~s})$ & $0.69 \%(0.23 \mathrm{~s})$ & $0.53 \%(0.61 \mathrm{~s})$ & $0.51 \%(0.31 \mathrm{~s})$ & $0.69 \%(0.24 \mathrm{~s})$ \\
$\mathrm{T} b^{*}$ & $\mathrm{~T}-\mathrm{S}-\mathrm{L}$ & 16 & $0.87 \%(1.54 \mathrm{~s})$ & $0.77 \%(1.28 \mathrm{~s})$ & $0.69 \%(1.22 \mathrm{~s})$ & $0.57 \%(1.45 \mathrm{~s})$ & $0.60 \%(1.29 \mathrm{~s})$ & $0.92 \%(1.22 \mathrm{~s})$ \\
$L^{*} a^{*} b^{*}$ & $a^{*}-b^{*}$ & 32 & $0.99 \%(0.55 \mathrm{~s})$ & $0.94 \%(0.28 \mathrm{~s})$ & $0.82 \%(0.21 \mathrm{~s})$ & $0.67 \%(0.58 \mathrm{~s})$ & $0.54 \%(0.29 \mathrm{~s})$ & $0.63 \%(0.22 \mathrm{~s})$ \\
XYZ & $\mathrm{X}-\mathrm{Y}$ & 128 & $0.87 \%(0.53 \mathrm{~s})$ & $0.82 \%(0.23 \mathrm{~s})$ & $0.72 \%(0.15 \mathrm{~s})$ & $0.54 \%(0.56 \mathrm{~s})$ & $0.48 \%(0.24 \mathrm{~s})$ & $0.94 \%(0.15 \mathrm{~s})$ \\
YUV & $\mathrm{U}-\mathrm{V}$ & 32 & $1.04 \%(0.52 \mathrm{~s})$ & $1.04 \%(0.22 \mathrm{~s})$ & $0.87 \%(0.14 \mathrm{~s})$ & $0.71 \%(0.55 \mathrm{~s})$ & $0.53 \%(0.22 \mathrm{~s})$ & $0.55 \%(0.15 \mathrm{~s})$ \\
$L^{*} a^{*} b^{*}$ & $L^{*}-a^{*}-b^{*}$ & 32 & $1.07 \%(0.68 \mathrm{~s})$ & $1.01 \%(0.32 \mathrm{~s})$ & $0.85 \%(0.24 \mathrm{~s})$ & $0.65 \%(0.70 \mathrm{~s})$ & $0.51 \%(0.33 \mathrm{~s})$ & $0.67 \%(0.24 \mathrm{~s})$ \\
\hline
\end{tabular}

- Postprocessing: open and close morphological operators. When applied on binary images, close operator has the effect of removing small black areas inside a white region (false negatives), whilst open operator removes white areas inside black regions (false positives). The combination of both operators, with an adequate number of iterations, allows reducing the total error.

The application of these improvements is shown in Table 4, which contains the average errors between the manually computed PGC and those given by automatic classification, for the best color configurations in the previous subsection. In these tests, morphology operators were applied after decimation (where indicated), with 2 iterations of open and close in all cases. The average execution times of the whole classification process for each $3600 \times 2000$ pixels image are also shown (the computer used is an off-the-shelf laptop with an Intel ${ }^{\circledR}$ i5 CPU at $2.27 \mathrm{GHz}$ and 4 Gbytes of RAM; the implementation was done in $\mathrm{C}++$ with QtCreator 2.7.2 using OpenCV 2.4.6 computer vision libraries).

All the proposed methods are able reduce the original error, ranging from a mean $5 \%$ of error reduction with decimation by 2 , to a $40 \%$ reduction combining decimation by 2 and morphology operators. Not only the accuracy is significantly improved, but also the execution times are reduced up to a $40 \%$, as the images are smaller after decimation. The optimal election is $\mathrm{X}-\mathrm{Y}$ in $\mathrm{XYZ}$, with a $0.48 \%$ of error in the PGC computation (very close to the theoretical optimum of $0.31 \%$ ) and requiring only $0.24 \mathrm{~s}$ per image.

In general, these results are consistent with the conclusions obtained by other authors in different domains. For example, in Luszczkiewicz-Piatek (2014) the optimal spaces for image retrieval are found to be $L^{*} a^{*} b^{*}$ among the non-linear transformations of RGB, and I1I2I3 among the linear ones; the latter is argued to be preferred since it can be computed more efficiently. In Shih and Liu (2005), the authors found that for the problem of face retrieval chromaticity configurations outperform intensity channels, with YUV and YIQ among the best spaces. Similarly, YCrCb is shown to be the optimal space in (Kumar et al., 2002), but $L^{*} a^{*} b^{*}$ was not included in the experiments.

\section{Conclusions}

A precise estimation of irrigation needs in agriculture depends on many factors, among which the percentage of ground cover is

Please cite this article in press as: García-Mateos, G., et al., Study and comparison of color models for automatic image analysis in irrigation management applications. Agric. Water Manage. (2014), http://dx.doi.org/10.1016/j.agwat.2014.08.010 


G Model
AGWAT-3976; No.of Pages9

a key parameter. Digital image processing can be effectively used to obtain this parameter by means of color analysis. The choice of the optimal color space, as well as how to represent the probability distributions of color, is an essential prerequisite in any application that makes use of color. Through a wide and comprehensively series of experiments, 385 different combinations of color spaces, channels and histogram sizes have been explored for the problem of automatic soil/plant classification in water management applications.

Three main conclusions can be drawn from the experimental results. First, color is by itself a very powerful feature to solve the problem of PGC estimation. Color features allow an efficient and accurate classification that is performed pixel by pixel. The performance obtained is very close to the theoretical optimal result, given by the manual classification error; and it can be greatly improved with morphology and decimation operations, achieving $99.5 \% \mathrm{accu}-$ racy in the best case.

Second, the best color spaces are those that separate luminance from chrominance, where the latter provides most relevant information. Among them, channels representing a red-green axis are preferred for the studied problem. In particular, channel $a^{*}$ in $L^{*} a^{*} b$ is found to be the optimal election, with an accuracy of $99.2 \%$ by itself.

And third, in order to avoid the risk of overfitting to the training data, the dimensionality of the representation must be kept small. This refers both to the number of channels and histogram bins that are used to represent color distributions. In most cases, the optimum is obtained with 32 and 64 bins per dimension.

The results of this study can be used to develop more accurate and efficient systems to compute in real time the irrigation requirements of crops, through a precise and fast estimation of the PGC. Moreover, the proposed methodology could be applied in other problems that rely on plant segmentation, as weed control, detection of diseases, and crop monitoring in general.

Future research lines include the application of dimensionality reduction techniques, as the well-known Linear Dimensionality Analysis (LDA), that would produce a 1D or 2D projection of RGB data that optimally separates lettuce and soil classes. This could improve classification results and avoid the dependency on the color space used. On the other hand, although this paper focuse on color analysis, more advanced techniques could be used for regularizing the obtained binary images instead of mathematical morphology, as for example graph-cuts-based techniques. This could solve many errors in situations when color is not enough by itself to discriminate the existing classes.

\section{Acknowledgements}

This work was supported by the Spanish MINECO unde grant TIN2012-38341-C04-03, and by the "Seneca Foundation" (Murcia Regional Authority, Spain) through the project with ref. 08729/PI/08

\section{References}

Allen, R.G., Pereira, L.S., Raes, D., Smith, M., 1998. Crop EvapotranspirationGuidelines for Computing Crop Water Requirements-FAO Irrigation and Drainage Paper 56. FAO, Rome, pp. 6541
Allen, R.G., Pereira, L.S., 2009. Estimating crop coefficients from fraction of ground cover and height. Irrig. Sci. 28, 17-34.

Astrand, B., Baerveldt, A.J. 2002. An agricultural mobile robot with vision-based perception for mechanical weed control. Autonomous Robots 13, 21-35.

Blasco, J.. Aleixos, N., Roger. J.M., Rabatel, G., Molto, E., 2002. Robotic weed control using machine vision. Biosyst. Eng. 83 (2), 149-157.

Campos, I., Neale, C.M., Calera, A., Balbontín, C., González-Piqueras, J., 2010. Assessing satellite-based basal crop coefficients for irrigated grapes (Vitis vinifer Water Manage. 98, 45-54.

Escarabajal-Henarejos. D. Molina-Martínez, J.M. Fernández-Pacheco, D.G. GarcíaMateos, G. 2014. Methodology for obtaining prediction models of D.G., Garcíalettuce for its application in irrigation automation. Agric. Water Manage (this

Fernández-Pacheco, D.G., Escarabajal, D., Ruiz-Canales, A., Conesa, J., MolinaMartinez, J.M., 2014. A digital image-processing-based method for determining the crop

Giacomelli, G.A., Ling.P.P., Kole,J., 1998. Determining nutrient stress in lettuce plants with machine vision technology. HortTechnology 8 (3), 361-365.

Grant, O.M., Davies, M.J., Longbottom, H., Harrison-Murray, R., 2012. Evapotranspiration of container ornamental shrubs: modelling crop-specific factors for diverse range of crops. Irrigation Science 30 (1), 1-12.

Hanson, B.R., May, D.M., 2005. Crop coefficients for drip-irrigated processing tomato. Agric. Water Manage. 81 (3), 381-399.

Kakumanu, P., Makrogiannis, S., Bourbakis, N., 2007. A survey of skin-color modeling and detection methods. Pattern Recognit.V 40 (3), 1106-1122.

Kodagali, J.A., Balaji, S., 2012. Computer vision and image analysis based techniques for automatic characterization of fruits-a review. Int. J. Comput. Appl. 50 (6), $6-12$.

Kumar, P., Sengupta, K., Lee, A., 2002. A comparative study of different color spaces for foreground and shadow detection for traffic monitoring system. The IEEE 5 th International Conference on Intelligent Transportation Systems, 100-105.

Lin, K., Chen, J., Si, H., Junhui, W., 2013. A review on computer vision technologies applied in greenhouse plant stress detection. Adv. Image Graphics Technol. 363 $192-200$

Ling. P.P., Ruzhitsky, V.N., 1996. Machine vision techniques for measuring the canopy of tomato seedling. J. Agric. Eng. Res. 65, 85-95.

López-Urrea, R., Martín de Santa Olalla, F., Montoro, A., López-Fuster, P., 2009. Single and dual crop coefficients and water requirements for onion (Allium cepa L. under semiarid conditions. Agric. Water Manage. 96, 1031-1036.

Luszczkiewicz-Piatek, M., 2014. Which color space should be chosen for robust color image retrieval based on mixture modeling. Adv. Intell. Syst. Comput. 233, $55-64$

McCarthy, C.L., Cheryl, N.H., Hancock, S.R., 2010. Applied machine vision of plants-a review with implications for field deployment in automated farming operations. (

Meyer, G.E., Mehta, T., Kocher, M.F., Mortensen, D., Samal, A.A., 1998. Textural imaging and discriminant analysis for distinguishing weeds for spot spraying. Trans.

Ohta, Y., Kanade, T., Sakai, T., 1980. Color information for region segmentation. Comput. Graphics Image Process. 13 (3), 222-241.

Shih, P., Liu, C., 2005. Comparative assessment of content-based face image retrieval in different color spaces. Int. J. Patt. Recogn. Artif. Intell. 19 (7), $873-$

Shiraishi, M. Sumiya, H. 1996. Plant identification from leaves using quasi-senso fusion. J. Manuf. Sci. Eng, Trans, ASME 118 (3), 382-387.

Slaughter. D. . Giles. D.K. Downey. D. 2008 . Autonomous robotic weed control systems: a review. Comput. Electron. Agric. 61, 63-78.

Steward, B.L. Tian, LF. Nettleton, D. Tang . L, 2004. Reduced-dimension clusterin for vegetation segmentation. Trans. ASAE 47 (2), 609-616.

Story, D., Kacira, M., Kubota, C., Akoglu, A., An, L.L., 2010. Lettuce calcium deficiency detection with machine vision computed plant features in controlled ciency detection with machine vision computed plant

Terrillon, J.C., Akamatsu, S., 2000. Comparative performance of different chrominance spaces for color segmentation and detection of human faces in complex scene images. In: International Conf. on Face and Gesture Recognition, pp. 54-61.

Xu, X.G., Wang.J.H., Li, C.J., Song, X.U., Huang, W.J., 2010. Estimating growth height of winter wheat with remote sensing. In: In Proceedings of the SPIE 7824, Remote Sensing for Agriculture, Ecosystems, and Hydrology XII.

Woebbecke, D.M., Meyer, G.E., Von Bargen, K., Mortensen, D.A., 1995. Color indices for weed identification under various soil, residue, and lighting conditions. Trans. ASAE 38 (1), 259-269, 



\section{Conclusiones Generales}

Los trabajos desarrollados durante la elaboración de esta Tesis Doctoral han permitido obtener las siguientes conclusiones generales:

a) La determinación de coeficientes de cultivo $K c$ mediante el método de Bowen, requiere realizar una calibración previa del equipo sobre el cultivo de referencia, para determinar con exactitud dichos coeficientes en los cultivares de lechuga ensayados, adaptados a las condiciones climáticas y técnicas de manejo del cultivo específicas de la zona de estudio. El método de Bowen mostró una subestimación generalizada de las medidas lisimétricas de $E T$, debido a la presencia del fenómeno de advección detectado de naturaleza regional.

b) El empleo de RTDs para estimar la ET mediante aplicación del balance de energía a la superficie del cultivo, mostró un mejor ajuste a las medidas lisimétricas de $E T$ frente al empleo de los convencionales TMPs instalados en los equipos Bowen. Así pues, se sugiere la sustitución de TMPs por RTDs; además los RTDs son sensores más eficaces y de bajo coste, que presentan una mayor simplicidad de instalación, así como un menor coste de mantenimiento a largo plazo, mostrándose como un instrumento más robusto que apenas requiere mantenimiento.

c) La fracción de cobertura vegetal $(P G C)$ es un parámetro de desarrollo del cultivo de sencilla y rápida determinación mediante la aplicación de fotografía digital y técnicas de procesamiento de imágenes. Se trata de una variable que además puede ser relacionada, de forma matemática, con otros parámetros como la profundidad 
radicular del cultivo $(z)$, de gran importancia para establecer el balance hídrico del suelo; la altura de la planta $(h)$, o el coeficiente de cultivo $K c$. Este último parámetro interviene en el proceso de determinación de las necesidades hídricas del cultivo mediante la metodología FAO-56.

d) La aplicación de la fotografía digital y las técnicas de procesamiento de imágenes a nivel de parcela, permitió desarrollar y validar una nueva metodología operativa para estimar el coeficiente de cultivo $K c$ de cultivos de lechuga sobre la base de fotografías digitales de la cubierta vegetal. La relación de los parámetros $P G C, h$ y $K c$ permitió obtener ecuaciones matemáticas con las que modelar satisfactoriamente dichas relaciones, demostrando la validez del método.

e) La aplicación de esta nueva metodología a la estimación de las necesidades hídricas de cultivos de lechuga 'Little Gem', permitió obtener mejores rendimientos económicos del cultivo asociados a una mayor productividad y menor consumo de agua de riego.

f) La profundidad radicular del cultivo es un parámetro de gran importancia a considerar en el establecimiento del balance hídrico de cualquier cultivo. Conocer su evolución durante el ciclo de desarrollo del cultivo es de vital importancia para conseguir establecer un balance hídrico ajustado únicamente a la zona efectiva de absorción radicular, cuestión que frecuentemente es ignorada, recurriéndose al empleo de valores fijos tabulados o propuestos por la bibliografía.

g) La excelente relación observada entre $z$ y $P G C$ en los cultivares de lechuga ensayados, permitió desarrollar una metodología operativa y no destructiva, para obtener modelos predictivos de la profundidad radicular del cultivo basados en la obtención del parámetro $P G C$ a partir del procesamiento informático de fotografías digitales de la cubierta vegetal. Durante los dos ciclos de cultivo estudiados, primavera y otoño, se logró correlacionar satisfactoriamente $z$ y $P G C$, demostrando la validez de la metodología.

h) El procesamiento de imágenes y la visión artificial resultan cada vez más útiles y necesarios en diversas aplicaciones agromóticas de gestión de cultivos. Los estudios para seleccionar el espacio de color óptimo y la forma más efectiva de representar las distribuciones de color en el proceso de segmentación automática de imágenes digitales de cubiertas vegetales para la obtención del parámetro $P G C$, 
permite mejorar las metodologías desarrolladas y validadas en los experimentos llevados a cabo.

i) El color es por sí mismo una característica muy potente para resolver el problema de la estimación de $P G C$. Las características de color permiten una clasificación eficiente y precisa realizada píxel a píxel. El rendimiento obtenido está muy próximo del resultado óptimo teórico, dado por el error de clasificación manual; y se puede mejorar en gran medida con las operaciones de morfología y de diezmado, consiguiendo una precisión del 99,5\% en el mejor de los casos.

j) Los mejores espacios de color son aquellos que separan la luminancia de la crominancia, donde éste último proporciona información más relevante. En concreto, el canal a* en el modelo $L * a * b *$ demostró estar por encima del resto en la mayoría de los casos, con una precisión del 99,2\% por sí mismo. El espacio RGB, a pesar de ser uno de los más extendidos, no debería ser usado para la clasificación automática.

k) La aplicación de operaciones de pre- (reducción de las imágenes con supermuestreo) y post-procesamiento (operadores de morfología matemática) es muy útil para mejorar los resultados y reducir los tiempos de ejecución. Actualmente, el equipo de investigación está trabajando en la implementación de aplicaciones a nivel de usuario para realizar la segmentación automática en dispositivos móviles, usando los resultados de este estudio.

Considerando que el desarrollo de metodologías basadas en fotografía digital tiene un carácter preliminar y novedoso en el ámbito de la programación y gestión del riego, se proponen las siguientes líneas de investigación:

a) Extrapolar los resultados obtenidos a otros cultivares de lechuga $u$ otros cultivos hortícolas, extendiendo la validación de las metodologías desarrolladas en esta Tesis Doctoral a diferentes condiciones climáticas, técnicas de manejo del cultivo, sistemas de riego, etc.

b) Aplicar las técnicas de fotografía digital y procesamiento de imágenes al control del estado fisiológico de los cultivos mediante la obtención de diversos parámetros de la planta (temperatura foliar, medidas dendrométricas, entre otros) y obtención de nuevos indicadores de control del riego. 
c) Diseñar un equipo agromótico basado en técnicas de fotogrametría que integre las metodologías y algoritmos desarrollados en la presente Tesis Doctoral, e implantarlo en un sistema automático de programación del riego a tiempo real que permita gestionar el riego de la parcela a partir del monitoreo del crecimiento del cultivo mediante visión computarizada. 


\section{Referencias}

Aboukhaled, A., Alfaro, A., Smith, M., 1982. Lysimeters. In: FAO Irrigation and Drainage Paper No. 39. FAO, Rome, Italy (p. 68).

Adamsen, F., Coffelt, T., Nelson, J.M., Barnes, E.M., Rice, R.C., 2000. Method for using images from a color digital camera to estimate flower number. Crop Sci. 40, 704 709.

Ahamed, T., Tian, L., Jiang, Y.S., Zhao, B., Liu, H., Ting, K.C., 2012. Tower remotesensing system for monitoring energy crops; image acquisition and geometric corrections. Biosyst. Eng. 112 (2), 93-107.

Ahmadi, S.H., Fooladmand, H.R., 2008. Spatially distributed monthly reference evapotranspiration derived from the calibration of Thornthwaite equation: a case study, South of Iran. Irrig. Sci. 26 (4), 303-312.

Al-Ghobari, H.M., 2000. Estimation of reference evapotranspiration for southern region of Saudi Arabia. Irrig. Sci. 19 (2), 81-86.

Allen, R.G., Jensen, M.E., Wright, J.L., Burman, R.D., 1989. Operational estimates of reference evapotranspiration. Agron. J. 81, 650-662.

Allen, R.G., Pereira, L.S., Raes, D., Smith, M., 1998. Crop evapotranspiration: guidelines for computing crop water requirements. In: FAO Irrigation and Drainage Papers. FAO, Rome, Italy, p. 328. 
Allen, R.G., Wright, J.L., Pruitt, W.O., Pereira, L.S., 2007. Water requirements. In: Hoffman, G.J., Evans, R.G., Jensen, M.E., Martin, D.L., Elliot, R.L. (Eds.), Design and Operation of Farm Irrigation Systems, ASABE, Monograph. ASABE, St. Joseph, MI, pp. 208-288.

Allen, R.G., Pereira, L.S., 2009. Estimating crop coefficients from fraction of ground cover and height. Irrig. Sci. 28 (1), 17-34.

Allen, R.G., Pereira, L.S., Howell, T.A., Jensen, M.E., 2011a. Evapotranspiration information reporting. I: Factors governing measurement accuracy. Agric. Water Manage. 98, 899-920.

Allen, R.G., Pereira, L.S., Howell, T.A., Jensen, M.E., 2011b. Evapotranspiration information reporting. II: Recommended documentation. Agric. Water Manage. 98, 921-929.

Andreas, E.L., Jordan, R.E., Mahrt, L., Vickers, D., 2013. Estimating the Bowen ratio over the open and ice-covered ocean. J. Geophys. Res. Oceans 118, 4334-4345.

Aydin, M., 2008. A model for evaporation and drainage investigations at ground of ordinary rainfed-areas. Ecol. Model. 217 (1-2), 148-156.

Ayers, R.S., Westcot, D.W., 1987. La calidad del agua en la agricultura. Folleto FAO Riego y Drenaje No. 29. Food and Agriculture Organization of the United Nations, Rome.

Baillie, I.C., 2001. Soil survey staff 1999, soil taxonomy. Soil Use Manage. 17 (1), 5760.

Balbontín-Nesvara, C., Calera-Belmonte, A., Gonzalez-Piqueras, J., Campos-Rodriguez, I., Lopez-Gonzalez, M.L., Torres-Prieto, E., 2011. Vineyard evapotranspiration measurements in a semiarid environment: Eddy covariance and Bowen ratio comparison. Agrociencia 45 (1), 87-103.

Bert Jr., J., Honma, S., 1975. Effect of soil moisture and irrigation method on tipburn and edgeburn severity in greenhouse lettuce. J. Am. Soc. Hortic. Sci. 100 (3), 278-282.

Bezerra, B.G., da Silva, B.B., Bezerra, J.R.C., Sofiatti, V., dos Santos, C.A.C., 2012. Evapotranspiration and crop coefficient for sprinkler-irrigated cotton crop in Apodi Plateau semiarid lands of Brazil. Agric. Water Manage. 107, 86-93. 
Blackmer, T.M., J.S. Schepers, G.E. Varvel, G.E. Meyer, 1996. Analysis of aerial photography for nitrogen stress within corn fields. Agron. J. 88, 729-733.

Blasco, J., Aleixos, N., Roger, J., Rabatel, G., Molto, E., 2002. AE-Automation and Emerging Technologies: robotic weed control using machine vision. Biosyst. Eng. 83, 149-157.

Boote, K.J., Jones, J.W., Hoogenboom, G., White, J.W., 2010. The role of crop systems simulation in agriculture and environment. Int. J. Agric. Environ. Inf. Syst. 1, 4154.

Bowen, I.S., 1926. The ratio of heat losses by conduction and by evaporation from any water surface. Phys. Rev. 27 (6), 779-787.

Boyd, N.S., Gordon, R., Martin, R.C., 2002. Relationship between leaf area index and ground cover in potato under different management conditions. Potato Res. 45 (23), 117-129.

Brown, P., Doley, D., Keenan, R., 2000. Estimating tree crown dimensions using digital analysis of vertical photographs. Agric. For. Meteorol. 100, 199-212.

Calera, A., Martínez, C., Meliá, J., 2001. A procedure for obtaining green plant cover: relation to NDVI in a case study for barley. Int. J. Remote Sens. 22, 3357-3362.

Campbell Scientific, 1998. Bowen Ratio Instrumentation, Instruction Manual. Campbell Scientific, Logan, UT, p. 23.

Campillo, C., Garcia, M.I., Daza, C., Prieto, M.H., 2010. Study of a non-destructive method for estimating the leaf area index in vegetable crops using digital images. Hort. Sci. 45 (10), 1459-1463.

Cancela, J.J., Cuesta, T.S., Neira, X.X., Pereira, L.S., 2006. Modelling for improved irrigation water management in a temperate region of Northern Spain. Biosyst. Eng. $94(1), 151-163$.

Cayrol, P., Chehbouni, A., Kergoat, L., Dedieu, G., Mordelet, P., Nouvellon, Y., 2000. Grassland modeling and monitoring with SPOT-4 VEGETATION instrument during the 1997-1999 SALSA experiment. Agric. For. Meteorol. 105, 91-115. 
Congling, W., Guanghui, T., Changying, L., 2005. Application and validation of computer vision based nondestructive measurement system for cucumber seedling growth conditions. Trans. Chin. Soc. Agric. Eng. 21 (4), 109-112.

Córcoles, J., Ortega, J., Hernández, D., Moreno, M., 2013. Use of digital photography from unmanned aerial vehicles for estimation of leaf area index in onion (Allium cepa L.). Eur. J. Agron. 45, 96-104.

Costa, J.M., Ortuño, M.F., Chaves, M.M., 2007. Deficit irrigation as a strategy to save water: physiology and potential application to horticulture. J. Integr. Plant Biol. 49 (10), 1421-1434.

Cubero, S., Aleixos, N., Moltó, E., Gómez-Sanchis, J., Blasco. J., 2011. Advances in machine vision applications for automatic inspection and quality evaluation of fruits and vegetables. Food Bioprocess Tech. 4 (4), 487-504.

Cui, Y.J., Zornberg, J.G., 2008. Water balance and evapotranspiration monitoring in geotechnical and geoenvironmental engineering. Geotech. Geol. Eng. 26 (6), 783798.

De Bruin, H.A.R., 2008. Theory and application of large aperture scintillometers. In: Short Course Notes. Scintec Corp.

De Medeiros, G.A., Arruda, F.B., Sakai, E.L., Fujiwara, M., 2001. The influence of crop canopy on evapotranspiration and crop coefficient of beans (Phaseolus vulgaris L.). Agric. Water Manage. 49, 211-224.

DehghaniSanij, H., Yamamoto, T., Rasiah, V., 2004. Assessment of evapotranspiration estimation models for use in semi-arid environments. Agric. Water Manage. 64 (2), 91-106.

Dicken, U., Cohen, S., Tanny, J., 2013. Examination of the Bowen ratio energy balance technique for evapotranspiration estimates in screenhouses. Biosyst. Eng. 114, 397405.

Domínguez, A., Tarjuelo, J., de Juan, J., López-Mata, E., Breidy, J., Karam, F., 2011. Deficit irrigation under water stress and salinity conditions: the MOPECO-salt model. Agric. Water Manage. 98, 1451-1461.

Doorenbos, J., Pruitt, W.O., 1977. Crop water requirements. In: FAO Irrigation and Drainage Paper No. 24. FAO, Rome. 
Dunin, F.X., Barrs, H.D., Meyer, W.S., Trevitt, A.C.F., 1991. Foliage temperature and latent heat flux of irrigated wheat. Agric. For. Meteorol. 55 (1-2), 133-147.

Eilers, V.H.M., Carter, R.C., Rushton, K.R., 2007. A single layer soil water balance model for estimating deep drainage (potential recharge): an application to cropped land in semi-arid North-east Nigeria. Geoderma 140 (1), 119-131.

Elsawwaf, M., Willems, P., Pagano, A., Berlamont, J., 2010. Evaporation estimates from Nasser Lake, Egypt, based on three floating station data and Bowen ratio energy budget. Theor. Appl. Climatol. 100, 439-465.

Escarabajal-Henarejos, D., Molina-Martínez, J.M., Fernández-Pacheco, D.G., GarcíaMateos, G., 2014. Methodology for obtaining prediction models of root depth of lettuce for its application in irrigation automation. Agric. Water Manage. In press.

Ewing, R.P., Horton, R., 1999. Quantitative color image analysis of agronomic images. Agron. J. 91, 148-153.

Fandiño, M., Cancela, J.J., Rey, B.J., Martínez, E.M., Rosa, R.G., Pereira, L.S., 2012. Using the dual-Kc approach to model evapotranspiration of Albariño vineyards (Vitis vinifera L. cv. Albariño) with consideration of active ground cover. Agric. Water Manage. $112(0), 75-87$.

Fernández García, F., 1995. Manual de climatología aplicada: Clima, medio ambiente y planificación. Síntesis, Madrid.

Fernández-Pacheco, D.G., Escarabajal-Henarejos, D., Ruiz-Canales, A., Conesa, J., Molina-Martínez, J.M., 2014. A digital image-processing-based method for determining the crop coefficient of lettuce crops in the southeast of Spain. Biosyst. Eng. 117, 23-34.

Figuerola, P.I., Berliner, P.R., 2005. Evapotranspiration under advective conditions. Int. J. Biometeorol. 49, 403-416.

Fortin, J.G., Parent, L.E., Anctil, F., Bolinder, M.A., 2008. Neural network to simulate potato tuber yield in Eastern Canada. Acta Hort. 802, 309-318.

Fritschen, L., Simpson, J., 1982. An automatic system for measuring Bowen ratio gradients using platinum resistance elements. In: Schooley, J.F. (Ed.), Temperature, Its Measurement and Control in Science and Industry, 5. Am. Institute of Physics, New York, NY, pp. 739-742. 
Gavilan, P., Berengena, J., 2007. Accuracy of the Bowen ratio-energy balance methodfor measuring latent heat flux in a semiarid advective environment. Irrig. Sci. 25 (2), $127-140$.

Giacomelli, G.A., Ling, P.P., Morden, R.E., 1996. An automated plant monitoring system using machine vision. Acta Hort. 440, 377-382.

Giacomelli, G.A., Ling, P.P., Kole, J., 1998. Determining nutrient stress in lettuce plants with machine vision technology. Hort Tech. 8 (3), 361-365.

Gocic, M., Trajkovic, S., 2010. Software for estimating reference evapotranspiration using limited weather data. Comput. Electron. Agric. 71 (2), 158-162.

Gocic, M., Trajkovic, S., 2011. Service-oriented approach for modeling and estimating reference evapotranspiration. Comput. Electron. Agric. 79 (2), 153-158.

Goncalves, J.M., Muga, A.P., Horst, M.G., Pereira, L.S., 2011. Furrow irrigation design with multicriteria analysis. Biosyst. Eng. 109 (4), 266-275.

Grant, O.M., Davies, M.J., Longbottom, H., Harrison-Murray, R., 2012. Evapotranspiration of container ornamental shrubs: modelling crop-specific factors for a diverse range of crops. Irrig. Sci. 30 (1), 1-12.

Grattan, S.R., Bowers, W., Dong, A., Snyder, R.L., Carroll, J.J., George, W., 1998. New crop coefficients estimate water use of vegetables, row crops. Calif. Agr. 52 (1), $16-21$.

Griffin, T.S., Johnson, B.S., Ritchie, J.T., 1993. A simulation model for potato growth and development: Substor-potato Version 2.0. Department of Agronomy and Soil Science, College of Tropical Agriculture and Human Resources, University of Hawaii, Honolulu, Hawaii, USA.

Haboudane, D., Miller, J.R., Pattey, E., Zarco-Tejada, P.J., Strachan, I.B., 2004. Hyperspectral vegetation indices and novel algorithms for predicting green LAI of crop canopies: modeling and validation in the context of precision agriculture. Remote Sens. Environ. 90, 337-352.

Hanson, B.R., May, D.M., 2006. Crop coefficients for drip-irrigated processing tomato. Agric. Water Manage. 81, 381-399. 
Harrold, L.L., Watts, C.J., Rodriguez, J.C., De Bruin, H.A.R., 1966. Measuring evapotranspiration by lysimetry. In: Proceeding Conference on Evapotranspiration. Am. Soc. Agr. Engrs, Chicago, IL, USA, pp. 28-33.

Hartogensis, O.K., Watts, C.J., Rodriguez, J.C., De Bruin, H.A.R., 2003. Derivation of an effective height for scintillometers: La Poza experiment in Northwest Mexico. J. Hydrometeorol. 4 (5), 915-928.

Heilman, J.L., Brittin, C.L., Neale, C.M.U., 1989. Fetch requirements for Bowen-ratio measurements of latent and sensible heat fluxes. Agric. For. Meteorol. 44 (3-4), $261-273$.

Howell, T.A., McCormick, R.L., Phene, C.J., 1985. Design and installation of large weighing lysimeters. Trans. ASAE 28 (1), 106-112.

Hsiao, T.C., Heng, L., Steduto, P., Rojas-Lara, B., Raes, D., Fereres, E., 2009. AquaCropthe FAO crop model to simulate yield response to water. III: Parameterization and testing for maize. Agron. J. 101, 448-459.

Itier, B., 1996. Measurement and estimation of evapotranspiration. In: Pereira, L.S., Feddes, R.A., Gilley, J.R., Lesaffre, B. (Eds.), Sustainability of Irrigated Agriculture. Kluwer Academic Publishers, Holanda.

ASCE, 1974. Consumptive use of water and irrigation water requirements. In: Jensen, M.E. (Ed.), Rep. Tech. Com. on Irrig. Water Requirements, Irrig. and Drain. Div., ASCE, p. 227.

Jensen, M.E., Burman, R.D., Allen, R.G., 1990. Evapotranspiration and Irrigation Water Requirements, ASCE-Manuals and Reports on Engineering Practice, No. 70. ASCE, New York, NY.

Jiyane, J., Zermeño-González, A., 2003. Applying the equilibrium evapotranspiration approach to irrigated agriculture in arid zones. Agrociencia 37 (6), 553-563.

Kenney, W., 1987. A method for estimating windbreak porosity using digitized photographic silhouettes. Agric. For. Meteorol. 39, 91-94.

Kirk, K., Andersen, H.J., Thomsen, A.G., Jorgensen, J.R., Jorgensen, R.N., 2009. Estimation of leaf area index in cereal crops using red-green images. Biosyst. Eng. 104 (3), 308-317. 
Kirkham, R.R., Rockhold, M.L., Gee, G.W., Fayer, M.J., Campbell, M.D., Fritschen, L.J., 1991. Lysimeters. Data acquisition and analysis. In: Proc. of the International Symposium on Lysimeters for Evapotranspiration and Environmental Measurements, ASCE, Honolulu, HI, USA, pp. 362-370.

Laliberte, A., Rango, A., Herrick, J., Fredrickson, E.L., Burkett, L., 2007. An objectbased image analysis approach for determining fractional cover of senescent and green vegetation with digital plot photography. J. Arid. Environ. 69, 1-14.

Lecina, S., Martínez-Cob, A., 2000. Evaluación lisimétrica de la evapotranspiración de referencia semihoraria calculada con el método FAO Penman-Monteith. In: XVIII Congreso Nacional de Riegos, Huelva, Spain, pp. 37-38.

Lecina, S., Martínez-Cob, A., Pérez, P.J., Villalobos, F.J., Baselga, J.J., 2003. Fixed versus variable bulk canopy resistance for reference evapotranspiration estimation using the Penman-Monteith equation under semiarid conditions. Agric. Water Manage. 60 (3), 181-198.

Lee, X., Yu, Q., Sun, X., Liu, J., Min, Q., Liu, Y., Zhang, X., 2004. Micrometeorological fluxes under the influence of regional and local advection: a revisit. Agric. For. Meteorol. 122 (1-2), 111-124.

Leite, M.L., Sediyama, G.C., Coelho, D.T., Vieira, H.A., 1990. Determinação da evapotranspiração de equilibrio numa superficie cultivada com Feijoão (Phaseolus vulgaris L.) em duas densidades de plantío. Ceres 37, 99-110.

Lin, K., Chen, J., Si, H., Junhui, W., 2013. A review on computer vision technologies applied in greenhouse plant stress detection. Adv. Image Graphics Technol. 363, 192-200.

Ling, P.P., Ruzhitsky, V.N., 1992. Transplant uniformity inspection using machine vision. Acta Hort. 319, 607-612.

López-Urrea, R., Martín de Santa Olalla, F., Fabeiro, C., Moratalla, A., 2006a. Testing evapotranspiration equations using lysimeter observations in a semiarid climate. Agric. Water Manage. 85 (1-2), 15-26.

López-Urrea, R., Montoro, A., López-Fuster, P., 2006b. Estudio de las necesidades hídricas de la cebada (Hordeum vulgare L.) cultivada en un clima semiárido. In: XXIV Congreso Nacional de Riegos, Lugo, Spain. 
López-Urrea, R., Martín de Santa Olalla, F., Montoro, A., López-Fuster, P., 2009a. Single and dual crop coefficients and water requirements for onion (Allium cepa L.) under semiarid conditions. Agric. Water Manage. 96 (6), 1031-1036.

López-Urrea, R., Montoro, A., López-Fuster, P., Fereres, E., 2009b. Evapotranspiration and responses to irrigation of broccoli. Agric. Water Manage. 96 (7), 1155-1161.

Lorente, D., Aleixos, N., Gómez-Sanchis, J., Cubero, S., García-Navarrete, O.L., Blasco, J., 2012. Recent advances and applications of hyperspectral imaging for fruit and vegetable quality assessment. Food Bioprocess Technol. 5, 1121-1142.

Lu, H.Y., Lu, C.T., Wei, M.L., Chan, L.F., 2004. Comparison of different models for nondestructive leaf area estimation in taro. Agron. J. 96 (2), 448-453.

Luszczkiewicz-Piatek, M., 2014. Which color space should be chosen for robust color image retrieval based on mixture modeling. Adv. Intell. Syst. Comput. 233, 55-64.

Ma, Y., Feng, S., Song, X., 2013. A root zone model for estimating soil water balance and crop yield responses to deficit irrigation in the North China Plain. Agric. Water Manage. 127, 13-24.

Mackerron, D.K.L., 2007. Mathematical models of plant growth and development. In: Vreugdenhil, D., Bradshaw, J., Gebhardt, C., Govers, F., Mckerron, D.K.L., Taylor, M.A., Ross, H.A. (Eds.), Potato Biology and Biotechnology Advances and Perspectives. Elsevier, Amsterdam, Netherlands, pp. 753-776.

Maidment, D.R. (Ed.), 1992. Handbook of Hydrology. McGraw-Hill, Austin, Texas.

Makkink, G.P., 1957. Testing the Penman formula by means of lysimeters. J. Inst.Water Eng. 11, 277-288.

Marek, T.H., Schmeider, A.D., Howell, T.A., Ebeling, L.L., 1988. Design and construction of large weighing monolithic lysimeters. Trans. ASAE 31 (2), 477484.

Martin de Santa Olalla, F.J., de Juan, J.A., 1993. Capítulo: La programación de riegos. In: Agronomía del Riego. Mundi-Prensa, Madrid, pp. 549-610.

McCarthy, C.L., Cheryl, N.H., Hancock, S.R., 2010. Applied machine vision of plants-a review with implications for field deployment in automated farming operations. Intell. Serv. Rob. 3 (4), 209-217. 
Meir, P., Grace, J., Miranda, A.C., 2000. Photographic method to measure the vertical distribution of leaf area density in forests. Agric. For. Meteorol. 102, 105-111.

Meyers, T.P., Baldocchi, D.P., 2005. Current micrometerological flux methodologies with applications in agriculture. In: Hatfield, J.L., Baker, J.M. (Eds.), Micrometeorology in Agricultural Systems. Agronomy Monograph No. 47 in the Agro Series. American Society of Agronomy, Crop Science Society of America, Soil Science Society of America, Madison, WI, USA, pp. 381-396.

Mize, J.H., Cox, J.G., 1968. Essentials of Simulation. Prentice Hall, Englewood Cliffs, N.J.

Molina-Martínez, J.M., Jiménez, M., Ruiz-Canales, A., Fernández-Pacheco, D.G., 2011. RaGPS: a software application for determining extraterrestrial radiation in mobile devices with GPS. Comput. Electron. Agric. 78 (1), 116-121.

Monsi, M., Saeki, T., 1953. Uber den lichtfaktor inden pflanzen gesselschaften und seine bedeutung fur di estoff produktion. Jpn. J. Bot. 14, 22-52.

Napier, D.R., Combrink, N.J.J., 2006. Aspects of calcium nutrition to limit plant physiological disorders. Acta Hort. (ISHS) 702, 107-116.

Nishat, S., Guo, Y., Baetz, B.W., 2007. Development of a simplified continuous simulation model for investigating long-term soil moisture fluctuations. Agric. Water Manage. 92 (1), 53-63.

Ohmura, A., 1982. Objective criteria for rejecting data for Bowen ratio flux calculations. J. Appl. Meteorol. 21 (4), 595-598.

Ohta, Y., Kanade, T., Sakai, T., 1980. Color information for region segmentation. Comput. Graphics Image Process. 13 (3), 222-241.

Oron, G., DeMalach, Y., Gillerman, L., David, I., Lurie, S., 2002. Effect of water salinity and irrigation technology on yield and quality of pears. Biosyst. Eng. 81 (2), 237247.

Ortega-Farias, S.O., Cuenca, R.H., Ek, M., 1996. Daytime variation of sensible heat flux estimated by the bulk aerodynamic method over a grass canopy. Agric. For. Meteorol. 81 (1-2), 131-143. 
Ortuño, M.F., Conejero, W., Moreno, F., Moriana, A., Intrigliolo, D.S., Biel, C., Mellisho, C.D., Pérez-Pastor, A., Domingo, R., Ruiz-Sánchez, M.C., Casadesus, J., Bonany, J., Torrecillas, A., 2010. Could trunk diameter sensors be used in woody crops for irrigation scheduling? A review of current knowledge and future perspectives. Agric. Water Manage. 97 (1), 1-11.

Ovando, G., de la Casa, A., Rodríguez, A., Accietto, R., Bressanini, L., 1999. Determinación fotogramétrica del área foliar en papa usando una técnica estándar de interpretación de imágenes de satélites. In XI Congresso Brasileiro de Agrometeorologia y II Reunião Latino Americana de Agrometeorologia, Florianópolis, Brasil. Soc. Bras. de Agrometeorologia (pp. 121-127).

Panigrahi, B., Panda, S.N., 2003. Field test of a soil water balance simulation model. Agric. Water Manage. 58 (3), 223-240.

Papadakis, J., 1966. Climates of the world and their agricultural potentialities, Buenos Aires, pp. 174.

Payero, J.O., Neale, C.M.U., Wright, J.L., Allen, R.G., 2003. Guidelines for validating Bowen ratio data. Trans. ASAE 46 (4), 1051-1060.

Peake, C., Riveros-Iregui, D., Lenters, J., Zlotnik, V., Ong, J., 2013. Environmental and groundwater controls on evaporation rates of a shallow saline lake in the western Sandhills Nebraska, USA. In: AGU Fall Meeting Abstracts, Western Sand-hills, NE, USA, p. 1469, 1.

Penman, H.L., 1948. Natural evaporation from open water, bare soil and grass. Proc. R. Soc. London., Ser. A 193 (1032), 120-145.

Pereira, L.S., Perrier, A., Allen, R.G., Alves, I., 1999. Evapotranspiration: concepts and future trends. J. Irrig. Drain. Eng. 125 (5), 235-245 (ASCE).

Pérez, P.J., Castellví, F., 2002. Análisis de la evapotranspiración a escala local y regional en Cataluña. Ingeniería del agua 9 (1), 59-72.

Pérez, P.J., Castellví, F., Ibáñez, M., Rosell, J.I., 1999. Assessment of reliability of Bowen ratio method for partitioning fluxes. Agric. For. Meteorol. 97 (3), 141-150. 
Potter, B., Lenters, J., Hinkel, K., Shulski, M., Healey, N., Irmak, A., Jones, S., Sheng, Y., 2011. The summertime energy balance of a thermokarst lake in northern Alaska: a three-year study of seasonal and interannual variability. AGU Fall Meeting Abstracts 1, 08.

Priestley, C.H.B., Taylor, R.J., 1972. On the assessment of surface heat flux and evaporation using large-scale parameters. Mon. Weather Rev. 100, 81-92.

Prueger, J.H., Hatfield, J.L., Aase, J.K., Pikul Jr., J.L., 1997. Bowen-ratio comparisons with lysimeter evapotranspiration. Agron. J. 89 (5), 730-736.

Pruitt, W.O., Lourence, F.J., 1985. Experiences in lysimetry for ET and surface drag measurements. Advances in Evapotranspiration, 74. American Society of Agricultural Engineers, St. Joseph, MI, USA, pp. 51-69, 85.

Purcell, L.C., 2000. Soybean canopy coverage and light interception measurements using digital imagery. Crop Sci. 40, 834-837.

Rana, G., Losavio, N., Mastrorilli, M., Scarascia, M.E.V., 1990. Crop evapotranspiration measured by two energy balance methods under mediterranean climate. Acta Hortic. 278, 517-524.

Rana, G., Katerji, N., Mastrorilli, M., El Moujabber, M., 1994. Evapotranspiration and canopy resistance of grass in a Mediterranean region. Theor. Appl. Climatol. 50, $61-71$.

Rana, G., Katerji, N., 2000. Measurement and estimation of actual evapotranspiration in the field under mediterranean climate: a review. Eur. J. Agron. 13, 125-153.

Richardson, M., Karcher, D., Purcell, L., 2001. Quantifying turfgrass cover using digital image analysis. Crop Sci. 41, 1884-1888.

Rincón, L., Balsalobre, E., Sáez, J., Madrid, R., 1991. Extracción de macronutrientes en cultivo de lechuga iceberg. In: II Congreso Nacional de Fertirrigación. FIAPASECH, Almería, pp. 213-220.

Rincón, L., Sáez, J., 1997. Determinación de la evapotranspiración y de los coeficientes de cultivo de la lechuga Iceberg con riego por goteo. Acta Hort. (ISHS) 19, 193201. 
Rincón, L., 2001. Necesidades hídricas, absorción de nutrientes y respuesta a la fertilización nitrogenada de la lechuga iceberg. Universidad de Murcia, Murcia, Tesis Doctoral.

Rincón, L., 2005. La fertirrigación de la lechuga iceberg. Instituto Murciano de Investigación y Desarrollo Agrario y Alimentario, Murcia.

Rodríguez, A., de la Casa, A., Accietto, R., Bressanini, L., Ovando, G., 2000. Determinación del área foliar en papa (Solanum tuberosum L. var. Spunta) por medio de fotografías digitales conociendo la relación entre el número de píxeles y la altura de adquisición. Rev. Bras. Agrometeorol. 8, 215-221.

Rosenberg, N.J., Blad, B.L., Verma, S.B., 1983. Microclimate: The Biological Environment, second ed. John Wiley, New York, NY.

Salter, P.J., Goode, J.E., 1967. Crop Responses to Water at Different Stages of Growth. Commonwealth Agricultural Bureaux, England.

Sammis, T., Sharma, P., Shukla, M., Wang, J., Miller, D., 2012. A water-balance dripirrigation scheduling model. Agric. Water Manage. 113, 30-37.

Savage, M.J., 2010. Field evaluation of polymer capacitive humidity sensors for Bowen ratio energy balance flux measurements. Sensors 10 (8), 7748-7771.

Savage, M.J., Everson, C.S., Metelerkamp, B.R., 2009. Bowen ratio evaporation measurement in a remote montane grassland: data integrity and fluxes. J. Hydrol. 376 (1-2), 249-260.

Saxton, K.E., Rawls, W.J., 2006. Soil water characteristic estimates by texture and organic matter for hydrologic solutions. Soil Sci. Soc. Am. J. 70, 1569-1578.

Shang, S., Mao, X., 2006. Application of a simulation based optimization model for winter wheat irrigation scheduling in North China. Agric. Water Manage. 85 (3), $314-322$.

Shaw, R., Snyder, R.L., Medawar, C.K., Phene, C.J., 2003. Evaporation and eddy correlation. In: Encyclopedia of Water Science. Marcel Dekker, Inc., New York, NY, pp. 235-237.

Shih, P., Liu, C., 2005. Comparative assessment of content-based face image retrieval in different color spaces. Int. J. Patt. Recogn. Artif. Intell. 19 (7), 873-893. 
Sonneveld, C., Mook, E., 1983. Lettuce tip burn as related to the cation contents of different plant parts. Plant Soil. 75 (1), 29-40.

Steduto, P., Caliandro, A., Rubino, P., Ben Mechlia, N., Masmoudi, M., MartínezCob,A., Faci, J.M., Rana, G., Mastrorilli, M., El Mourid, M., Karrou, M., Kanber, R.,Kirda, C., El-Quosy, D., El-Askari, K., Ait Ali, M., Zareb, D., Snyder, R.L., 1996. Penman-Monteith reference evapotranspiration estimates in the Mediterranean region. In: Camp, C.R., Sadler, E.J., Yoder, R.E. (Eds.), Proc. Int. Conf. On Evapotranspiration and Irrig. Scheduling. San Antonio, TX, USA, pp. $357-364$.

Steduto, P., Hsiao, T.C., Raes, D., Fereres, E., 2009. AquaCrop - the FAO crop model to simulate yield response to water: I. Concepts and underlying principles. Agron. J. 101, 426-437.

Stöckle, C.O., Donatelli, M., Nelson, R., 2003. CropSyst, a cropping systems simulation model. Eur. J. Agron. 18, 289-307.

Story, D., Kacira, M., Kubota, C., Akoglu, A., An, L. L., 2010. Lettuce calcium deficiency detection with machine vision computed plant features in controlled environments. Comput. Electron. Agr. 74 (2), 238-243.

Sutton, B., Merit, N., 1993. Maintenance of lettuce root zone at field capacity gives best yields with drip irrigation. Sci. Hortic. Amsterdam 56, 1-11.

Taylor, H., Brar, G., 1991. Effect of soil compaction on root development. Soil Till. Res. $19,111-119$.

Terrillon, J.C., Akamatsu, S., 2000. Comparative performance of different chrominance spaces for color segmentation and detection of human faces in complex scene images. In: International Conf. on Face and Gesture Recognition, pp. 54-61.

Thornthwaite, C.W., 1948. An approach toward a rational classification of climate. Geogr. Rev. 38, 55-94.

Todd, R.W., Evett, S.R., Howell, T.A., 2000. The Bowen ratio-energy balance method for estimating latent heat flux of irrigated alfalfa evaluated in a semi-arid, advective environment. Agric. For. Meteorol. 103, 335-348.

Todorovic, M., 1999. Single-layer evapotranspiration model with variable canopy resistance. J. Irrig. Drain. Eng. 125 (5), 235-245. 
Tolk, J.A., Evett, S.R., Howell, T.A., 2006. Advection influences on evapotranspiration of alfalfa in a semiarid climate. Agron. J. 98 (6), 1646-1654.

Uddin, J., Hancock, N.H., Smith, R.J., Foley, J.P., 2013. Measurement of evapotranspiration during sprinkler irrigation using a precision energy budget (Bowen ratio, eddy covariance) methodology. Agric. Water Manage. 116, 89-100.

Unland, H.E., Houser, P.R., Shuttleworth, W.J., Yang, Z.L., 1996. Surface flux measurement and modeling at a semi-arid Sonoran Desert site. Agric. For. Meteorol. 82 (1-4), 119-153.

Unlu, M., Kanber, R., Kapur, B., 2010. Comparison of soybean evapotranspirations measured by weighing lysimeter and Bowen ratio-energy balance methods. Afr. J. Biotechnol. 9 (30), 4700-4713.

Ventura, F., Spano, D., Duce, P., Snyder, R.L., 1999. An evaluation of common evapotranspiration equations. Irrig. Sci. 18 (4), 163-170.

Walthall, C., Dulaney, W., Anderson, M., Norman, J., Fang, H., Liang, S., 2004. A comparison of empirical and neural network approaches for estimating corn and soybean leaf area index from Landsat ETM+ imagery. Remote Sens. Environ. 92, $465-474$.

Watson, D. J., 1947. Comparative physiological studies on the growth of field crops: I. Variation in net assimilation rate and leaf area between species and varieties, and within and between years. Ann. Bot. 11 (1), 41-76.

Whisler, F.D., Acock, B., Baker, D.N., Fye, R.E., Hodges, H.F., Lambert, J.R., 1986. Crop simulation models in agronomic systems. Adv. Agron. 40, 141-208.

Willmott, C.J., 1982. Some comments on the evaluation of model performance. Bull. Am. Meteorol. Soc. 63 (11), 1309-1313.

Wright, J.L., 1981. Crop Coefficients. Irrig. Scheduling for Water and Energy Conserv. in the 80's, Chicago. American Society of Agricultural Engineers, St. Joseph, MI, pp. 18-26.

Wright, J.L., 1982. New evapotranspiration crop coefficients. J. Irrig. Drain. Div., ASCE108 (IR2), 57-74. 
Xiang, H.T., Tian, L., 2011. Method for automatic georeferencing aerial remote sensing (RS) images from an unmanned aerial vehicle (UAV) platform. Biosyst. Eng. 108 (2), 104-113.

Xiao, L., Tingfangzi, T., Suiliang, H., Yang, L., 2011. Image processing based nondestructive method for measuring growth of constructed wetland plants. In: Proc. 5th iCBBE, pp. 1-4.

Xing, Z.S., Chow, L., Meng, F.R., Rees, H.W., Stevens, L., Monteith, J., 2008. Validating evapotranspiration equations using Bowen Ratio in New Brunswick, Maritime. Can. Sensors 8 (1), 412-428.

Xu, X.G., Wang, J.H., Li, C.J., Song, X.U., Huang, W.J., 2010. Estimating growth height of winter wheat with remote sensing. In: Proc. SPIE 7824, Remote Sensing for Agriculture, Ecosystems, and Hydrology, vol. XII, p. 782428.

Zeggaf, A.T., Takeuchi, S., Dehghanisanij, H., Anyoji, H., Yano, T., 2008. A Bowen ratio technique for partitioning energy fluxes between maize transpiration and soil surface evaporation. Agron. J. 100 (4), 988-996.

Zhang, C., Kovacs, J.M., 2012. The application of small unmanned aerial systems for precision agriculture: a review. Precis. Agric. 13, 693-712. 
Apéndice I

NOTIFICACIONES DE ACEPTACIÓN DE LAS PUBLICACIONES 



\section{Publicación 1}

$\begin{array}{ll}\text { De: } & \text { ees.agwat.0.2c9fb5.cca224f9@eesmail.elsevier.com } \\ & \text { [mailto:ees.agwat.0.2c9fb5.cca224f9@eesmail.elsevier.com] } \\ & \text { en nombre de Agricultural Water Management } \\ \text { Enviado el: } & \text { miércoles, 10 de septiembre de 2014 9:28 } \\ \text { Para: } & \text { david.escarabajal@gmail.com } \\ \text { CC: } & \text { david.escarabajal@outlook.es; eagledang@gmail.com } \\ \text { Asunto: } & \text { Your Submission }\end{array}$

\section{Ref.: Ms. No. AGWAT6317R1}

Selection of device to determine temperature gradients for estimating evapotranspiration using energy balance method Agricultural Water Management

Dear Mr. Escarabajal-Henarejos,

I am pleased to tell you that your work has now been accepted for publication in Agricultural Water Management. The manuscript will be transferred to our production site for preparation for press. I will be your contact person during the production process of the paper towards the final publication on the web (Science Direct) and on paper (in the printed-on-paper issue).

Proofs will be sent to you in due course.

If there were any comments from the Editor and/or Reviewers, they can be found below.

When your paper is published on ScienceDirect, you want to make sure it gets the attention it deserves. To help you get your message across, Elsevier has developed a new, free service called AudioSlides: brief, webcast-style presentations that are shown (publicly available) next to your published article. This format gives you the opportunity to explain your research in your own words and attract interest. You will receive an invitation email to create an AudioSlides presentation shortly. For more information and examples, please visit http://www.elsevier.com/audioslides.

Thank you for submitting your work to this journal.

With kind regards,

Pallavi Das

Agricultural Water Management

agwat@elsevier.com 


\section{Publicación 2}

De: ees.ybeng.16a4.22d31a.43705501@eesmail.elsevier.com en nombre de Guest Editors Image Analysis in Agriculture

<blasco_josiva@gva.es>

Enviado el: $\quad$ sábado, 27 de julio de 2013 12:31

Para: $\quad$ eagledang@gmail.com

CC:_blasco_josiva@gva.es; naleixos@labdesign.i3bh.es; molto@ivia.es

Asunto: Your Submission

\section{Ms. Ref. No.: YBENG-D-12-00585R2}

Title: A digital image processing-based method for determining the crop coefficient of lettuce crops in the southeast of Spain Biosystems Engineering

Dear Dr. Daniel G. Fernandez-Pacheco,

I am pleased to inform you that your paper "A digital image processing-based method for determining the crop coefficient of lettuce crops in the southeast of Spain" has been accepted for publication in Biosystems Engineering.

Below are comments from the Managing Editor incorporating some comments of the Guest Editors.

When your paper is published on ScienceDirect, you want to make sure it gets the attention it deserves. To help you get your message across, Elsevier has developed a new, free service called AudioSlides: brief, webcast-style presentations that are shown (publicly available) next to your published article. This format gives you the opportunity to explain your research in your own words and attract interest. You will receive an invitation email to create an AudioSlides presentation shortly. For more information and examples, please visit http://www.elsevier.com/audioslides.

Thank you for submitting your work to Biosystems Engineering.

Yours sincerely,

Steve Parkin, Phd, CEng, CEnv, FIAgrE

Managing Editor

Biosystems Engineering 


\section{Publicación 3}

$\begin{array}{ll}\text { De: } & \text { ees.agwat.0.2c9fb5.cca224f9@eesmail.elsevier.com } \\ & \text { [mailto:ees.agwat.0.2c9fb5.cca224f9@eesmail.elsevier.com] } \\ & \text { en nombre de Agricultural Water Management } \\ \text { Enviado el: } & \text { lunes, 5 de agosto de 2014 5:37 } \\ \text { Para: } & \text { david.escarabajal@gmail.com } \\ \text { CC: } & \text { david.escarabajal@outlook.es; eagledang@gmail.com } \\ \text { Asunto: } & \text { Your Submission }\end{array}$

Ref.: Ms. No. AGWAT6414R2

Digital photography applied to irrigation management of Little Gem lettuce Agricultural Water Management

Dear Mr. Escarabajal-Henarejos,

I am pleased to tell you that your work has now been accepted for publication in Agricultural Water Management. The manuscript will be transferred to our production site for preparation for press. I will be your contact person during the production process of the paper towards the final publication on the web (Science Direct) and on paper (in the printed-on-paper issue).

Proofs will be sent to you in due course.

If there were any comments from the Editor and/or Reviewers, they can be found below.

When your paper is published on ScienceDirect, you want to make sure it gets the attention it deserves. To help you get your message across, Elsevier has developed a new, free service called AudioSlides: brief, webcast-style presentations that are shown (publicly available) next to your published article. This format gives you the opportunity to explain your research in your own words and attract interest. You will receive an invitation email to create an AudioSlides presentation shortly. For more information and examples, please visit http://www.elsevier.com/audioslides.

Thank you for submitting your work to this journal.

With kind regards,

Pallavi Das

Agricultural Water Management

agwat@elsevier.com 


\section{Publicación 4}

De: ees.agwat.0.2c9fb5.cca224f9@eesmail.elsevier.com

[mailto:ees.agwat.0.2c9fb5.cca224f9@eesmail.elsevier.com]

en nombre de Agricultural Water Management

Enviado el: jueves, 16 de octubre de 2014 11:54

Para: david.escarabajal@gmail.com

CC: david.escarabajal@outlook.es; eagledang@gmail.com

Asunto: $\quad$ Your Submission

\section{Ref.: Ms. No. AGWAT6398R1}

Methodology for obtaining prediction models of the root depth of lettuce for its application in irrigation automation Agricultural Water Management

Dear Mr. Escarabajal-Henarejos,

I am pleased to tell you that your work has now been accepted for publication in Agricultural Water Management. The manuscript will be transferred to our production site for preparation for press. I will be your contact person during the production process of the paper towards the final publication on the web (Science Direct) and on paper (in the printed-on-paper issue).

Proofs will be sent to you in due course.

If there were any comments from the Editor and/or Reviewers, they can be found below.

When your paper is published on ScienceDirect, you want to make sure it gets the attention it deserves. To help you get your message across, Elsevier has developed a new, free service called AudioSlides: brief, webcast-style presentations that are shown (publicly available) next to your published article. This format gives you the opportunity to explain your research in your own words and attract interest. You will receive an invitation email to create an AudioSlides presentation shortly. For more information and examples, please visit http://www.elsevier.com/audioslides.

Thank you for submitting your work to this journal.

With kind regards,

Pallavi Das

Agricultural Water Management

agwat@elsevier.com 


\section{Publicación 5}

$\begin{array}{ll}\text { De: } & \text { ees.agwat.0.2c9fb5.cca224f9@eesmail.elsevier.com } \\ & \text { [mailto:ees.agwat.0.2c9fb5.cca224f9@eesmail.elsevier.com] } \\ & \text { en nombre de Agricultural Water Management } \\ \text { Enviado el: } & \text { lunes, 1 de septiembre de 2014 14:57 } \\ \text { Para: } & \text { ginesgm@um.es } \\ \text { CC: } & \\ \text { Asunto: } & \text { Your Submission }\end{array}$

Ref.: Ms. No. AGWAT6357R2

Study and comparison of color models for automatic image analysis in irrigation management applications Agricultural Water Management

Dear Dr. Garcia-Mateos,

I am pleased to tell you that your work has now been accepted for publication in Agricultural Water Management. The manuscript will be transferred to our production site for preparation for press. I will be your contact person during the production process of the paper towards the final publication on the web (Science Direct) and on paper (in the printed-on-paper issue).

Proofs will be sent to you in due course.

If there were any comments from the Editor and/or Reviewers, they can be found below.

When your paper is published on ScienceDirect, you want to make sure it gets the attention it deserves. To help you get your message across, Elsevier has developed a new, free service called AudioSlides: brief, webcast-style presentations that are shown (publicly available) next to your published article. This format gives you the opportunity to explain your research in your own words and attract interest. You will receive an invitation email to create an AudioSlides presentation shortly. For more information and examples, please visit http://www.elsevier.com/audioslides.

Thank you for submitting your work to this journal.

With kind regards,

Pallavi Das

Agricultural Water Management

agwat@elsevier.com 

Apéndice II

\section{ÍNDICES DE IMPACTO DE LAS PUBLICACIONES}



- Publicación 1: Escarabajal-Henarejos, D., Fernández-Pacheco, D.G., MolinaMartínez, J.M., Martínez-Molina, L., Ruiz-Canales, A., 2014. Selection of device to determine temperature gradients for estimating evapotranspiration using energy balance method. Agricultural Water Management; In press.

IF (Agr. Water Manage.): 2,333

- Publicación 2: Fernández-Pacheco, D.G., Escarabajal-Henarejos, D., RuizCanales, A., Conesa, J., Molina-Martínez, J.M., 2014. A digital image-processingbased method for determining the crop coefficient of lettuce crops in the southeast of Spain. Biosystems Engineering; 117, 23 - 34.

IF (Biosyst. Eng.): 1,367

- Publicación 3: Escarabajal-Henarejos, D., Molina-Martínez, J.M., FernándezPacheco, D.G., Cavas-Martínez, F., García-Mateos, G., 2014. Digital photography applied to irrigation management of Little Gem lettuce. Agricultural Water Management; In press.

IF (Agr. Water Manage.): 2,333

- Publicación 4: Escarabajal-Henarejos, D., Molina-Martínez, J.M., FernándezPacheco, D.G., García-Mateos, G., 2014. Methodology for obtaining prediction models of the root depth of lettuce for its application in irrigation automation. Agricultural Water Management; In press.

IF (Agr. Water Manage.): 2,333

- Publicación 5: García-Mateos, G., Hernández-Hernández, J.L., EscarabajalHenarejos, D., Jaén-Terrones, S., Molina-Martínez, J.M., 2014. Study and comparison of color models for automatic image analysis in irrigation management applications. Agricultural Water Management; In press.

IF (Agr. Water Manage.): 2,333

Fuente: ISI Web of Knowledge, Journal Citation Reports, 2013 JCR Science Edition. 


\section{ISI Web of Knowledge ${ }^{\mathrm{sM}}$}

\section{Journal Citation Reports ${ }^{\oplus}$}

DELLCOME ? HELP

2013 JCR Science Edition

Journal Summary List

Journal Title Changes Journals from: search Full Journal Title for 'AGRICULTURAL WATER MANAGEMENT' Sorted by: Journal Title $\quad \checkmark$ SORT AGAIN

Journals 1 - 1 (of 1)

$\mid\langle\langle\langle\langle[1]\rangle \|\rangle$

Page 1 of 1

MARK ALL UPDATE MARKED LIST Ranking is based on your journal and sort selections.

\begin{tabular}{|c|c|c|c|c|c|c|c|c|c|c|c|}
\hline \multirow[b]{2}{*}{ Mark } & \multirow[b]{2}{*}{ Rank } & \multirow{2}{*}{$\begin{array}{l}\text { Abbreviated Journal } \\
\text { Title } \\
\text { (linked to journal } \\
\text { information) }\end{array}$} & \multirow[b]{2}{*}{ ISSN } & \multicolumn{6}{|c|}{ JCR Data i) } & \multicolumn{2}{|c|}{ Eigenfactor $^{(}$Metrics i $^{-}$} \\
\hline & & & & $\begin{array}{l}\text { Total } \\
\text { Cites }\end{array}$ & $\begin{array}{c}\text { Impact } \\
\text { Factor }\end{array}$ & $\begin{array}{c}\text { 5-Year } \\
\text { Impact } \\
\text { Factor }\end{array}$ & $\begin{array}{c}\text { Immediacy } \\
\text { Index }\end{array}$ & Articles & $\begin{array}{l}\text { Cited } \\
\text { Half- } \\
\text { life }\end{array}$ & $\begin{array}{c}\text { Eigenfactor }{ }^{\circledR} \\
\text { Score }\end{array}$ & $\begin{array}{c}\text { Article } \\
\text { Influence } \\
\text { Score }\end{array}$ \\
\hline$\square$ & 1 & AGR WATER MANAGE & $\begin{array}{l}0378- \\
3774\end{array}$ & 6671 & 2.333 & 2.822 & 0.389 & 221 & 6.7 & 0.01201 & 0.720 \\
\hline
\end{tabular}

MARK ALL UPDATE MARKED LIST

Journals 1 - 1 (of 1) 


\section{ISI Web of Knowledge ${ }^{\text {sM }}$}

\section{Journal Citation Reports ${ }^{\oplus}$}

\begin{tabular}{|c|c|c|}
\hline WELCOME & ? HELP & \\
\hline
\end{tabular}

2013 JCR Science Edition

\section{Rank in Category: AGRICULTURAL WATER MANAGEMENT}

\section{Journal Ranking i}

For 2013, the journal AGRICULTURAL WATER MANAGEMENT has an Impact Factor of $\mathbf{2 . 3 3 3}$.

This table shows the ranking of this journal in its subject categories based on Impact Factor.

\begin{tabular}{|l|c|c|c|}
\hline Category Name & $\begin{array}{c}\text { Total Journals } \\
\text { in Category }\end{array}$ & $\begin{array}{c}\text { Journal Rank } \\
\text { in Category }\end{array}$ & $\begin{array}{c}\text { Quartile } \\
\text { in Category }\end{array}$ \\
\hline AGRONOMY & 78 & 16 & Q1 \\
\hline WATER RESOURCES & 79 & 18 & Q1 \\
\hline
\end{tabular}

\section{Category Box Plot i)}

For 2013, the journal AGRICULTURAL WATER MANAGEMENT has an Impact Factor of $\mathbf{2 . 3 3 3 .}$

This is a box plot of the subject category or categories to which the journal has been assigned. It provides information about the distribution of journals based on Impact Factor values. It shows median, 25th and 75th percentiles, and the extreme values of the distribution.

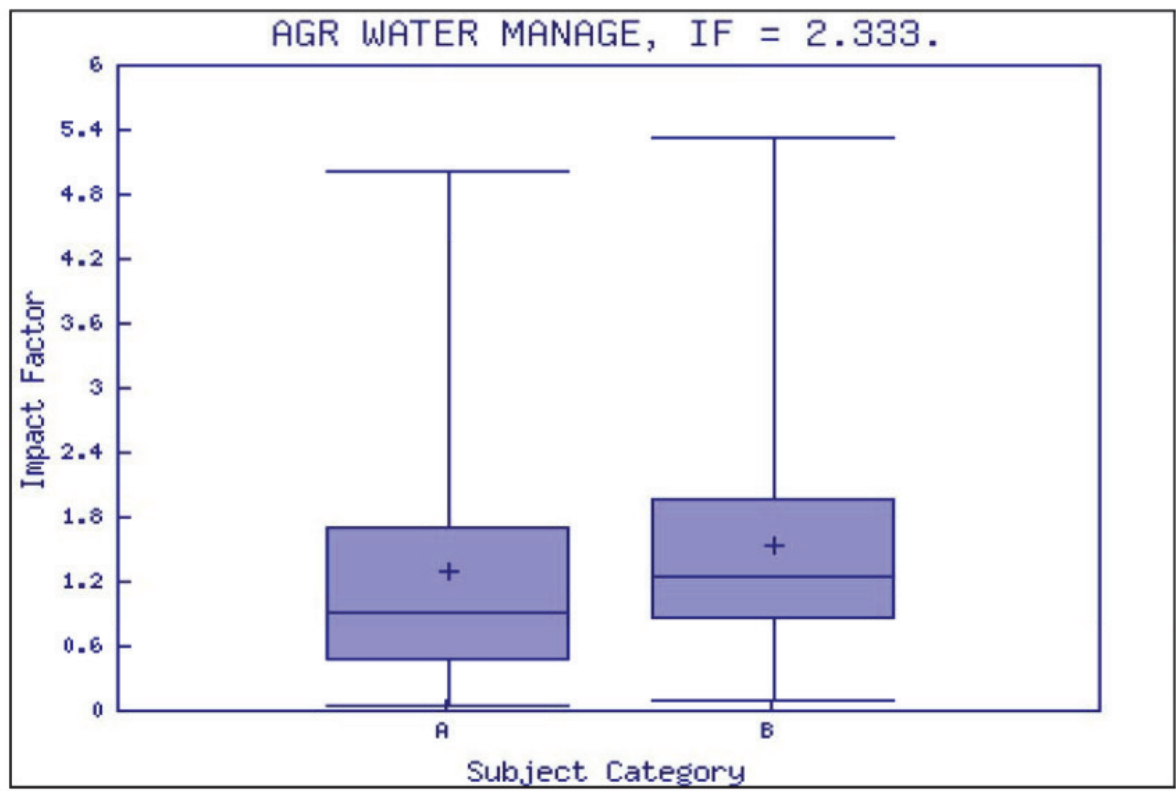

Key

A - AGRONOMY

B - WATER

RESOURCES 


\section{ISI Web of Knowledge ${ }^{\text {SM }}$}

\section{Journal Citation Reports ${ }^{\oplus}$}

\section{Journal Summary List}

Journal Title Changes Journals from: search Full Journal Title for 'BIOSYSTEMS ENGINEERING '

Sorted by:

Journal Title $\checkmark$ SORT AGAIN

Journals 1 - 1 (of 1 )

$\mid\langle\langle\langle[1]\rangle \geqslant|$

Page 1 of 1

MARK ALL UPDATE MARKED LIST Ranking is based on your journal and sort selections.

\begin{tabular}{|c|c|c|c|c|c|c|c|c|c|c|c|}
\hline \multirow[b]{2}{*}{ Mark } & \multirow[b]{2}{*}{ Rank } & \multirow{2}{*}{$\begin{array}{c}\text { Abbreviated } \\
\text { Journal Title } \\
\text { (linked to } \\
\text { journal } \\
\text { information) }\end{array}$} & \multirow[b]{2}{*}{ ISSN } & \multicolumn{6}{|c|}{ JCR Data i) } & \multicolumn{2}{|c|}{ Eigenfactor $^{\circledR}$ Metrics i) } \\
\hline & & & & \begin{tabular}{|l|} 
Total \\
Cites
\end{tabular} & $\begin{array}{c}\text { Impact } \\
\text { Factor }\end{array}$ & $\begin{array}{l}\text { 5-Year } \\
\text { Impact } \\
\text { Factor }\end{array}$ & $\begin{array}{c}\text { Immediacy } \\
\text { Index }\end{array}$ & Articles & \begin{tabular}{|c|} 
Cited \\
Half- \\
life
\end{tabular} & $\begin{array}{c}\text { Eigenfactor }{ }^{\circledR} \\
\text { Score }\end{array}$ & $\begin{array}{c}\text { Article } \\
\text { Influence } \\
\text { Score }\end{array}$ \\
\hline$\square$ & 1 & BIOSYST ENG & $\begin{array}{l}1537- \\
5110\end{array}$ & 2945 & 1.367 & 1.727 & 0.365 & 148 & 6.4 & 0.00561 & 0.443 \\
\hline
\end{tabular}

MARK ALL UPDATE MARKED LIST

Journals 1 - 1 (of 1 ) 


\section{ISI Web of Knowledge ${ }^{\mathrm{sM}}$}

\section{Journal Citation Reports ${ }^{\oplus}$}

\begin{tabular}{|c|c|}
\hline WELCOME & ? HELP \\
\hline
\end{tabular}

\section{Rank in Category: BIOSYSTEMS ENGINEERING}

\section{Journal Ranking i}

For 2013, the journal BIOSYSTEMS ENGINEERING has an Impact Factor of 1.367.

This table shows the ranking of this journal in its subject categories based on Impact Factor.

\begin{tabular}{|l|c|c|c|}
\hline \multicolumn{1}{|c|}{ Category Name } & $\begin{array}{c}\text { Total Journals } \\
\text { in Category }\end{array}$ & $\begin{array}{c}\text { Journal Rank } \\
\text { in Category }\end{array}$ & $\begin{array}{c}\text { Quartile } \\
\text { in Category }\end{array}$ \\
\hline AGRICULTURAL ENGINEERING & 12 & 4 & Q2 \\
\hline AGRICULTURE, MULTIDISCIPLINARY & 56 & 11 & Q1 \\
\hline
\end{tabular}

\section{Category Box Plot i}

For 2013, the journal BIOSYSTEMS ENGINEERING has an Impact Factor of $\mathbf{1 . 3 6 7 .}$

This is a box plot of the subject category or categories to which the journal has been assigned. It provides information about the distribution of journals based on Impact Factor values. It shows median, 25th and 75th percentiles, and the extreme values of the distribution.

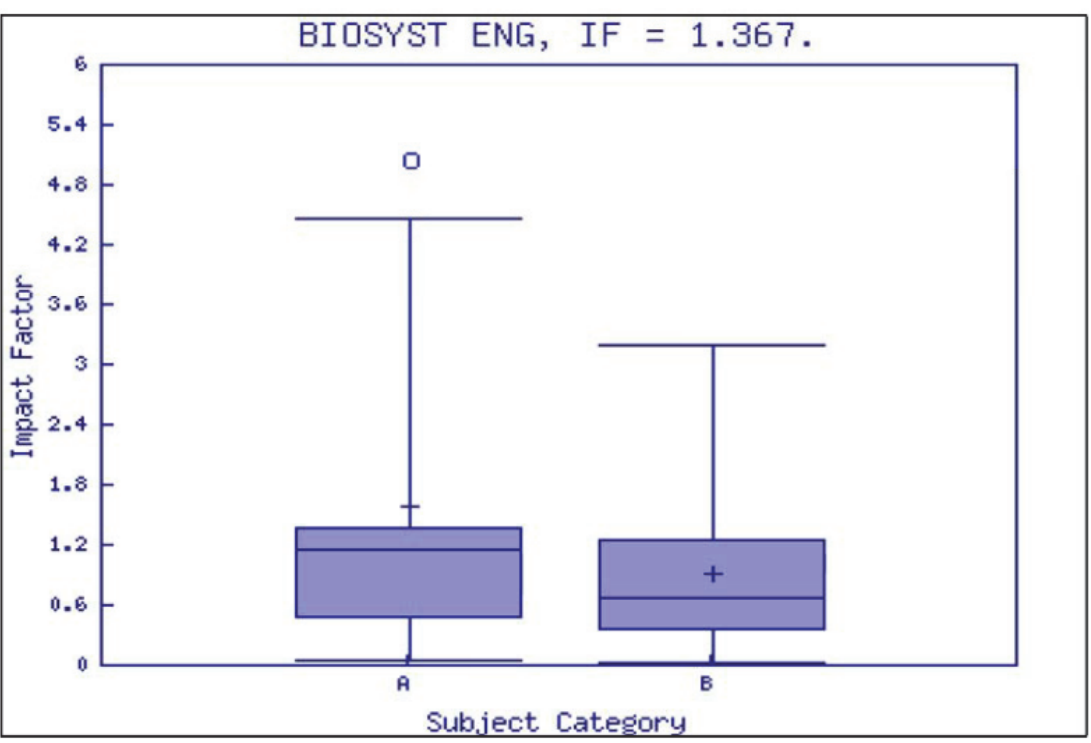

Key

A - AGRICULTURAL

ENGINEERING

AGRICULTURE,

MULTIDISCIPLINARY 
